FELIPE IBAÑEZ DE SANTI FERRARA

\title{
INFLUÊNCIA DO TIPO DE ADUBAÇÃO NA PRODUÇAO DE AMINOÁCIDOS E DE ÁCIDO INDOL-3-ACÉTICO, ETILENO E POLIAMINAS POR BACTÉRIAS FIXADORAS DE NITROGÊNIO ISOLADAS DE CANA-DE-AÇÚCAR (SACCHARUM SP.)
}

Tese apresentada ao Programa de PósGraduação em Microbiologia do Instituto de Ciências Biomédicas da Universidade de São Paulo, para obtenção do Título de Doutor em Ciências. 
FELIPE IBAÑEZ DE SANTI FERRARA

\section{INFLUÊNCIA DO TIPO DE ADUBAÇÃO NA PRODUÇÃO DE AMINOÁCIDOS E DE ÁCIDO INDOL-3-ACÉTICO, ETILENO E POLIAMINAS POR BACTÉRIAS FIXADORAS DE NITROGÊNIO ISOLADAS DE CANA-DE-AÇÚCAR (SACCHARUM SP.)}

Tese apresentada ao Programa de Pós-Graduação em Microbiologia do Instituto de Ciências Biomédicas da Universidade de São Paulo, para obtenção do Título de Doutor em Ciências.

Área de concentração: Microbiologia de Solos

Orientadora: Prof ${ }^{a}$. Dr ${ }^{a}$. Heloiza Ramos Barbosa Co-orientadora: Prof ${ }^{a}$. Dra ${ }^{a}$. Eny lochevet Segal Floh 
Aos meus avós, Rosa e José, que não viveram para presenciar esse momento 


\section{AGRADECIMENTOS}

À professora Heloiza pelo ensinamento, amizade e paciência durante todos esses anos.

À meus pais e irmão pelo apoio, compreensão e incentivo, $\mathrm{Si}$, pela presença, apoio e ajuda em todos os momentos e o resto da minha família pela torcida e incentivo.

Ao professor Crodowaldo Pavan pela convivência e pelo exemplo.

À Iris "R2" Takako por toda a ajuda, mais do que necessária.

À todos os que trabalham ou passaram pelo laboratório e que de alguma forma ajudaram: Ricardo, Daniela Thuler, Claudia Liba, Mariana Toledo, Ligia, Cilene, João, Gustavo, Hernan, Ro, Drika, Mari, Lina, Carol, Tânia e Leonor

Aos professores Eny, Márcia, Ariel, Carlos Alberto e Beny pela ajuda e por cederem espaço, equipamentos e material.

Aos alunos e funcionários de outros laboratorios que se envolveram de alguma forma com este trabalho: Adriana, Vanildo, Claudete, Leo, Amanda, Carminha, Patrícia, Vinicius, Jean, Fernanda, Luiz, Gerson, Meire, Helô, Marlene, Marco Antônio e Zé.

Aos funcionários das secretarias: Alice, Aninha e Naíde.

À Maria e seu Idário, por me alimentarem, muitas vezes fiado...

E à FAPESP pelo financiamento deste projeto.

Muito Obrigado!!!!! 
"Dentro de cada um de nós há uma coisa que não tem nome, essa coisa é o que somos"

José Saramago 


\section{RESUMO}

FERRARA, F. I. S. Influência do tipo de adubação na produção de aminoácidos e de ácido indol-3-acético, etileno e poliaminas por bactérias fixadoras de nitrogênio isoladas de canade açúcar (Saccharum sp.). 2010. 166 f. Tese (Doutorado em Microbiologia) - Instituto de Ciências Biomédicas, Universidade de São Paulo, São Paulo, 2010.

Para se avaliar a influência da adubação orgânica, a que foi submetida cana-de-açúcar, na fisiologia de bactérias diazotróficas endofíticas foram identificados e estudados 36 isolados de plantas submetidas a tratamentos orgânico e convencional ou sem tratamento (controle). Foi evidenciado predomínio da família Enterobacteriaceae (75\%). Essas bactérias foram avaliadas quanto à excreção de substâncias promotoras de crescimento vegetal (aminoácidos, poliaminas, AIA e etileno), escolhidas como indicadoras da ação do tratamento. Os resultados mostraram que foram significativamente maiores: a excreção de aminoácidos por bactérias provenientes do tratamento orgânico assim como a produção de etileno por bactérias isoladas de plantas controle. Além das 36 linhagens acima citadas, foram identificadas sete linhagens de Rhizobium por sequenciamento dos genes 16S rRNA, recA e gapA. Três dessas linhagens foram identificadas como Rhizobium trifolii, Rhizobium etli e Rhizobium hainanense. O gênero Rhizobium ainda não havia sido descrito como endofítico de cana-de-açúcar.

Palavras-chave: Cana-de-açúcar (adubação). Fixação de nitrogênio. Promotores de crescimento vegetal. Aminoácidos. Rhizobium. 


\section{ABSTRACT}

FERRARA, F. I. S. Influence of the type of fertilization on the release of amino acids and indole-3-acetic acid, ethylene and polyamines by nitrogen fixing bacteria isolated from sugarcane (Saccharum sp.). 2010. $166 \mathrm{p}$. PhD Thesis (Microbiology) - Instituto de Ciências Biomédicas, Universidade de São Paulo, São Paulo, 2010.

Aiming to evaluate the influence of the organic fertilization, applied to sugarcane, on the physiology of endophytic nitrogen-fixing bacteria, 36 isolates of plants submitted to organic and conventional fertilization or not fertilized (control) were identified and studied. Results showed that the major part of the strains belong to the Enterobacteriaceae family (75\%). The excretions of amino acids, polyamines, IAA and ethylene - substances chosen as indicators of the action of the treatment - were evaluated in the 36 strains. The release of amino acids was significantly higher in cultures of bacteria isolated from organic treated plants and the production of ethylene was produced in greater amounts by strains isolated from control plants. Seven isolates, different from the 36 tested for the release of plant growth promoters, were identified as Rhizobium strains through $16 \mathrm{~S}$ rRNA, recA and gapA sequences. Three strains were identified as Rhizobium trifolii, Rhizobium etli and Rhizobium hainanense. This genus was not described as endophytic of sugarcane previously.

Keywords: Sugarcane (fertilization). Nitrogen fixation. Plant growth promoters. Amino acidos. Rhizobium. 


\section{LISTA DE ILUSTRAÇÕES}

Figura 1 - Esquema de funcionamento da enzima nitrogenase.

Figura 2 - Esquema de síntese e utilização de AIA em plantas. 35

Figura 3 - Ciclo de Yang, responsável pela ciclagem de metionina na célula e via de síntese de etileno. .

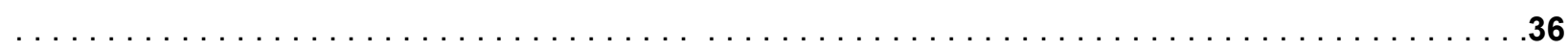

Figura 4 - Vias de síntese de poliaminas e de etileno interligadas pela S-adenosil-metionina

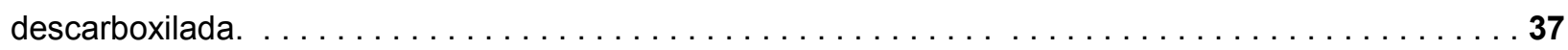

Figura 5 - Árvore filogenética construída a partir da amplificação parcial do gene 16S rRNA de 36 linhagens bacterianas endofíticas isoladas de cana-de-açúcar.

.60

Figura 6 - Árvore filogenética construída a partir da amplificação dos genes concatenados $\operatorname{rec} A$, gapA e 16S rRNA de sete linhagens bacterianas endofíticas isoladas de cana-de-açúcar pertencentes ao gênero

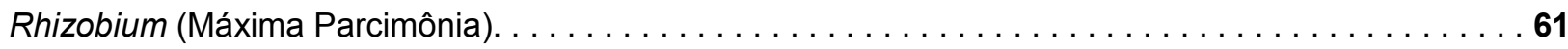

Figura 7 - Árvore filogenética construída a partir da amplificação dos genes concatenados $\operatorname{rec} A$, gapA e 16S rRNA de sete linhagens bacterianas endofíticas isoladas de cana-de-açúcar pertencentes ao gênero

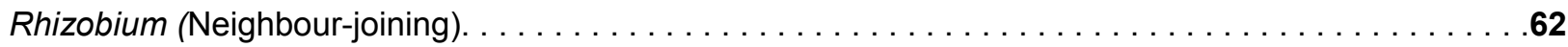

Figura 8 - Crescimento bacteriano e atividade específica da enzima nitrogenase de Herbaspirillum sp. (ICB21) em função do tempo em meio MMS. . .

Figura 9 - Crescimento bacteriano e atividade específica da enzima nitrogenase de Herbaspirillum sp. (ICB508) em função do tempo em meio MMS. .

Figura 10. Crescimento bacteriano e atividade específica da enzima nitrogenase de Herbaspirillum sp. (ICB568) em função do tempo em meio MMS.

.64

Figura 11 - Concentração de aminoácidos livres no meio ao longo do tempo em culturas de

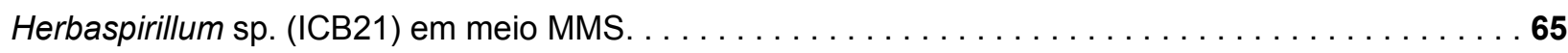

Figura 12 - Concentração de aminoácidos livres no meio ao longo do tempo em culturas de

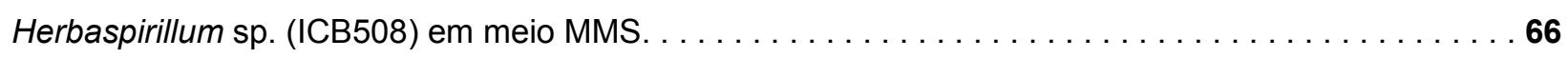


Figura 13 - Concentração de AIA livre detectada em meio MMS em função do tempo em culturas de

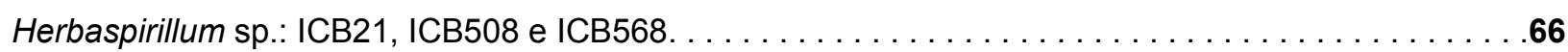

Figura 14 - Crescimento bacteriano e atividade específica da enzima nitrogenase de Enterobacter sp.

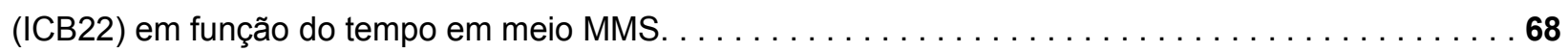

Figura 15 - Crescimento bacteriano e atividade específica da enzima nitrogenase de Enterobacter sp.

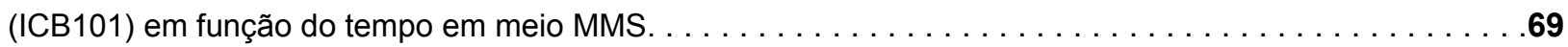

Figura 16 - Crescimento bacteriano e atividade específica da enzima nitrogenase de Enterobacter sp.

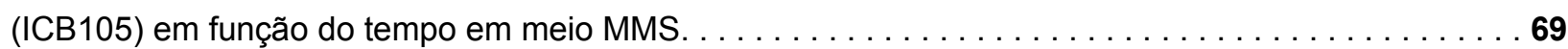

Figura 17 - Crescimento bacteriano e atividade específica da enzima nitrogenase de Enterobacter sp.

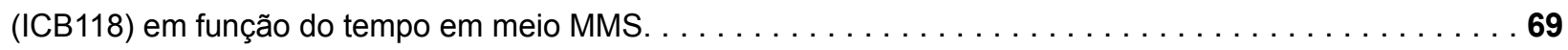

Figura 18 - Crescimento bacteriano e atividade específica da enzima nitrogenase de Enterobacter sp.

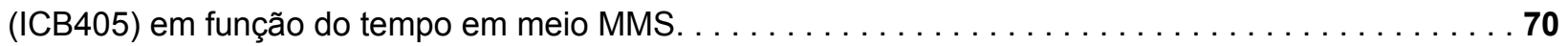

Figura 19 - Crescimento bacteriano e atividade específica da enzima nitrogenase de Enterobacter sp.

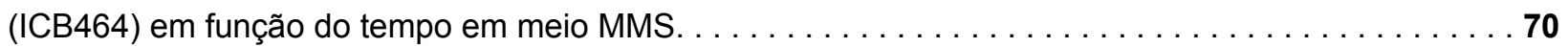

Figura 20 - Crescimento bacteriano e atividade específica da enzima nitrogenase de Enterobacter sp.

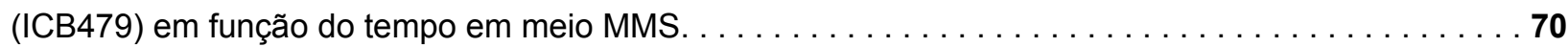

Figura 21 - Crescimento bacteriano e atividade específica da enzima nitrogenase de Enterobacter sp.

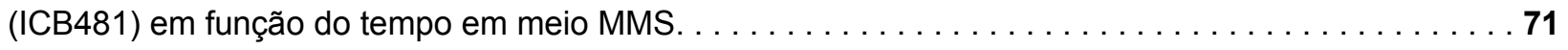

Figura 22 - Crescimento bacteriano e atividade específica da enzima nitrogenase de Enterobacter sp.

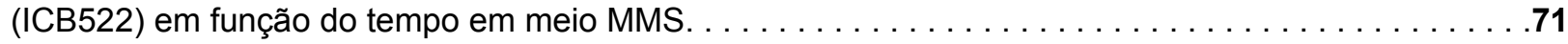

Figura 23 - Crescimento bacteriano e atividade específica da enzima nitrogenase de Enterobacter sp.

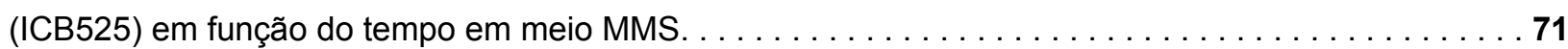

Figura 24 - Crescimento bacteriano e atividade específica da enzima nitrogenase de Enterobacter sp.

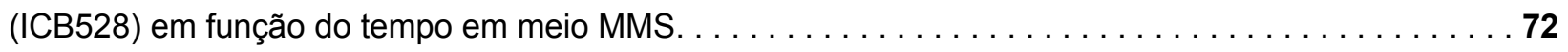

Figura 25 - Crescimento bacteriano e atividade específica da enzima nitrogenase de Enterobacter sp. 
(ICB532) em função do tempo em meio MMS.

Figura 26 - Crescimento bacteriano e atividade específica da enzima nitrogenase de Enterobacter sp. (ICB551) em função do tempo em meio MMS.

Figura 27 - Crescimento bacteriano e atividade específica da enzima nitrogenase de Enterobacter sp. (ICB561) em função do tempo em meio MMS.

Figura 28 - Crescimento bacteriano e atividade específica da enzima nitrogenase de Enterobacter sp. (ICB567) em função do tempo em meio MMS. . .

Figura 29 - Crescimento bacteriano e atividade específica da enzima nitrogenase de Enterobacter sp. (ICB569) em função do tempo em meio MMS.

Figura 30 - Crescimento bacteriano e atividade específica da enzima nitrogenase de Enterobacter sp. (ICB573) em função do tempo em meio MMS. .

Figura 31 - Concentração de aminoácidos livres no meio ao longo do tempo em culturas de Enterobacter sp. (ICB22) em meio MMS.

Figura 32 - Concentração de glicina livre no meio ao longo do tempo em culturas de Enterobacter sp. (ICB118) em meio MMS.

Figura 33 - Concentração de aspartato livre no meio ao longo do tempo em culturas de Enterobacter sp. (ICB479) em meio MMS. .76

Figura 34 - Concentração de aspartato livre no meio ao longo do tempo em culturas de Enterobacter sp. (ICB522) em meio MMS. .76

Figura 35 - Concentração de serina e glicina livres no meio ao longo do tempo em culturas de Enterobacter sp. (ICB525) em meio MMS. .77

Figura 36 - Concentração de alanina e glicina livres no meio ao longo do tempo em culturas de Enterobacter sp. (ICB567) em meio MMS. .77

Figura 37 - Concentração de putrescina e espermidina livres no meio ao longo do tempo em culturas de Enterobacter sp. (ICB101) em meio MMS. 
Figura 38 - Concentração da poliamina putrescina livre no meio ao longo do tempo em culturas de

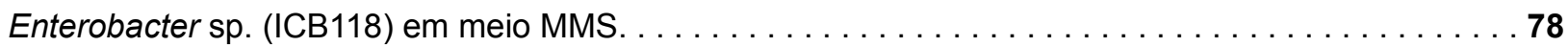

Figura 39 - Concentração da poliamina putrescina livre no meio ao longo do tempo em culturas de

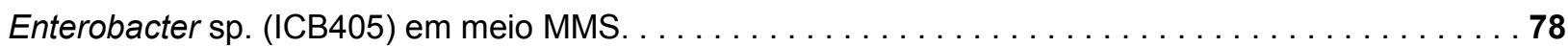

Figura 40 - Concentração de AIA livre detectada em meio MMS em função do tempo em culturas de

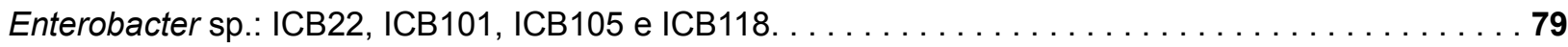

Figura 41 - Concentração de AIA livre detectada em meio MMS em função do tempo em culturas de

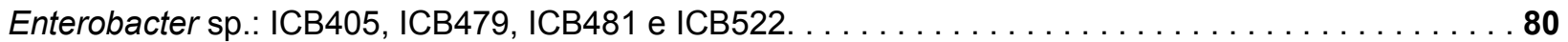

Figura 42 - Concentração de AIA livre detectada em meio MMS em função do tempo em culturas de

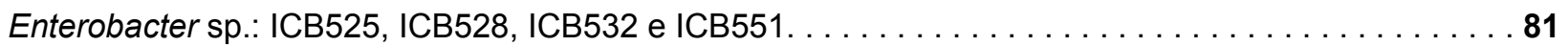

Figura 43 - Concentração de AIA livre detectada em meio MMS em função do tempo em culturas de

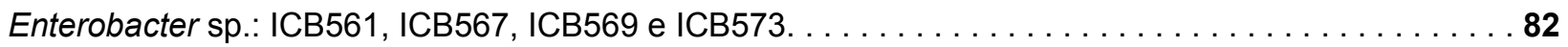

Figura 44 - Crescimento bacteriano e atividade específica da enzima nitrogenase de Klebsiella sp. (ICB115)

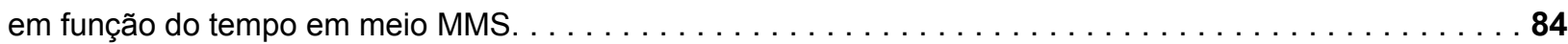

Figura 45 - Crescimento bacteriano e atividade específica da enzima nitrogenase de Klebsiella sp. (ICB365)

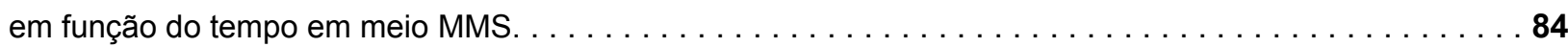

Figura 46 - Crescimento bacteriano e atividade específica da enzima nitrogenase de Klebsiella sp. (ICB369)

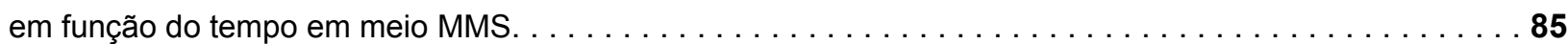

Figura 47 - Crescimento bacteriano e atividade específica da enzima nitrogenase de Klebsiella sp. (ICB375)

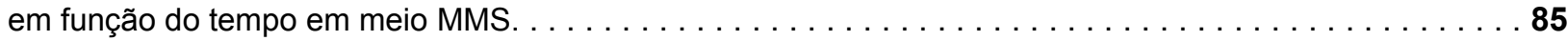

Figura 48 - Crescimento bacteriano e atividade específica da enzima nitrogenase de Klebsiella sp. (ICB439)

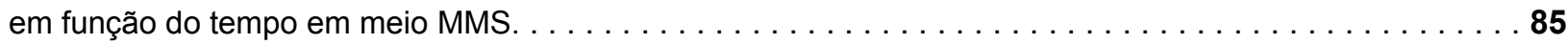

Figura 49 - Crescimento bacteriano e atividade específica da enzima nitrogenase de Klebsiella sp.

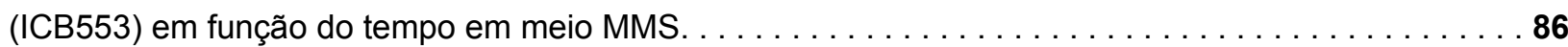


Figura 50 - Crescimento bacteriano e atividade específica da enzima nitrogenase de Klebsiella sp. (ICB565) em função do tempo em meio MMS. . . . . . . . . . . . . . . . .

Figura 51 - Crescimento bacteriano e atividade específica da enzima nitrogenase de Klebsiella sp. (ICB572)

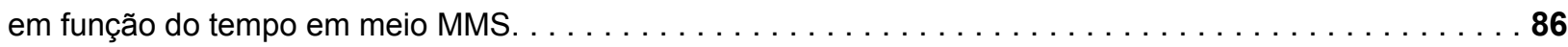

Figura 52 - Concentração de aminoácidos livres no meio ao longo do tempo em culturas de Klebsiella

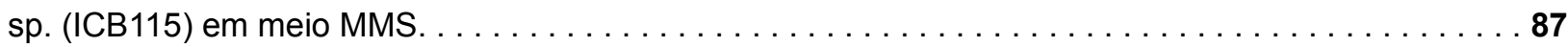

Figura 53 - Concentração de glutamato e fenilalanina livres no meio ao longo do tempo em culturas de

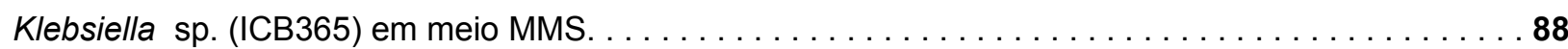

Figura 54 - Concentração de aspartato e glutamato livres no meio ao longo do tempo em culturas de

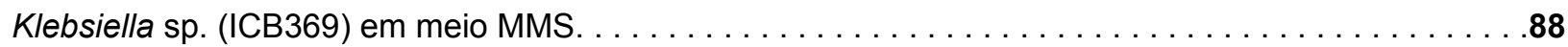

Figura 55 - Concentração de aspartato livre no meio ao longo do tempo em culturas de Klebsiella sp. (ICB375) em meio MMS.

Figura 56 - Concentração da poliamina putrescina livre no meio ao longo do tempo em culturas de

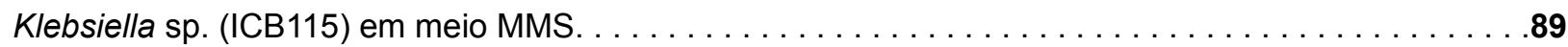

Figura 57 - Concentração da poliamina putrescina livre no meio ao longo do tempo em culturas de

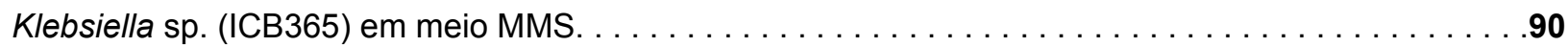

Figura 58 - Concentração da poliamina putrescina livre no meio ao longo do tempo em culturas de

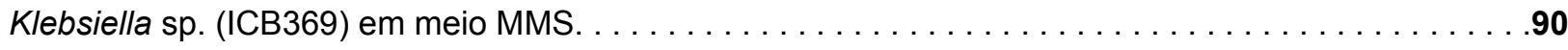

Figura 59 - Concentração da poliamina putrescina livre no meio ao longo do tempo em culturas de

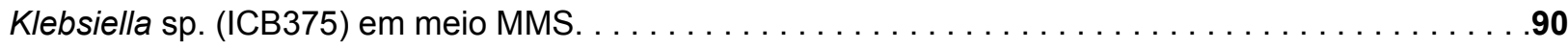

Figura 60 - Concentração de AIA livre detectada em meio MMS em função do tempo em culturas de Klebsiella sp.: ICB115, ICB365, ICB369 e ICB375. . . . . . . . . . . . . . . . . . . . . . . .91

Figura 61 - Concentração de AIA livre detectada em meio MMS em função do tempo em culturas de

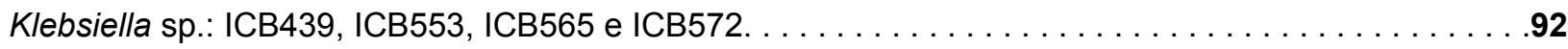

Figura 62 - Crescimento bacteriano e atividade específica da enzima nitrogenase de Acinetobacter sp. 
(ICB117) em função do tempo em meio MMS.

Figura 63 - Concentração de aminoácidos livres no meio ao longo do tempo em culturas de

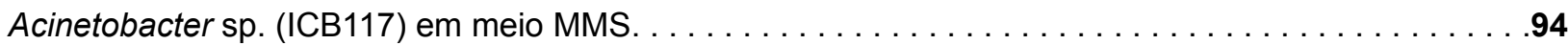

Figura 64 - Concentração da poliamina putrescina livre no meio ao longo do tempo em culturas de

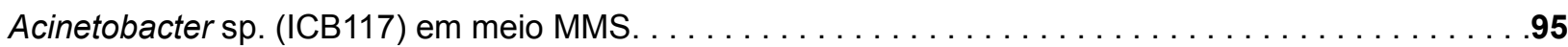

Figura 65 - Concentração de AIA livre detectada em meio MMS em função do tempo em culturas de

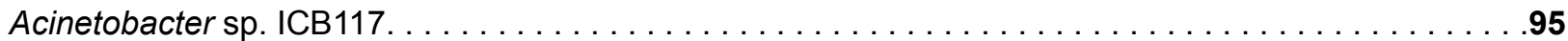

Figura 66 - Crescimento bacteriano e atividade específica da enzima nitrogenase de Pseudomonas sp. (ICB371) em função do tempo em meio MMS.

Figura 67 - Crescimento bacteriano e atividade específica da enzima nitrogenase de Pseudomonas sp. (ICB383) em função do tempo em meio MMS. .

Figura 68 - Concentração da poliamina putrescina livre no meio ao longo do tempo em culturas de Pseudomonas sp. (ICB383) em meio MMS.

Figura 69 - Concentração de AIA livre detectada em meio MMS, em função do tempo, em culturas de Pseudomonas sp. ICB383. . . . . . . . . . . . . . . . . . 98

Figura 70 - Crescimento bacteriano e atividade específica da enzima nitrogenase de Chryseobacterium sp. (ICB379) em função do tempo em meio MMS. .

Figura 71 - Concentração da poliamina putrescina livre no meio ao longo do tempo em culturas de

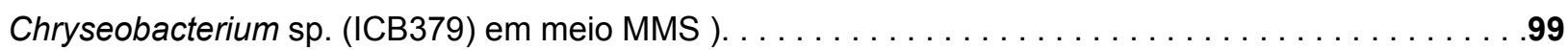

Figura 72 - Crescimento bacteriano e atividade específica da enzima nitrogenase de Rhizobium sp. (ICB386) em função do tempo em meio MMS.

Figura 73 - Concentração da poliamina putrescina livre no meio ao longo do tempo em culturas de Rhizobium sp. (ICB386) em meio MMS.

Figura 74 - Concentração de AIA livre detectada em meio MMS em função do tempo em culturas de Rhizobium sp. ICB386. 
Figura 75 - Crescimento bacteriano e atividade específica da enzima nitrogenase de Grimontella sp.

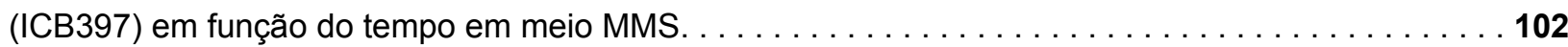

Figura 76 - Crescimento bacteriano e atividade específica da enzima nitrogenase de Grimontella sp. (ICB397) em função do tempo em meio MMS. . .

Figura 77 - Crescimento bacteriano e atividade específica da enzima nitrogenase de Erwinia sp. (ICB409) em função do tempo em meio MMS. .

Figura 78 - Concentração de AIA livre detectada em meio MMS em função do tempo em culturas de Erwinia sp. ICB409. . . . . . . . . . . . . . . . . . . . . . . . . . . . . . . . . .104

Figura 79 - Crescimento bacteriano e atividade específica da enzima nitrogenase de

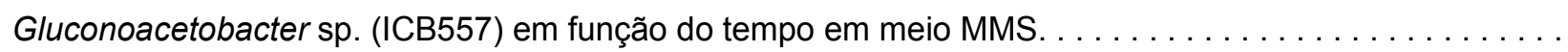
.105

Figura 80 - Concentração de AIA livre detectada em meio MMS em função do tempo em culturas de Gluconoacetobacter sp. ICB409. 106

Figura 81 - Crescimento bacteriano ao longo do tempo em culturas de bactérias isoladas de cana-deaçúcar adubada organicamente, convencionalmente ou não fertilizada. 107

Figura 82 - Atividade específica média da enzima nitrogenase (levando-se em conta todos os isolados) ao longo do tempo, em culturas de bactérias isoladas de cana-de-açúcar adubada organicamente,

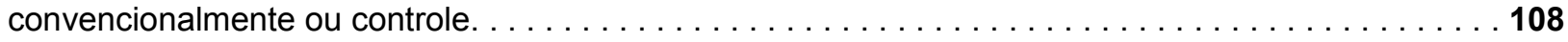

Figura 83 - Liberação média de aminoácidos (levando-se em conta todos os isolados) ao longo do tempo, em culturas de bactérias isoladas de cana-de-açúcar adubada organicamente,

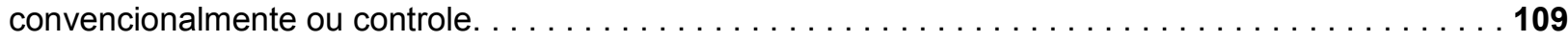

Figura 84 - Liberação média de poliaminas (levando-se em conta todos os isolados) ao longo do tempo, em culturas de bactérias isoladas de cana-de-açúcar adubada organicamente, convencionalmente ou controle.

Figura 85 - Liberação média de AIA (levando-se em conta todos os isolados) ao longo do tempo, em culturas de bactérias isoladas de cana-de-açúcar adubada organicamente, convencionalmente ou 
controle.

\section{LISTA DE TABELAS}

Tabela 1 - Linhagens bacterianas estudadas quanto à capacidade de liberar aminoácidos, poliaminas, AIA e etileno; tratamento aplicado à cana-de-açúcar de onde as bactérias foram isoladas; e data de coleta dos microrganismos . .

Tabela 2 - Meios de cultura para bactérias fixadoras de nitrogênio

Tabela 3 - Seqüência dos "primers" utilizados para amplificação dos genes 16S rRNA e housekeeping" . .

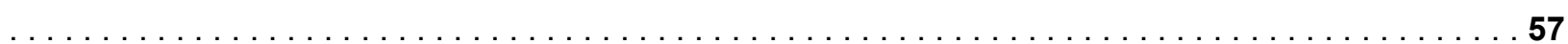

Tabela 4 - Identificação dos 12 isolados de cana-de-açúcar, submetida à fertilização orgânica, convencional ou sem adubação, obtida por sequenciamento do gene $16 \mathrm{~S}$ rRNA . . . . . . . 59

Tabela 5 - Concentrações de etileno detectadas em culturas de linhagens de Enterobacter sp. após 144

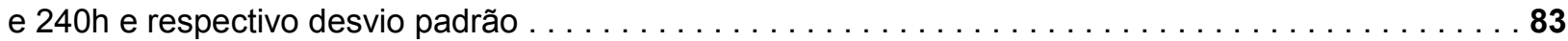

Tabela 6 - Concentrações de etileno detectadas em culturas de linhagens de Klebsiella sp. após 144 e

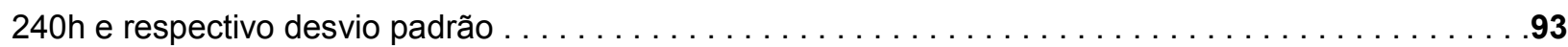

Tabela 7 - Porcentagem de bactérias isoladas de cana-de-açúcar submetida aos diferentes tratamentos, que apresentaram a nitrogenase ativa em cada um dos pontos da curva de crescimento

Tabela 8 - Porcentagem de bactérias capazes de liberar substâncias promotoras de crescimento vegetal em meio de cultura de acordo com o tratamento dado à cana-de-açúcar de onde foram isolados . . . 109

Tabela 9 - Concentrações médias de substâncias liberadas por bactérias isoladas de cana-de-açúcar submetida ao tratamento orgânico, convencional ou controle e respectivos erros padrões, levando em conta apenas o pico de liberação de cada substância $\ldots \ldots \ldots \ldots \ldots \ldots \ldots \ldots \ldots \ldots \ldots \ldots \ldots \ldots \ldots$

Tabela 10 - Linhagens bacterianas identificadas por sequenciamento do gene $16 S$ rRNA. Diferenças encontradas entre as identificações obtidas com fragmentos menores que $600 \mathrm{pb}$ e maiores que $1300 \mathrm{pb}$. 


\section{LISTA DE ABREVIATURAS E SIGLAS}

ACC - 1-aminociclopropano-1-carboxilato

AIA - Ácido indol-3-acético

Ala - Alanina

Asp - Aspartato

BEFN - Bactérias endofíticas fixadoras de nitrogênio

Glu - Glutamato

Gly - Glicina

Ile - Isoleucina

IAAld - Indol-3-acetaldeido

IAAm - Indolacetamida

IPA - Ácido indol-pirúvico

Leu - Leucina

Met - Metionina

Orn - Ornitina

OPA - Orto-ftalaldeido

PGP - Promotores de crescimento de plantas

Phe - Fenilalanina

SAM - S-Adenosil-metionina

Ser - Serina

SPCV - Substâncias promotoras de crescimento vegetal

Tam - Triptamina

Trp - Triptofano

Tyr - Tirosina

UFC - Unidades formadoras de colônia

Val - Valina 


\section{SUMÁRIO}

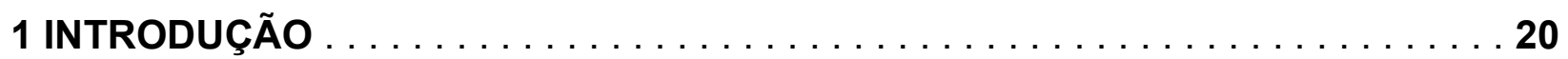

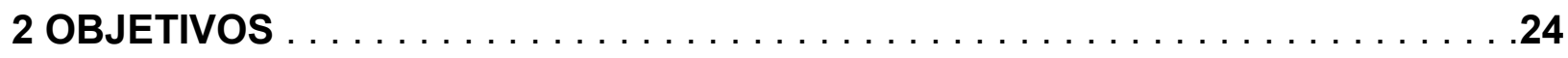

2.1 OBJETIVO GERAL. .................................

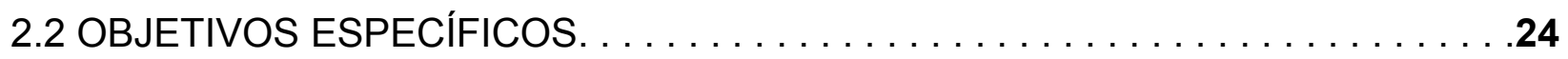

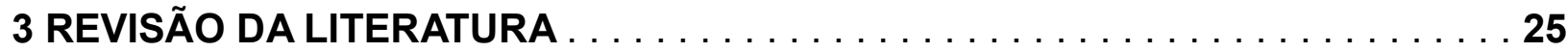

3.1 MICRORGANISMOS ENDOFITICOS. ....................... 25

3.2 BACTÉRIAS ENDOFÍTICAS FIXADORAS DE NITROGÊNIO (BEFN) $\ldots \ldots \ldots .27$

3.3 RHIZOBIUM . . . . . . . . . . . . . . . . . . . . . . . . . 30

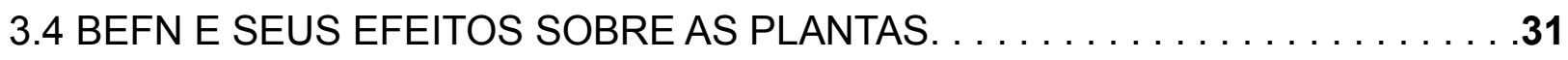

3.5 PRODUÇÃO DE AMINOÁCIDOS, POLIAMINAS E FITORMÔNIOS. ..........33

3.6 FERTILIZAÇÃO NITROGENADA E SEU EFEITO SOBRE BEFN . . . . . . . . . 39

3.7 AGRICULTURA ORGÂNICA ............................ 42

3.8 CANA DE AÇÚCAR E SUA IMPORTÂNCIA PARA O BRASIL $\ldots \ldots \ldots \ldots \ldots .43$

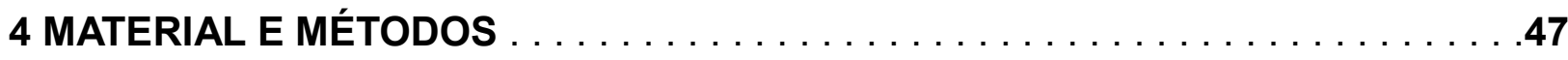

4.1 MATERIAL BIOLÓGICO ..............................47

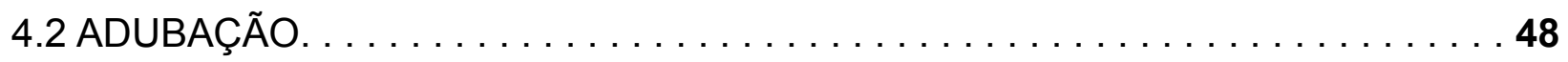

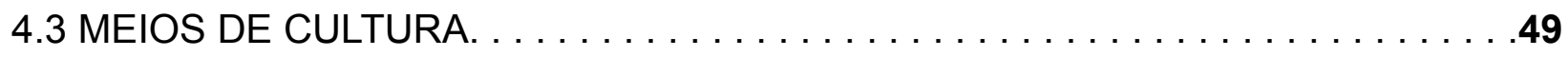

4.4 SOLUÇÕES. .................................... 51

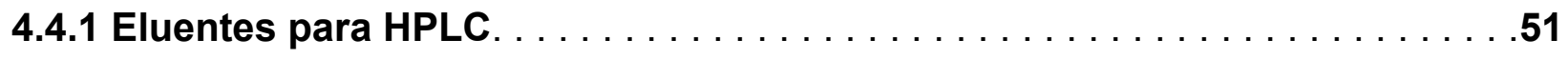

4.4.1.1 Análise de aminoácidos............................... 51

4.4.1.2 Análise de poliaminas. ................................51

4.4.1.3 Análise de AlA ................................. 51

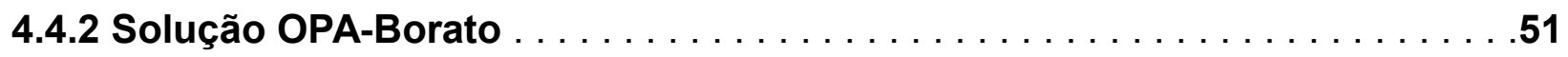

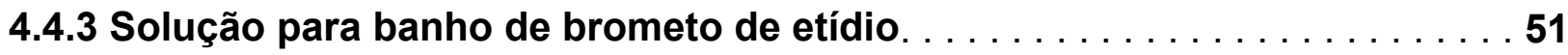

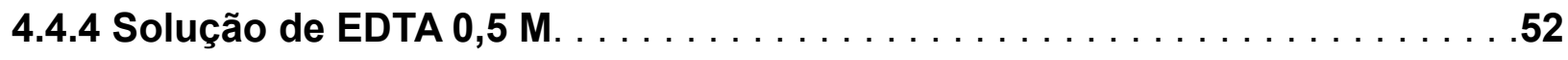

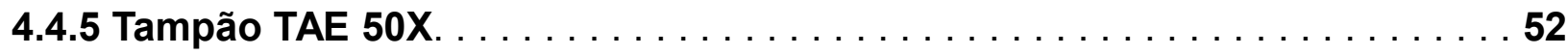

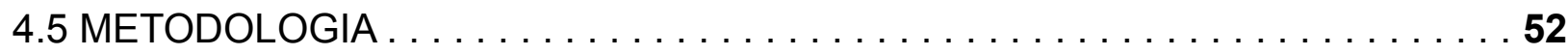

4.5.1 Testes fisiológicos $\ldots \ldots \ldots \ldots \ldots \ldots \ldots \ldots \ldots \ldots \ldots \ldots \ldots \ldots .52$ 
4.5.1.1 Crescimento das culturas para determinações de AIA, etileno, aminoácidos e

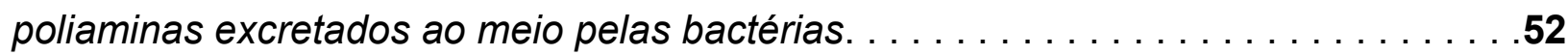

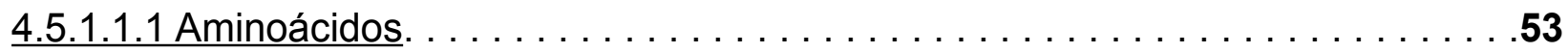

4.5.1.1.2 Poliaminas. . . . . . . . . . . . . . . . . . . . . . . . . . . 53

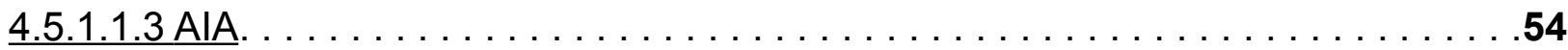

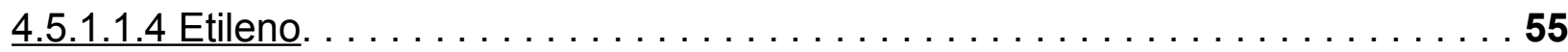

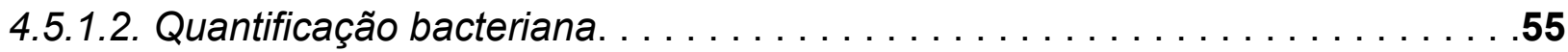

4.5.1.3 Medida da atividade específica da nitrogenase. Teste quantitativo de redução de acetileno.

56

4.5.2 Testes moleculares. . . . . . . . . . . . . . . . . . . . . 56

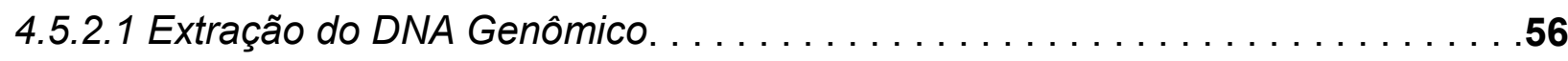

4.5.2.2 Amplificação dos fragmentos. . . . . . . . . . . . . . . . . . . . . . . . . 57

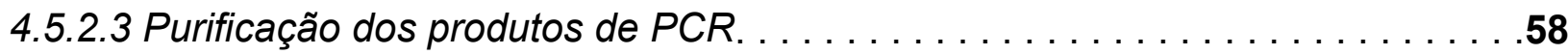

4.5.2.4 Reação de Seqüenciamento. . . . . . . . . . . . . . . . . . . . .58

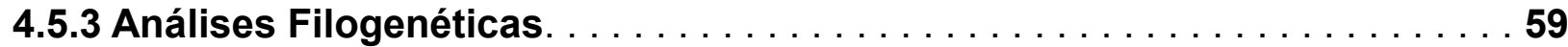

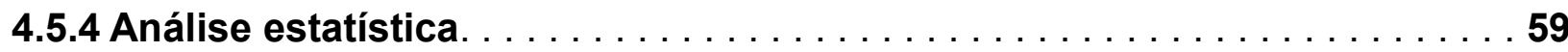

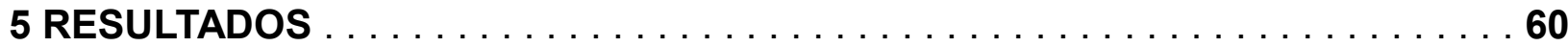

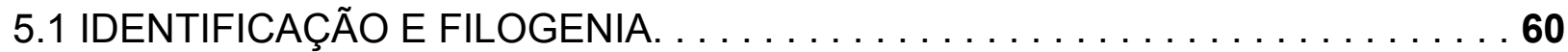

5.2 DOSAGEM DE SUBSTÂNCIAS LIBERADAS POR BEFN. . . . . . . . . . . 63

5.3 INFLUÊNCIA DA ADUBAÇÃO NAS CARACTERÍSTICAS FISIOLÓGICAS DOS ISOLADOS. . . . . . . . . . . . . . . . . . . . . . . . . . . . . . 107

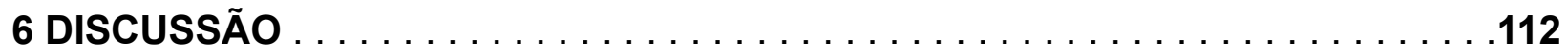

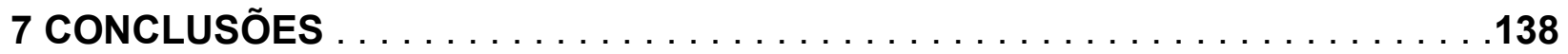

REFERÊNCIAS . . . . . . . . . . . . . . . . . . . . . . . . . . . . . 139

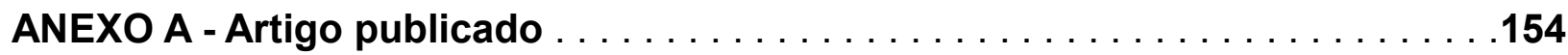

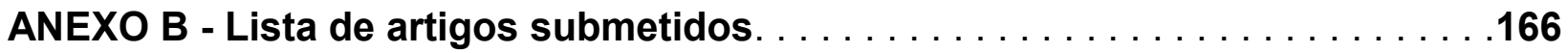




\section{INTRODUÇÃO}

Bactérias fixadoras de nitrogênio podem ser encontradas livres no solo, em associação simbiótica nas raízes de plantas ou endofíticamente, em todos os órgãos do vegetal (ROSENBLUETH; MARTINEZ-ROMERO, 2006).

A associação simbiótica, estabelecida entre o gênero Rhizobium e plantas leguminosas em nódulos localizados na raiz do vegetal, é extremamente estudada. Essa relação é baseada na troca de nitrogênio, fixado pelo microrganismo e transferido para a planta e carbono, fornecido à bactéria pelo vegetal. A fixação biológica de nitrogênio realizada por bactérias simbióticas contribui grandemente para uma agricultura sustentável uma vez que provê os agrossistemas com consideráveis quantidades de N (MARINO et al., 2006).

Microrganismos endofíticos colonizam ativamente tecidos vegetais, estabelecendo relações variáveis com o hospedeiro (SCHULZ; BOYLE, 2006). Bactérias e fungos são os endófitos mais comuns. Cada indivíduo pertencente a uma das cerca de 30 mil espécies de plantas existentes, é hospedeiro de um ou vários organismos endófíticos (STROBEL; DAISY, 2003). Geralmente, as densidades populacionais de bactérias endofíticas são menores que as de bactérias patogênicas, indicando que são reconhecidas diferentemente pelo vegetal e que se estabelecem de forma mais controlada. Evolutivamente, os endófitos parecem ser intermediários entre saprófitas e fitopatógenos, uma vez que obtém abrigo e nutrientes do hospedeiro sem Ihe causar danos (HALLMANN et al., 1997). As bactérias endofíticas colonizam 
espaços intercelulares e vasos xilemáticos, podendo daí promover o crescimento da planta direta ou indiretamente (WEYENS et al., 2009) de diferentes formas. Dentre elas, estão o possível estímulo pela transferência de nitrogênio fixado (HAN et al., 2005), solubilização de nutrientes (RODRIGUEZ; FRAGA, 1999; VERMA et al., 2001), liberação de hormônios de crescimento e vitaminas (PIRTTILA et al., 2004) produção de enzimas regulatórias (CORREA; BARRIOS; GALDONA, 2004) e antagonismo a organismos patogênicos (RENWICK; CAMPBELL; COE, 1991; PAL et al., 2001; KARTHIKEYAN et al., 2005; COMPANT et al., 2005).

Diferentes gêneros bacterianos, dentre eles Pseudomonas, Xanthomonas, Azotobacter, Klebsiella, Azospirillum, Acinetobacter, Bacillus, Burkholderia, Enterobacter, Erwinia, Rhizobium, Serratia e Herbaspirillum, são capazes de fixar $\mathrm{N}_{2}$ atmosférico e de sintetizar substâncias com potencial uso na promoção de crescimento vegetal (KLOEPPER et al., 1986; FRANKENBERGER; ARSHAD, 1995; ARSHAD; FRANKENBERGER, 1998; REINHOLD-HUREK; HUREK， 1998; GUTIÉRREZMAÑERO et al., 2001; TILAK et al., 2005; VIKRAM et al., 2007).

Ainda não está demonstrado como ocorre a transferência de nitrogênio fixado ao hospedeiro pelas bactérias endofíticas. No entanto, Urquiaga; Cruz e Boddey (1992) mostraram que diferentes cultivares de cana-de-açúcar obtiveram grandes quantidades de nitrogênio fixado por bactérias endofíticas. Bactérias diazotróficas podem contribuir para o crescimento vegetal independente da fixação de $\mathrm{N}_{2}$. Estudos com mutantes nifevidenciaram maior desenvolvimento de plantas inoculadas pela produção de PGPs (HUREK et al., 1994; HALLMANN et al., 1997). 
A liberação de substâncias promotoras de crescimento vegetal (SPCV) nitrogenadas, sintetizadas a partir do $\mathrm{N}_{2}$ é vantajosa, pois implica que a planta produza menos quantidade dessas substâncias e a fixação de $\mathrm{N}_{2}$ impede a competição, por outras fontes de $\mathrm{N}$-combinado. Herbaspirillum seropedicae e A. diazotrophicus sintetizam ácido indol-3-acético (AIA) e as giberelinas $A_{1}$ e $A_{3}$ em meios quimicamente definidos (BASTIÁN et al., 1998) e o gênero Azospirillum produz substâncias do tipo citocininas (STRZELCZYK; KAMPERT; LI, 1994). Azospirillum sp, isolado do interior de raiz de mandioca liberou, no meio de cultura, hormônios como AIA e etileno, reguladores de crescimento como poliaminas e outras substâncias nitrogenadas, como aminoácidos (THULER et al., 2003a).

Para a classificação taxonômica de microrganismos em geral tem sido amplamente usada a identificação molecular incluindo diazotróficos endofíticos e simbiontes (RIVAS et al., 2009; DELÉTOILE et al., 2009). Para esse tipo de estudo o gene mais utilizado é o que codifica o 16sRNA ribossômico, que se manteve conservado durante a evolução sendo, por isso, informativo a respeito da posição taxonômica das bactérias (ZEIGLER, 2003). Entretanto, justamente por ser bem conservado, seu sequenciamento permite obter informações apenas no nível de gênero. Há necessidade de se estudar outros genes para se estabelecer corretamente a filogenia bacteriana indicando a distância evolutiva entre os isolados (ZEIGLER, 2003). 
O cultivo secular da cana-de-açúcar (Saccharum sp.) com a utilização de poucas quantidades de fertilizantes nitrogenados, sem que houvesse o esgotamento das reservas de $\mathrm{N}$ do solo, levou a sugestão de que bactérias diazotróficas associadas a planta poderiam ser a fonte de $\mathrm{N}$ para essas culturas (BODDEY et al., 2004). Estudos de interações entre planta e bactérias diazotróficas mostraram que a cana-de-açúcar pode obter quantidades substanciais de nitrogênio fixado biologicamente quando inoculada com estes microrganismos (MUTHUKUMARASAMY; REVATHI, 1999).

A preocupação com a fertilização nitrogenada, que é danosa ao meio ambiente, fez com que se implantassem alternativas para se adubar as culturas vegetais ao redor do mundo. Consistindo na aplicação de compostos orgânicos residuais de plantas já processadas A agricultura orgânica resulta em menor lixiviação de nutrientes e maior utilização de carbono para o crescimento, menos erosões, maior biodiversidade e menores níveis de pesticidas nos sistemas hídricos (REGANOLD et al., 1987; DRINKWATER et al., 1995; KREUGER; PETERSON; LUNGREN, 1999; MADER et al., 2002; KRAMER et at., 2006). Considerando que o tipo de adubação interfere inclusive em níveis moleculares por alteração da expressão de determinados genes bacterianos (PRAKAMHANG et al., 2009), pode-se supor que a produção de substâncias ativas em plantas seja alterada de acordo com o tipo de fertilização ou sua ausência.

O presente trabalho teve como intuito, mostrar se a adubação orgânica interfere positivamente em características relacionadas à promoção de crescimento vegetal de bactérias diazotróficas endiofíticas isoladas de cana-de-açúcar quando comparada à 
adubação convencional.

\section{OBJETIVOS}

\subsection{OBJETIVO GERAL}

- Comparar a influência do tipo de adubação aplicado em canavial sobre características fisiológicas relacionadas à promoção de crescimento vegetal de bactérias endofíticas isoladas de cana-de-açúcar.

\subsection{OBJETIVOS ESPECÍFICOS}

- Identificar as bactérias diazotróficas endofíticas isoladas de cana-de-açúcar submetida às adubações orgânica e convencional ou sem adubação. A identificação de linhagens de Rhizobium é particularmente importante pela ausência de literatura indicando o isolamento desse gênero do interior de canade-açúcar.

- Determinar quantitativamente a capacidade dessas bactérias liberarem em meio de cultura:

1- aminoácidos

2- poliaminas

3- Ácido indol-3-acético

4- Etileno

- Comparar ao longo do tempo a liberação desses compostos em isolados dos três diferentes tratamentos.

- Comparar as concentrações máximas de substâncias promotoras de crescimento vegetal excretadas pelas bactérias diazotróficas, independentemente do tempo. 


\section{REVISÃO BIBLIOGRÁFICA}

\subsection{MICRORGANISMOS ENDOFÍTICOS}

Microrganismos endofíticos residem de forma latente ou colonizam ativamente tecidos de plantas, estabelecendo relações variáveis com o hospedeiro, desde simbiose até traços de patogenia. Bactérias e fungos são os endófitos mais comuns, sendo considerados ubíquos na maioria das plantas (STROBEL; DAISY, 2003). No entanto, não se tem total conhecimento sobre o papel dos endófitos na natureza e nem sobre suas reais relações com as espécies hospedeiras.

Bactérias endofíticas se originam de comunidades bacterianas do solo. $\mathrm{Na}$ rizosfera, há uma seleção de bactérias pelos exudatos vegetais. As bactérias com capacidade de se tornarem endofíticas se aderem ao rizoplano e formam microcolônias. A penetração, a partir dessas microcolônias, nas raízes das plantas pode ocorrer via feridas, por áreas de emergência de raízes laterais, zonas de alongamento e radículas em germinação (HUANG, 1986; SPRENT; DE FARIA, 1988; ROSENBLUETH; MARTINEZ-ROMERO, 2006). Pode haver também uma penetração ativa nos tecidos vegetais pela secreção de enzimas hidrolíticas (JAMES et al., 2002; COMPANT et al., 2008) cuja produção ocorre apenas quando se observa a colonização da epiderme da raiz, sugerindo que tenham por função apenas a penetração da planta (HALLMANN et al., 1997; VERMA; LAHDA; TRIPATHI, 2001). A colonização endofítica pode ser local ou sistêmica. 
Bactérias endofíticas são necessariamente reconhecidas pela planta para se estabelecerem nos tecidos internos e se espalharem por todo o vegetal. Aparentemente, a produção de enzimas como a endoglucanase e endopoligalacturonase está envolvida nesse processo (REINHOLD-HUREK et al., 2006; COMPANT et al., 2008). Evolutivamente, os endófitos parecem ser intermediários entre saprófitas e fitopatógenos uma vez que obtém, por um lado, abrigo e nutrientes e por outro lado, não causam danos o hospedeiro (HALLMANN et al., 1997).

Correntemente microrganismos endofíticos são vistos como fontes de produtos bioativos naturais porque eles são muitos e ocupam milhões de nichos ecológicos únicos (plantas superiores), crescendo em vários ambientes peculiares. Estes motivos aumentam a possibilidade de se encontrar microrganismos endofíticos novos e interessantes (STROBEL; DAISY, 2003). Já foram demonstradas as sínteses de muitas substâncias, geralmente metabólitos secundários, com potencial uso na medicina moderna, na agricultura e indústria. Por este motivo, há estudos voltados ou para descoberta de novas substâncias ou para pesquisar, dentre as já conhecidas, condições capazes de incrementar suas produções (STROBEL; DAISY, 2003). Produtos naturais têm atualmente um imenso impacto na humanidade. A necessidade de suficiente alimento, de suprimento de medicamentos e a procura de novos antimicrobianos estão diretamente relacionados a problemas que necessitam de rápidas soluções.

Dentre os produtos naturais produzidos por bactérias endofíticas pode-se 
destacar os anticancerígenos e antibióticos de vários tipos: antifúngicos, antibacterianos, antivirais e antiprotozoários, por bactérias (MILLER et al., 1998; STROBEL et al., 1999; GUO et al., 2000; RYAN et al., 2008). Substâncias com atividade antioxidante com estrutura similar a flavonóides também foram detectadas (STROBEL et al., 2002).

Outra propriedade importante de endofíticos é a produção de fitoquímicos. Baseado em bioensaios, usando tubérculos de batata saudáveis, Sturz (1995) descreveu substâncias promotoras de crescimento de plantas, de retardadoras de crescimento e neutras produzidas por Pseudomonas, Bacillus, Xanthomonas, Agrobacterium, Actinomyces e Acinetobacter. A razão pela qual os microrganismos produziriam certos fitoquímicos originalmente característicos do hospedeiro é que com a evolução, tenham ocorrido trocas de genes entre endofíticos e hospedeiro pela ocorrência de recombinações genéticas (TAN; ZOU, 2001; MORAN et al., 2007).

\subsection{BACTÉRIAS ENDOFÍTICAS FIXADORAS DE NITROGÊNIO (BEFN)}

A literatura cita várias espécies de bactérias endofíticas isoladas de diferentes tipos de plantas. Como exemplos pode-se citar Agrobacterium, Arthrobacter, Bacillus, Burkholderia, Clavibacter, Chryseobacterium, Enterobacter, Erwinia, Micrococcus, Pseudomonas, Rhodococcus, Xanthomonas, Citrobacter, Klebsiella, Pantoea, Serratia, Salmonella, (HALLMANN et al., 1997; ENGELHARDT; HUREK; REINHOLD-HUREK, 2000; ELBELTAGY et al., 2001; SANDHIYA et al., 2005; FENG; SHEN; SONG, 2006; WANG et al., 2006). Dentre os gêneros encontrados, foram relatados diversos com 
capacidade de fixar nitrogênio atmosférico (REINHOLD-HUREK; HUREK, 1998; ROSENBLUETH; MARTINEZ-ROMERO, 2006).

O nitrogênio é um elemento essencial aos organismos vivos, por participar de macromoléculas fundamentais como proteínas, ácidos nucléicos etc. A capacidade fixar $\mathrm{N}_{2}$, representa uma vantagem competitiva aos microrganismos diazotróficos, que sobrevivem em ambientes carentes de $\mathrm{N}$-combinado, utilizando-se do elemento $\mathrm{N}_{2}$ presente em grande quantidade na atmosfera. A fixação de nitrogênio ocorre em poucas espécies de bactérias. A enzima nitrogenase, característica desses organismos diazotróficos, catalisa a quebra da tripla ligação da molécula de $\mathrm{N}_{2}$, produzindo $\mathrm{NH}_{3}$, assimilável por grande parte dos seres vivos (KIM; REES, 1994). A nitrogenase é um complexo formado por duas proteínas, a dinitrogenase (proteína 1) e dinitrogenase redutase (proteína 2) que atuam em seqüência (Figura 1).

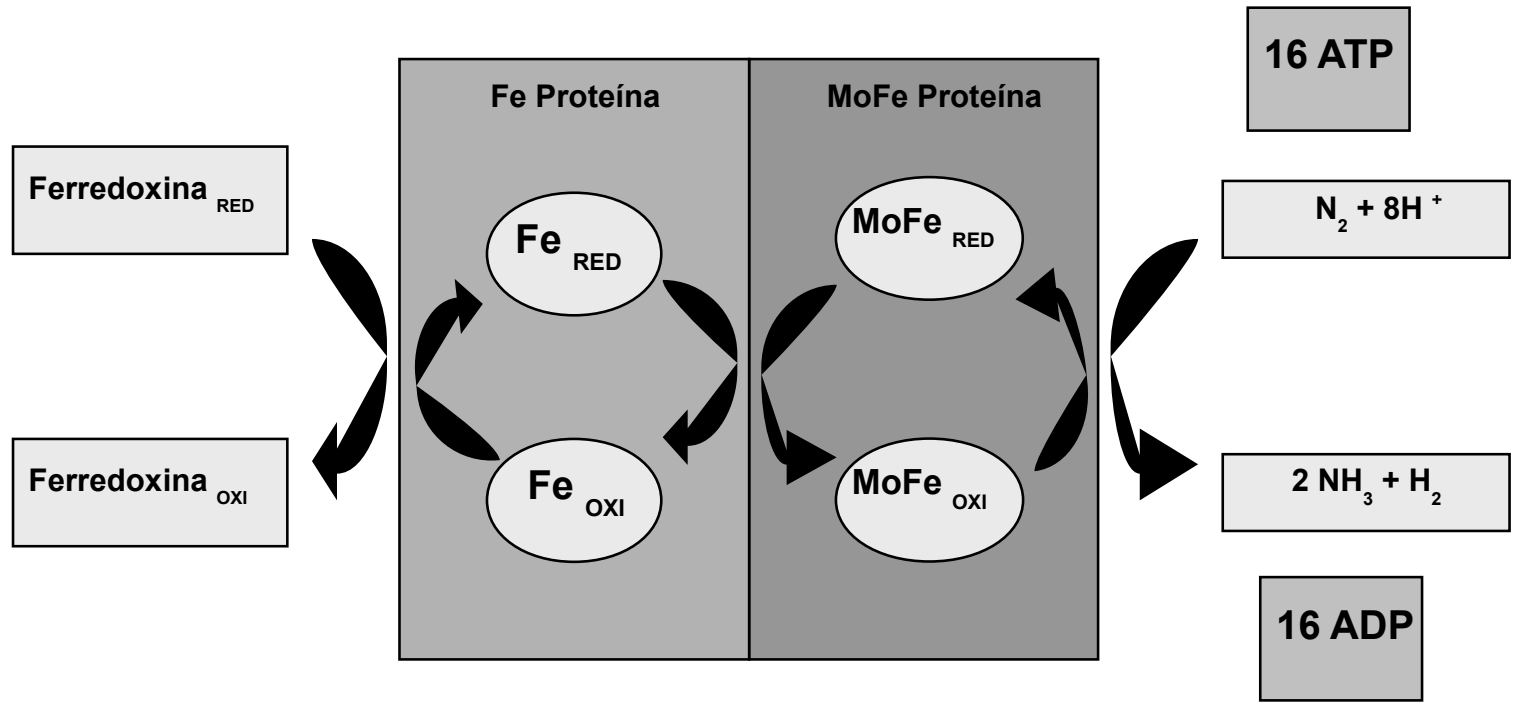

Figura 1 - Esquema de ativação da nitrogenase. A transferência sequencial de elétrons se inicia com a ferredoxina. O elétron é trensferido para a Fe-proteína e em em seguida para a MoFeproteína. No "cluster" FeMo, ocorre ocorre a ligação do substrato é quebrado ao custo de 16 ATPs. $\mathrm{O} \mathrm{N}$ recebe os elétrons em sequência formando o $\mathrm{NH}_{3}$.

O processo de redução do $\mathrm{N}_{2}$ inicia-se pela transferência de elétrons da ferredoxina ou 
flavodoxina para a dinitrogenase que, reduzida, doa esses elétrons para a dinitrogenase redutase onde está ligado o substrato; este recebe os elétrons formando o produto $\mathrm{NH}_{3}$ (REES; HOWARD, 2000). Este produto pode ser incorporado às estruturas bacterianas levando ao crescimento do microrganismo, pode ser liberado ao meio na forma de produtos nitrogenados ou transformado em reserva proteica (STEENHOUDT; VANDERLEYDEN, 2000; THULER et al., 2003a,b; ELBAHLOUL et al., 2005). A nitrogenase, como outras enzimas, cessa sua atividade quando em presença de uma quantidade grande de seu produto. Assim, a presença de amônio no meio inibe a atividade e posteriormente a síntese da enzima (STEENHOUDT; VANDERLEYDEN, 2000) Um dado importante é que a nitrogenase é irreversivelmente inibida em presença de $\mathrm{O}_{2}$ atmosférico (BURRIS, 1991). Algumas bactérias desenvolveram mecanismos de defesa para a enzima (aeróbias estritas) e vivem em aerobiose sem afetar a atividade da enzima. Outras, como as endofíticas, necessitam de um ambiente com baixo teor de $\mathrm{O}_{2}$ (microaerofilia) para fixar $\mathrm{N}_{2}$ (BECANA; RODRIGUEZ-BARRUECO, 1989).

Além de $\mathrm{N}_{2}$, a nitrogenase possui a capacidade de reduzir outros substratos que apresentam duas ou três ligações, como azida $\left(\mathrm{N}_{3}{ }^{-}\right)$, óxido nitroso $\left(\mathrm{N}_{2} \mathrm{O}\right)$ e acetileno $\left(\mathrm{C}_{2} \mathrm{H}_{2}\right)$ (CHRISTIANSEN; SEEFELDT; DEAN, 2000). O acetileno é particularmente importante, pois seu uso como substrato levou ao desenvolvimento de uma técnica: ensaio de redução de acetileno (ARA) que permite a determinação da atividade da nitrogenase em laboratório, com grande facilidade e em pouco tempo. O etileno, produto desta reação, pode ser detectado com grande sensibilidade por cromatografia gasosa (ANDERSON et al., 2004). 
Ainda estão em esclarecimento as vantagens que a fixação de nitrogênio pode trazer para o hospedeiro, quando colonizado por bactérias endofíticas. $O$ processo desenvolvido pelas bactérias simbióticas que compõem o sistema rizóbio/leguminosa, bastante estudado e conhecido, trouxe esclarecimentos dos grandes benefícios que os organismos envolvidos obtém dessa associação.

\subsection{RHIZOBIUM}

O gênero Rhizobium é o mais estudado em associação com plantas. Sua interação envolve mecanismos específicos de reconhecimento, penetração, invasão e simbiose com grande benefício de ambos os parceiros (FRANCHE; LINDSTROM; ELMERICH, 2009).

Rhizobium reconhece determinados flavonóides específicos exudados pela planta com a qual se associa. Por meio de um polissacarídeo de membrana externa, a bactéria se liga a uma proteína encontrada nos pelos radiculares do vegetal. Os genes nod são ativados na bactéria e produzem os fatores Nod que atuam desde a formação de um biofilme bacteriano, na superfície das raízes, até o desenvolvimento do nódulo e fixação de nitrogênio (FUJISHIGE et al., 2008).

Rhizobium obtém abrigo e fonte de carbono da planta, fornecendo, em troca, nitrogênio combinado na forma de amônia (FRANCHE; LINDSTROM; ELMERICH, 2009). Esta interação permite que o produto da fixação de nitrogênio seja incorporado 
pelo vegetal, com aumento do teor protéico do hospedeiro. Na agricultura essa associação se mostrou importante, pois foi possível substituir grande parte da fertilização nitrogenada e, atualmente, esta simbiose é largamente aplicada, com conseqüências extremamente importantes para o ambiente. $O$ fato desta modalidade de relação ser exclusiva à família leguminosa torna imperioso o estudo de outras interações mais abrangentes, envolvendo, por exemplo, bactérias ubíquas como as endofíticas fixadoras de $\mathrm{N}_{2}$ que liberem substâncias nitrogenadas a partir do $\mathrm{N}$ fixado.

Além da associação com leguminosas, a competência de diferentes linhagens de Rhizobium em promover o crescimento vegetal tem sido mostrada através de sua inoculação em diversas plantas de outras famílias (BISWAS; LADHA; DAZZO, 2000; MEHBOOB; NAVEED; ZAHIR, 2009).

\subsection{BEFN E SEUS EFEITOS SOBRE AS PLANTAS}

A inoculação de plantas com BEFN evidenciou seus efeitos positivos em trabalhos precursores, porém ainda não se demonstrou que haja transferência de nitrogênio fixado ao hospedeiro em todas as interações relatadas. Okon et al. (1983) mostraram que apenas pequena porção do nitrogênio fixado pela bactéria foi incorporada em Setaria italica inoculada com Azospirillum brasilense. Ruschel e Vose (1984) detectaram a fixação de nitrogênio dentro das raízes de cana-de-açúcar, embora em baixos níveis. Boddey e Dobereiner (1988) não evidenciaram ocorrência de fixação biológica de nitrogênio em resposta à inoculação com Azospirillum spp em gramíneas e cereais. Urquiaga, Cruz e Boddey (1992), no entanto, mostraram que 
diferentes cultivares de cana-de-açúcar incorporaram grandes e significantes quantidades de nitrogênio fixado por bactérias endofíticas. Sabe-se hoje que alguns cultivares de cana-de-açúcar podem obter até $150 \mathrm{~kg} \mathrm{~N} \cdot \mathrm{ha}^{-1} \cdot$ ano $^{-1}$ provenientes da fixação biológica de nitrogênio (BODDEY et al., 2001).

Dentre os efeitos benéficos da presença das BEFN estão a promoção do crescimento de diversas culturas vegetais pela produção de vários fitoquímicos, detectados em diferentes culturas bacterianas. Herbaspirillum seropedicae e A. diazotrophicus sintetizam ácido indol-3-acético (IAA) e as giberelinas $A_{1}$ e $A_{3}$ em meios quimicamente definidos (BASTIÁN et al., 1998) e Azospirillum e Pseudomonas produzem substâncias do tipo citocininas (STRZELCZYK; KAMPERT LI, 1994; DE SALAMONE; HYNES; NELSON, 2001). Azospirillum sp. isolado endofítico de mandioca, também é capaz de liberar, no meio de cultura, hormônios como IAA e etileno, reguladores de crescimento como poliaminas e substâncias nitrogenadas, como aminoácidos, que podem ser diretamente incorporados a macromoléculas (THULER et al., 2003a).

Os efeitos "in vivo" exercidos pelos microrganismos sobre os hospedeiros foram observados tanto por inoculação das BENF em sementes e plântulas quanto por contato externo, principalmente em raízes. Estes órgãos demonstraram fortes evidências desses efeitos: aumento do comprimento, biomassa e do número de raízes laterais e raízes emergentes apresentaram-se densamente cobertas de pelos (TIEN; GASKINS; HUBBELL, 1979; BARBIERI et al., 1986; MAYAK; TIROSH; GLICK, 1999; 
MEHNAZ et al., 2010). Além disso, foram observados estímulos no desenvolvimento de sementes (GLICK et al., 1997). Essas alterações podem ser atribuídas à liberação de fitormônios pelas bactérias.

\subsection{PRODUÇÃO DE AMINOÁCIDOS, POLIAMINAS E FITORMÔNIOS}

Os aminoácidos são compostos essenciais para todos os organismos por constituírem as proteínas. Apenas 20 aminoácidos ocorrem naturalmente em proteínas, entretanto, uma única molécula de proteína pode conter entre 50 e centenas de aminoácidos, organizados das mais diferentes formas. Todos os aminoácidos são formados por um radical ligado a um carbono que se liga ainda a um grupo amina $\left(-\mathrm{NH}_{2}\right)$ um grupo carboxila $(-\mathrm{COOH})$ e um hidrogênio $(-\mathrm{H})$. Apesar de muitos microrganismos serem capazes de sintetizar todos os aminoácidos, há poucos dados na literatura indicando sua capacidade de liberá-los ao meio.

Em relação a microrganismos fixadores de nitrogênio detectou-se que Beijerinckia derxii, bactéria de vida livre, liberou ao meio 14 tipos diferentes de aminoácidos (THULER et al., 2003b). Pati et al. (1994) verificaram que Azotobacter chroococcum, Beijerinckia indica e Corynebacterium sp. liberavam diferentes aminoácidos no meio, assim como Azospirillum sp. (THULER et al., 2003a). Liba et al. (2006) descreveram diferentes gêneros bacterianos diazotróficos, isolados de liquens, como Pseudomonas, Pantoea e Acinetobacter capazes de liberar aminoácidos.

A liberação de aminoácidos na rizosfera torna os microrganismos que os produzem, importantes cooperadores do ambiente, pois vários outros seres vivos 
podem se favorecer desta liberação. Quando são endofíticos, se forem capazes de sintetizar aminoácidos a partir de nitrogênio fixado e liberá-los dentro da planta, tornarse-ão de grande importância para o vegetal, com efeitos que se aproximariam aos dos rizóbios para as leguminosas.

O ácido indol-3-acético (AIA) é um fitormônio da classe das auxinas envolvido em vários processos de crescimento, como alongamento, divisão e diferenciação celular. No alongamento celular, o AIA atua aumentando a extensibilidade da parede (TAIZ; ZIEGER, 2002). Den Boer e Murray (2000) afirmam que é necessário o estimulo de auxinas para desencadear a mitose nas células de raízes das plantas. As maiores concentrações de AIA na planta ocorrem em regiões meristemáticas e órgãos em crescimento, como sementes, e pontas de raízes. Folhas jovens de crescimento rápido, inflorescências em desenvolvimento e embriões após a fertilização também são sítios de intensa síntese desse hormônio (TAIZ; ZIEGER, 2002).

A produção de AIA foi detectada "in vitro" por diversas bactérias fixadoras de nitrogênio endofíticas obrigatórias ou facultativas, como Herbaspirillum seropedicae e Gluconacetobacter diazotrophicus, (BASTIÁN et al., 1998), Azospirillum sp. (THULER et al., 2003a), Azotobacter, Pseudomonas, Agrobacterium, Rhizobium, Bradyrhizobium, e Mezorhizobium, Bacillus e Burkholderia (COSTACURTA; VANDERLEYDEN, 1995; MENDES et al., 2007; AHMAD; AHMAD; KHAN, 2008). Tuomi, Laakso e Rosenqvist (1995) isolaram 16 linhagens de bactérias de grãos de cevada das quais $88 \%$ produziam AIA. 
O crescimento das plantas tratadas com bactérias que secretam AIA é afetado pela quantidade do hormônio produzido e a resposta pode variar dependendo da planta (GLICK, 1995). Zimmer e Bothe (1988) demonstraram que a inoculação de Azospirillum ao meio, promovia após 10 dias, o crescimento de raízes de trigo e maior quantidade de pelos e raízes laterais. A inoculação de AIA exógeno aumentou consideravelmente o peso seco dos segmentos das raízes da planta. Ao contrário, plântulas inoculadas com Pseudomonas capazes de liberar quatro vezes mais AIA que a linhagem selvagem, tiveram seu crescimento inibido.

Triptofano (Trp) é a substância precursora do AIA e os microrganismos podem utilizar-se de várias vias para fazer essa transformação. As vias mais caracterizadas são a do ácido indol-3-pirúvico (IPA) (1), a da triptamina (Tam) (2) e a da indolacetamida (IAAm) (3) segundo Patten e Glick (1996), Koga et al. (1991) e Spaepen, Vanderleyden e Remans (2007):

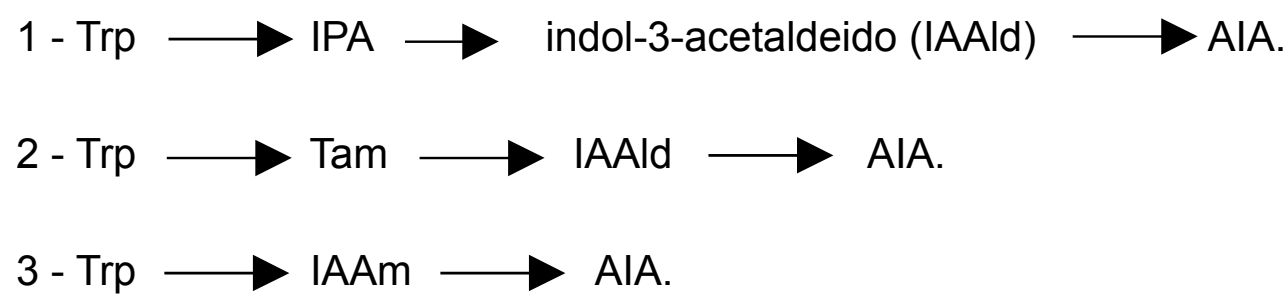

Em plantas há inúmeras vias de produção de AIA Spaepen, Vanderleyden e Remans (2007). Várias delas não usam o Trp como precursor. Independentemente da via de síntese, o AIA pode ser transportado para outras partes da planta, conjugado, 
degradado ou armazenado (BUCHANAN; GRUISSEM; JONES, 2000) como demonstrado na figura 2.

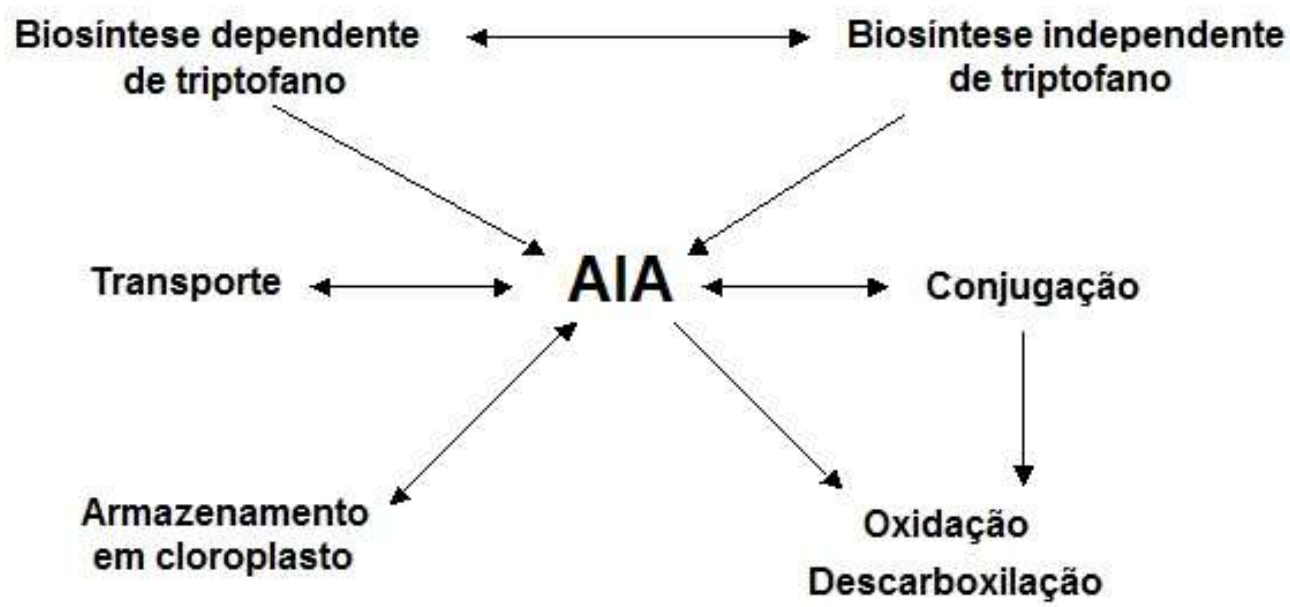

Figura 2 - Sinteses de AIA, dependente e independente de triptofano e possíveis destinos do fitormônio no vegetal: transporte, conjugação, oxidação e armazenamento em cloroplastos.

O etileno é um fitormônio presente em todos os órgãos das plantas, porém sua taxa de produção é variável. Parece ser sintetizado primariamente em resposta ao estresse ambiental e em grande quantidade para germinação de sementes, indução de senescência dos órgãos e amadurecimento de frutos. Hoje se sabe que o etileno afeta cada aspecto do crescimento da planta como a diferenciação celular entre outros (GRICHKO; GLICK, 2001; TAIZ; ZIEGER, 2002). O etileno e seu precursor, acid 1aminocylopropano-1-carboxilico (ACC) atuam da mesma forma na planta (ZHANG et al., 2008). Quando as plantas são submetidas a condições de estresse respondem com ums superprodução de etileno que pode retardar o crescimento vegetal, causar danos teciduais ou facilitar a infecção por microrganismos patogênicos (GLICK et al., 2007).

Em alguns solos, cerca de $30 \%$ dos microrganismos produzem etileno a uma 


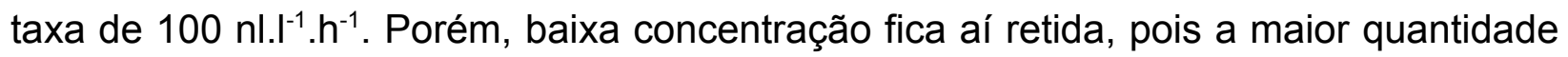
escapa para o ar (GRICHKO; GLICK, 2001).

Berner, Schaad e Völksch (1999) mostraram que o etileno produzido por Pseudomonas syringae pode ser utilizado para germinar sementes de Striga spp., planta parasita que necessita de etileno exógeno para iniciar seu desenvolvimento. $\mathrm{O}$ uso das bactérias se mostrou mais eficiente que qualquer outro método para desencadear seu crescimento.

O etileno é produzido a partir da metionina (Met) reciclada pela célula no ciclo de Yang (Figura 3).

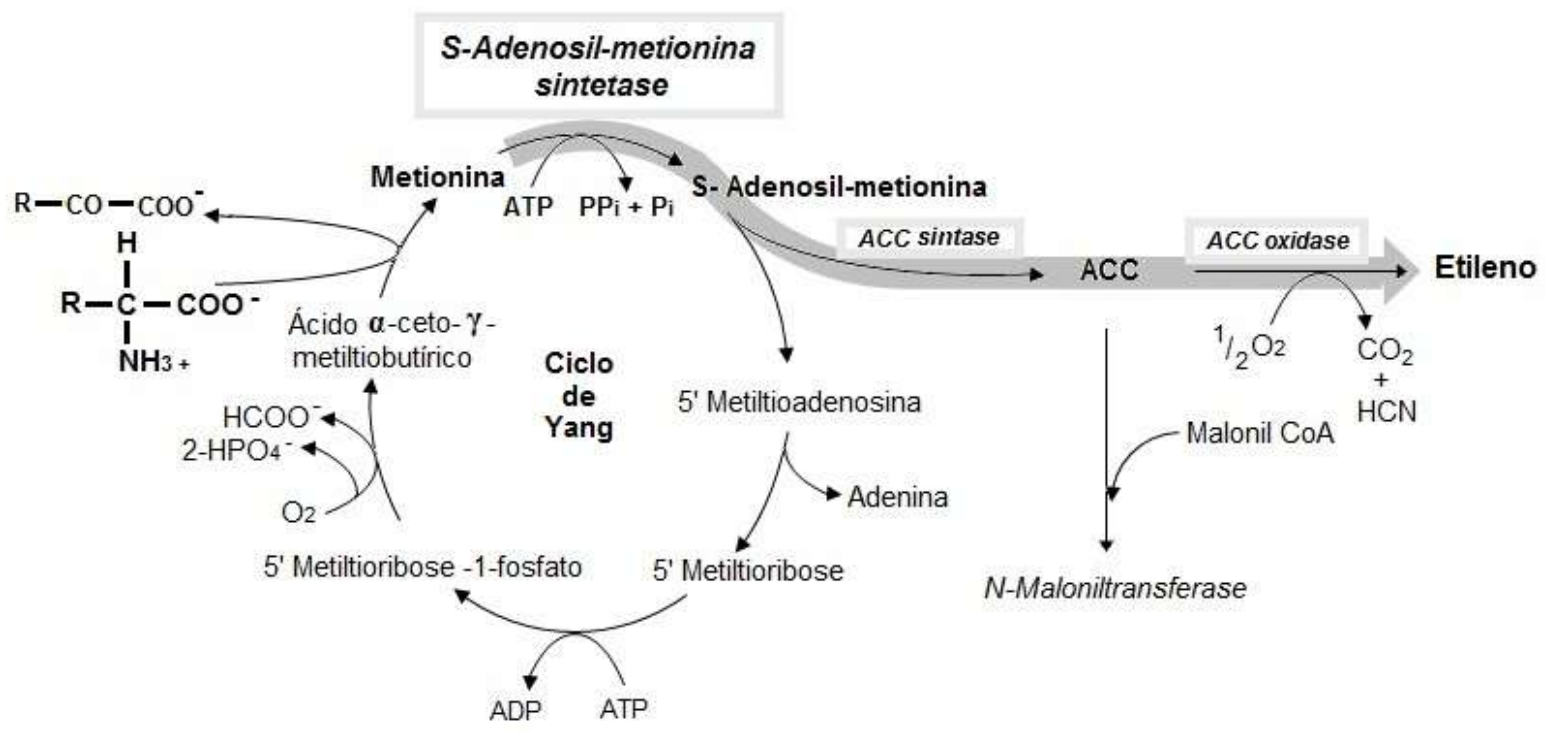

Figura 3 - Ciclo de Yang. Reciclagem da metionina e via de síntese de etileno (realçada em cinza) Fonte: Adaptado de Kays e Paull (2004). 
Outras substâncias que podem atuar em associações entre bactérias e plantas são as poliaminas. Estas substâncias são compostos alifáticos polivalentes que contêm dois ou mais grupos amina e são derivadas biossinteticamente da Arginina (Arg) e da Ornitina (Orn). A síntese de espermina e espermidina e do etileno estão relacionadas pelo intermediário comum S-adenosil-metionina (SAM), podendo apresentar aí um ponto de regulação (Figura 4).

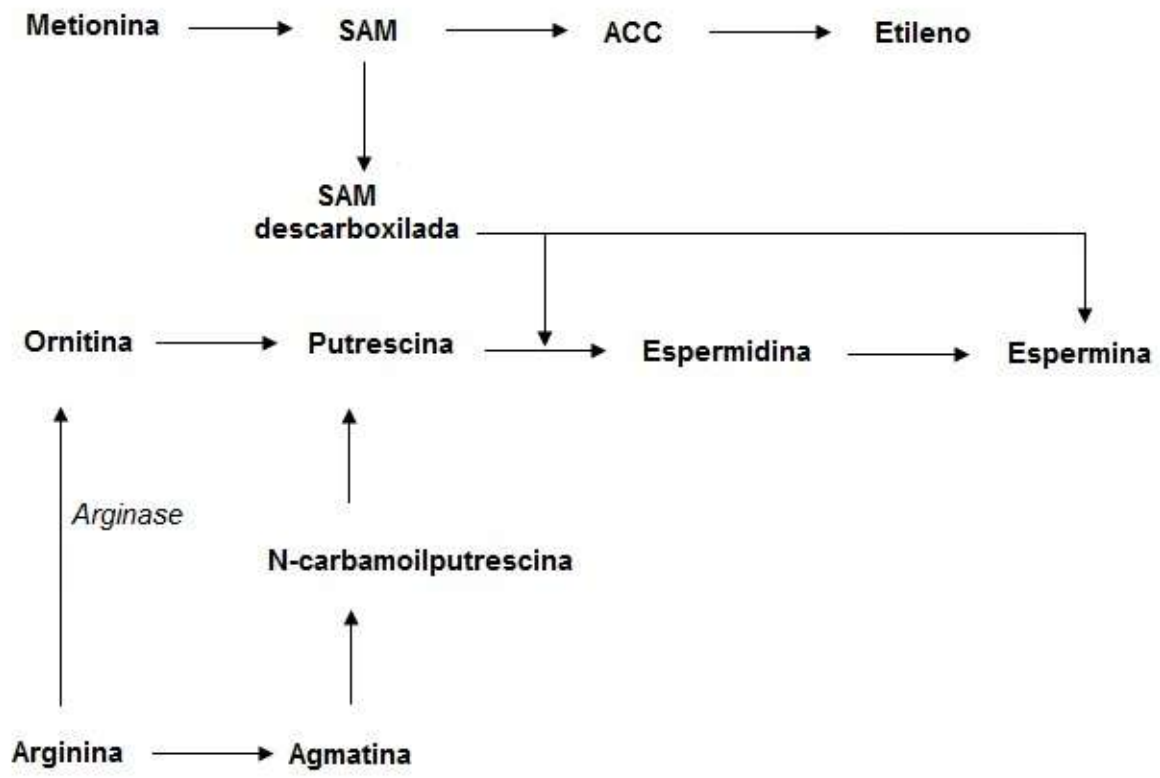

Figura 4 - Vias de síntese do etileno e das poliaminas, interligadas pela SAM descarboxilada.

As poliaminas estão presentes em bactérias e células vegetais e animais, atuando como moduladores da síntese protéica em diferentes níveis do processo (IGARASHI; KASHIWAGI, 2000; WALLACE; FRASER; HUGHES, 2003). Em plantas, as poliaminas podem ser encontradas livres ou conjugadas a compostos fenólicos. Quando conjugadas atuam no florescimento, síntese de metabólitos e respostas a 
infecções virais (BAIS; SUDHA; RAVISHANKAR, 2001).

Devido às suas cargas positivas, as poliaminas ligam-se a macromoléculas como DNA, RNA e proteínas participando da regulação da expressão gênica, proliferação celular, tradução, modulação da sinalização celular, estabilização da membrana e modulação de canais iônicos (KUSANO et al., 2008). Em plantas, as poliaminas estão envolvidas em inúmeros processos específicos, como desenvolvimento de órgãos reprodutores, tuberização, diferenciação da raiz, sensibilidade à radiação UV-C, proteção contra degradação de proteínas e desequilíbrio osmótico, entre outros (TAIZ; ZIEGER, 2002). A presença de 5 diferentes poliaminas foi investigada em 158 linhagens de bactérias pertencentes à família Azotobacteraceae e ao gênero Pseudomonas. Todas as linhagens produziram espermidina (Spd) e putrescina (Put) (GORIS; KERSTERS; DE VOS, 1998). Em Escherichia coli, as poliaminas podem ocorrer em grandes quantidades livres ou em complexos poliamina-RNA (IGARASHI; KASHIWAGI, 2000). E. coli e Pseudomonas aeruginosa têm seu crescimento consideravelmente reduzido quando suas vias de produção de Put e Spd são inibidas (BITONTI; McCANN; SJOERDSMA, 1982).

\subsection{FERTILIZAÇÃO NITROGENADA E SEU EFEITO SOBRE BEFN}

O suprimento de $\mathrm{N}$ é fundamental no controle da natureza e diversidade das plantas, na dinâmica das populações de animais e seus predadores e nos processos ecológicos vitais como produtividade agrícola, reciclagem de carbono e minerais. 
Na década de 1960, contínua e elevada aplicação de fertilizantes químicos, particularmente nitrogênio elevou grandemente a produção de cereais (VITOUSEK et al., 1997). Apesar desse aspecto positivo, ocorreram sérios impactos nos ecossistemas mundiais levando à poluição de estuários, de águas costeiras e lixiviação de solos, acelerando perdas de diversidade biológica. Plantas utilizam cerca de $50 \%$ do total de fertilizante aplicado às culturas, enquanto $25 \%$ são lixiviados, volatilizados ou desnitrificados causando perdas de até três bilhões de dólares à agricultura. A aplicação destes fertilizantes deve ser diminuída com o intuito de moderar seus efeitos. A manutenção destas práticas tornará a agricultura insustentável em pouco tempo. Além dos problemas de ordem ambiental, a produção de um quilograma de fertilizante nitrogenado consome grandes quantidades de energia fóssil. Elevados preços dos derivados de fósseis e a depleção das reservas de petróleo, impõem que novas estratégias para o suprimento de nitrogênio sejam pensadas (VITOUSEK et al., 1997; SAIKIA; JAIN, 2007). Uma alternativa apropriada é o adequado uso da fixação biológica do nitrogênio.

Atualmente há dados que mostram a interferência negativa da adubação nitrogenada sobre a microbiota endofítica fixadora de nitrogênio. Zhiyuan, Hurek e Reinhold-Hurek (2003) verificaram um forte efeito na composição de comunidades microbianas diazotróficas após a fertilização com N: rápida mudança na estrutura da população diazotrófica após 15 dias, marcado efeito sobre os genótipos de plantas e nas condições ambientais. Pariona-Llanos et al. (2007) mostrou que a cana-de-açúcar 
adubada organicamente apresentou maior número de bactérias endofíticas durante toda a safra (março a outubro) em pelo menos um órgão quando comparada com a adubação orgânica.

A adubação nitrogenada deve ser o mais equilibrada possível, pois de acordo com Alexander (1964) um excesso de suprimento de $\mathrm{N}$ causa um decréscimo na concentração de sacarose na planta reduzindo açúcares redutores e açúcares totais na cana-de-açúcar com conseqüente queda de qualidade além de causar alta incidência de mortalidade do caule (HUMBERT, 1968; CROCOMO et al., 1981).

Análises quantitativas de cana-de-açúcar submetida a baixos níveis de adubação estimaram um número acima de $10^{6}-10^{7}$ unidades formadoras de colônia de A diazotrophicus por grama de peso fresco. Só foi possível quantificar as bactérias quando as plantas foram cultivadas na ausência de fertilizantes nitrogenados industriais, e em presença de tratamentos orgânicos (MUTHUKUMARASAMY; REVATHI; LAKSHMINARASIMHAN, 1999). Todavia, a fertilização nitrogenada pode influir seletivamente dependendo da espécie bacteriana (DOS REIS JR et al., 2000).

Considerando que a agricultura seja uma das suas principais atividades de exportação, o Brasil tem liderado, entre todos os países, a prática da substituição de fertilizantes nitrogenados pela fixação biológica de nitrogênio e pode-se avaliar os resultados como muito bem sucedidos. Cereais selecionados associados com bactérias diazotróficas podem obter acima de $30 \%$ de seu N da Fixação Biológica de Nitrogênio 
quando fertilizados com PK e micro elementos (DÖBEREINER, 1997).

\subsection{AGRICULTURA ORGÂNICA}

As conseqüências antiecológicas da fertilização com $\mathrm{N}$ propiciaram o surgimento de propostas para a agricultura considerando aspectos agronômicos, ecológicos, sociais e econômicos (JUCKSCH; MENDONÇA; SANTOS, 2000). Uma das principais frentes de agricultura que contrapõem a este modelo agrícola é a agricultura orgânica. Esta corrente tem como objetivos gerar alimentos de alta qualidade biológica, trabalhando e respeitando o meio ambiente. As grandes diferenças entre este tipo de agricultura e o convencional são ausência de agrotóxicos, o fornecimento de fontes renováveis de macro e micronutrientes por meio de compostos orgânicos, que, aplicados a processos de rotação de culturas, proporcionam condições equilibradas entre o solo e os vegetais mantendo, assim, a biodiversidade.

Agricultura orgânica é um sistema de gerenciamento total da produção agrícola que exclui a adoção de substâncias químicas ou outros materiais sintéticos que desempenhem, no solo, funções estranhas às desempenhadas pelo ecossistema.

No Brasil atualmente, a taxa média de conversões para a agricultura orgânica é de $10 \%$ ao ano. A cultura orgânica está sendo desenvolvida com hortigranjeiros e com culturas anuais e perenes como cana-de-açúcar, milho etc. Resultados técnicos e econômicos mostraram que o sistema orgânico tem capacidade competitiva e sustentabilidade. Solos nativos onde se empregou a prática de cultura com conservação de resíduos (HALSALL, 1993) mostraram que a lignocelulose contida na 
palha de trigo poderia ser degradada por fungos, com um aumento de carbono orgânico no ambiente. Estas fontes de carbono são disponíveis a outros organismos como as bactérias diazotróficas cuja nitrogenase pode ser estimulada pelos fungos celulolíticos. Estes resultados podem explicar parcialmente porque resíduos retidos nos solos são transformados de modo a manter um suprimento adequado de nutrientes. Atualmente os estudos com sistemas alternativos de adubação estão evidenciando um aumento da expressão de genes específicos. Os resultados de Kumar et al. (2004) mostram um atraso na senescência das folhas e maior tolerância a doenças em pés de tomate. Certas proteínas relacionadas com o atraso da senescência mantiveram-se expressas por mais tempo nas plantas adubadas com um desses sistemas alternativos.

No Brasil, a aplicação da adubação orgânica em canaviais implica no retorno do bagaço da planta ao solo onde sua biodegradação é efetivada por organismos ali residentes. Dois fatos importantes são conseqüência da adubação orgânica: não havendo descarte do bagaço nos rios diminui-se a poluição ambiental e sua aplicação é menos dispendiosa por dispensar o uso dos fertilizantes obtidos a altos custos.

\subsection{CANA-DE-AÇÚCAR E SUA IMPORTÂNCIA PARA O BRASIL}

As culturas de cana no país apresentam uma característica notável: apesar de serem cultivadas por centenas de anos, os solos recebem pouca aplicação de adubação nitrogenada, cerca de $80 \mathrm{Kg} \cdot \mathrm{h}^{-1}$ por ano (BODDEY et al., 2004). Canaviais da região de Sertãozinho, estado de São Paulo, recebem aplicação de $93 \mathrm{Kg} \cdot \mathrm{h}^{-1}$ por ano (comunicação pessoal) $)^{1}$. 
1 - Dados obtidos com Fernando Alonso, Engenheiro Agrônomo da Usina São Francisco em reunião realizada durante a elaboração do projeto.

Os genótipos de cana-de-açúcar desenvolvidos atualmente apresentam as maiores contribuições de nitrogênio fixado biológicamente entre todas as não leguminosas (DÖBEREINER, 1997). O grande número de bactérias fixadoras de $\mathrm{N}_{2}$ endofíticas associadas à cana-de-açúcar presentes em caules, raízes e folhas sugere que possa haver vários tipos de interação entre os parceiros. Esta particularidade nutricional é de fundamental importância, pois, sob o prisma microbiológico, está diretamente relacionada com interações entre bactérias e as plantas, particularmente bactérias fixadoras de nitrogênio. Atualmente a interação entre os genótipos selecionados é responsável pela maior contribuição da fixação biológica de nitrogênio obtida entre todos os não legumes (DÖBEREINER, 1997).

A produção canavieira representa uma das maiores contribuições financeiras ao Brasil. Esta cultura ocupa hoje, 8091,5 hectares do território nacional. A safra 2009/2010, teve uma produção total de 604,5 milhões de toneladas de cana-de-açúcar e espera-se que esse número aumente em quase $10 \%$ para a próxima safra. Estima-se que sejam produzidas cerca de 360 e 301 milhões de toneladas de etanol e açúcar respectivamente (COMPANHIA NACIONAL DE ABASTECIMENTO, 2010).

O grande número de bactérias fixadoras de $\mathrm{N}_{2}$ endofíticas associadas à cana- 
de-açúcar presentes em caules, raízes e folhas sugere que possa haver vários tipos de interação entre os parceiros. Uma das vantagens para a cana-de-açúcar poderia ser a liberação de fitoquímicos. Considerando que o tipo de adubação interfere inclusive em níveis moleculares, pode-se supor que a produção de substâncias ativas em plantas seja alterada de acordo com o tipo de fertilização ou sua ausência.

Cada vez mais o homem anseia por um modelo de agricultura sustentável. Alguns exemplos apontam para esta possibilidade com a utilização de agricultura orgânica e a fixação biológica de nitrogênio. Sesamum indicum L. não apresentou diferença de crescimento quando cultivada sob a dose normal de adubo convencional ou sob dose reduzida pela metade de fertilizante aliada à inoculação com Pseudomonas (KUMAR; PANDEY; MAHESHWARI, 2009). Pela grande importância que a cana-de-açúcar representa para o Brasil e pela presença constante de bactérias fixadoras de nitrogênio nesta cultura é de se supor a existência de uma estreita relação entre esta gramínea e estes microrganismos. Consequentemente, há uma grande necessidade de aumentar os conhecimentos sobre os mecanismos envolvidos nas interações. Por outro lado, a ausência de dados sobre os efeitos da adubação orgânica em cana-de-açúcar é um impulso para se propor pesquisas que estudem as BEFN isoladas de cana-de-açúcar submetidas a este tipo de adubação e os compare com dados obtidos com BENF isoladas de cana-de-açúcar submetidas a fertilizantes com os já estabelecidos níveis de $\mathrm{N}$ mineral e a cana-de-açúcar sem adubação.

Embora estudos em cultura pura não reflitam obrigatoriamente a fisiologia do 
microrganismo quando em seu habitat natural, poderão fornecer dados altamente favoráveis para o conhecimento das potencialidades dos microrganismos. Culturas puras podem evidenciar a produção de substâncias estimulantes ou inibidoras de atividades celulares, como aminoácidos, poliaminas e fitormônios, que secretadas ao meio, definem a importância da associação estabelecida entre microrganismo e planta. Apesar da importância dos endofíticos na produção de fitoquímicos, não há dados na literatura que demonstrem que a fertilização nitrogenada possa afetar sua síntese pelos microrganismos. Por outro lado, o teste de redução de acetileno, indica se a nitrogenase bacteriana, está sendo expressa concomitantemente à produção dos aminoácidos e fitoquímicos.

Os resultados a serem obtidos sobre a liberação dessas substâncias, se relacionadas à presença de BENF na cana-de-açúcar, poderão ser vinculadas a aspectos ecológicos e fornecer subsídios e critérios para aplicações em diferentes níveis.

Finalmente, este estudo poderá trazer grandes contribuições para o setor sucroalcooleiro, fornecendo dados para a exploração planejada de setores ainda não ocupados, para a projeção de novas técnicas que levem a um aumento de produtividade e outros possíveis benefícios. 


\section{MATERIAL E MÉTODOS}

\subsection{MATERIAL BIOLÓGICO}

Neste trabalho foram utilizadas 36 linhagens de bactérias endofíticas diazotróficas isoladas de cana-de-açúcar, escolhidas aleatoriamente da coleção de culturas do nosso laboratório. As plantas eram oriundas de canaviais submetidos a três tratamentos: fertilização orgânica, fertilização convencional e sem fertilização, sendo 12 linhagens bacterianas de cada tipo. A Tabela 1 mostra a relação dos microrganismos estudados e o tipo de adubação aplicado à cana-de-açúcar da qual foram isoladas.

\begin{tabular}{|c|c|c|}
\hline & & \\
\hline Orgânico & Convencional & Controle \\
\hline ICB21 (11/2000) & ICB365 (07/2003) & ICB386 (10/2003) \\
\hline ICB22 (11/2000) & ICB369 (07/2003) & ICB397 (07/2004) \\
\hline ICB101 (09/2001) & ICB371 (07/2003) & ICB405 (07/2004) \\
\hline ICB105 (09/2001) & ICB375 (07/2003) & ICB409 (07/2004) \\
\hline ICB115 (09/2001) & ICB379 (07/2003) & ICB439 (08/2004) \\
\hline ICB117 (09/2001) & ICB383 (07/2003) & ICB464 (08/2004) \\
\hline ICB118 (09/2001) & ICB479 (11/2004) & ICB565 (07/2007) \\
\hline ICB508 (05/2005) & ICB481 (11/2004) & ICB567 (07/2007) \\
\hline ICB522 (08/2005) & ICB551 (04/2006) & ICB568 (07/2007) \\
\hline ICB525 (08/2005) & ICB553 (04/2006) & ICB569 (07/2007) \\
\hline ICB528 (08/2005) & ICB557 (04/2006) & ICB572 (07/2007) \\
\hline ICB532 (08/2005) & ICB561 (04/2006) & ICB573 (07/2007) \\
\hline
\end{tabular}


Os isolados ICB456 (coletado em 08/2004) e ICB493, ICB494, ICB500, ICB503, ICB504 e ICB506 (coletados em 11/2004) identificados como Rhizobium sp. em outra fase do projeto realizado em nosso laboratório, foram submetidos à identificação no nível de espécie por Multi Locus Sequence Analysis (MLSA) dos genes 16S rRNA, gapA e recA.

Para os estudos de MLSA foram usadas as linhagens tipo das seguintes espécies bacterianas: Rhizobium tropici (DSMZ11418), Rhizobium etli (DSMZ11541), Rhizobium galegae (DSMZ11542), Rhizobium hainanense (DSMZ11917), Rhizobium sullae (DSMZ14623), Rhizobium leguminosarum (DSMZ30132), Rhizobium phaseoli (DSMZ30137), Rhizobium trifolii (DSMZ30141), Rhizobium radiobacter (DSMZ30147) e Rhizobium rhizogenes (DSMZ30148) compradas da empresa Deutsche Sammlung von Mikroorganismen und Zellkulturen (DSMZ).

\subsection{ADUBAÇÃO}

As plantas de cana-de-açúcar, das variedades SP791011 e SP801816, de onde foram isoladas as bactérias do presente estudo, foram cultivadas no município de Sertãozinho, estado de São Paulo, Brasil ( $\left.21^{\circ} 9^{\prime} \mathrm{S} ; 48^{\circ} 9^{\prime} \mathrm{N}\right)$. Três areas adjacentes, cada uma submetida a um tipo de adubação, de latossolo roxo, foram escolhidas como sítio de coleta. O ph do solo apresentava-se entre 6.0 e 7.0. A dubação da cana-deaçúcar foi realizada uma vez, imediatamente após o corte ca cultura anterior. A fertilização orgânica consistiu na aplicação de $100 \mathrm{~m}^{3} \cdot \mathrm{ha}^{-1}$ de vinhaça (80 kg de N e 300 
$\mathrm{kg}$ de K), torta de filtro, rocha fosfatada e rocha basaltica. Para a aplicação da fertilização convencional utilizaram-se $465 \mathrm{~kg} \cdot \mathrm{ha}^{-1}$ of NPK fertilizer 20-0-20 (93 kg.ha-1 of $\mathrm{N}$ and $\mathrm{K}$ ). A fertilização orgânica utilizada foi certificada pelas agências internacionais: IFOAM - International Federation of Organic Agriculture Movements (1997); ECOCERT International, agência de certificação Franco-Germânica (1999); e pela International Certification Services of Japan (2000).

\subsection{MEIOS DE CULTURA}

- meios JNFb, NFb, LGI e LGD (Tabela 2) foram utilizados para manutenção, preservação e contagem de UFC das diferentes bactérias. Esses meios foram usados distintamente, respeitando o meio em que cada bactéria foi isolada.

- meio MS - para culturas de células vegetais (MURASHIGE; SKOOG, 1962). Utilizado para a determinação das curvas de crescimento e da produção de aminoácidos, poliaminas e fitormônios. Meio MS (em mg.l-1): $\mathrm{NH}_{4} \mathrm{NO}_{3}$ (1650); $\mathrm{KNO}_{3}$ (1900); $\mathrm{H}_{3} \mathrm{BO}_{3}(6,2) ; \mathrm{KH} 2 \mathrm{PO} 4(170,0) ; \mathrm{KI}(0,83) ; \mathrm{Na}_{2} \mathrm{MoO}_{4} \cdot 2 \mathrm{H}_{2} \mathrm{O}(0,25) ; \mathrm{CoCl}_{2} \cdot 6 \mathrm{H}_{2} \mathrm{O}$ (0,025); $\mathrm{CaCl}_{2} \cdot 2 \mathrm{H}_{2} \mathrm{O}(440,0) ; \mathrm{MnSO}_{4} \cdot 4 \mathrm{H}_{2} \mathrm{O}(22,3) ; \mathrm{MgSO}_{4} \cdot 7 \mathrm{H}_{2} \mathrm{O}(370,0) ; \mathrm{CuSO}_{4} \cdot 5 \mathrm{H}_{2} \mathrm{O}$ (0,025); $\mathrm{ZnSO}_{4} .7 \mathrm{H}_{2} \mathrm{O}$ (8,6); $\mathrm{Na}_{2} \operatorname{EDTA}(37,3) ; \mathrm{FeSO}_{4}$ (27,8); Glicina (Gly) (2,0); Ácido nicotínico (0,5); Piridoxina (0,5); Tiamina (0,1); Mio-Inositol (100); Sacarose (20); 2,4,D $(3,0)$. Meio MS modificado (MMS): isento de fonte de $\mathrm{N}$ combinado, usado em experimentos em que deveria ocorrer a fixação de nitrogênio. As produções de ácido indol-3-acético e de etileno foram testadas em meio MMS contendo como precursores, respectivamente: $0,50{\mathrm{~g} . \mathrm{I}^{-1}}^{1}$ de triptofano (Trp) e 0,40 $\mathrm{g}^{.-1}$ de metionina (Met) (THULER et al., 2003a). 
Os meios semi-sólidos são acrescidos de 1,8 g..$^{-1}$ de ágar e os meios sólidos, de

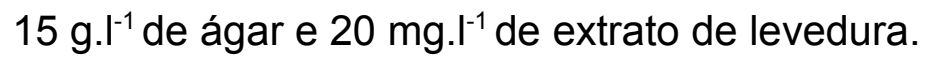

Tabela 2 - Meios de cultura (em g..$^{-1}$ ) para bactérias fixadoras de nitrogênio

\begin{tabular}{|c|c|c|c|c|c|}
\hline Componentes & NFb & JNFb & LGD & LGI & LGIP \\
\hline Glicose & -- & -- & 20 & -- & -- \\
\hline Sacarose & -- & -- & -- & 5 & 100 \\
\hline Ácido Málico & 5 & 5 & -- & -- & -- \\
\hline $\mathrm{K}_{2} \mathrm{HPO}_{4}$ & 0,5 & 0,6 & 0,05 & 0,2 & 0,2 \\
\hline $\mathrm{KH}_{2} \mathrm{PO}_{4}$ & -- & 1,8 & 0,15 & 0,6 & 0,6 \\
\hline $\mathrm{CaCl}_{2}$ & -- & -- & 0,01 & -- & -- \\
\hline $\mathrm{CaCl}_{2} .2 \mathrm{H}_{2} \mathrm{O}$ & 0,02 & 0,02 & -- & 0,02 & 0,02 \\
\hline $\mathrm{MgSO}_{4} \cdot 7 \mathrm{H}_{2} \mathrm{O}$ & 0,2 & 0,2 & 0,2 & 0,2 & 0,2 \\
\hline $\mathrm{Na}_{2} \mathrm{MoO}_{4} \cdot 2 \mathrm{H}_{2} \mathrm{O}$ & 0,002 & 0,002 & 0,002 & 0,002 & 0,002 \\
\hline $\mathrm{FeCl}_{3} .2 \mathrm{H}_{2} \mathrm{O}$ & -- & -- & 0,01 & -- & 0,01 \\
\hline $\begin{array}{l}\text { Azul de Bromotimol } \\
(0,5 \% \text { em } 2 \mathrm{~N} \text { de } \mathrm{KOH})\end{array}$ & $2 \mathrm{ml}$ & $2 \mathrm{ml}$ & -- & $5 \mathrm{ml}$ & $5 \mathrm{ml}$ \\
\hline $\mathrm{NaHCO}_{3}$ & -- & -- & 0,01 & -- & -- \\
\hline $\mathrm{NaCl}$ & 0,1 & 0,1 & -- & -- & -- \\
\hline FeEDTA (sol. 1,64\%) & $4 \mathrm{ml}$ & $4 \mathrm{ml}$ & -- & $4 \mathrm{ml}$ & $4 \mathrm{ml}$ \\
\hline $\mathrm{KOH}$ & 4,5 & 4,5 & -- & -- & -- \\
\hline $\mathrm{CuSO}_{4} .5 \mathrm{H}_{2} \mathrm{O}$ & 0,00008 & 0,00008 & -- & -- & -- \\
\hline $\mathrm{ZnSO}_{4} .7 \mathrm{H}_{2} \mathrm{O}$ & 0,0024 & 0,0024 & -- & -- & -- \\
\hline $\mathrm{H}_{3} \mathrm{BO}_{3}$ & 0,0028 & 0,0028 & -- & -- & -- \\
\hline $\mathrm{MnSO}_{4} .7 \mathrm{H}_{2} \mathrm{O}$ & 0,00235 & 0,00235 & -- & -- & -- \\
\hline Biotina & 0,00001 & 0,00001 & -- & 0,00001 & 0,00001 \\
\hline Piridoxol-HCl & 0,00002 & 0,00002 & -- & 0,00002 & 0,00002 \\
\hline $\mathrm{pH}$ & $6,5-6,8$ & 5,8 & 7,0 & 6,0 & 6,0 \\
\hline
\end{tabular}

Fonte: Döbereiner, Baldani e Baldani (1995). 


\subsection{SOLUÇÕES}

\subsubsection{Eluentes para HPLC}

4.4.1.1 Análise de aminoácidos:

Eluente A - Acetato de Sódio $\left(4,10 \mathrm{g.l}^{-1}\right)$, fosfato de sódio $\left(8,96 \mathrm{~g} \mathrm{.l}^{-1}\right)$, tetrahidrofurano $0,2 \%$ e metanol $0,2 \%$ em água deionizada.

Eluente B - metanol $65 \%$ em água deionizada.

4.4.1.2 Análise de poliaminas:

Eluente $\mathrm{A}$ - Acetonitrila 10\% em água deionizada com pH ajustado para 3,5 com $\mathrm{HCl} 1 \mathrm{~N}$.

Eluente B - Acetonitrila 100\%.

4.4.1.3 Análise de AIA:

Eluente A - Metanol 10\%, Ácido acético 0,5\% em água deionizada. Eluente B - metanol 100\%

\subsubsection{Solução OPA-Borato}

Contém $140 \mathrm{mg}$ de OPA; $18,2 \mathrm{ml}$ de tampão borato $\mathrm{pH}=9,5 ; 166,2 \mu \mathrm{l}$ de $\beta$ mercaptoetanol e 2,8 $\mathrm{ml}$ de metanol, usada para derivatização de aminoácidos.

\subsubsection{Solução para banho de brometo de etídio}


Em $100 \mathrm{ml}$ de $\mathrm{H}_{2} \mathrm{O}$ destilado foram adicionados $5,0 \mu \mathrm{l}$ de solução de brometo de etídio $10 \mathrm{mg} \cdot \mathrm{ml}^{-1}$ (Bio Basic Inc.).

\subsubsection{Solução de EDTA 0,5 M}

Foram pesados $9,3 \mathrm{~g}$ de Ácido etilenodiamino tetra-acético e dissolvidos em 40 $\mathrm{ml}$ de agua deionizada. $\mathrm{O} \mathrm{pH}$ foi ajustado para $8,0 \mathrm{com} \mathrm{NaOH}$. A solução foi esterilizada em autoclave e seu volume foi ajustado para $50 \mathrm{ml}$.

\subsubsection{Tampão TAE 50X}

Para a solução estoque de TAE (Tris-Ácido acético-EDTA) 24 g de Tris $\mathrm{HCl}(1,0$ M) foram dissolvidos em $75 \mathrm{ml}$ de água deionizada. Cuidadosamente foram adicionados 5,7 ml de ácido acético glacial e $10 \mathrm{ml}$ de EDTA (0,5 M). O volume final da solução foi ajustado para $100 \mathrm{ml}$.

Para a preparação do gel de agarose $1 \%$ utilizou-se $100 \mathrm{ml}$ do tampão TAE diluido para 1X (10 ml de TAE em $490 \mathrm{ml}$ de $\mathrm{H}_{2} \mathrm{O}$ destilada).

\subsection{METODOLOGIA}

\subsubsection{Testes fisiológicos}

4.5.1.1 Crescimento das culturas para determinações de AIA, etileno, aminoácidos e poliaminas excretados ao meio pelas bactérias

Inóculos de culturas puras, incubados sob agitação por 16h, em meio líquido, específico para o melhor crescimento de cada bactéria, acrescido de $1,32{\mathrm{~g} . \mathrm{l}^{-1}} \mathrm{de}$ 
$\left(\mathrm{NH}_{4}\right)_{2} \mathrm{SO}_{4}$ foram diluidos 1/100. Cem microlitros dessas diluições foram semeados em $150 \mathrm{ml}$ de meio MS líquido isento de nitrogênio combinado (com ou sem precursor, conforme o caso) e incubados em estufa a $30^{\circ} \mathrm{C}$ sem agitação. Após 5, 24, 100 e 200 horas de crescimento, alíquotas de $10 \mathrm{ml}$ foram centrifugadas (14000 rcf por 30min). Após passagem por filtros Millipore $(0,22 \mu \mathrm{m})$, os sobrenadantes foram usados para a detecção de aminoácidos, AIA e poliaminas. Simultaneamente foram retiradas amostras das culturas para contagem de Unidades Formadoras de Colônias (UFC) pelo método da gota (BARBOSA et al., 1995).

\subsection{Aminoácidos}

Os aminoácidos contidos no sobrenadante das culturas foram submetidos à técnica da derivatização com O-ftalaldeído (OPA), segundo a metodologia descrita por Astarita, Floh e Handro (2004) adaptada para dosagem de aminoácidos em culturas bacterianas. Misturou-se $400 \mu \mathrm{l}$ da solução OPA-borato e $200 \mu \mathrm{l}$ da amostra. Os aminoácidos derivatizados foram identificados e quantificados por cromatografia líquida de alto desempenho em HPLC de fase reversa com coluna C18 (Shimadzu Shim-pack CLC ODS) e detector de fluorescência (excitação 250 nm e emissão de $480 \mathrm{~nm}$ ). As concentrações dos eluentes na coluna foram $80 \%$ do Eluente A e $20 \%$ do Eluente B nos primeiros $32 \mathrm{~min}$ de corrida. Entre 32 e $71 \mathrm{~min}$ a concentração do Eluente B aumentou linearmente de 20\% para 100\% sendo mantida até 93min (fim da análise). As áreas, tempos de retenção e concentração de cada aminoácido foram avaliados por comparação com padrões de concentrações conhecidas.

\subsection{Poliaminas}


As poliaminas solúveis putrescina, espermidina, espermina e cadaverina foram analisadas segundo a metodologia descrita por Silveira et al. (2004) adaptada para dosagem de poliaminas em meio de cultura bacteriana. As poliaminas foram derivatizadas misturando-se $40 \mu \mathrm{l}$ da amostra do sobrenadante a $100 \mu \mathrm{l}$ de cloreto de dansil $\left(5 \mathrm{mg} \cdot \mathrm{ml}^{-1}\right), 50 \mu \mathrm{l}$ de solução saturada de $\mathrm{NaHCO}_{3}$ e $20 \mu \mathrm{l}$ de 1,7diaminoheptano. Após a mistura, as amostras foram incubadas por $50 \mathrm{~min}$ a $70^{\circ} \mathrm{C}$. Com a adição de $25 \mu \mathrm{l}$ de prolina (100 $\mathrm{mg}^{\mathrm{ml}} \mathrm{l}^{-1}$ ), o excesso do cloreto de dansil foi convertido em dansil-prolina incubando-se por 30min à temperatura ambiente. Em seguida, as poliaminas derivatizadas foram particionadas com $200 \mu \mathrm{l}$ de tolueno. A fase apolar foi coletada $(175 \mu \mathrm{l})$, seca sob jato de nitrogênio e ressuspendida em $175 \mu \mathrm{l}$ de acetonitrila. A identificação e quantificação das poliaminas foram realizadas em HPLC, utilizando-se uma coluna C18, fase reversa (Shimadzu Shim-pack CLC ODS) e detector de fluorescência (excitação 340 nm e emissão de 510 nm). As concentrações dos eluentes usadas foram $35 \%$ do Eluente A e $65 \%$ do Eluente B por 11 min seguida de um aumento linear da concentração do Eluente B para 100\% entre 11 e 25min, sendo assim mantida por mais $10 \mathrm{~min}$, até o final da análise. As áreas dos picos, os tempos de retenção e a concentração de cada poliamina, foram identificados e quantificados comparando-se com seus padrões. As perdas foram medidas comparando-se a concentração inicial e final de 1,7-diaminoheptano.

\subsection{AlA}

Este composto foi analisado pela metodologia de Kojima (1996) adaptada para dosagem em culturas de microrganismos. Para determinar o rendimento da amostra foram adicionados, em $5 \mathrm{ml}$ do sobrenadante, $100 \mu \mathrm{l}$ de $\left[{ }^{3} \mathrm{H}\right] \mathrm{AlA}$ radioativo como padrão 
interno. As amostras foram particionadas em funil de separação, com éter dietílico; a fase orgânica foi seca em "speed vac" e ressuspendida em $300 \mu \mathrm{l}$ de metanol 100\%. A quantificação de AIA foi realizada em HPLC de fase reversa, com coluna C18 (Shimadzu Shim-pack CLC ODS) e detector de fluorescência (excitação $280 \mathrm{~nm}$ e emissão de $350 \mathrm{~nm}$ ). Foram injetados, na coluna, $40 \mu \mathrm{l}$ da amostra. A estimativa de perdas foi avaliada, por cintilação, através da determinação da radioatividade das amostras. A cintilação foi realizada em cintilador (Beckman - LC6502) leitura para trítio $=3 \mathrm{~min}$ utilizando-se $1,0 \mathrm{ml}$ da amostra recolhida no coletor de frações misturada a $4 \mathrm{ml}$ de líquido de cintilação.

\subsection{Etileno}

Culturas, feitas em meio MMS acrescido de metionina, contidas em frascos tipo penicilina, tampados com rolha de borracha e lacre de alumínio, foram incubadas a 30 ${ }^{\circ} \mathrm{C}$ por $220 \mathrm{~h}$. Após 144 e 220h, 1,0 ml da fase aérea foi retirado e analisado em cromatógrafo a gás Shimadzu GC-14A, com coluna Porapak-N 80/100 - INOX a $70{ }^{\circ} \mathrm{C}$, injetor a $180{ }^{\circ} \mathrm{C}$ e detector a $230{ }^{\circ} \mathrm{C}$ (THULER et al., 2003a). As concentrações das amostras foram calculadas utilizando-se as áreas dos padrões com concentrações conhecidas.

\subsubsection{Quantificação bacteriana}

Das mesmas culturas puras usadas para as determinações de aminoácidos, poliaminas e AIA, $0,1 \mathrm{ml}$ foi submetido à diluição seriada e plaqueamento para contagem de Unidades Formadoras de Colônia (UFC). A alíquota foi retirada da cultura em meio MMS e as diluições plaqueadas nos meios específicos, em que a bactéria foi 
isolada, utilizando o método da gota (BARBOSA et al., 1995). Seis gotas de $25 \mu l$ de cada diluição foram plaqueadas. A média do número de UFC dessas seis gotas foi multiplicada por 40 e dividida pela diluição correspondente para se obter a quantidade de UFC.ml-1 na cultura.

4.5.1.3 Medida da atividade específica da nitrogenase. Teste quantitativo de redução de acetileno

Simultaneamente à retirada das amostras usadas para avaliação do crescimento, foram retirados, em triplicata, $8,0 \mathrm{ml}$ de cultura que foram colocados em frascos tipo penicilina de $15 \mathrm{ml}$ vedados com tampa de borracha e lacre de alumínio. A fase aérea teve $10 \%$ de seu volume substituído por acetileno e os frascos foram incubados a $30^{\circ} \mathrm{C}$ por $24 \mathrm{~h}$. A produção de etileno foi testada quantitativamente injetando-se $0,1 \mathrm{ml}$ da fase aérea em cromatógrafo a gás Shimadzu GC-14A, com coluna Porapak-N 80/100 - INOX a $70^{\circ} \mathrm{C}$, injetor a $180{ }^{\circ} \mathrm{C}$ e detector a $230^{\circ} \mathrm{C}$ (ANDERSON et al., 2004). As concentrações das amostras foram calculadas comparando-se com curva padrão de etileno.

\subsubsection{Testes moleculares}

\subsubsection{Extração do DNA Genômico}

Para a extração do DNA das linhagens tipo e ambientais foram preparados inóculos em Caldo Nutriente crescidos "overnight" sob agitação. Seguiu-se o protocolo de "Wizard Genomic DNA Purification Kit", catálogo número \#A1120 (Promega) de acordo com as instruções do fabricante. A qualidade da extração de DNA foi verificada 
através de eletroforese em gel de agarose $(1,0 \%)$ (Invitrogen) seguida por imersão em solução de brometo de etídio por $15 \mathrm{~min}$.

As concentrações dos DNAs foram medidas no equipamento NanoDrop 1000 Spectrometer (Thermo Scientific) e diluídas em água deionizada para concentração final de $100 n g \cdot \mu^{-1}$.

\subsubsection{Amplificação dos fragmentos}

Para a amplificação dos genes $16 \mathrm{~S}$ rRNA, gapA e recA foi utilizado o método de Reação em Cadeia da Polimerase (PCR). Para cada reação utilizou-se $25 \mu \mathrm{l}$ de Master $\operatorname{Mix}^{\circledast}$ (Promega), $20 \mu$ de água deionizada “DNAse Free", $1 \mu$ de DNA bacteriano e $2 \mu l$ de cada primer ("forward" e "reverse") específico para os genes estudados (Tabela 3).

Pra a amplificação do gene $16 \mathrm{~S}$ rRNA utilizou-se a temperatura de $95^{\circ} \mathrm{C}$ por $2 \mathrm{~min}$ seguido por 40 ciclos de $95{ }^{\circ} \mathrm{C}$ por 1 min para a denaturação, $56^{\circ} \mathrm{C}$ por $1 \mathrm{~min}$ para 0 anelamento e $72{ }^{\circ} \mathrm{C}$ POR 1 min para a extensão do DNA. Após o término dos ciclos realizou-se uma etapa de $10 \mathrm{~min}$ a $72^{\circ} \mathrm{C}$ para a estabilização do DNA.

A amplificação dos genes gapA e recA foi feita com o protocolo de temperaturas de $92{ }^{\circ} \mathrm{C}$ por 5 min seguido de 40 ciclos de $92{ }^{\circ} \mathrm{C}$ por $2 \mathrm{~min}$ para a denaturação, $50^{\circ} \mathrm{C}$ por 2 min e 15 s para o anelamento e $72{ }^{\circ} \mathrm{C}$ por 1 min e 15 s para a extensão do DNA. Após o término dos ciclos realizou-se uma etapa de $10 \mathrm{~min}$ a $72^{\circ} \mathrm{C}$ para a estabilização do DNA. 


\begin{tabular}{|c|c|c|c|c|}
\hline "Primer" & Sequencia $\left(5^{\prime}-3^{\prime}\right)$ & Gene alvo & Utilização & Referência \\
\hline $27 f$ & AGAGTTTGATCCTGGCTCAG & 16S rRNA & $\begin{array}{c}\text { Amplificação e } \\
\text { sequenciamento }\end{array}$ & $\begin{array}{c}\text { Weisburg et } \\
\text { al., } 1991\end{array}$ \\
\hline $536 f$ & CAGCMGCCGCGGTAATWC & 16S rRNA & Sequenciamento & $\begin{array}{c}\text { Holben et al., } \\
2004\end{array}$ \\
\hline $782 r$ & ACCAGGGTATCTAATCCTGT & 16S rRNA & Sequenciamento & $\begin{array}{l}\text { Chimetto et } \\
\text { al., } 2008\end{array}$ \\
\hline $1492 r$ & GGTTACCTTGTTACGACTT & $16 S$ rRNA & $\begin{array}{c}\text { Amplificação e } \\
\text { sequenciamento }\end{array}$ & $\begin{array}{l}\text { Weisburg et } \\
\text { al., } 1991\end{array}$ \\
\hline gapAf & CGGTCCGGTCGAGACCAA & gapA & $\begin{array}{c}\text { Amplificação e } \\
\text { sequenciamento }\end{array}$ & $\begin{array}{l}\text { van Berkun } \\
\text { et al., } 2006\end{array}$ \\
\hline gapAr & CGGTAGAGATCCTTGTGCAT & gapA & $\begin{array}{l}\text { Amplificação e } \\
\text { sequenciamento }\end{array}$ & $\begin{array}{l}\text { van Berkun } \\
\text { et al., } 2006\end{array}$ \\
\hline recAf & CCGGTTCGCTCGGCCTCGATA & recA & $\begin{array}{c}\text { Amplificação e } \\
\text { sequenciamento }\end{array}$ & $\begin{array}{l}\text { van Berkun } \\
\text { et al., } 2006\end{array}$ \\
\hline recAr & CGCCCATCTCGCCCTCGATTT & recA & $\begin{array}{c}\text { Amplificação e } \\
\text { sequenciamento }\end{array}$ & $\begin{array}{l}\text { van Berkun } \\
\text { et al., } 2006\end{array}$ \\
\hline
\end{tabular}

\subsubsection{Purificação dos produtos de PCR}

Os produtos amplificados foram purificados com "GFX'M PCR DNA and Gel Band Purification Kit", catálogo $n^{\circ}$ 27-9602-01 (GE Healthcare), seguindo instruções do fabricante.

\subsubsection{Reação de Seqüenciamento}

Os produtos purificados com GFX ${ }^{\mathrm{TM}}$ foram submetidos à reação de seqüenciamento dos genes gapA, recA e 16S rRNA das linhagens tipo e isolados ambientais. As reações de seqüenciamento foram realizadas seguindo o protocolo do 
kit "DYEnamic ${ }^{\mathrm{TM}}$ ET dye terminator kit" (MegaBACE ${ }^{\mathrm{TM}}$ ), catálogo nUS81090 Amersham Biosciences/GE Healthcare com 5 pmoles de "primer" e $4 \mu \mathrm{l}$ de DYE ET. As concentrações de produtos amplificados utilizados nas reações de sequenciamento variaram de acordo com o tamanho do fragmento em análise. As temperaturas foram de $95{ }^{\circ} \mathrm{C}$ por $20 \mathrm{~s} ; 50-55^{\circ} \mathrm{C}$ por $15 \mathrm{~s}$ e $60{ }^{\circ} \mathrm{C}$ por um minuto. Os ciclos foram repetidos por 30 ou 45 vezes.

\subsubsection{Análises Filogenéticas}

Após a reação de seqüenciamento, os dados brutos foram capturados e a análise de qualidade e obtenção das seqüências "contig" ou "consenso" foram realizadas utilizando o programa "Chromas Pro Current Version 1:34". Após obtenção das seqüências consenso, as linhagens foram exportadas em formato FASTA para inferência filogenética. O alinhamento das seqüências do gene 16S rRNA, a geração da matriz de similaridade e a construção da árvore filogenética dos 36 isolados submetidos aos testes fisiológicos foram realizadas através do programa Bionumerics $^{\mathrm{TM}}$. O alinhamento das sequencias concatenadas dos genes recA, gapA e 16S rRNA, a geração da matriz de similaridade e a construção da árvore filogenética das linhagens de Rhizobium sp. foram feitas através do programa Molecular Evolutionary Genetics Analysis (MEGA 4.1).

\subsubsection{Análise estatística}

Os dados foram analisados por ANOVA $(P<0,05)$ seguido por teste de KruskalWallys $(P<0,05)$ e teste de análise de proporções. 


\section{RESULTADOS}

\subsection{IDENTIFICAÇÃO E FILOGENIA}

A tabela 4 apresenta as identificações dos microrganismos estudados no presente trabalho.

Tabela 4 - Identificação dos 12 isolados de cana-de-açúcar, submetida à fertilização orgânica, convencional ou sem adubação, obtida por sequenciamento do gene 16S rRNA.

\begin{tabular}{lll}
\hline \multicolumn{1}{c}{ Orgânico } & \multicolumn{1}{c}{ Convencional } & \multicolumn{1}{c}{ Controle } \\
\hline ICB21 Herbaspirillum sp. & ICB365 Klebsiella sp. & ICB386 Rhizobium sp. \\
ICB22 Enterobacter sp. & ICB369 Klebsiella sp. & ICB397 Grimontella sp. \\
ICB101 Enterobacter sp. & ICB371 Pseudomonas sp. & ICB405 Enterobacter sp. \\
ICB105 Enterobacter sp. & ICB375 Klebsiella sp. & ICB409 Erwinia sp. \\
ICB115 Klebsiella sp. & ICB379 Chryseobacterium sp. & ICB439 Enterobacter sp. \\
ICB117 Acinetobacter sp. & ICB383 Pseudomonas sp. & ICB464 Enterobacter sp. \\
ICB118 Enterobacter sp. & ICB479 Enterobacter sp. & ICB565 Klebsiella sp. \\
ICB508 Herbaspirillum sp. & ICB481 Enterobacter sp. & ICB567 Enterobacter sp. \\
ICB522 Enterobacter sp. & ICB551 Enterobacter sp. & ICB568 Herbaspirillum sp. \\
ICB525 Enterobacter sp. & ICB553 Klebsiella sp. & ICB569 Enterobacter sp. \\
ICB528 Enterobacter sp. & ICB557 Gluconoacetobacter sp. & ICB572 Klebsiella sp. \\
ICB532 Klebsiella sp. & ICB561 Enterobacter sp. & ICB573 Enterobacter sp. \\
\hline
\end{tabular}

A filogenia dos isolados, levando-se em conta a análise do gene 16S rRNA, está representada na figura 5. Nela são verificados dois grupos distintos de enterobactérias. O primeiro formado pelas linhagens: de Enterobacter sp. - ICB479, ICB525, ICB532, ICB569, ICB528, ICB115, ICB22, ICB567, ICB561 e ICB565; e de Klebsiella sp. - 
ICB439 e ICB553. O segundo é formado pelas linhagens: de Enterobacter sp. ICB522, ICB573, ICB101, ICB105, ICB118, ICB551, ICB464, ICB405 e ICB481; de Klebsiella sp. - ICB365, ICB369, ICB375 e ICB572; e de Grimontella sp. - ICB397. Erwinia sp., ICB409, mostrou-se filogeneticamente próxima às enterobactérias pela análise do gene 16S rRNA. As três linhagens de Herbaspirillum sp. ficaram agrupadas, bem como as duas de Pseudomonas sp., Chryseobacterium sp., Acinetobacter sp., Rhizobium sp. e Gluconacetobacter sp. mostraram-se distintas das demais.

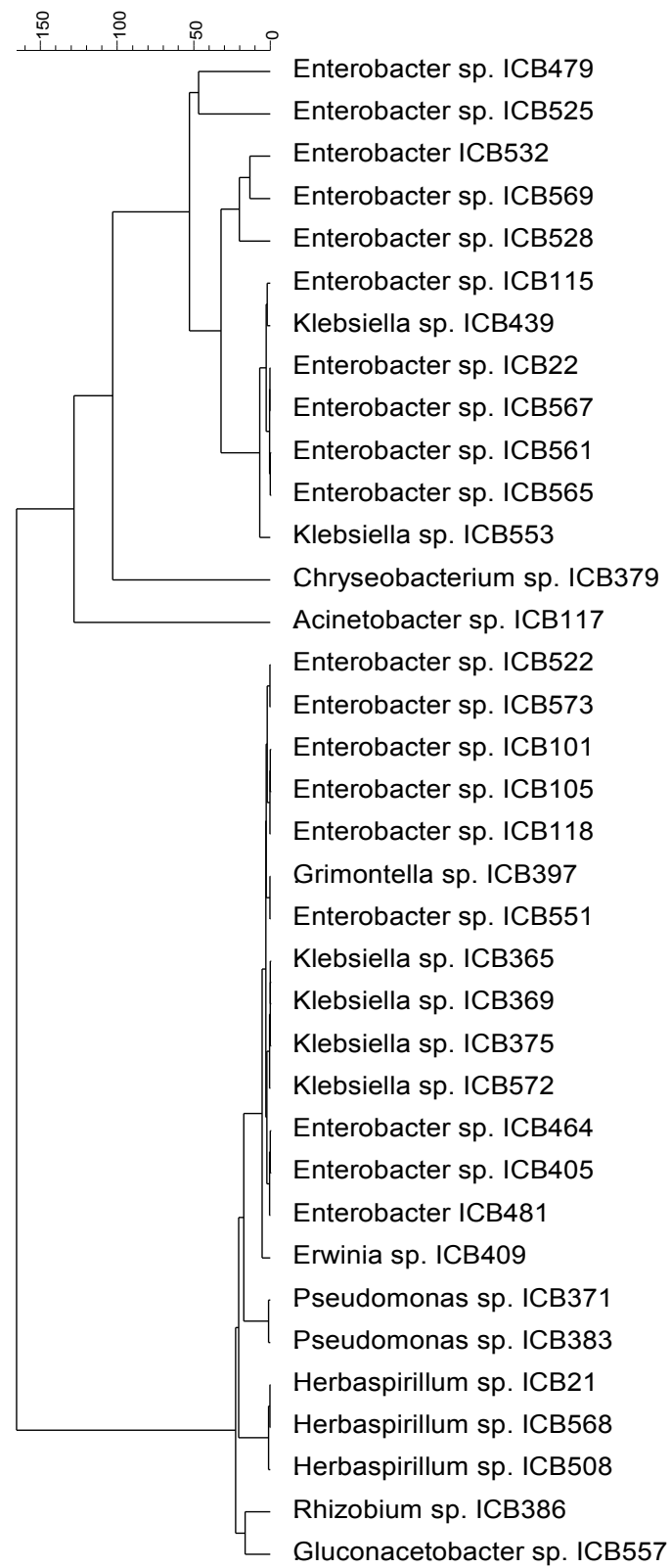


Figura 5 - Árvore filogenética construída a partir da amplificação do gene 16S rRNA (1300pb) de 36 linhagens bacterianas endofíticas isoladas de cana-de-açúcar. Para a geração da matriz de similaridade e construção da árvore filogenética foram utilizados o método de UPGMA e fator de correção de Jukes e Cantor.

As árvores filogenéticas concatenadas obtidas a partir do sequenciamento dos

genes recA, gapA e 16S rRNA construidas pelos métodos da Máxima Parcimonia

(Figura 6) e de Neighbour-Joining (Figura 7) apresentaram a mesma topologia. As

Linhagens ICB493, ICB494 e ICB506 apresentaram alta similaridade com as linhagens

tipo de R. Etli, R.hainanense e R. Tropici, respectivamente. As linhagens ICB456,

ICB500, ICB503 e ICB504, mostraram-se próximas filogeneticamente umas às outras, entretanto, localizaram-se em um ramo separado das demais.

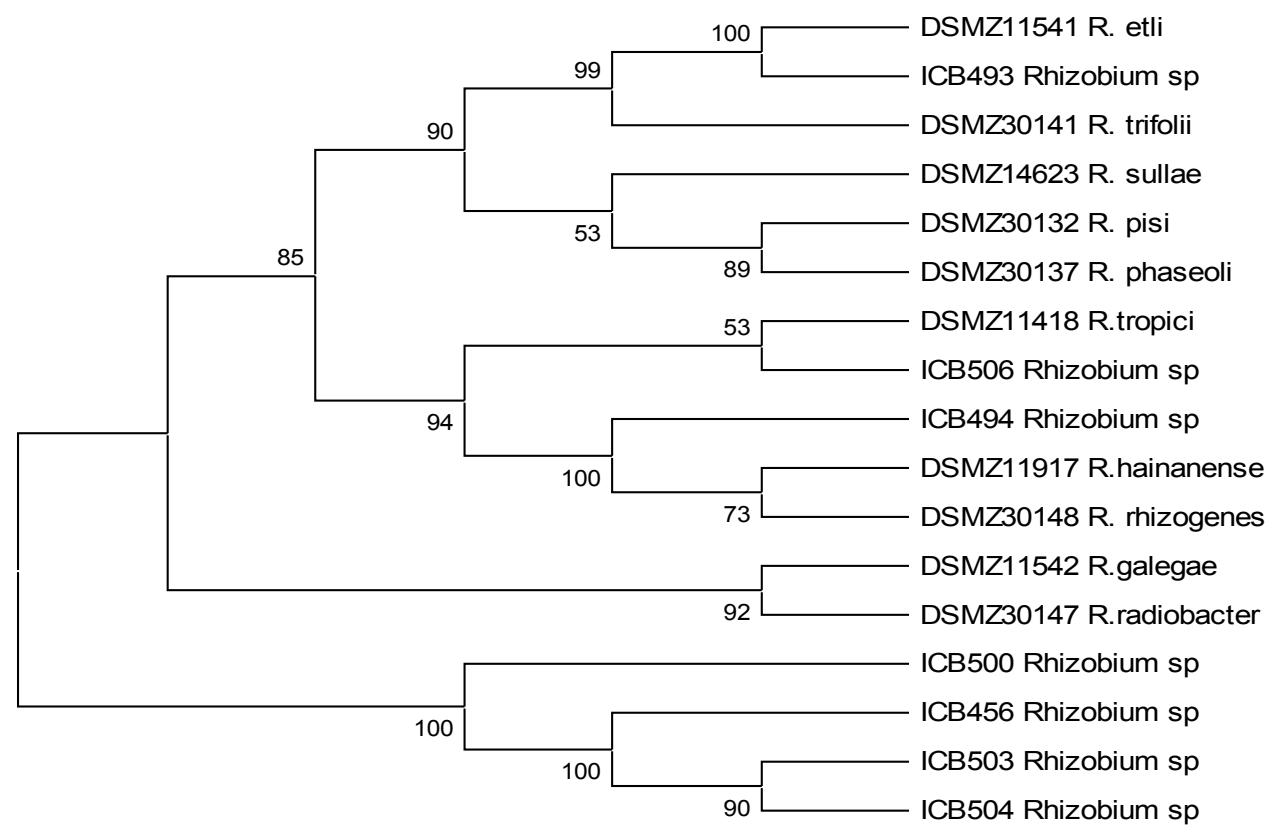

Figura 6 - Árvore filogenética construída a partir da amplificação dos genes concatenados recA (360pb), gapA (480pb) e 16S rRNA (1400pb) de sete linhagens bacterianas endofíticas isoladas de cana-de-açúcar pertencentes ao gênero Rhizobium. A matriz de similaridade foi gerada através do programa MEGA ${ }^{\circledR}$. A construção da árvore filogenética foi feita pelo método da Máxima 
Parcimonia.

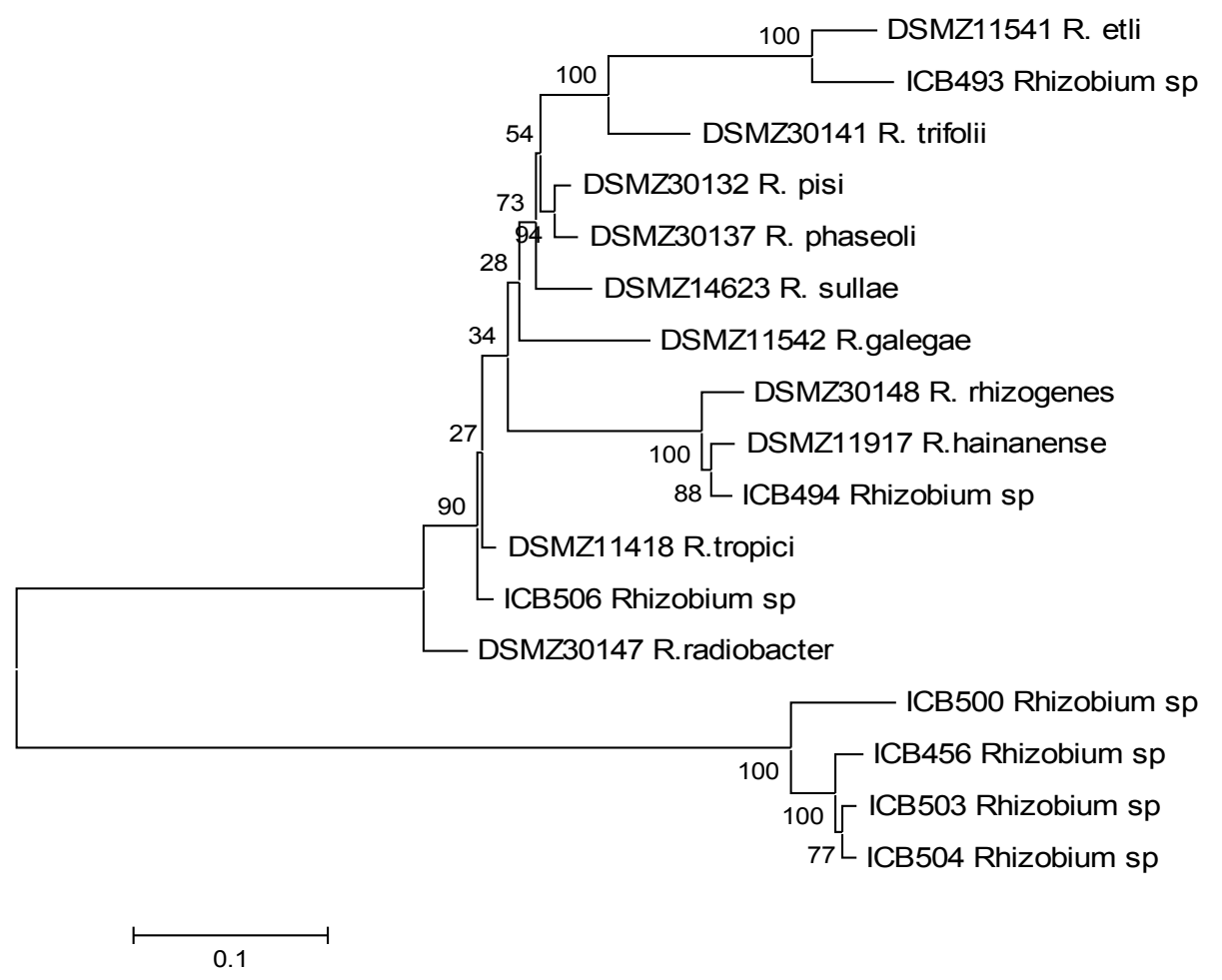

Figura 7 - Árvore filogenética construída a partir da amplificação dos genes concatenados recA (360pb), gapA (480pb) e 16S rRNA (1400pb) de sete linhagens bacterianas endofíticas isoladas de cana-de-açúcar pertencentes ao gênero Rhizobium. A matriz de similaridade foi gerada através do programa $\mathrm{MEGA}^{\circledR}$. Para a construção da árvore filogenética foi utilizado o método de neighbour-joining com fator de correção de Jukes \& Cantor.

\subsection{DOSAGEM DE SUBSTÂNCIAS LIBERADAS POR BEFN}

As 36 bactérias analisadas quanto a liberações de SPCV, evidenciaram resultados bastante distintos. Apesar de linhagens do mesmo gênero apresentarem crescimento, atividade específica e excreção de SPCV, com diferenças entre si, algumas semelhanças puderam ser observadas. Todas estas características serão 
usadas como base do presente trabalho. Foram comuns a todos os isolados a ausência de uma fase de lag, a duração da fase exponencial (24h), cujo valor máximo se limitou entre $10^{6}$ e $10^{8}$ UFC. $\mathrm{ml}^{-1}$. O pico de atividade da nitrogenase foi detectado geralmente nas primeiras cinco horas do experimento. Dentre as bactérias que produziram poliaminas, a liberação de putrescina foi comum a todas.

Para efeito de comparação, os resultados serão, em princípio, mostrados individualmente, por gênero bacteriano. Em seguida, serão descritos os resultados referentes à interferência do tipo de adubação na diversidade fisiológica dos isolados.

\section{a) Herbaspirillum}

As curvas de crescimento de Herbaspirillum sp. ICB21, ICB508 e ICB568 (Figuras 8, 9 e 10) mostram que o maior valor populacional de ICB508 foi de $1,5.10^{8}$ UFC.mll ${ }^{-1}$, enquanto que os mesmos valores de ICB21 e ICB568 foram próximos de $5,0.10^{7}$ UFC. $\mathrm{ml}^{-1}$. As três culturas mantiveram-se viáveis durante todo o período do experimento e ao final de $200 \mathrm{~h}$ suas populações apresentavam em torno de $2,0.10^{7}$ células.

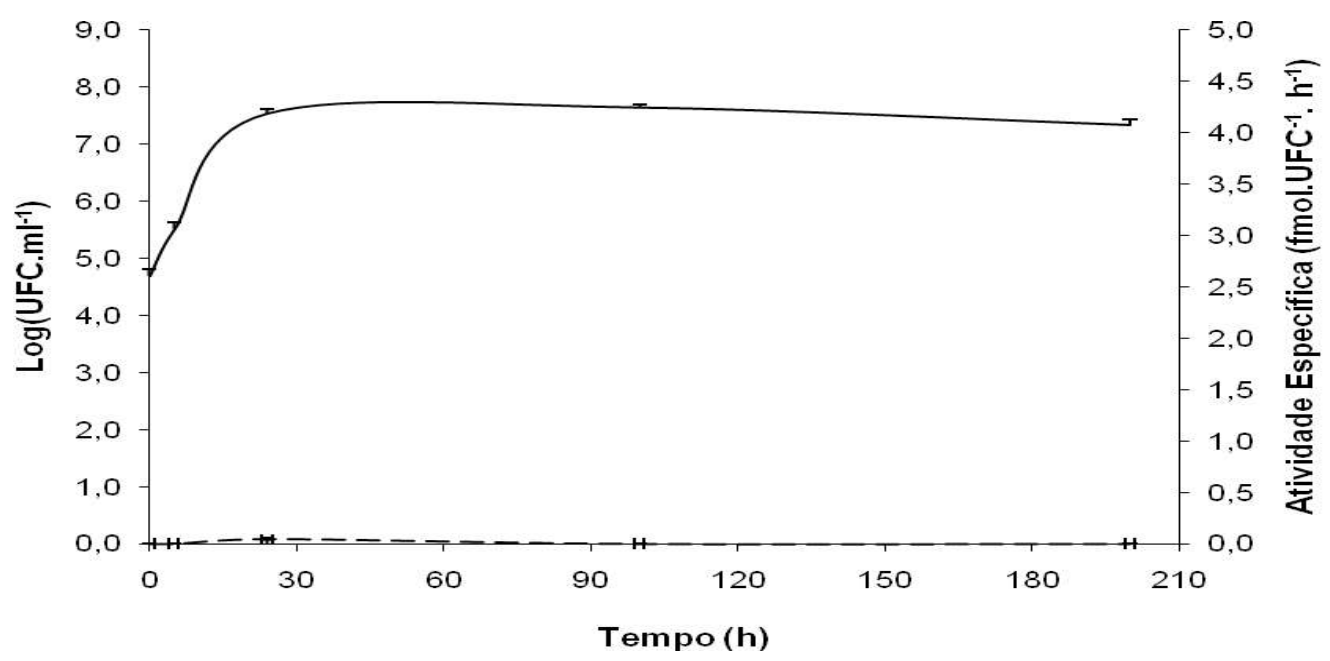


Figura 8 - Crescimento medido pelo Log (UFC) (-) e atividade específica (- - -) da enzima nitrogenase de Herbaspirillum sp. (ICB21) em função do tempo em meio MMS.

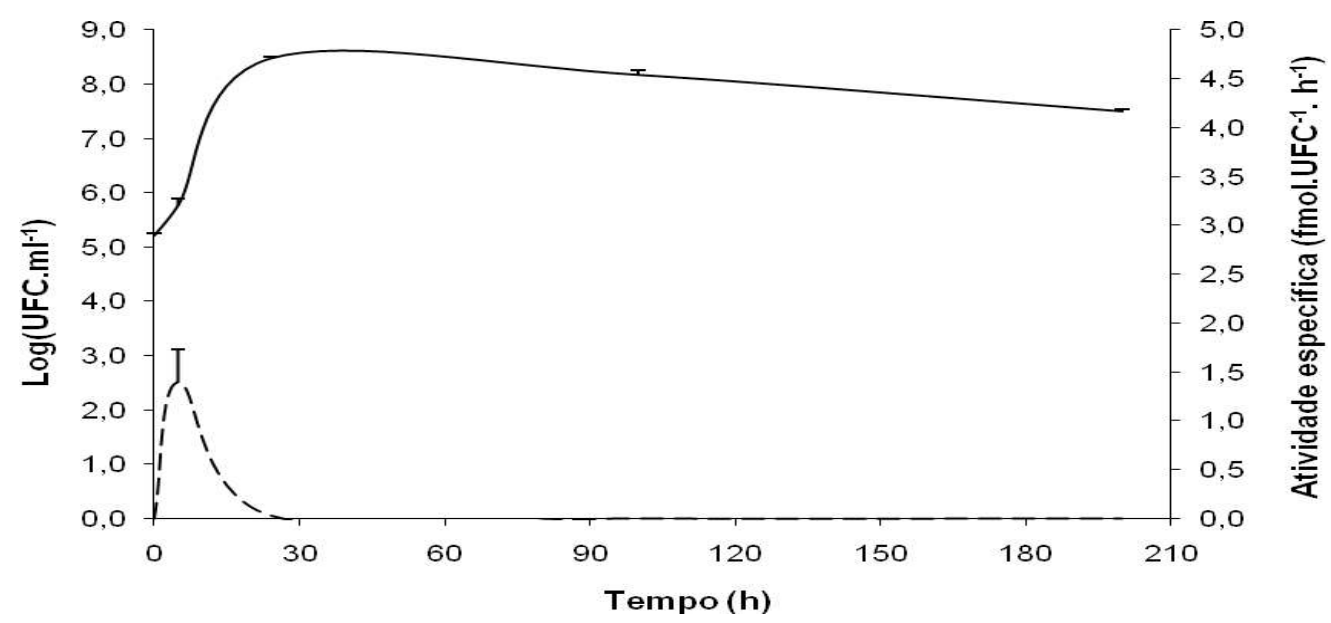

Figura 9 - Crescimento medido pelo Log (UFC) (-) e atividade específica (- - -) da enzima nitrogenase de Herbaspirillum sp. (ICB508) em função do tempo em meio MMS.

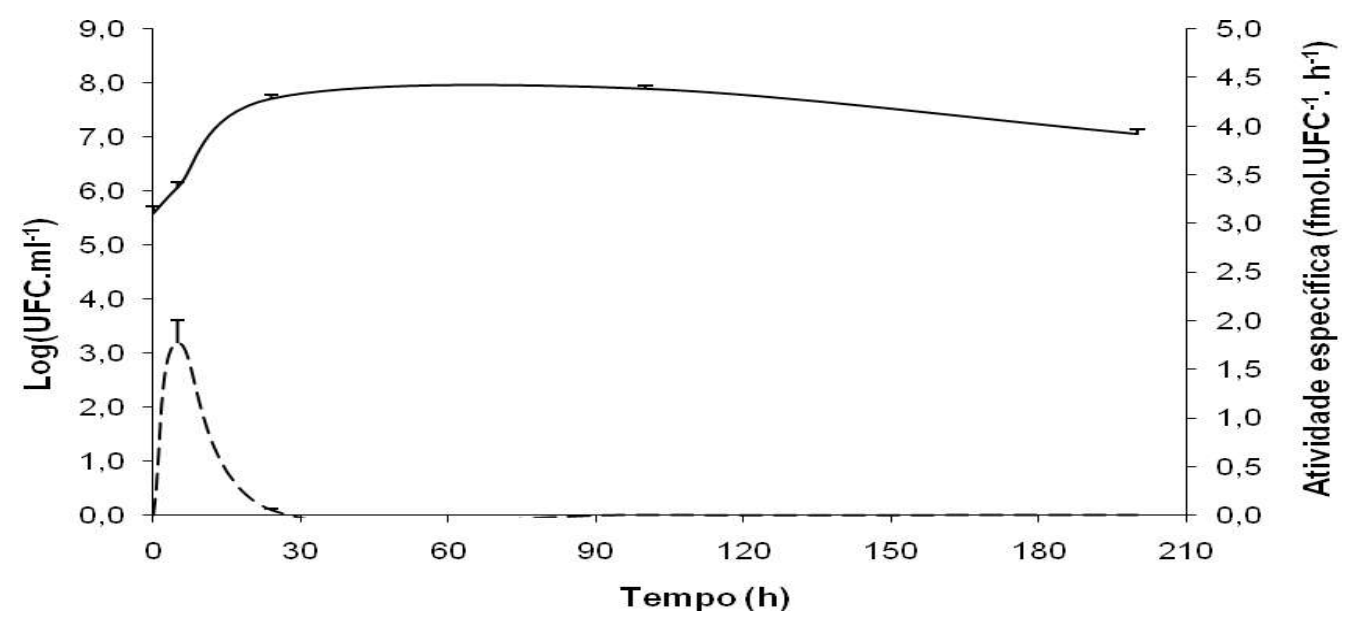

Figura 10 - Crescimento medido pelo Log (UFC) (-) e atividade específica (- - -) da enzima nitrogenase de Herbaspirillum sp. (ICB568) em função do tempo em meio MMS.

Os perfis das curvas de atividade específica da nitrogenase diferiram entre as linhagens da seguinte forma: os isolados ICB508 e ICB568 apresentaram picos de atividade de 1,6 e 1,9 fmol.UFC ${ }^{-1} \cdot \mathrm{h}^{-1}$, respectivamente, após cinco horas de 
crescimento; estes valores foram seguidos por quedas acentuadas nas medidas realizadas após $24 \mathrm{~h}$ de cultivo (Figuras 9 e 10). ICB21 reduziu apenas 0,04 fmol.UFC${ }^{1} \cdot \mathrm{h}^{-1}$ de acetileno após 24h (Figura 8).

Dessas três linhagens, ICB21 e ICB508 liberaram aminoácidos em cultura pura (Figuras 11 e 12). Houve diferença nas quantidades e variedades de aminoácidos liberados. ICB21 excretou, após 200h, 10 aminoácidos diferentes (Asp, Glu, Ser, Ala, Tyr, Val, Phe, Ile, Leu e Orn). As maiores concentrações detectadas foram de Asp e Ser, que atingiram $0,14 \mu \mathrm{g} \cdot \mathrm{ml}^{-1} \mathrm{e}$ o total de aminoácidos atingiu $0,56 \mu \mathrm{g} \cdot \mathrm{ml}^{-1}$.

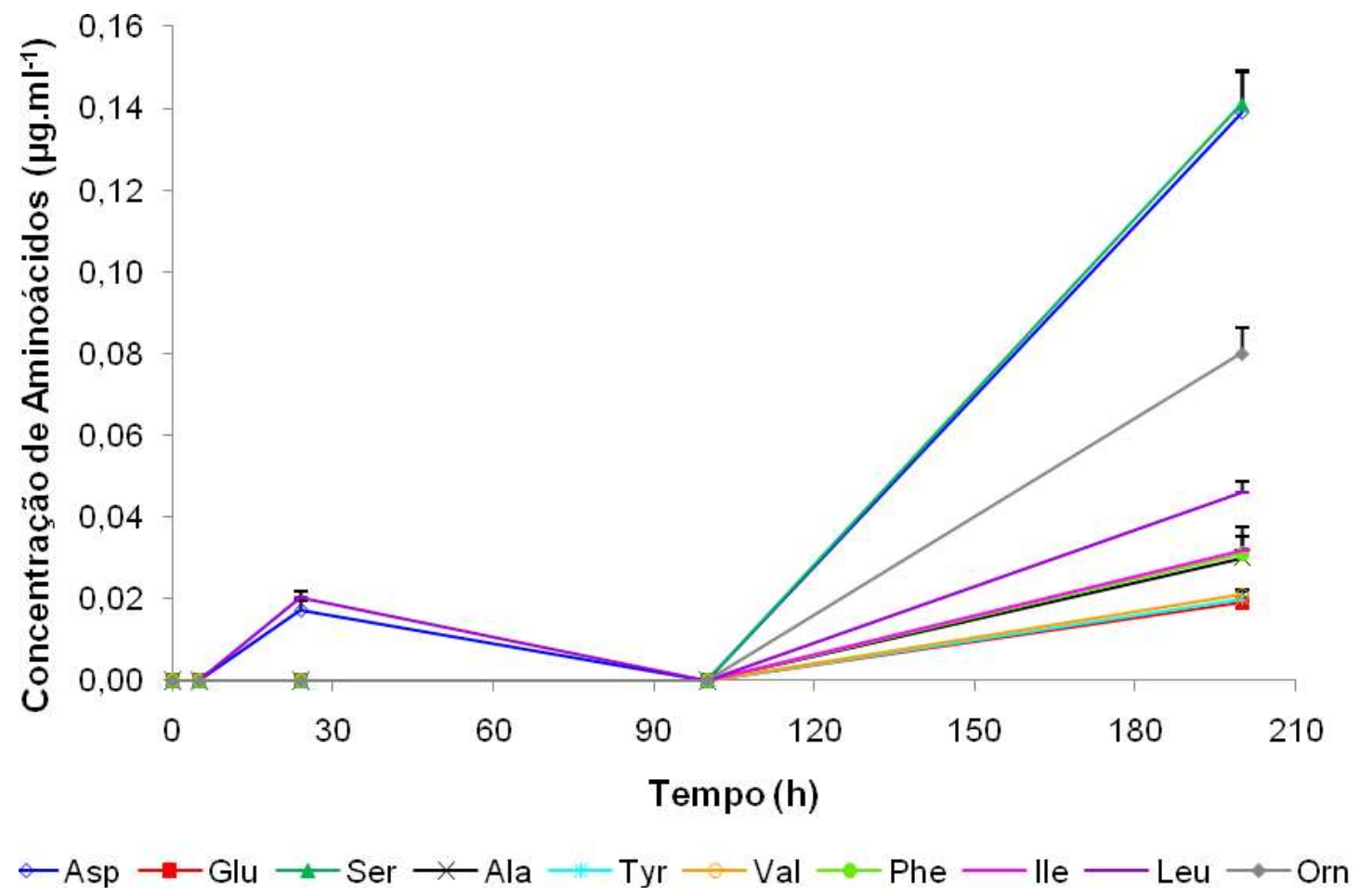

Figura 11 - Concentração de aminoácidos livres no meio ao longo do tempo em culturas de Herbaspirillum sp. (ICB21) em meio MMS.

ICB508 liberou aminoácidos em quantidades bem maiores que ICB21, porém em menor variedade (Asp, Glu, Ser, Phe, lle, Gly e Orn). A quantidade total de aminoácidos acumulados no meio chegou a $3,51 \mu \mathrm{g} \cdot \mathrm{ml}^{-1} \mathrm{em} 200 \mathrm{~h}$. Os mais abundantes foram: Asp, 
Glu e Ser com 0,95, 0,66 e 0,62 $\mu \mathrm{g} \cdot \mathrm{ml}^{-1}$, respectivamente.

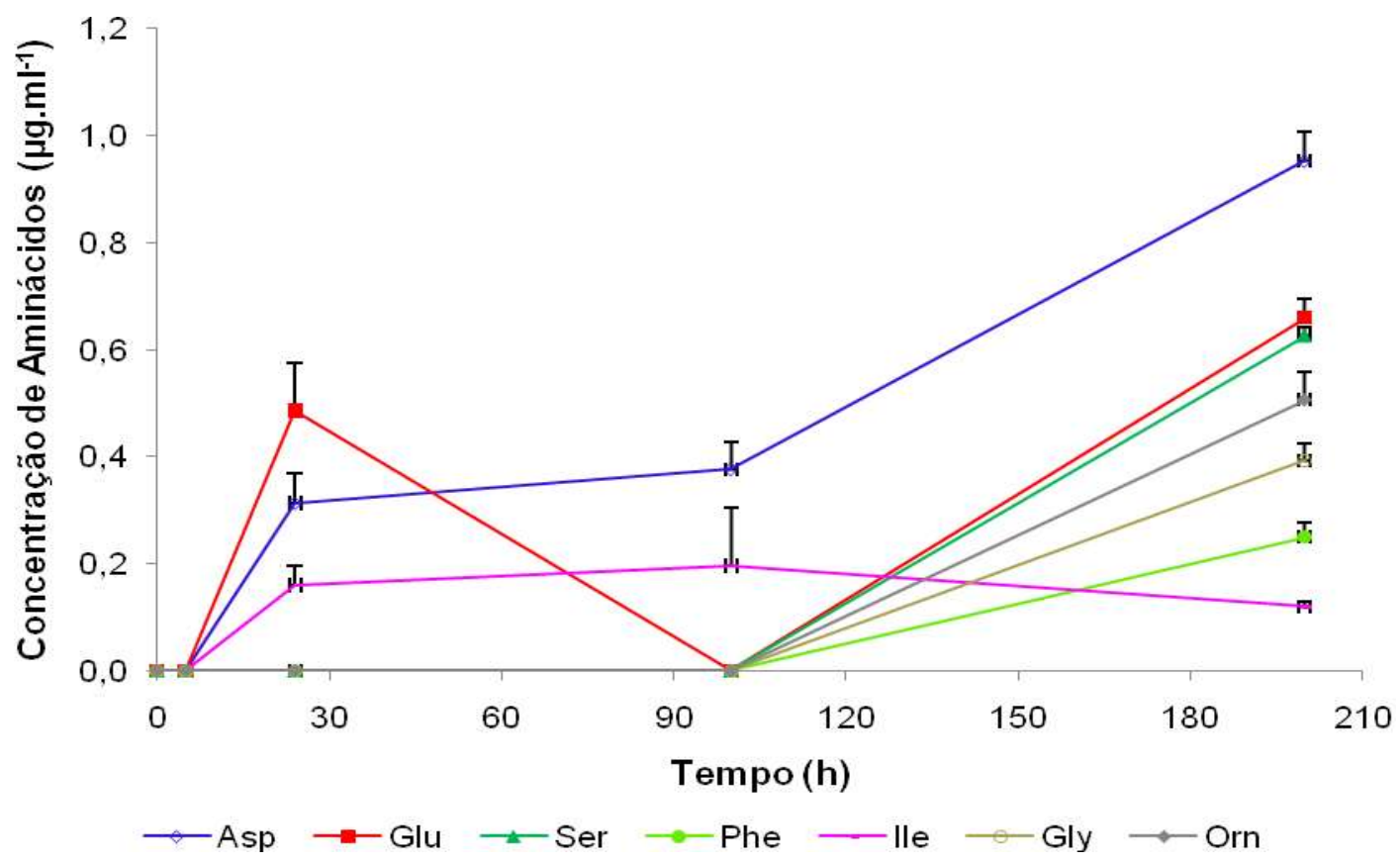

Figura 12 - Concentração de aminoácidos livres no meio ao longo do tempo em culturas de Herbaspirillum sp. (ICB508) em meio MMS.

As três linhagens: ICB21, ICB508 e ICB568 liberaram AIA cujas-concentrações variaram de acordo com o tempo e a cultura estudada (Figura 13).

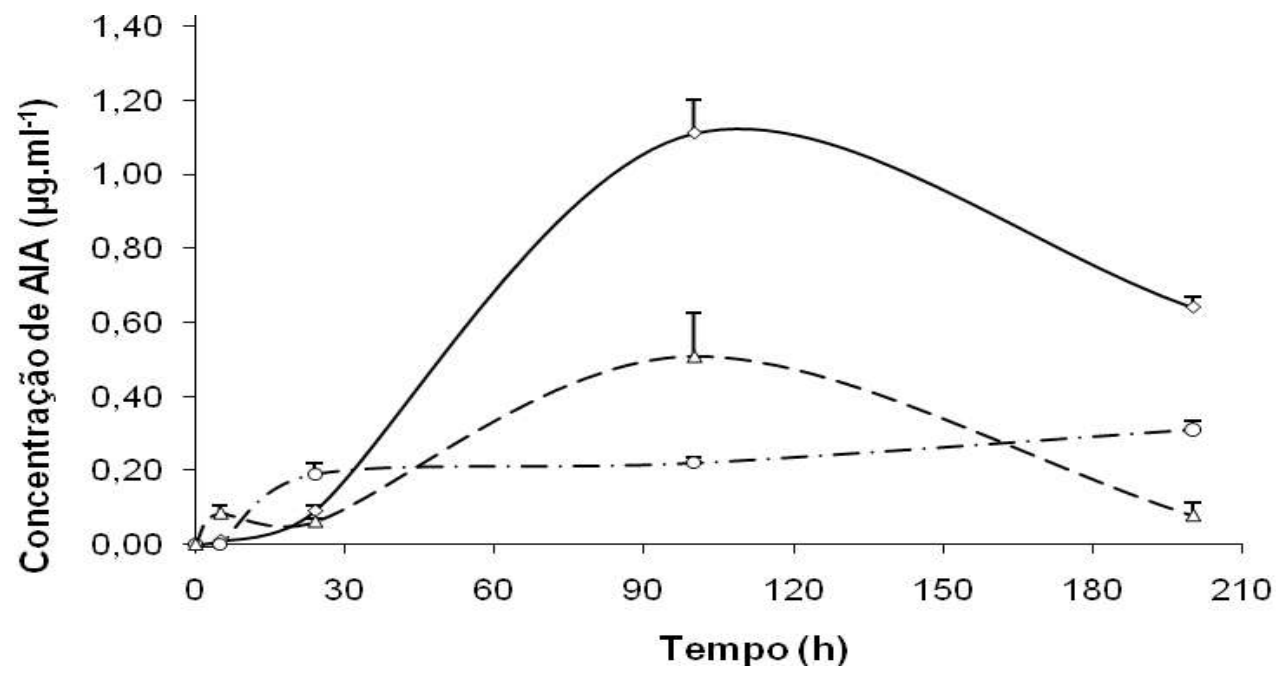


Figura 13 - Concentração de AIA livre detectada em meio MMS em função do tempo em culturas de Herbaspirillum sp.: ICB21(-); ICB508 ( - ); e ICB56 (- - -)

As concentrações máximas de AIA produzidas por ICB21, ICB508 e ICB568 foram, respectivamente, 1,11, 0,31 e $0,51 \mu \mathrm{g} \cdot \mathrm{ml}^{-1}$ (Figura 13), sendo que nos meios de ICB21 e ICB568 aumentaram até 100h e diminuíram com 200h. Na cultura de ICB508 houve aumento acentuado nas primeiras $24 \mathrm{~h}$ seguido por um pequeno acúmulo até o final do experimento.

A única linhagem de Herbaspirillum sp. capaz de liberar etileno foi ICB568. Foram detectadas concentrações de 2,88 $\pm 0,15 \eta \mathrm{mol}^{\mathrm{ml}}{ }^{-1}$ do hormônio após $144 \mathrm{~h}$ de crescimento com estabilização $\left(2,53 \pm 0,02 \eta \mathrm{mol}^{\mathrm{ml}} \mathrm{l}^{-1}\right)$ até o final do experimento, com 240h.

\section{b) Enterobacter}

O gênero com maior número de linhagens estudadas foi Enterobacter. As curvas de crescimento e de atividade específica das diferentes linhagens apresentaram algumas variações (Figuras 14 a 30). Em geral, os números iniciais de células foram próximos a $10^{5} \mathrm{UFC} \cdot \mathrm{ml}^{-1}$. A fase exponencial foi detectada em até $24 \mathrm{~h}$ e maioria dos isolados atingiu a fase estacionária com populações superiores a $1.10^{7}$ UFC. $\mathrm{ml}^{-1}$. O maior crescimento foi detectado em ICB528 com 6,25.107 UFC.ml-1 (Figura 24). Três linhagens atingiram valores mais baixos de população, entre $1,0.10^{6}$ e $3,0.10^{6}$ (Figuras 18, 19 e 20). Seis bactérias apresentaram uma fase estacionária típica (Figuras 21, 22, 23, 27, 28 e 29) e onze apresentaram declínio nas contagens de UFC 
após 200h (Figuras 14, 15, 16, 17, 18, 19, 23, 24, 25, 26 e 30).

A atividade específica da nitrogenase variou de 2,4 até $297,75 \mathrm{fmol} . \mathrm{UFC}^{-1} \cdot \mathrm{h}^{-1}$ dependendo da linhagem. As taxas de redução de acetileno foram: menores que 25 fmol.UFC ${ }^{-1} \cdot h^{-1}$, em sete isolados (Figuras 18, 19, 20, 24, 26, 27 e 28); entre 25 e 100 fmol.UFC ${ }^{-1} \cdot h^{-1}$, em cinco isolados (Figsuras 14, 21, 23, 25 e 29); entre 100 e 200 fmol.UFC ${ }^{-1} \cdot h^{-1}$, em três isolados (Figuras 15, 22 e 30) e entre 200 e 300 (Figuras 16 e 17) fmol.UFC ${ }^{-1} \cdot \mathrm{h}^{-1} \mathrm{em}$ dois isolados. A maioria das bactérias (59\%) ficou ativa por $100 \mathrm{~h}$, com valores bem mais baixos que os detectados nos picos. ICB101, ICB481, ICB567 e ICB569 apresentaram atividade de nitrogenase apenas durante cinco horas e ICB118, ICB551 e ICB573 permaneceram ativas até, pelo menos, 24h.

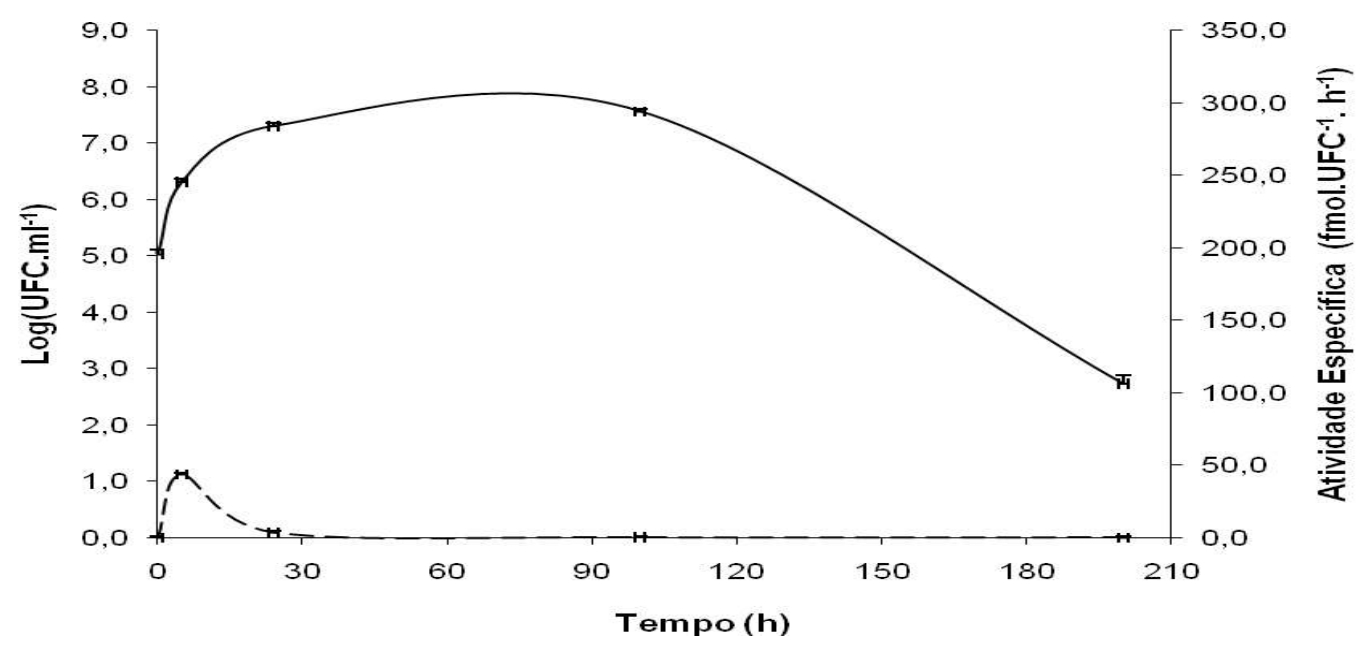

Figura 14 - Crescimento medido pelo Log (UFC) (-) e atividade específica (- - -) da enzima nitrogenase de Enterobacter sp. (ICB22) em função do tempo em meio MMS. 


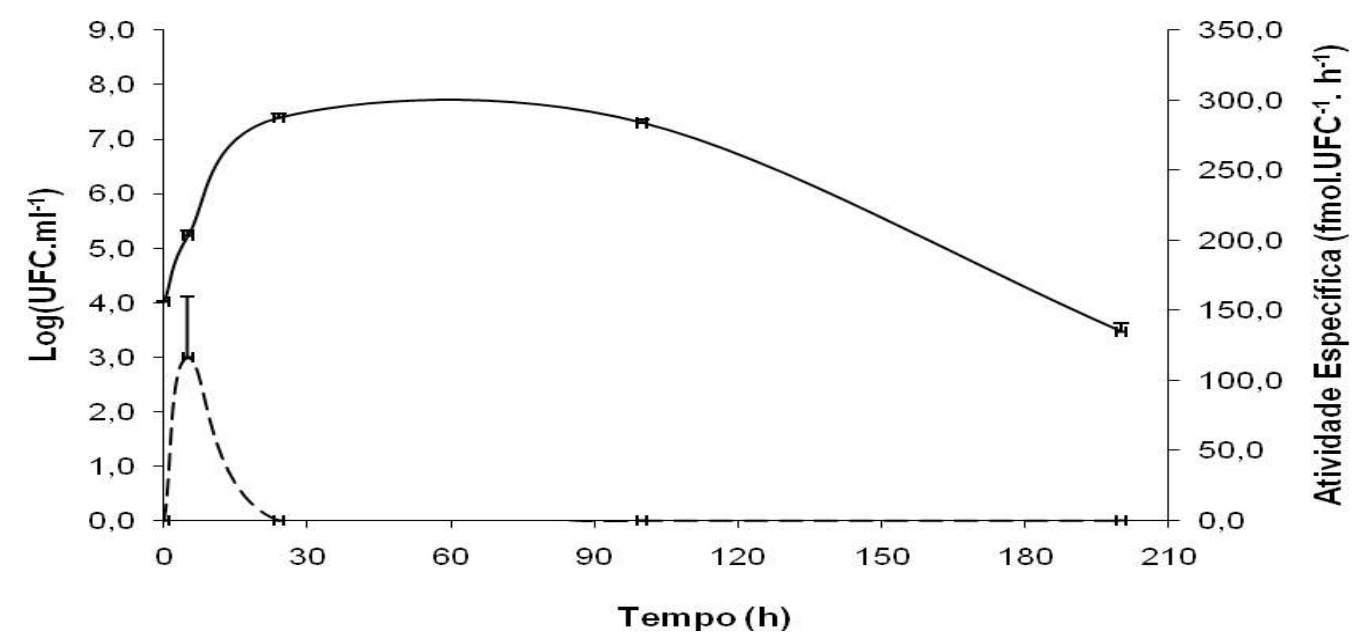

Figura 15 - Crescimento medido pelo Log (UFC) (-) e atividade específica (- - -) da enzima nitrogenase de Enterobacter sp. (ICB101) em função do tempo em meio MMS.

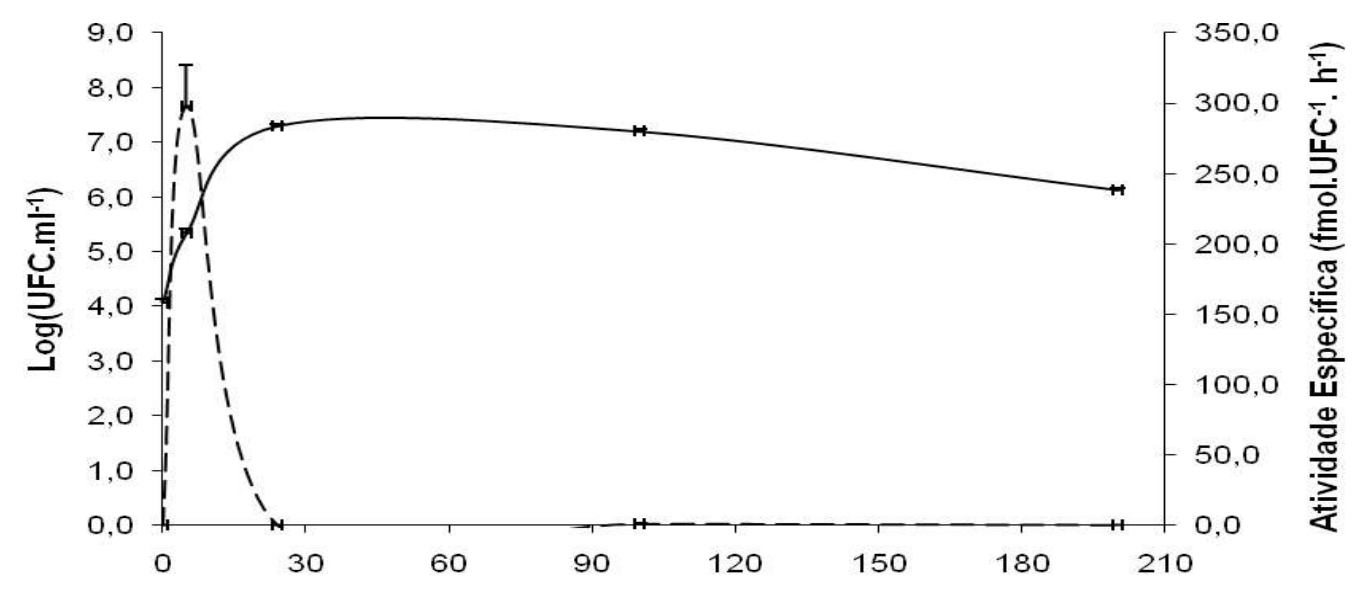

Tempo (h)

Figura 16 - Crescimento medido pelo Log (UFC) (-) e atividade específica (- - -) da enzima nitrogenase de Enterobacter sp. (ICB105) em função do tempo em meio MMS.

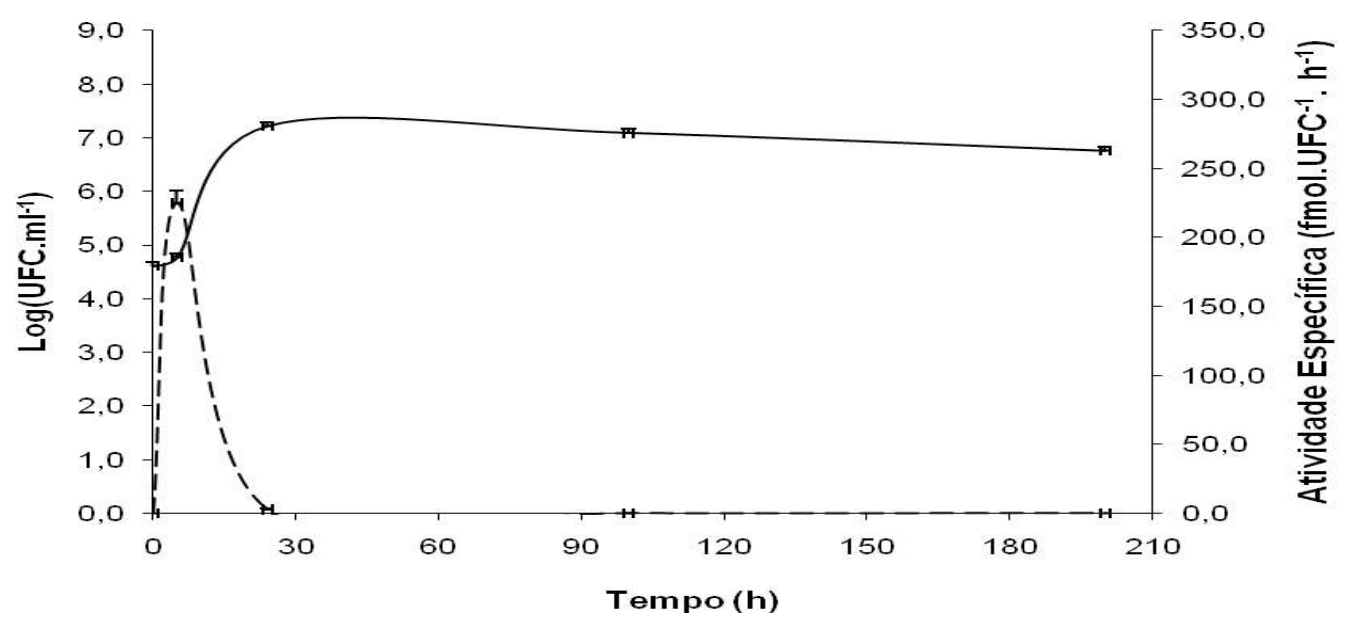


Figura 17 - Crescimento medido pelo Log (UFC) (-) e atividade específica (- - -) da enzima nitrogenase de Enterobacter sp. (ICB118) em função do tempo em meio MMS.

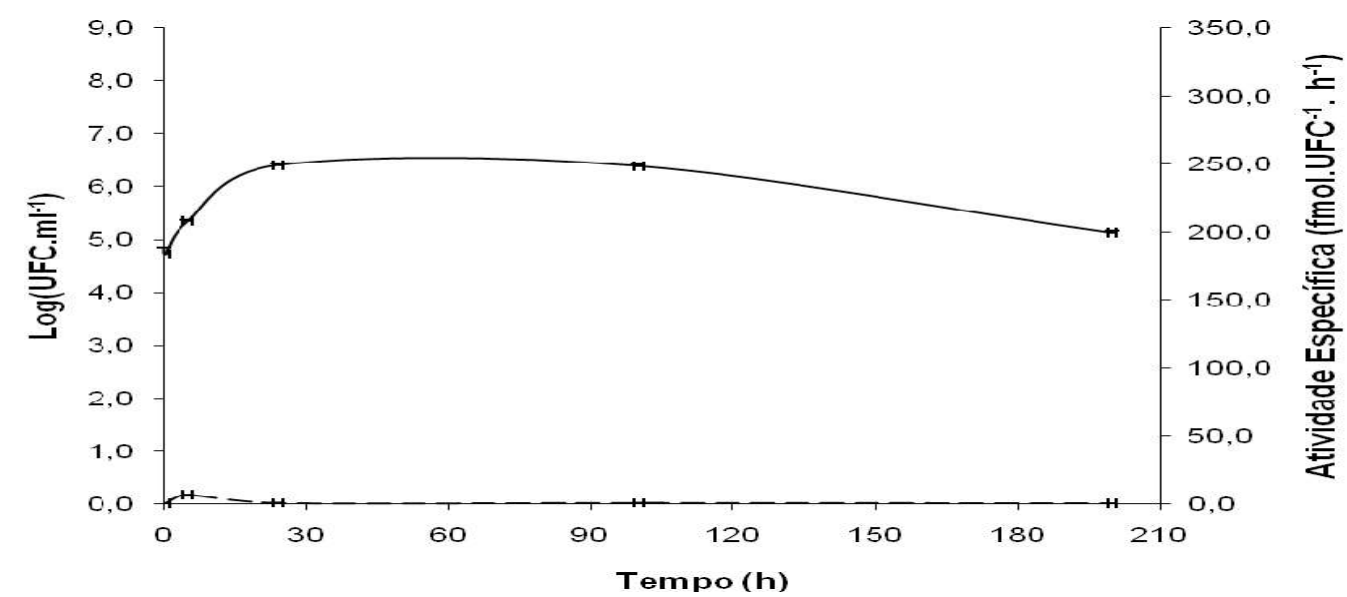

Figura 18 - Crescimento medido pelo Log (UFC) (-) e atividade específica (- - -) da enzima nitrogenase de Enterobacter sp. (ICB405) em função do tempo em meio MMS.

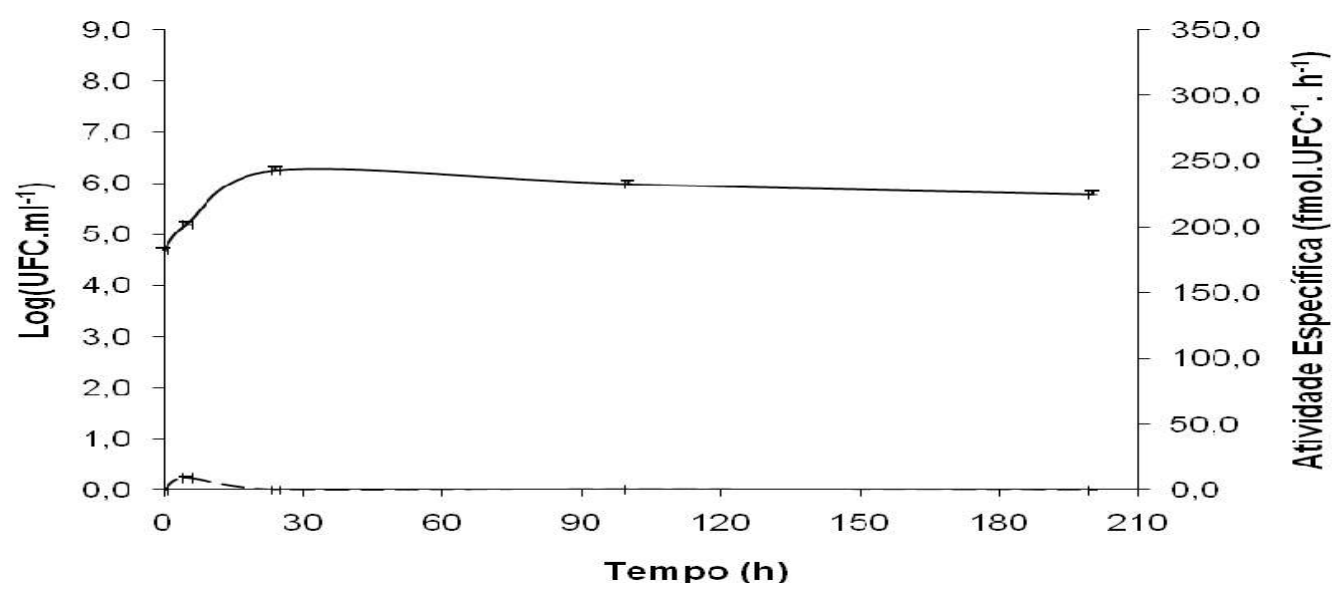

Figura 19 - Crescimento medido pelo Log (UFC) (-) e atividade específica (- - -) da enzima nitrogenase de Enterobacter sp. (ICB464) em função do tempo em meio MMS.

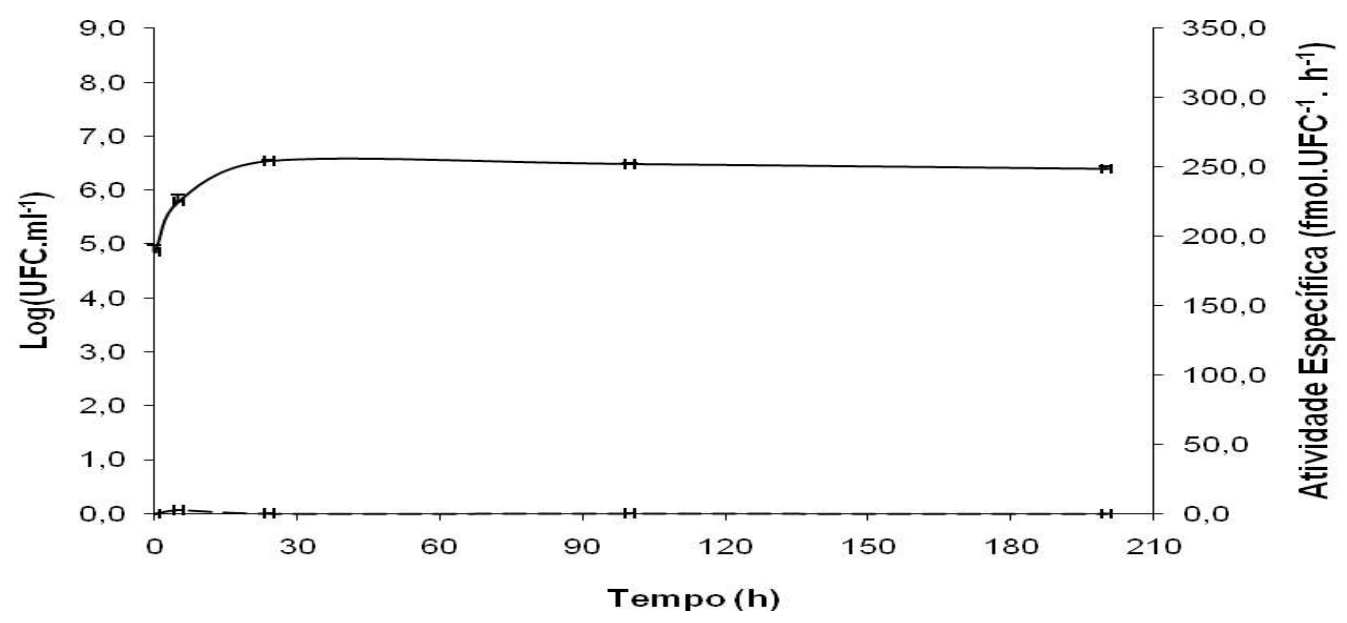


Figura 20 - Crescimento medido pelo Log (UFC) (-) e atividade específica (- - -) da enzima nitrogenase de Enterobacter sp. (ICB479) em função do tempo em meio MMS.

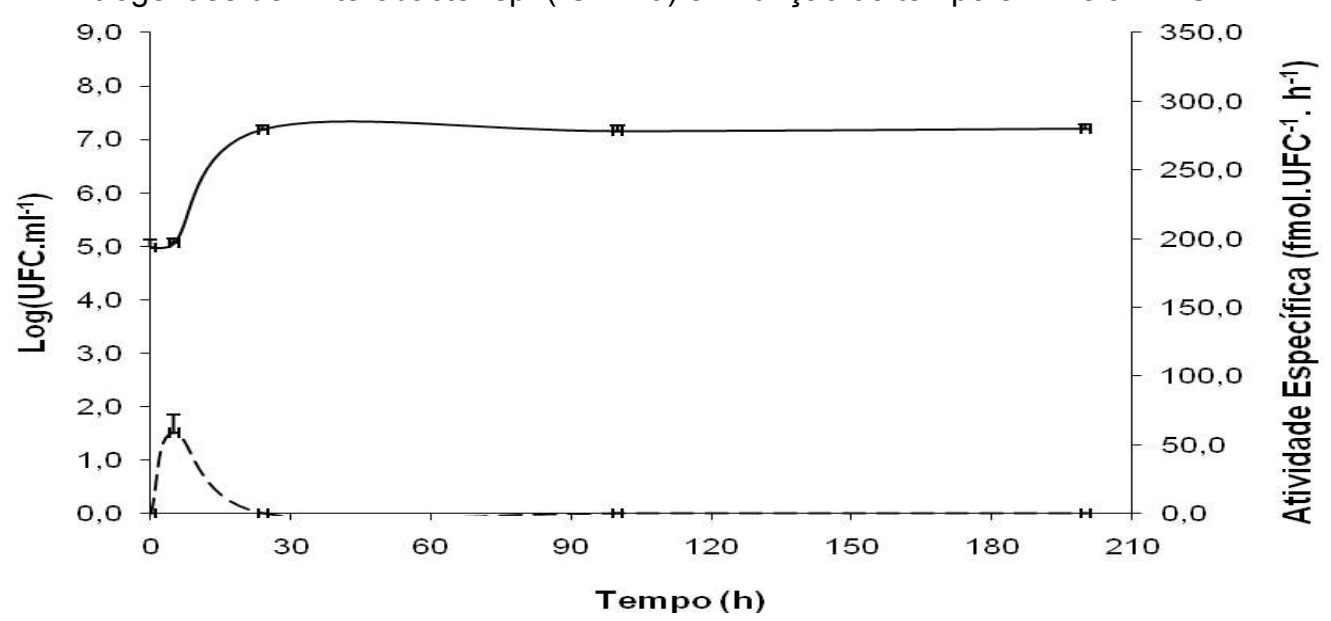

Figura 21 - Crescimento medido pelo Log (UFC) (-) e atividade específica (- - -) da enzima nitrogenase de Enterobacter sp. (ICB481) em função do tempo em meio MMS.

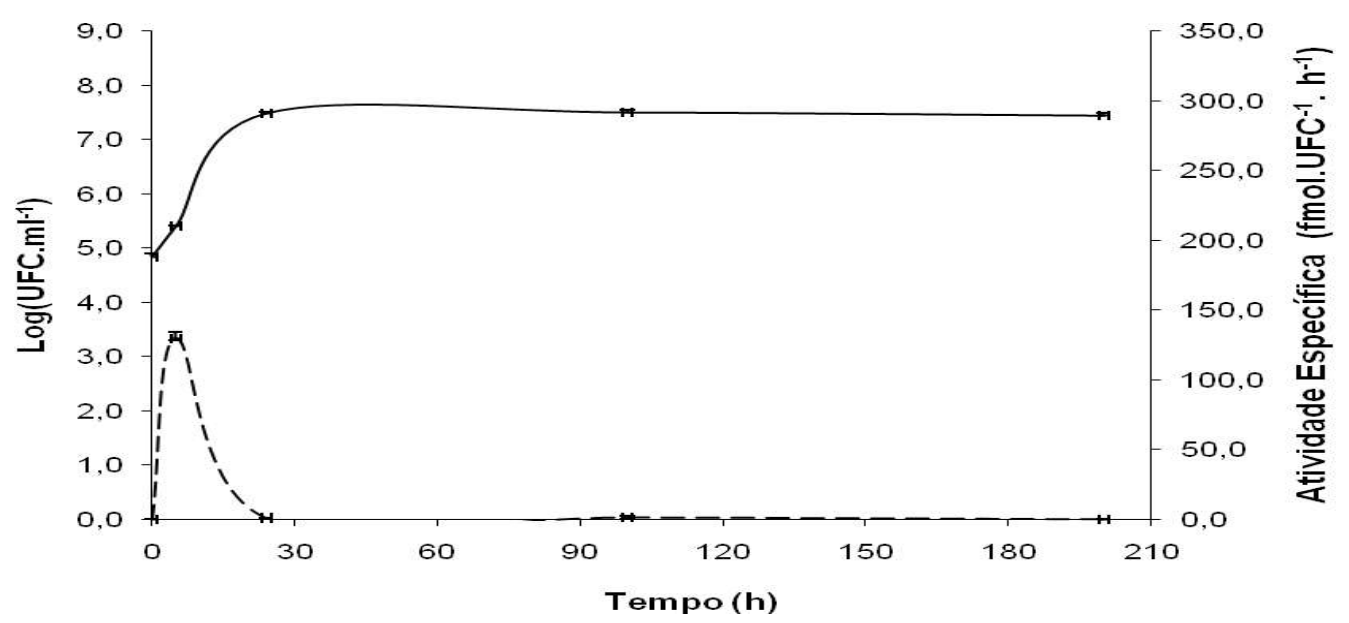

Figura 22 - Crescimento medido pelo Log (UFC) (-) e atividade específica (- - -) da enzima nitrogenase de Enterobacter sp. (ICB522) em função do tempo em meio MMS.

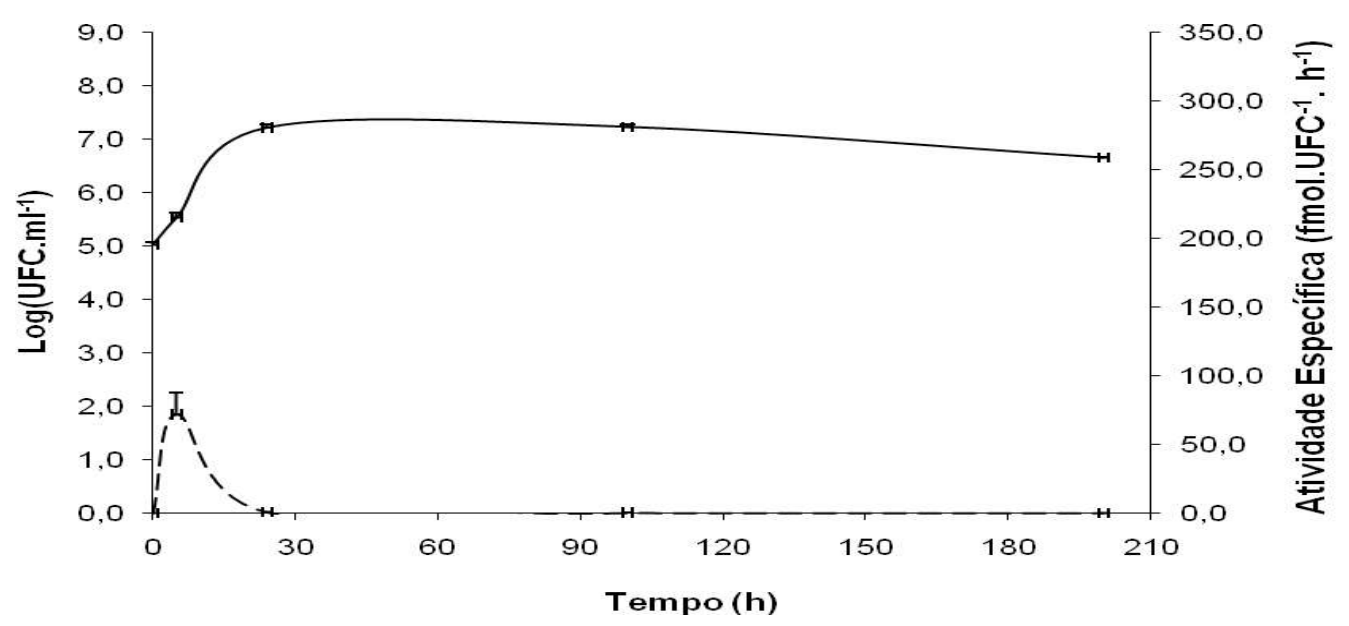


Figura 23 - Crescimento medido pelo Log (UFC) (-) e atividade específica (- - -) da enzima nitrogenase de Enterobacter sp. (ICB525) em função do tempo em meio MMS.

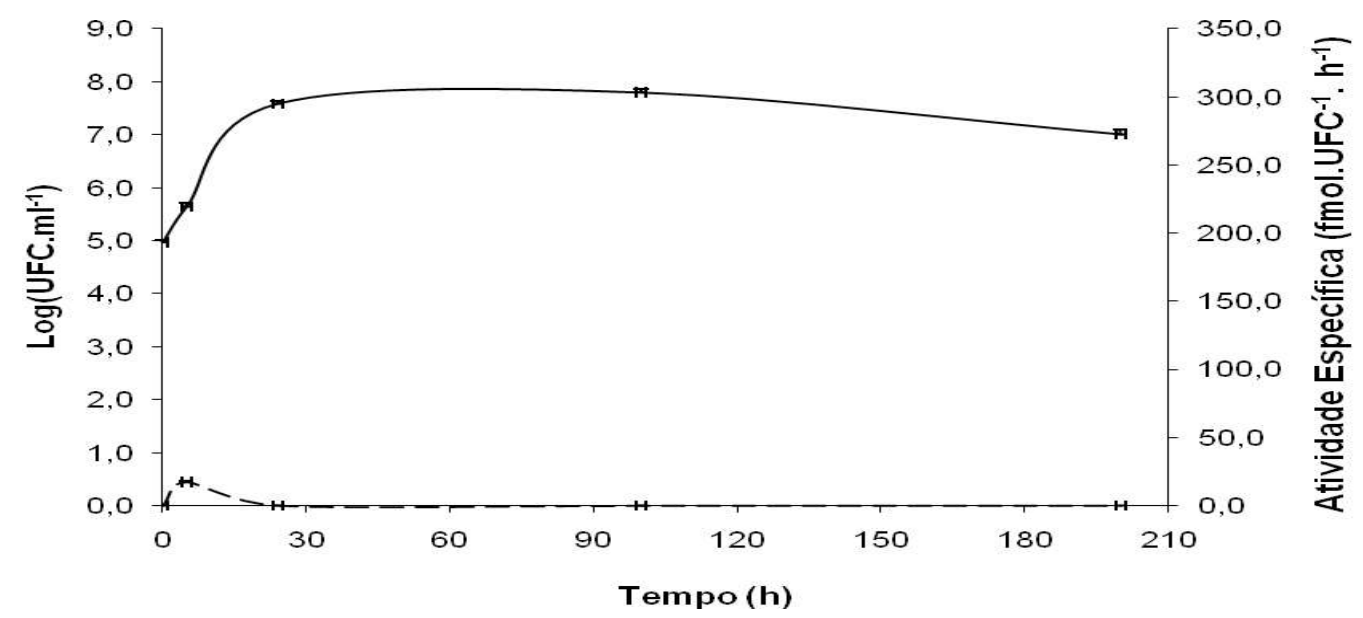

Figura 24 - Crescimento medido pelo Log (UFC) (-) e atividade específica (- - -) da enzima nitrogenase de Enterobacter sp. (ICB528) em função do tempo em meio MMS.

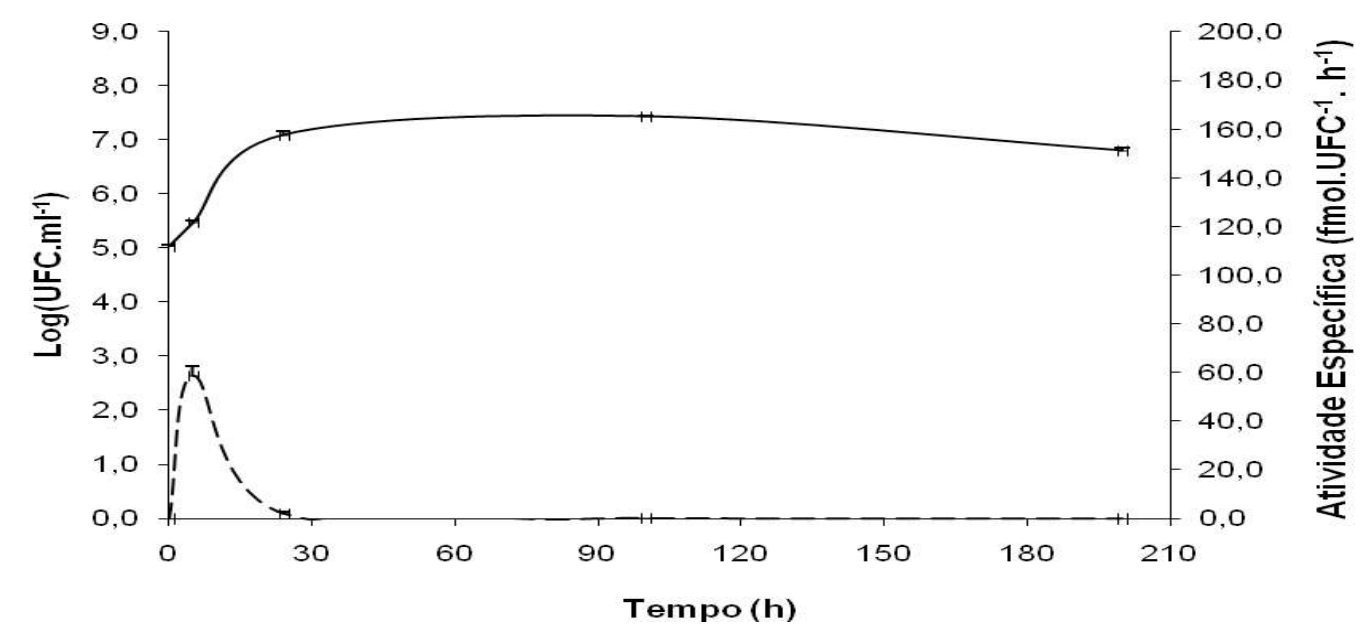

Figura 25 - Crescimento medido pelo Log (UFC) (-) e atividade específica (- - -) da enzima nitrogenase de Enterobacter sp. (ICB532) em função do tempo em meio MMS.

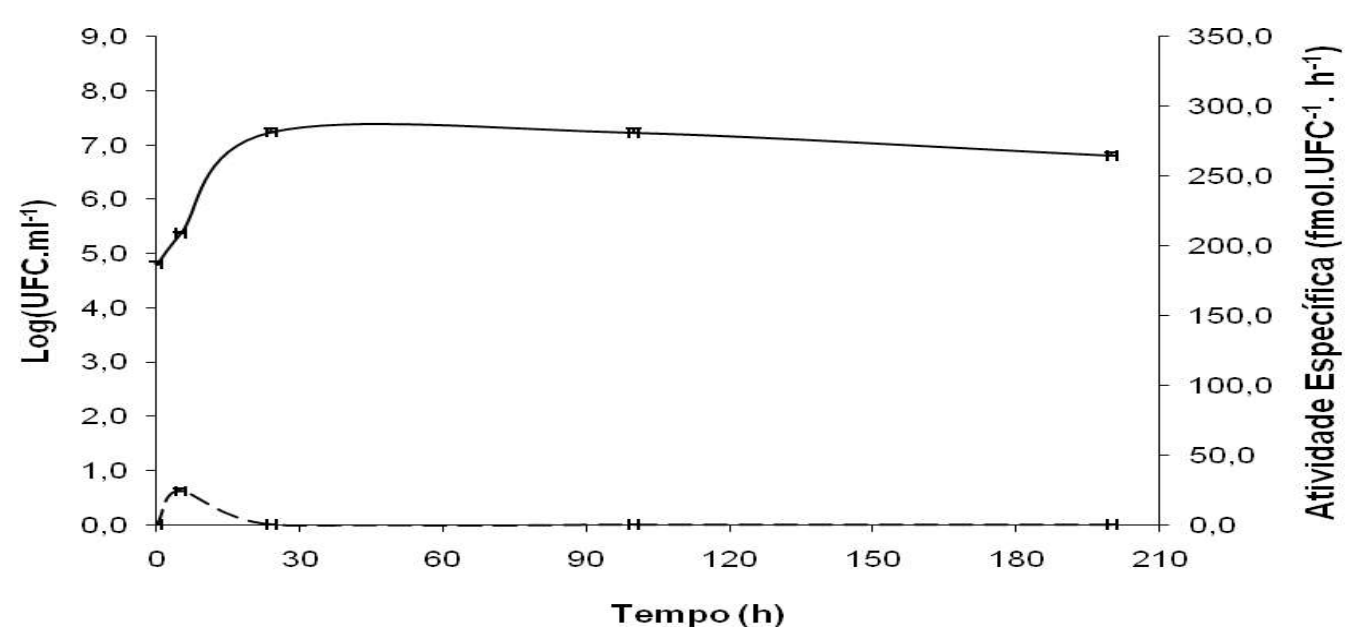


Figura 26 - Crescimento medido pelo Log (UFC) (-) e atividade específica (- - -) da enzima nitrogenase de Enterobacter sp. (ICB551) em função do tempo em meio MMS.

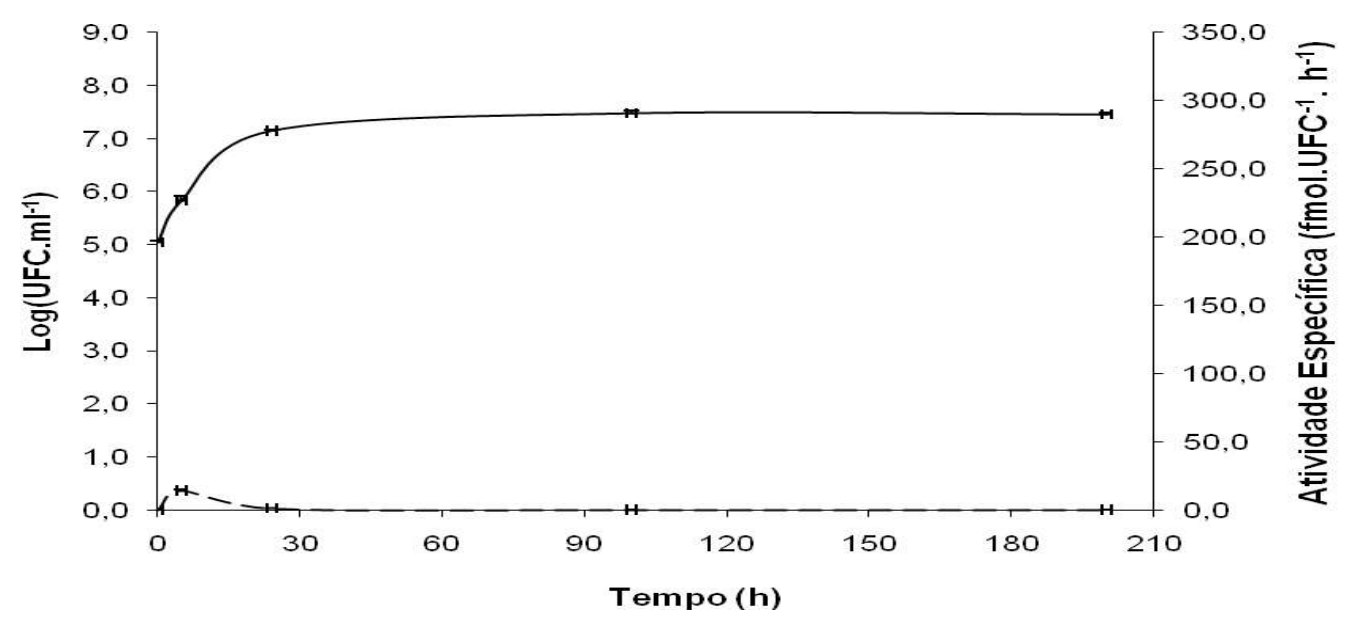

Figura 27 - Crescimento medido pelo Log (UFC) (-) e atividade específica (- - -) da enzima nitrogenase de Enterobacter sp. (ICB561) em função do tempo em meio MMS.

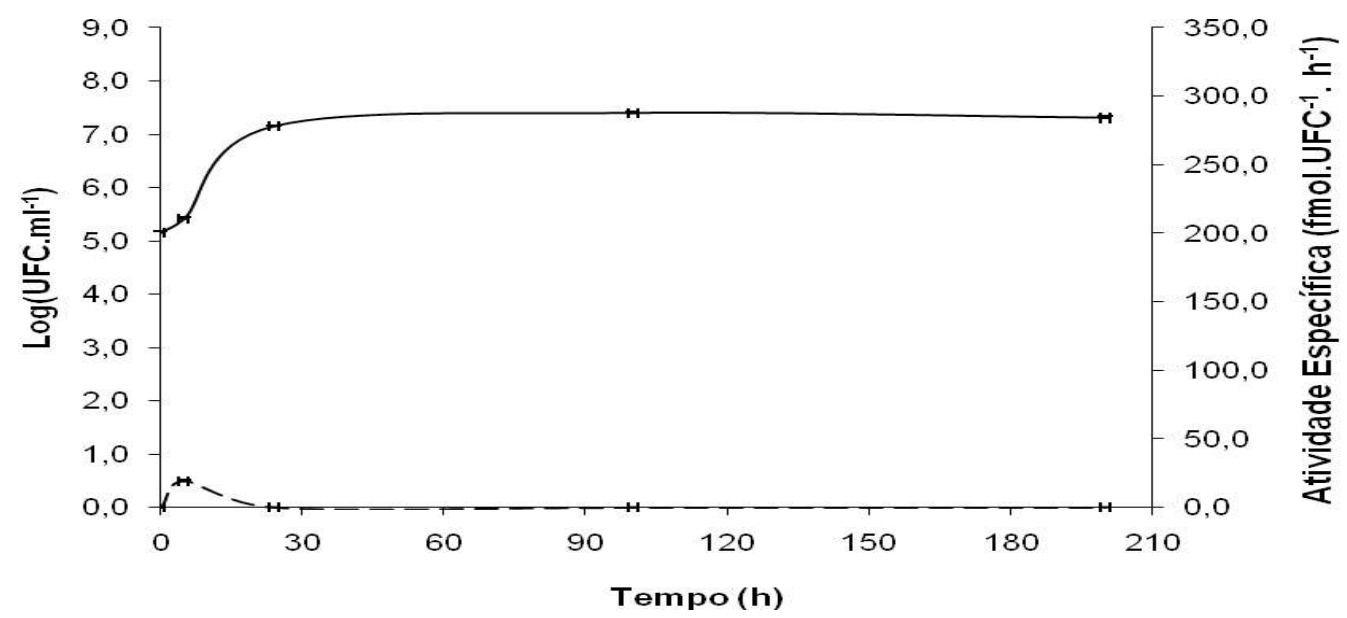

Figura 28 - Crescimento medido pelo Log (UFC) (-) e atividade específica (- - -) da enzima nitrogenase de Enterobacter sp. (ICB567) em função do tempo em meio MMS.

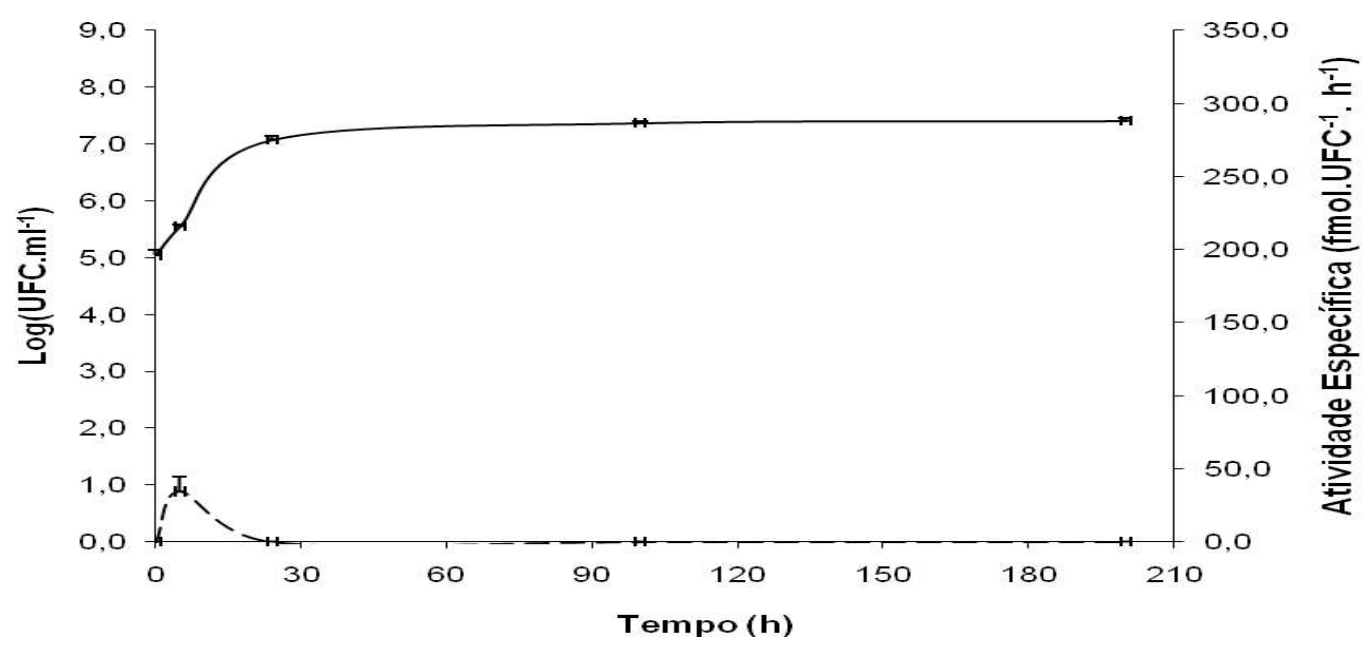


Figura 29 - Crescimento medido pelo Log (UFC) (-) e atividade específica (- - -) da enzima nitrogenase de Enterobacter sp. (ICB569) em função do tempo em meio MMS.

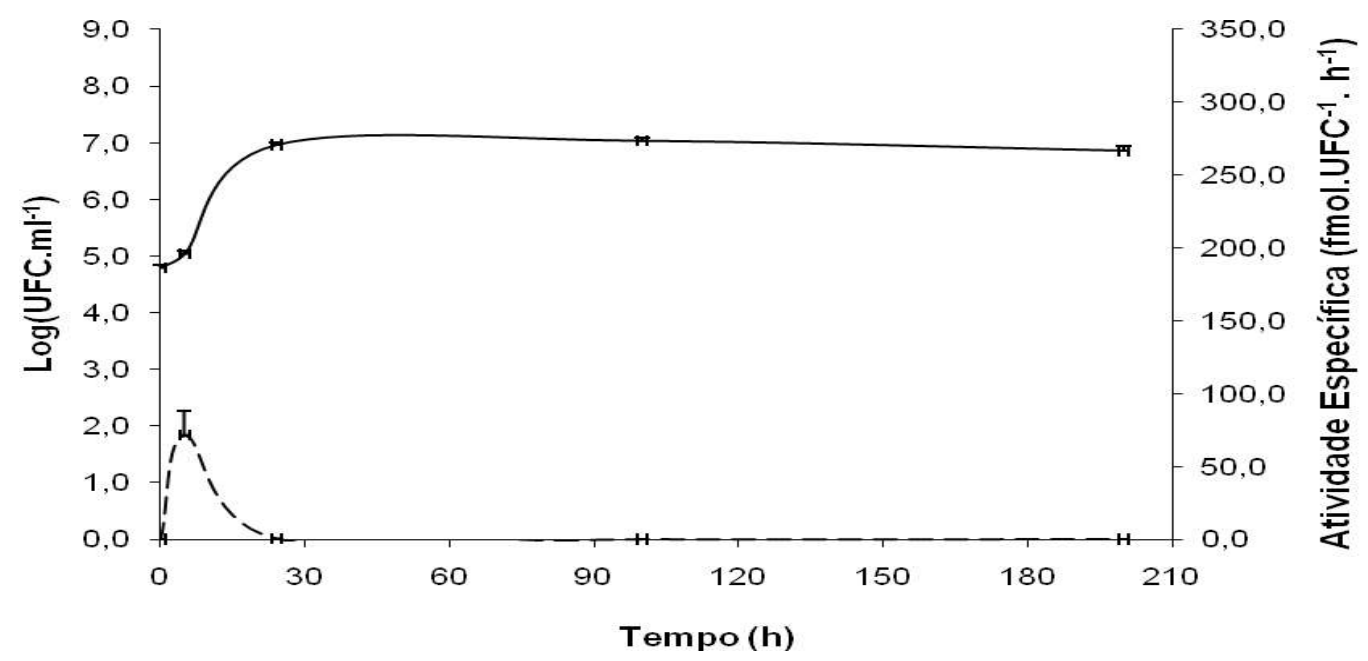

Figura 30 - Crescimento medido pelo Log (UFC) (-) e atividade específica (- - -) da enzima nitrogenase de Enterobacter sp. (ICB573) em função do tempo em meio MMS.

Seis linhagens do gênero Enterobacter liberaram aminoácidos. Os tempos em que os aminoácidos foram encontrados e suas concentrações variaram conforme a linhagem bacteriana. ICB22 excretou baixas quantidades (entre 0,01 e 0,025 $\mu \mathrm{g} \cdot \mathrm{ml}^{-1}$ ) de cinco aminoácidos deiferentes: Asp, Ser, Phe, lle e Leu, detectados apenas após 24 h de crescimento da cultura (Figura 31).

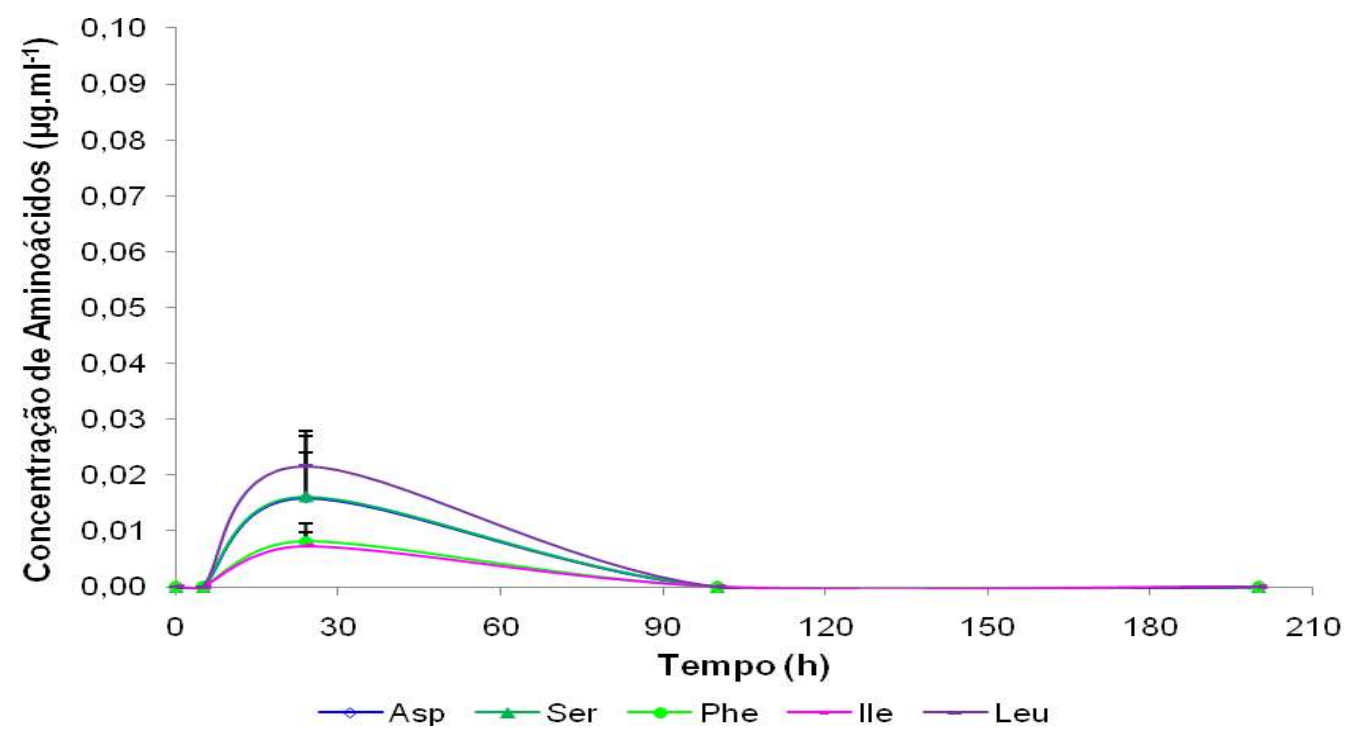


Figura 31 - Concentração de aminoácidos livres no meio ao longo do tempo em culturas de Enterobacter sp. (ICB22) em meio MMS.

Nenhuma outra linhagem de Enterobacter liberou mais que dois aminoácidos diferentes, porém em quantidades mais elevadas. As concentrações máximas detectadas foram de 0,66 $\mu \mathrm{g} \cdot \mathrm{ml}^{-1}$ de Gly em ICB118 (Figura 32), 0,42 $\mu \mathrm{g} \cdot \mathrm{ml}^{-1}$ de Asp em ICB479 (Figura 33) e 0,49 $\mu \mathrm{g} \cdot \mathrm{ml}^{-1}$ de Asp em ICB522 (Figura 34). ICB118 e ICB479 liberaram os aminoácidos na fase exponencial. Depois disso a concentração dessas substâncias diminuiu ou se manteve até o final do experimento (Figuras. 32 e 33). Em culturas de ICB522 a concentração de aminoácidos aumentou até 100h e, a seguir, não foi mais detectada (Figura 34). ICB525 e ICB567 liberaram dois aminoácidos diferentes cada.ICB118, ICB479 e ICB522 liberaram apenas um aminoácido cada.

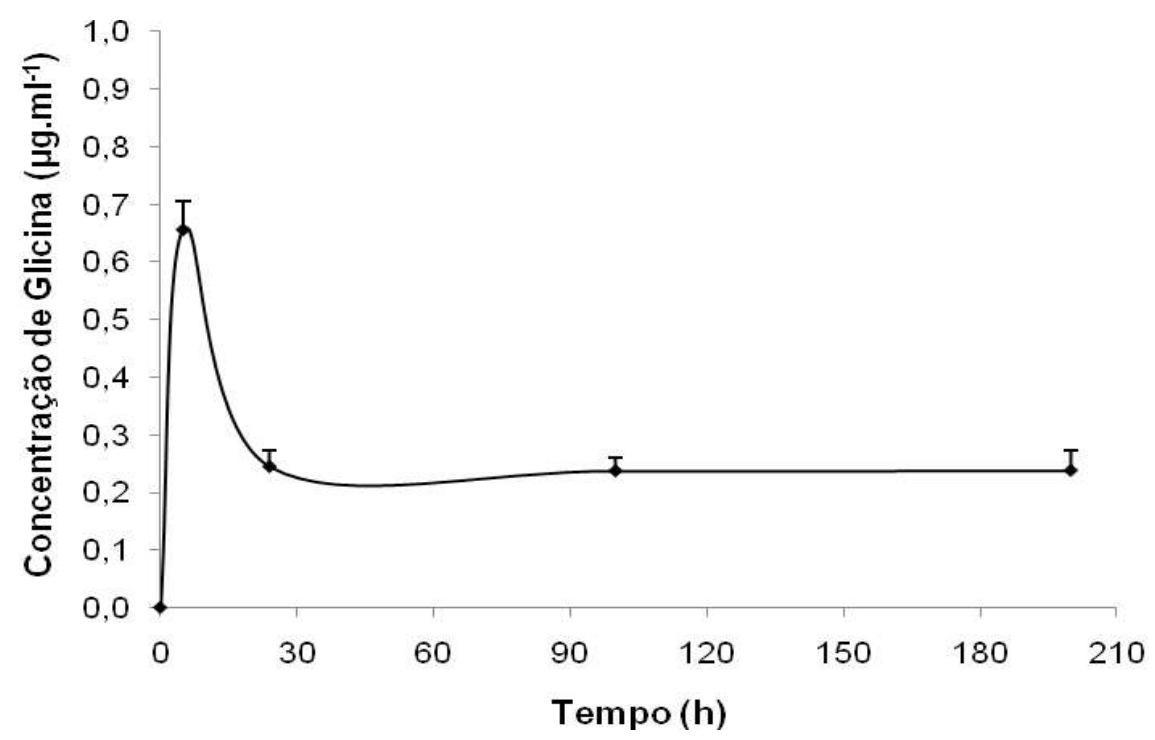

Figura 32 - Concentração de glicina livre no meio ao longo do tempo em culturas de Enterobacter sp. (ICB118) (-) em meio MMS. 


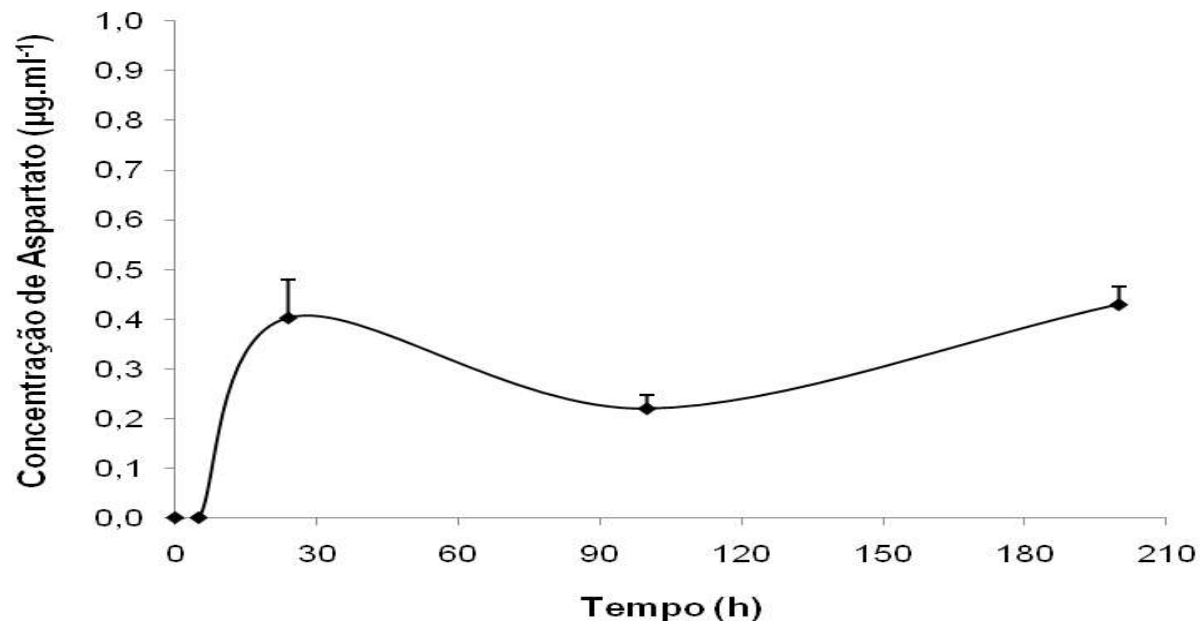

Figura 33 - Concentração de aspartato livre no meio ao longo do tempo em culturas de Enterobacter sp. (ICB479) (-) em meio MMS.

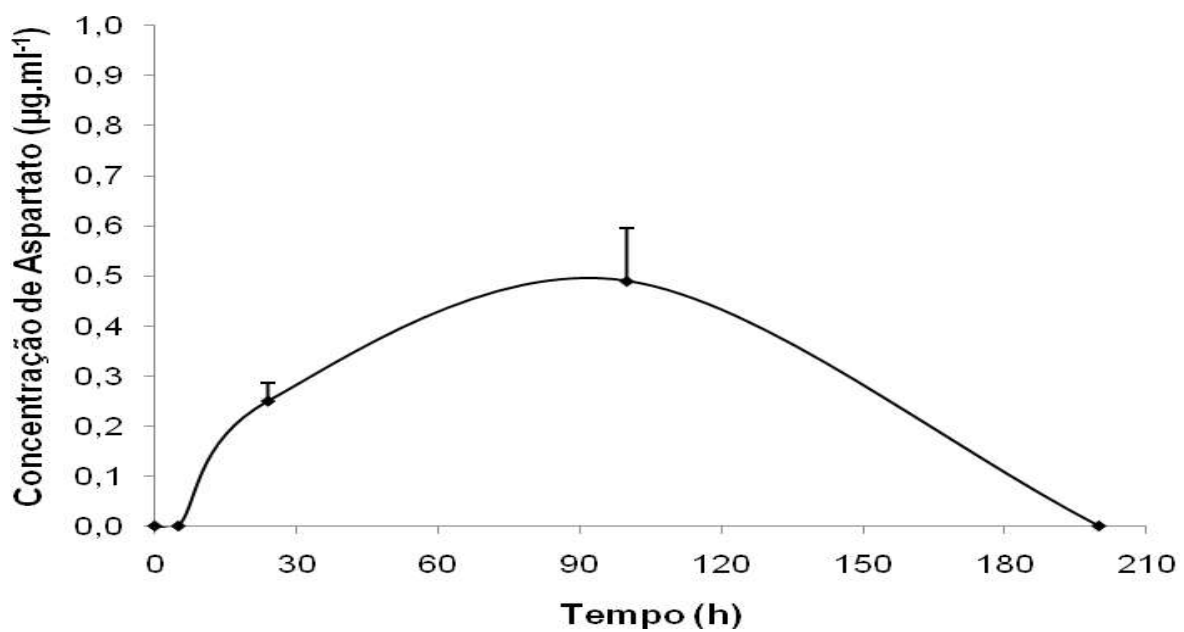

Figura 34 - Concentração de aspartato livre no meio ao longo do tempo em culturas de Enterobacter sp. (ICB522) (一) em meio MMS.

ICB525 excretou as maiores concentrações de aminoácidos detectadas no gênero Enterobacter, $1,03 \mu \mathrm{g} \cdot \mathrm{ml}^{-1}$ de Gly e $0,56 \mu \mathrm{g} \cdot \mathrm{ml}^{-1}$ de Ser nas primeiras $24 \mathrm{~h}$. Depois disso as concentrações desses compostos não se alteraram significativamente (Figura 35). ICB567 excretou 0,11 $\mu \mathrm{g} \cdot \mathrm{ml}^{-1}$ de Ala e Gly nas primeiras cinco horas de cultura. Entretanto esses valores caíram, e após 100h não havia mais aminoácidos no meio (Figura 36). 
Seguiu-se uma queda até o final do experimento (Figura 39).

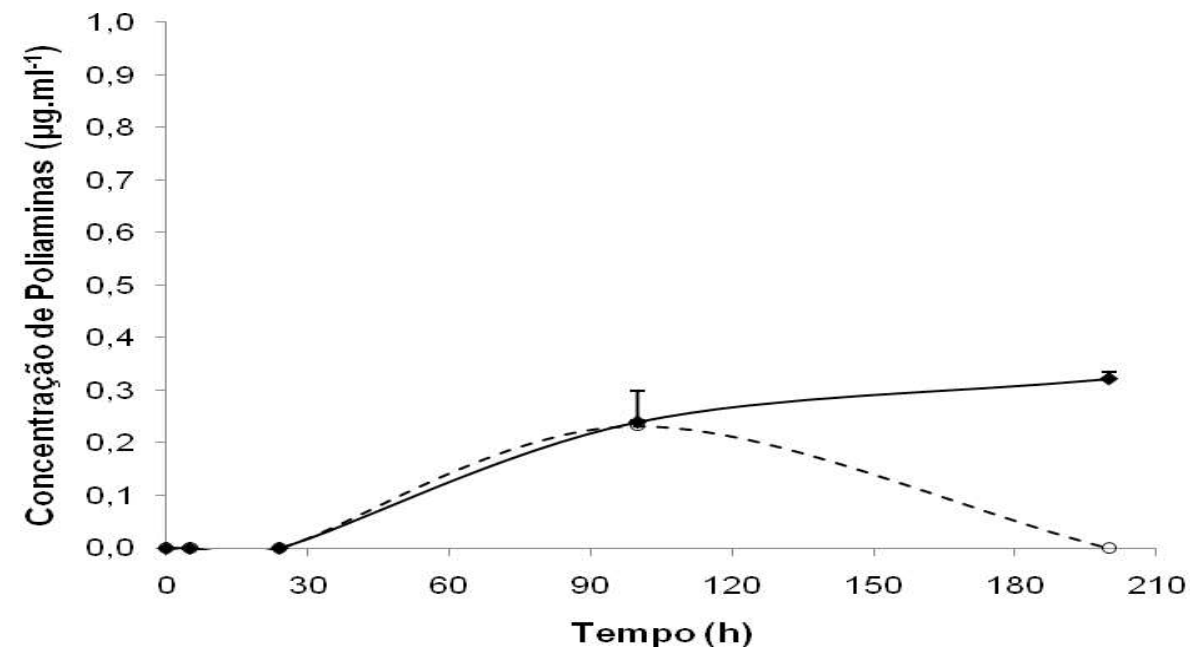

Figura 37 - Concentração de putrescina (-) e espermidina (- - -) livres no meio ao longo do tempo em culturas de Enterobacter sp. (ICB101) em meio MMS.

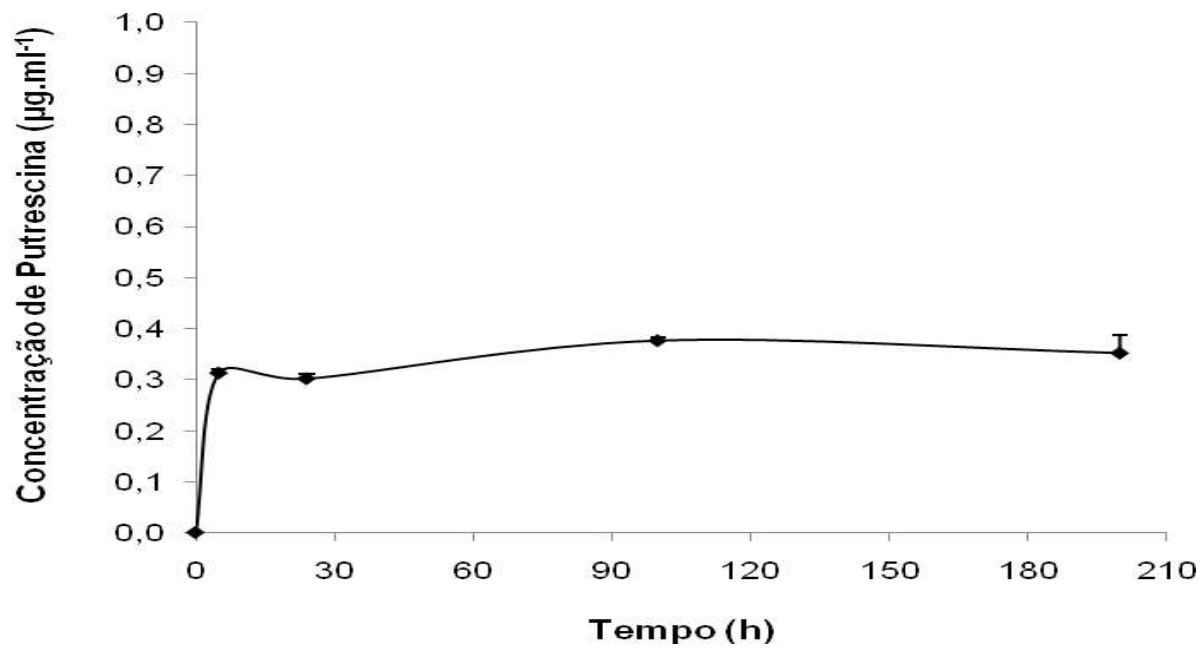

Figura 38 - Concentração da poliamina putrescina livre no meio ao longo do tempo em culturas de Enterobacter sp. (ICB118) em meio MMS (-).

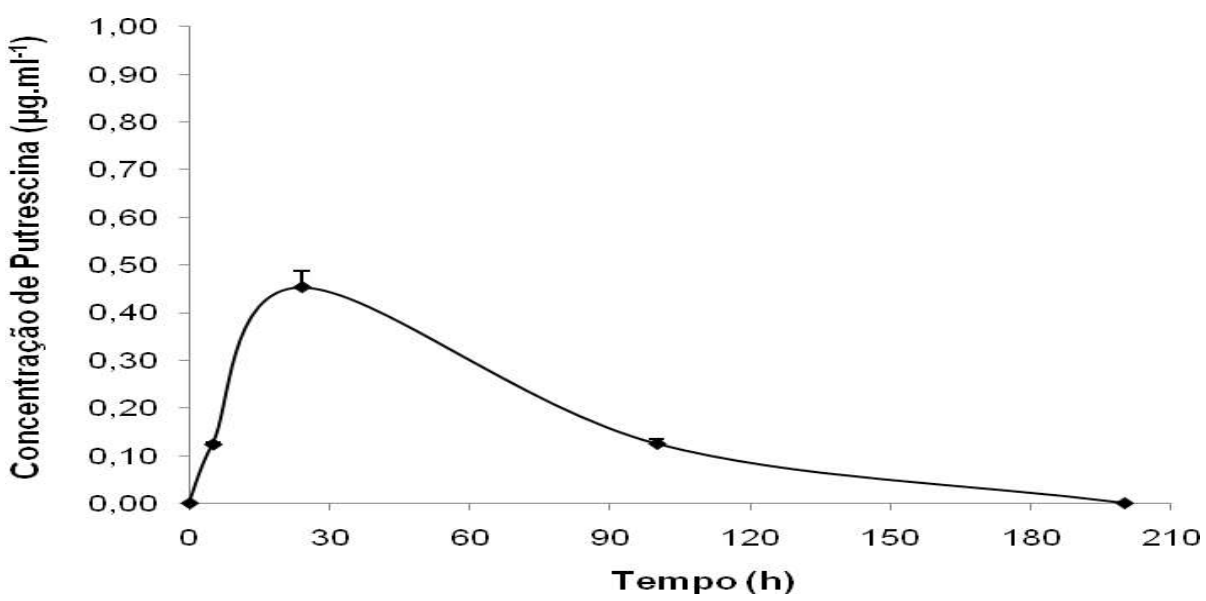

Figura 39 - Concentração da poliamina putrescina livre no meio ao longo do tempo em culturas de 
Enterobacter sp. (ICB405) em meio MMS (一).

Com exceção da linhagem ICB464, observou-se excreção de AIA por todas as bactérias do gênero Enterobacter em concentrações e tempos de liberação variados.

A figura 40 mostra as curvas de liberação de AIA de ICB22, ICB101, ICB105 e ICB118. Em todas ocorreu, entre cinco e 100h, um aumento da concentração do fitormônio. As concentrações ICBICB22, ICB101, ICB105 não se alteraram significativamente após esse período, enquanto ICB118 continuou produzindo AIA até 200h. As maiores concentrações de AIA detectadas em culturas de ICB22, ICB101,ICB105 e ICB118 foram 2,12 $\mu \mathrm{g} \cdot \mathrm{ml}^{-1}, 1,35 \mu \mathrm{g} \cdot \mathrm{ml}^{-1}, 3,87 \mu \mathrm{g} \cdot \mathrm{ml}^{-1}$ e $4,54 \mu \mathrm{g} \cdot \mathrm{ml}^{-1}$.

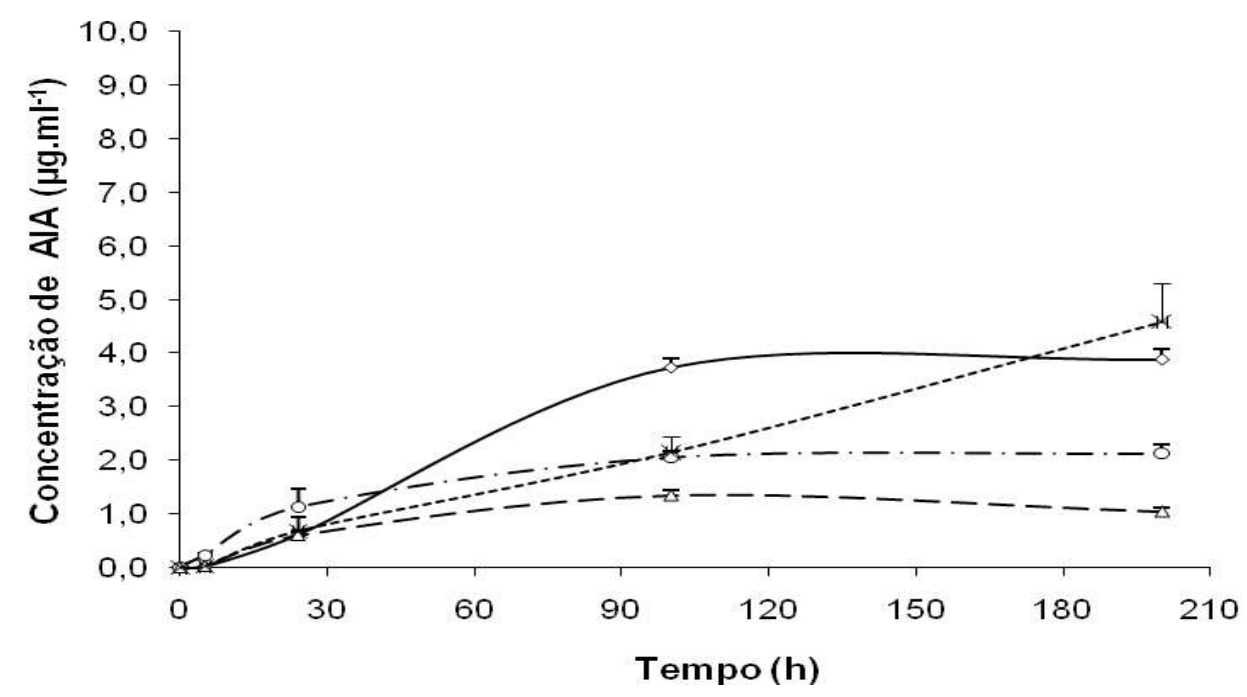

Figura 40 - Concentração de AIA livre detectada em meio MMS em função do tempo em culturas de Enterobacter sp.: ICB22 (- - -), ICB101 (- - ), ICB105 (-) e ICB118 (--.-)

A liberação de AIA pelas linhagens ICB405, ICB479, ICB481 e ICB522 está demonstrada na figura 41. ICB405 e ICB522 acumularam 4,01 $\mu \mathrm{g} \cdot \mathrm{ml}^{-1}$ e $5,59 \mu \mathrm{g} \cdot \mathrm{ml}^{-1}$, 
respectivamente, até $100 \mathrm{~h}$. Após $200 \mathrm{~h}$ a concentração do fitormônio caiu para valores próximos de $1,0 \mu \mathrm{g} \cdot \mathrm{ml}^{-1}$. ICB479 liberou AIA apenas nas primeiras $24 \mathrm{~h}$, quando as concentrações no meio chegaram a $0,38 \mu \mathrm{g} \cdot \mathrm{ml}^{-1}$. Depois disso, não houve alteração significativa da quantidade da AIA. ICB481 liberou AIA durante todo o experimento. O fitormônio foi detectado a partir de cinco horas e sua concentração chegou a 6,41 $\mu \mathrm{g} \cdot \mathrm{ml}^{-1}$.

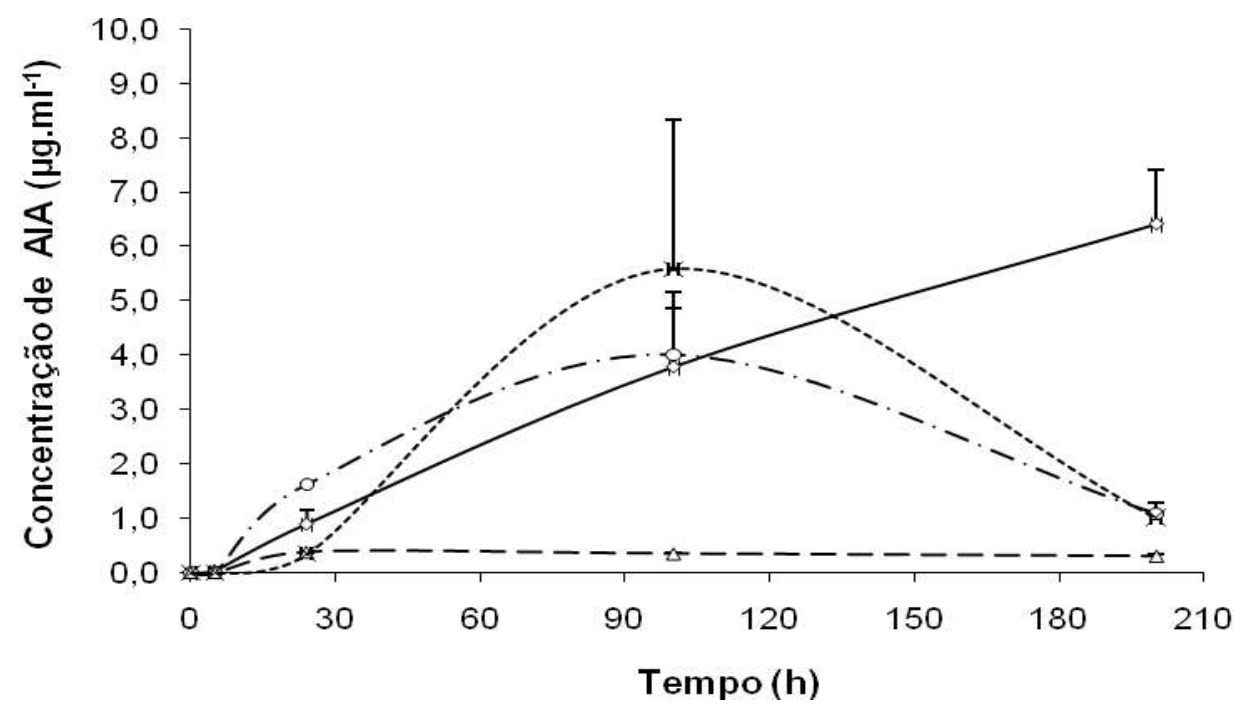

Figura 41 - Concentração de AIA livre detectada em meio MMS em função do tempo em culturas de Enterobacter sp.: ICB405 ( - -), ICB479 (- - ), ICB481 (- ) e ICB522 (- - - )

As linhagens ICB525, ICB528, ICB532 e ICB551 liberaram AIA conforme está demonstrado na figura 42. ICB525 e ICB528 excretaram o fitormônio até 100h quando houve uma queda. As concentrações máximas detectadas foram, respectivamente, $4,01 \mu \mathrm{g} \cdot \mathrm{ml}^{-1}$ e $5,20 \mu \mathrm{g} \cdot \mathrm{ml}^{-1}$. As quantidades aumentaram rapidamente nas culturas de ICB532 e ICB551 até 24h, chegando a 2,35 $\mu \mathrm{g} \cdot \mathrm{ml}^{-1}$ e $1,77 \mu \mathrm{g} \cdot \mathrm{ml}^{-1}$. Após $100 \mathrm{~h}$ a concentração de AIA na cultura de ICB532 diminuiu e não teve alteração significativa entre 100 e 200h, enquanto em ICB551 houve um pequeno acúmulo de hormônio que 
elevou sua concentração para $2,41 \mu \mathrm{g} \cdot \mathrm{ml}^{-1}$.

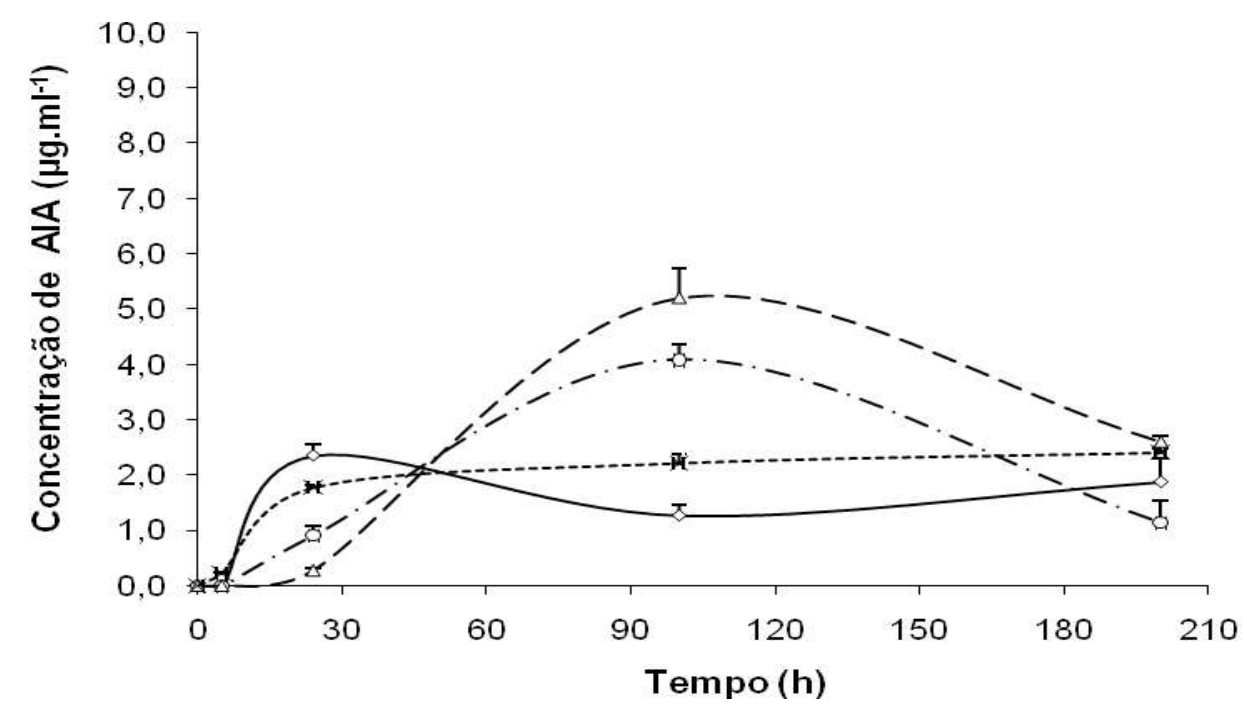

Figura 42 - Concentração de AIA livre detectada em meio MMS em função do tempo em culturas de Enterobacter sp.: ICB525 ( - - ), ICB528 (- - ), ICB532 $(-)$ e ICB551 (---)

A figura 43 mostra a liberação de AIA pelas linhagens ICB561, ICB567, ICB569 e ICB573. ICB561 e ICB567 acumularam este hormônio até 100h, tempo onde foram detectadas as concentrações máximas de $2,58 \mu \mathrm{g} \cdot \mathrm{ml}^{-1} \mathrm{e} 4,48 \mu \mathrm{g} \cdot \mathrm{ml}^{-1}$, respectivamente. Com 200h houve uma queda das concentrações de AIA no meio. O aumento da concentração de AIA na cultura de ICB569 ocorreu apenas na fase exponencial uma vez que não houve mais alteração na concentração do fitormônio até o final do experimento. Já em culturas de ICB573, após acúmulo nas primeiras $24 \mathrm{~h}$ a concentração de AIA caiu com $100 \mathrm{~h}$ e não teve mais mudanças significativas. As maiores concentrações de AIA detectadas em culturas de ICB569 e ICB573 foram de $2,07 \mu \mathrm{g} \cdot \mathrm{ml}^{-1}$ e $1,84 \mu \mathrm{g} \cdot \mathrm{ml}^{-1}$. 


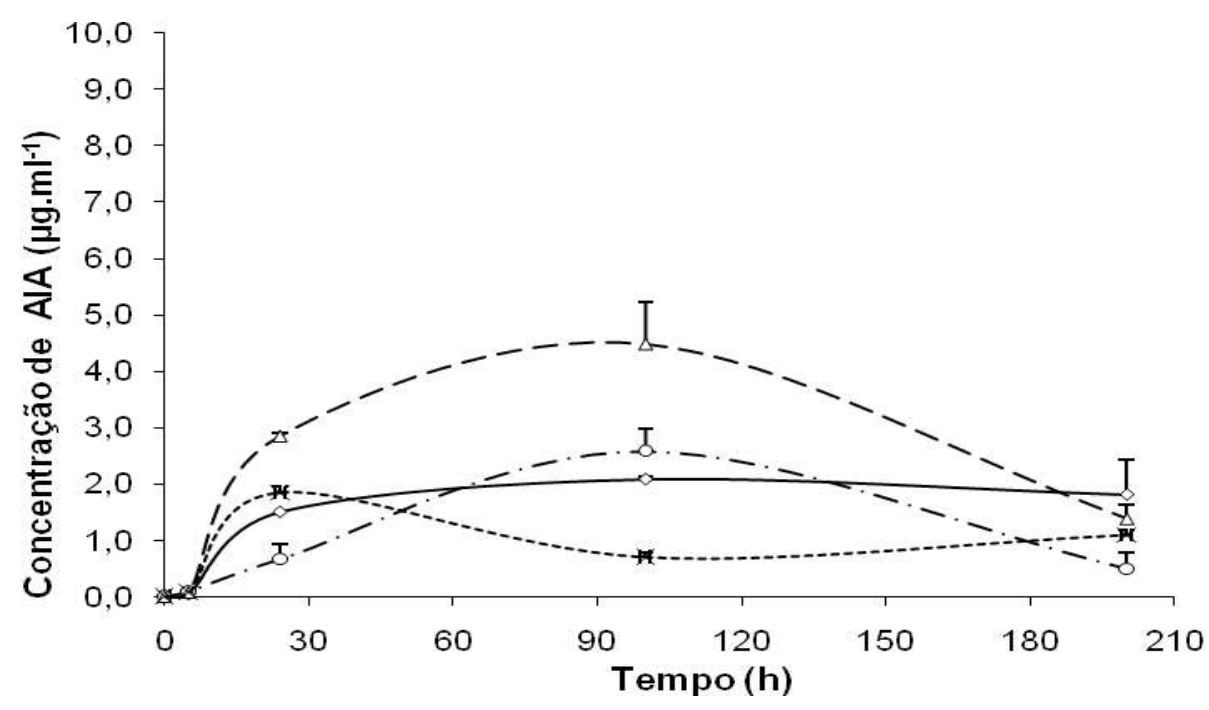

Figura 43 - Concentração de AIA livre detectada em meio MMS em função do tempo em culturas de Enterobacter sp.: ICB561 (- -); ICB567 (- -), ICB569 (- ) e ICB573 (-..-)

Cem por cento das linhagens de Enterobacter sp. produziram etileno. Em todas houve aumento da quantidade de hormônio entre 144 e 240h, entretanto essas variações nem sempre foram significativas. A tabela 5 mostra as concentrações de etileno detectadas nas culturas das linhagens de Enterobacter sp. Em geral as

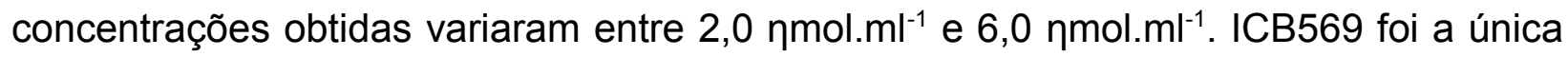
bactéria que liberou concentrações maiores que 6,0 nmol. $\mathrm{ml}^{-1}$, chegando a 12,93 $\eta$ nmol.ml-1 após 200h. Esta bactéria também foi a que apresentou maior aumento da concentração entre 144 e 240h, uma vez que no primeiro ponto foram detectados 1,63 nmol.ml ${ }^{-1}$. Quatro linhagens, ICB101, ICB464, ICB551 e ICB561, liberaram concentrações entre que 1,07 nmol.ml ${ }^{-1}$ e 1,26 nmol. $\mathrm{ml}^{-1}$. 

Tabela 5 - Concentrações de etileno detectadas em culturas de linhagens de Enterobacter sp. após 144 e $240 \mathrm{~h}$ e respectivo desvio padrão $(n=3)$.

\begin{tabular}{ccc} 
& \multicolumn{2}{c}{$\begin{array}{c}\text { Concentração de Etileno } \\
\left(\eta \text { mol.ml }^{-1}\right)\end{array}$} \\
\hline Linhagem & $144 \mathrm{~h}$ & $240 \mathrm{~h}$ \\
\hline ICB22 & $2,45 \pm 0,087$ & $3,29 \pm 1,497$ \\
ICB101 & $0,84 \pm 0,139$ & $1,26 \pm 0,043$ \\
ICB105 & $1,70 \pm 0,366$ & $2,29 \pm 1,179$ \\
ICB118 & $1,75 \pm 0,080$ & $4,09 \pm 1,642$ \\
ICB405 & $2,77 \pm 0,893$ & $3,48 \pm 0,438$ \\
ICB464 & $0,72 \pm 0,162$ & $1,26 \pm 0,147$ \\
ICB479 & $2,95 \pm 0,244$ & $4,63 \pm 0,062$ \\
ICB481 & $0,55 \pm 0,079$ & $2,22 \pm 0,136$ \\
ICB522 & $3,57 \pm 0,151$ & $5,15 \pm 0,649$ \\
ICB525 & $2,61 \pm 0,468$ & $4,51 \pm 1,013$ \\
ICB528 & $3,28 \pm 0,286$ & $5,68 \pm 0,046$ \\
ICB532 & $2,61 \pm 0,270$ & $4,04 \pm 0,104$ \\
ICB551 & $0,65 \pm 0,078$ & $1,18 \pm 0,159$ \\
ICB561 & $0,52 \pm 0,085$ & $1,07 \pm 0,046$ \\
ICB567 & $2,26 \pm 0,682$ & $5,19 \pm 1,509$ \\
ICB569 & $1,63 \pm 0,297$ & $12,93 \pm 2,222$ \\
ICB573 & $1,70 \pm 0,838$ & $2,07 \pm 0,984$ \\
\hline
\end{tabular}

\section{c) Klebsiella}

As oito linhagens de Klebsiella estudadas apresentaram curvas crescimento e atividades específicas da nitrogenase bastante distintas entre si.

Todas as linhagens atingiram populações máximas entre $1,0.10^{7}$ e $1,0.10^{8}$ UFC. $\mathrm{ml}^{-1}$. Os perfis das fases estacionárias variaram entre quedas leves (Figura 44, 45, 46, 47, 48 e 49) e estabilidade (Figura 50 e 51).

A atividade da nitrogenase foi detectada em sete linhagens, sendo ICB115 a única a que não reduziu acetileno em nenhuma das medidas feitas (Figura 44). As demais linhagens apresentaram a enzima ativa, principalmente na fase exponencial. 
No entanto, os valores de acetileno reduzido foram muito variados: ICB365, ICB439 e ICB553 reduziram menos de 40 fmol.UFC-1.h-1 de acetileno (Figuras 45, 48 e 49); ICB369, ICB375 e ICB565 reduziram entre 40 e 100 fmol.UFC-1.h-1 de acetileno (Figuras 46, 47 e 50); e ICB572 foi a linhagem de Klebsiella mais ativa, reduzindo 163,85 fmol.UFC-1.h-1 (Figura 51).

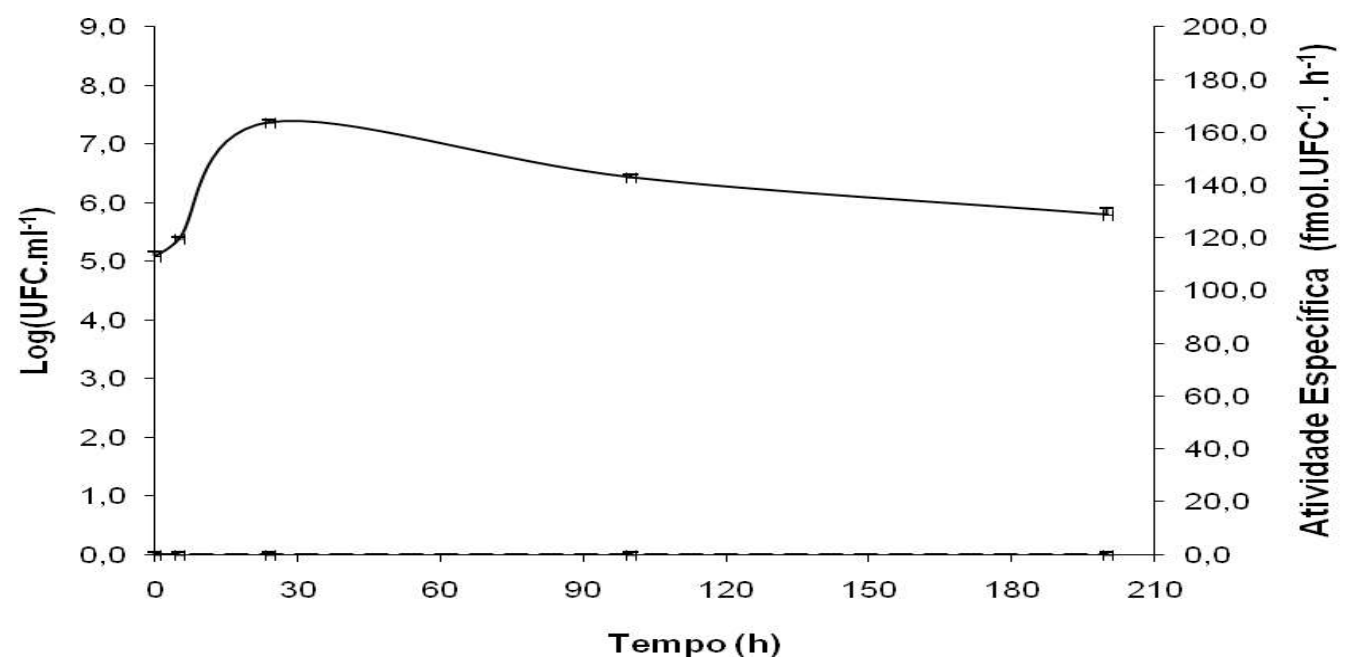

Figura 44 - Crescimento medido pelo Log (UFC) (-) e atividade específica (- - -) da enzima nitrogenase de Klebsiella sp. (ICB115) em função do tempo em meio MMS.

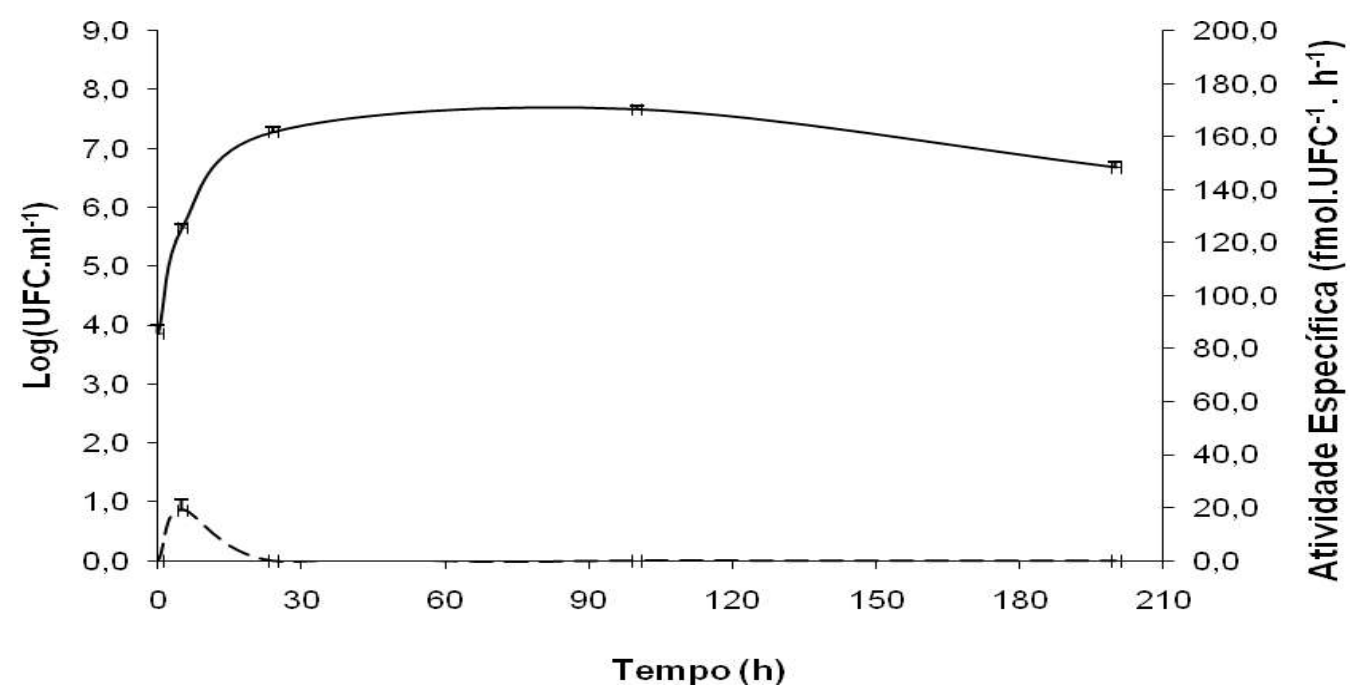

Figura 45 - Crescimento medido pelo Log (UFC) (-) e atividade específica (- - -) da enzima nitrogenase de Klebsiella sp. (ICB365) em função do tempo em meio MMS. 


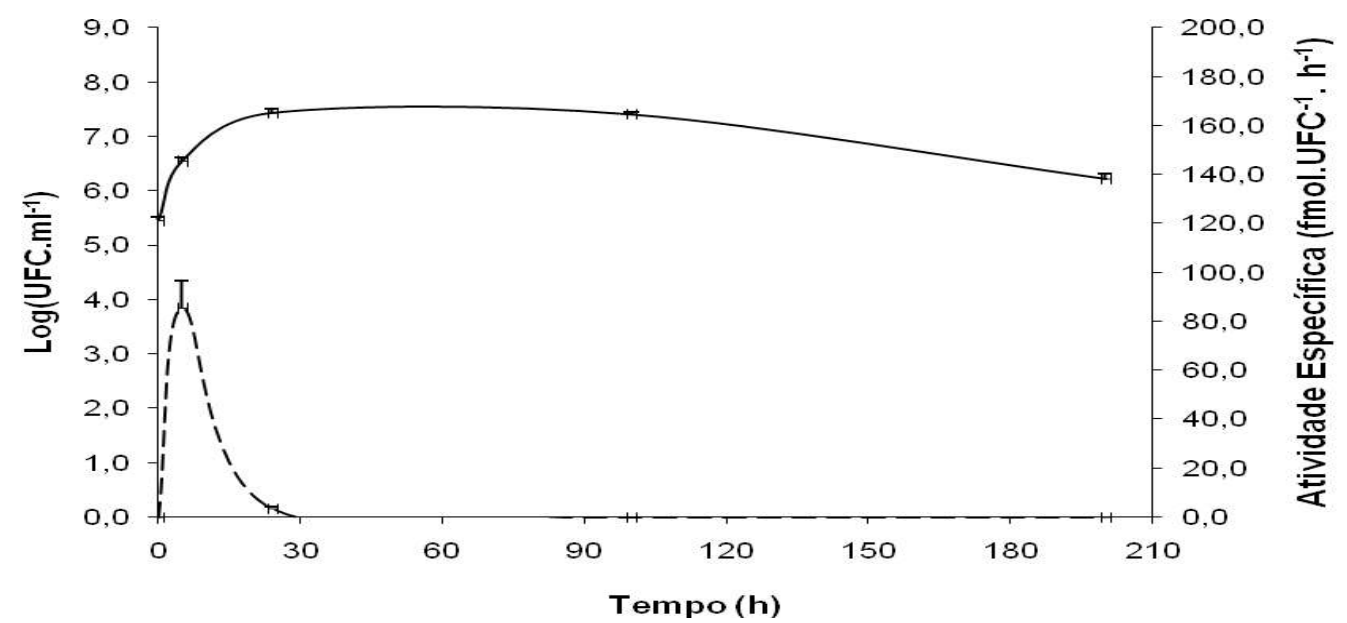

Figura 46 - Crescimento medido pelo Log (UFC) (-) e atividade específica (- - -) da enzima nitrogenase de Klebsiella sp. (ICB369) em função do tempo em meio MMS.

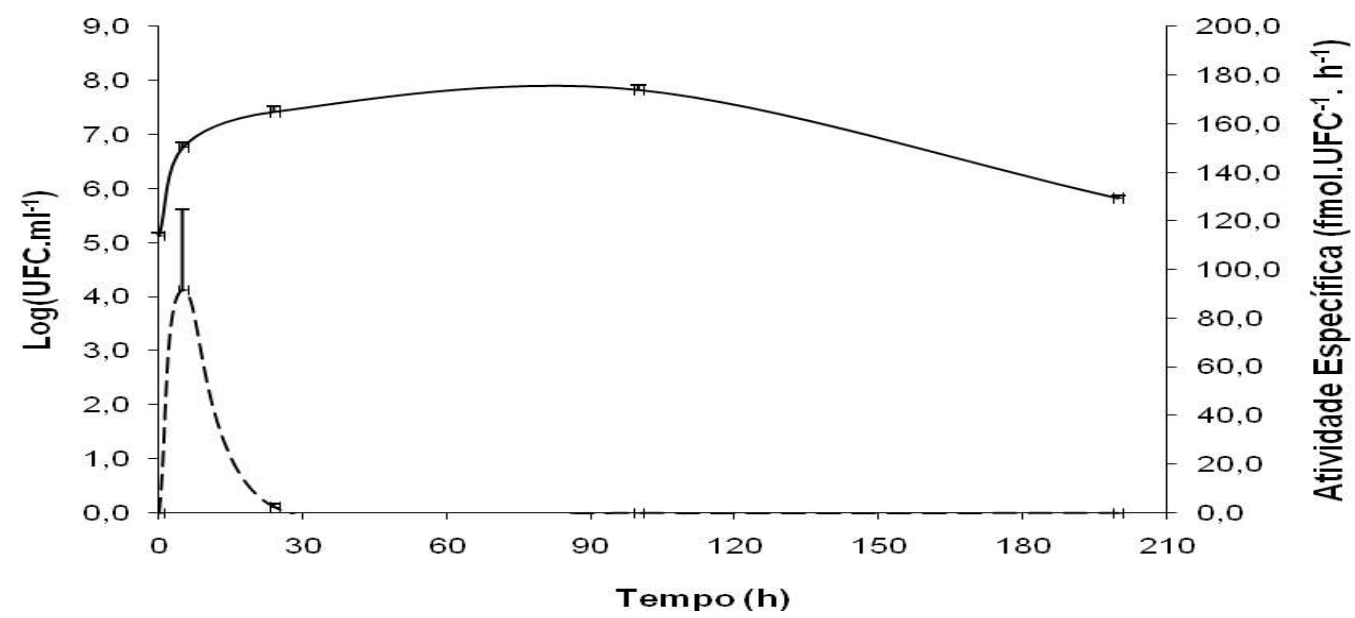

Figura 47 - Crescimento medido pelo Log (UFC) (-) e atividade específica (- - -) da enzima nitrogenase de Klebsiella sp. (ICB375) em função do tempo em meio MMS.

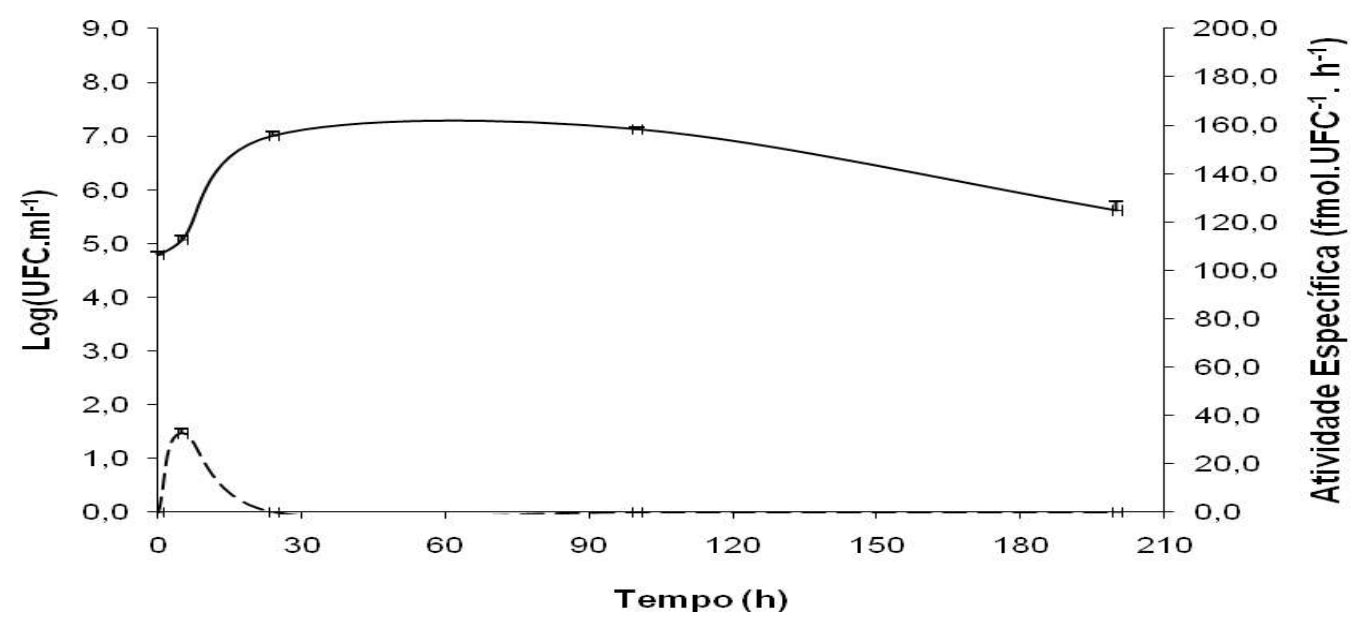

Figura 48 - Crescimento medido pelo Log (UFC) (-) e atividade específica (- - -) da enzima nitrogenase de Klebsiella sp. (ICB439) em função do tempo em meio MMS. 


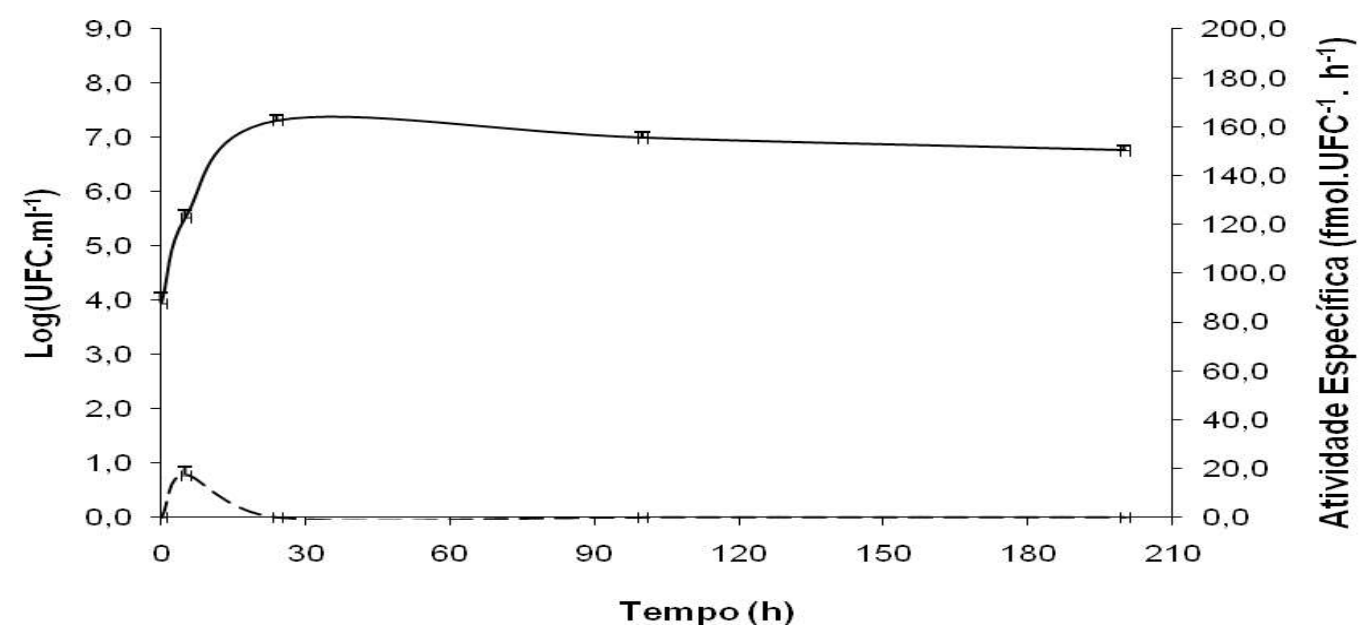

Figura 49 - Crescimento medido pelo Log (UFC) (-) e atividade específica (- - -) da enzima nitrogenase de Klebsiella sp. (ICB553) em função do tempo em meio MMS.

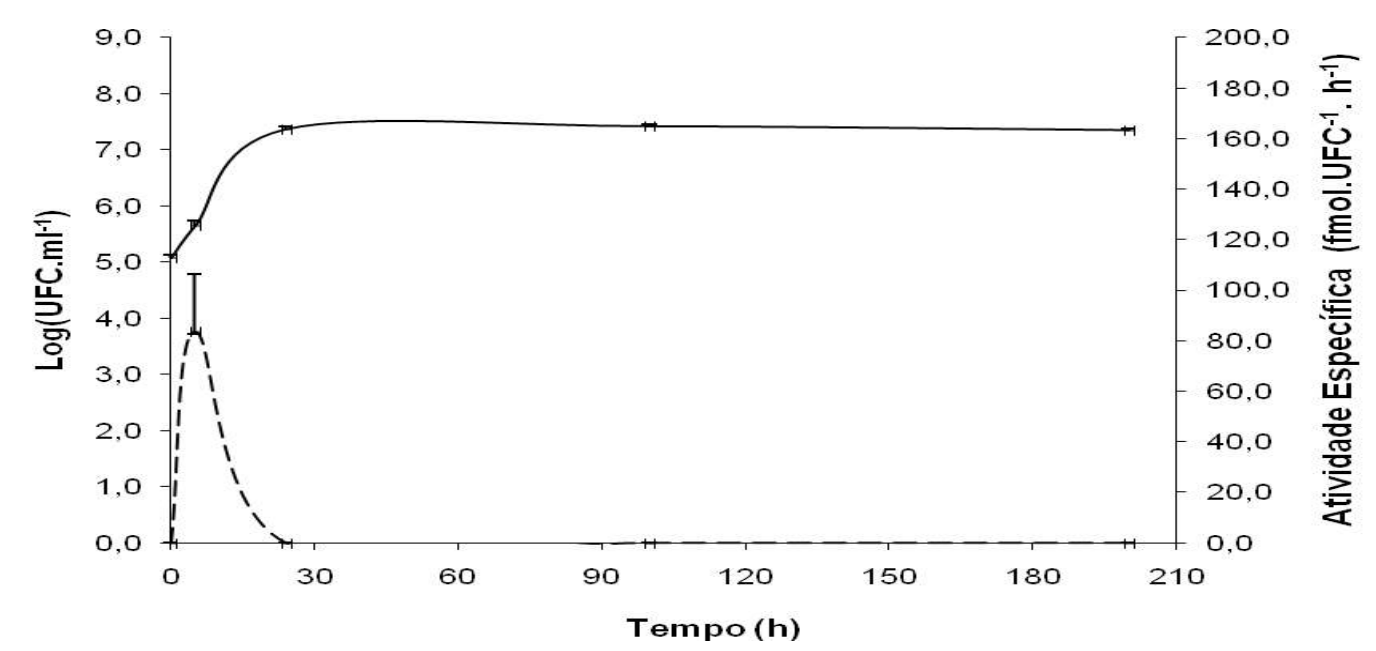

Figura 50 - Crescimento medido pelo Log (UFC) (-) e atividade específica (- - -) da enzima nitrogenase de Klebsiella sp. (ICB565) em função do tempo em meio MMS.

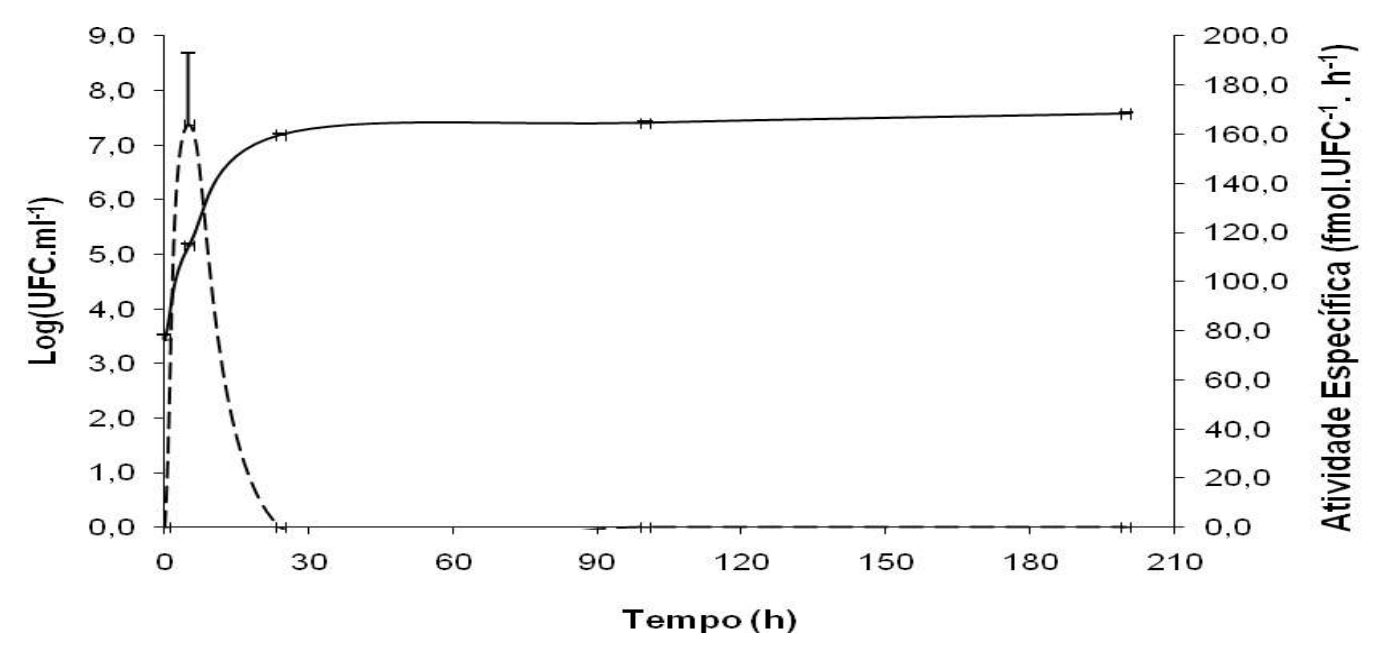

Figura 51 - Crescimento medido pelo Log (UFC) (-) e atividade específica (- - -) da enzima nitrogenase de Klebsiella sp. (ICB572) em função do tempo em meio MMS. 
Quatro isolados de Klebsiella sp. mostraram-se capazes de liberar aminoácidos. Após $200 \mathrm{~h}$ de cultivo ICB115 foi a que liberou maior variedade de aminoácidos (Asp, Glu, Trp e Val). As excreções ocorreram em concentrações que variaram entre 0,01 e $0,03 \mu \mathrm{g} \cdot \mathrm{ml}^{-1}$ dependendo do aminoácido (Figura 52).

ICB365 e ICB369 foram capazes de excretar dois aminoácidos diferentes cada. ICB365 excretou, respectivamente, concentrações de 0,08 e 0,03 $\mu \mathrm{g} \cdot \mathrm{ml}^{-1}$ de Glu e Phe, após 200h (Figura 53). Em culturas de ICB369, Asp e Glu foram detectados a partir de 100h e chegaram a concentrações de 0,04 e 0,23 $\mu \mathrm{g} \cdot \mathrm{ml}^{-1}$, respectivamente (Figura 54).

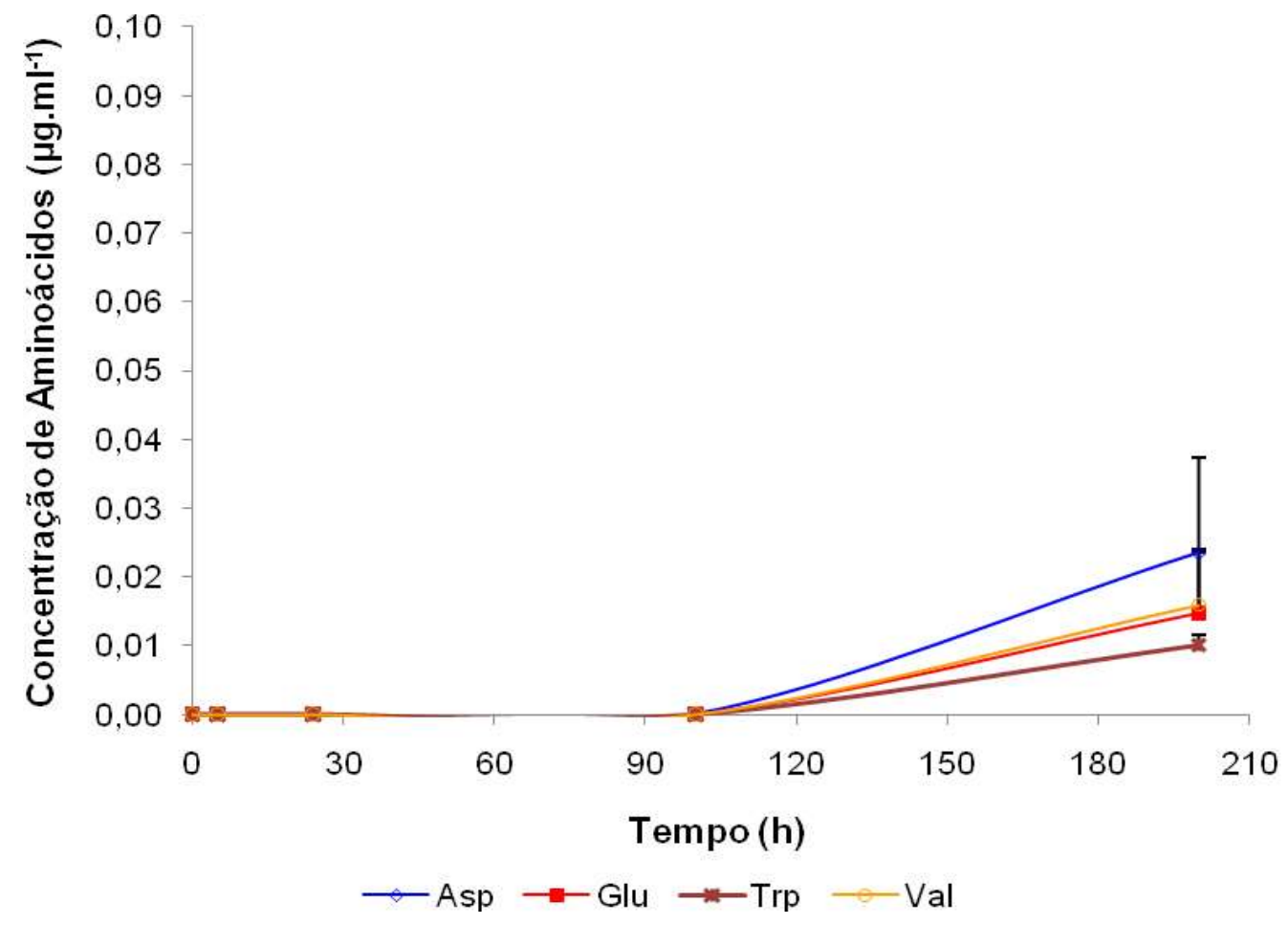

Figura 52 - Concentração de aminoácidos livres no meio ao longo do tempo em culturas de Klebsiella sp. (ICB115) em meio MMS. 


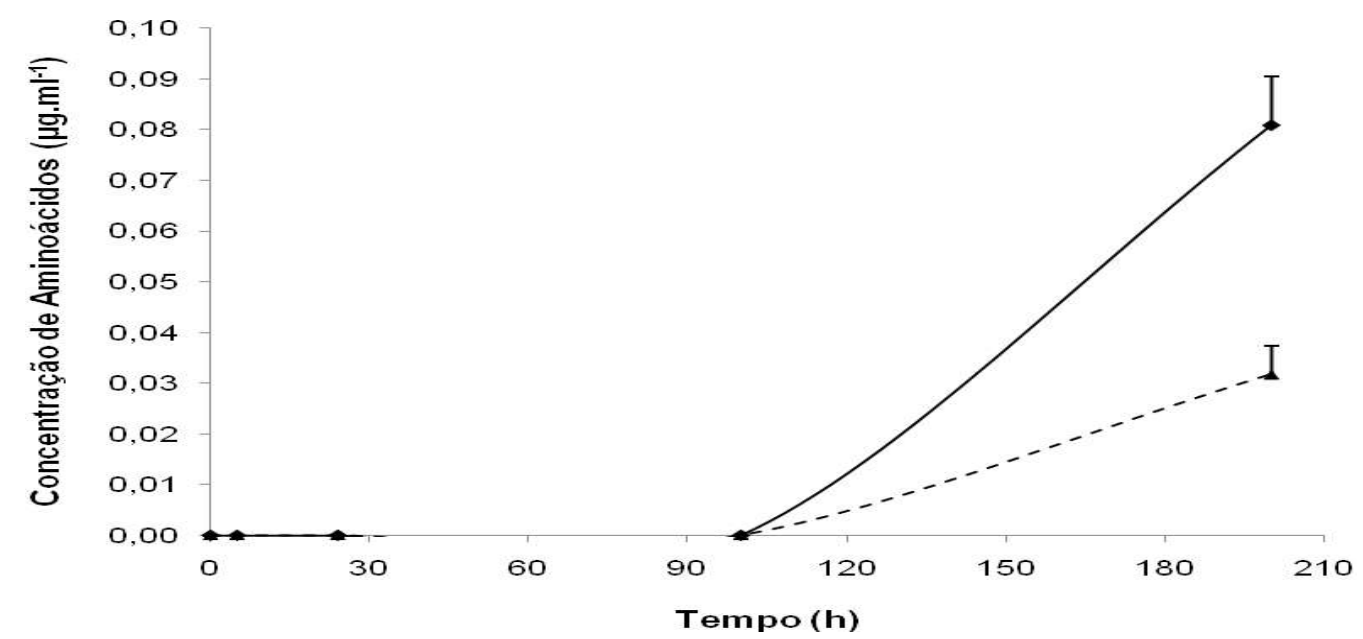

Figura 53 - Concentração de glutamato (-) e fenilalanina (- - -) livres no meio ao longo do tempo em culturas de Klebsiella sp. (ICB365) em meio MMS.

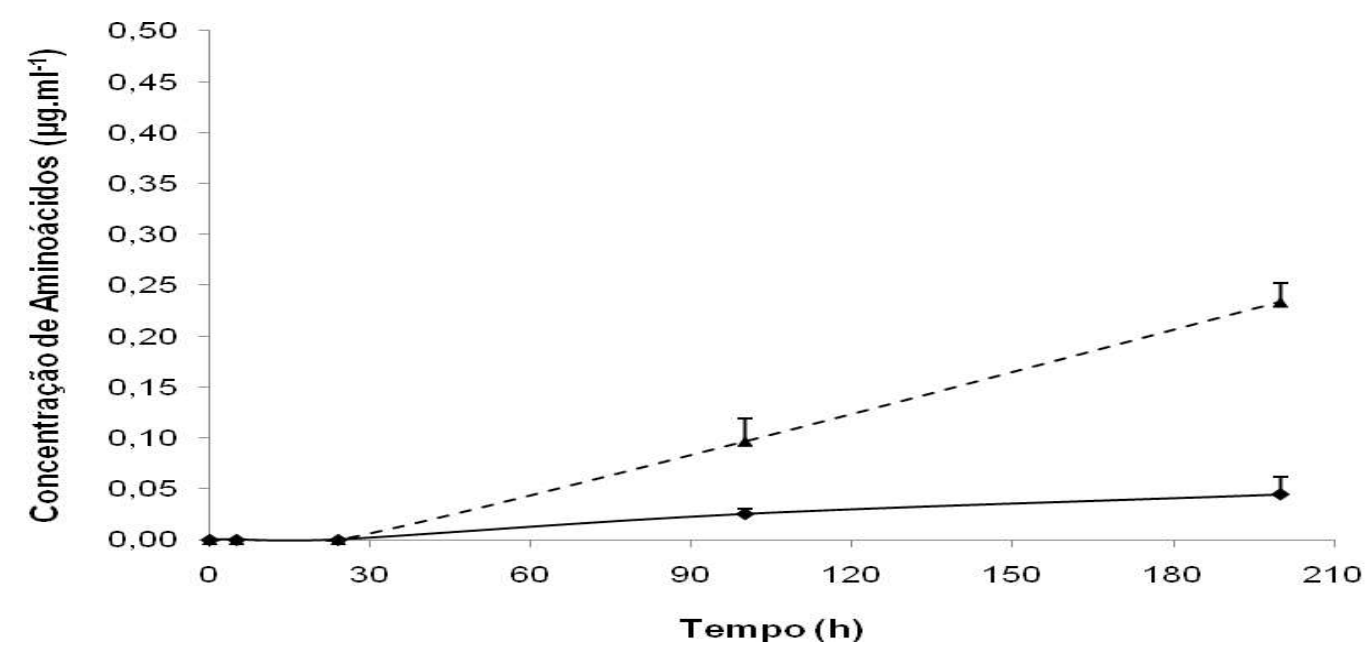

Figura 54 - Concentração de aspartato (-) e glutamato (- - -) livres no meio ao longo do tempo em culturas de Klebsiella sp. (ICB369) em meio MMS.

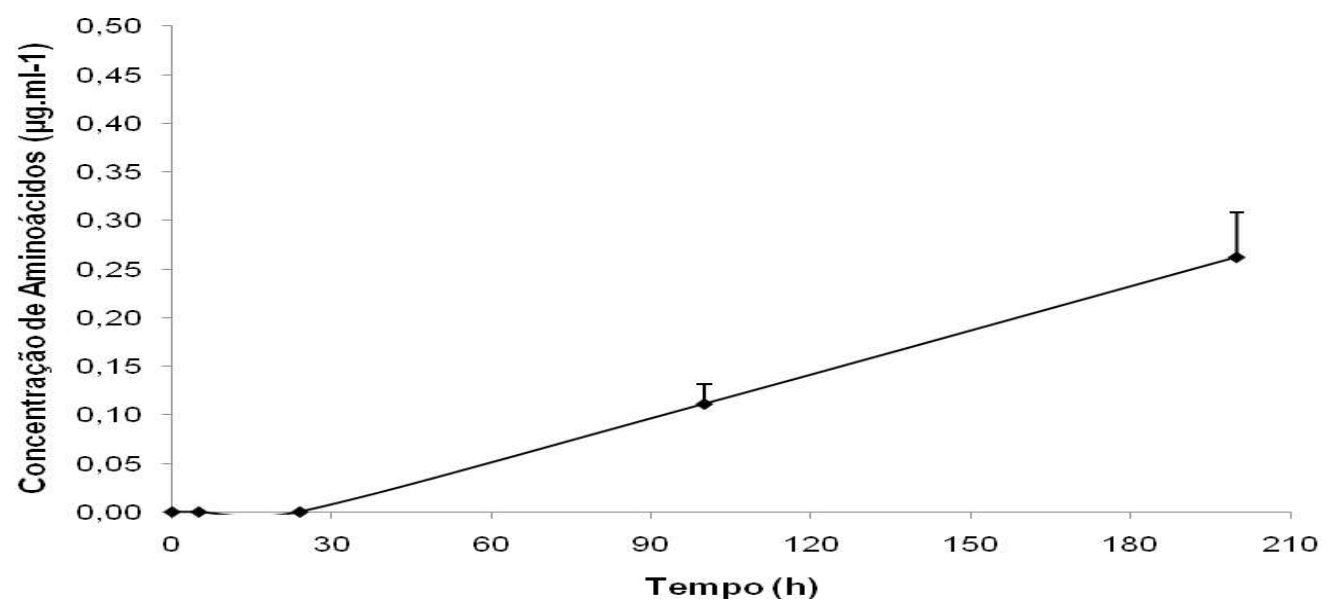

Figura 55 - Concentração de aspartato livre no meio ao longo do tempo em culturas de Klebsiella sp. (ICB375) (一) em meio MMS. 
ICB375 liberou apenas Asp, que foi detectado inicialmente com 100h e atingiu um valor máximo de $0,26 \mu \mathrm{g} \cdot \mathrm{ml}^{-1}$ após $200 \mathrm{~h}$ (Figura 55).

As mesmas quatro linhagens que excretaram aminoácidos, também liberaram poliaminas. ICB115 e ICB369 produziram 0,54 e 0,52 $\mu \mathrm{g} \cdot \mathrm{ml}^{-1}$ de Put, respectivamente, entre 24 e 100h, concentrações estas, que se estabilizaram. (Figura 56 e 58). ICB365 apresentou um perfil diferente de liberação de Put em função do tempo: iniciou na fase exponencial e aumentou até o final do experimento chegando a 1,91 $\mu \mathrm{g} \cdot \mathrm{ml}^{-1}$ (Figura 57). ICB375 liberou Put apenas após 200h de crescimento, atingindo uma concentração de $0,63 \mu \mathrm{g} \cdot \mathrm{ml}^{-1}$ (Figura 59).

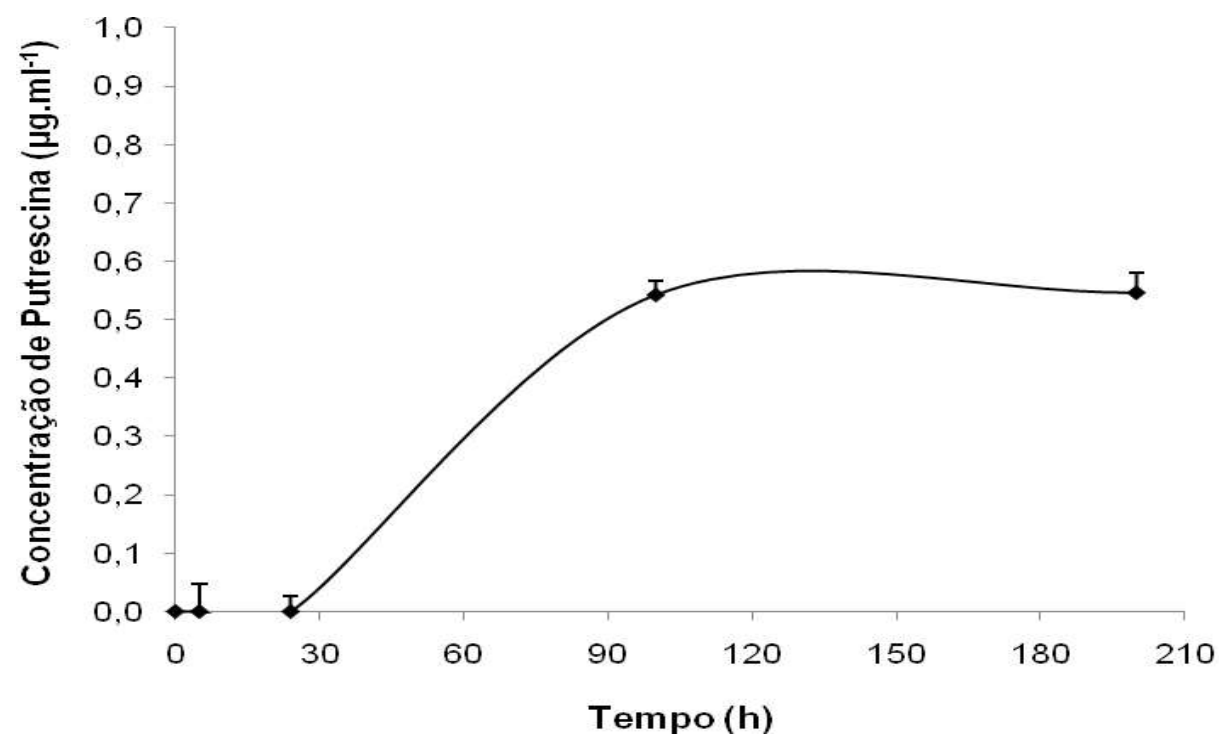

Figura 56 - Concentração da poliamina putrescina livre no meio ao longo do tempo em culturas de Klebsiella sp. (ICB115) em meio MMS (-). 


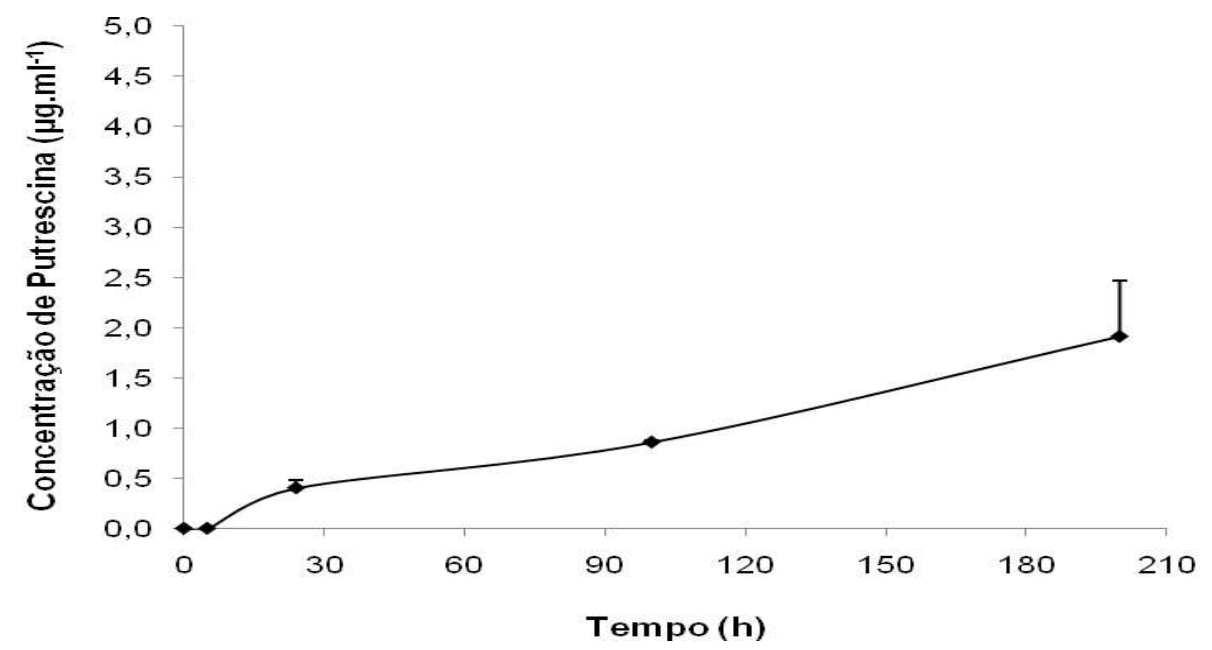

Figura 57 - Concentração da poliamina putrescina livre no meio ao longo do tempo em culturas de Klebsiella sp. (ICB365) em meio MMS (一).

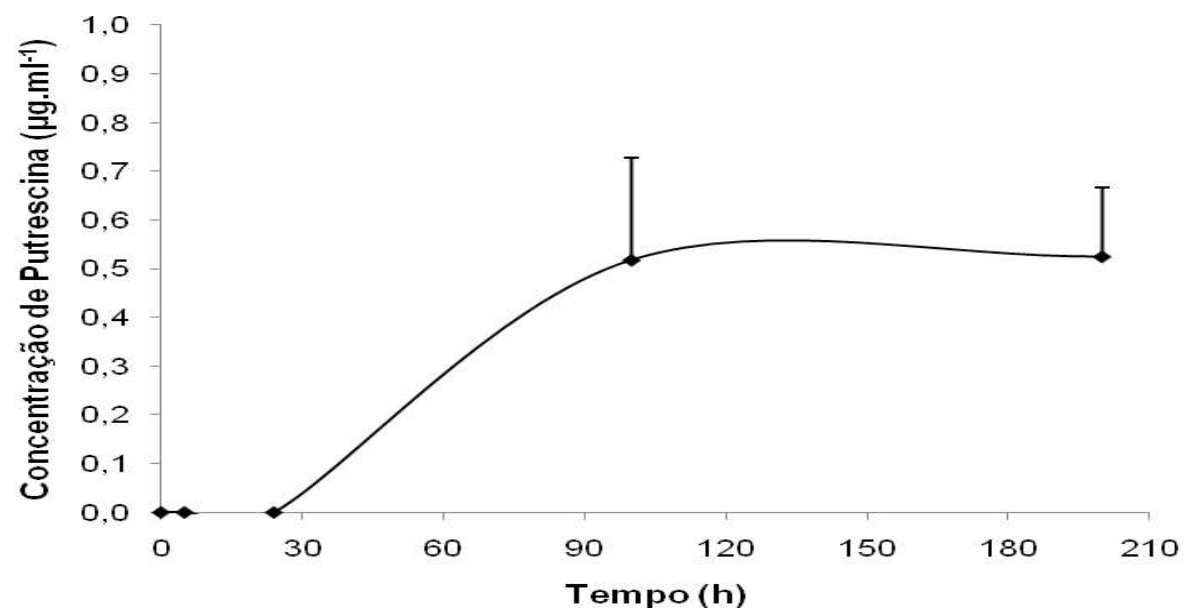

Figura 58 - Concentração da poliamina putrescina livre no meio ao longo do tempo em culturas de Klebsiella sp. (ICB369) em meio MMS (一).

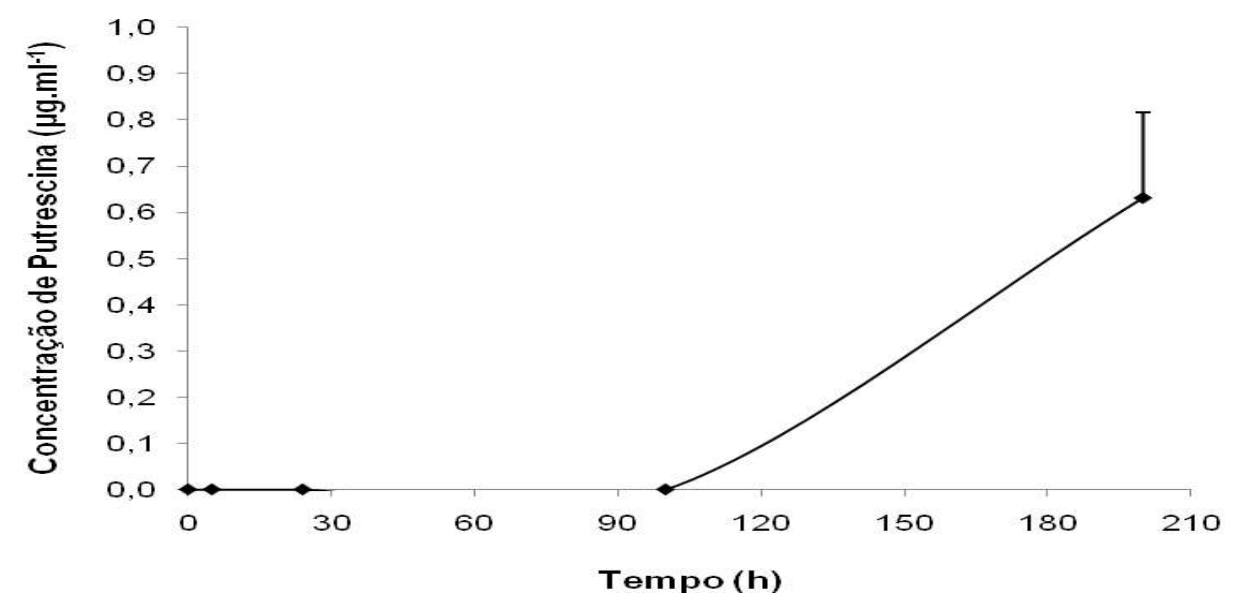

Figura 59 - Concentração da poliamina putrescina livre no meio ao longo do tempo em culturas de Klebsiella sp. (ICB375) em meio MMS (-). 
As oito linhagens de Klebsiella excretaram AlA a partir de 5h. A figura 60 mostra as concentrações desse hormônio detectadas nas culturas de ICB115, ICB365, ICB369 e ICB375. O primeiro valor detectado para culturas de ICB115 foi de $0,02 \mu \mathrm{g} \cdot \mathrm{ml}^{-1}$ e sua excreção perdurou por todo o experimento, atingindo $1,39 \mu \mathrm{g} \cdot \mathrm{ml}^{-1}$. A liberação de AIA nas culturas de ICB365 ocorreu também, durante todo o tempo de medida, porém, o aumento detectado a partir de $100 \mathrm{~h}$ não foi significativo. Às $200 \mathrm{~h}$, a concentração foi de 13,67 $\mu \mathrm{g} \cdot \mathrm{ml}^{-1}$. ICB369 foi a bactéria dentre todas as estudadas que liberou a maior quantidade de AIA: 15,02 $\mu \mathrm{g} \cdot \mathrm{ml}^{-1}$, durante a fase exponencial; em 200h, houve queda na concentração, reduzida a 7,03 $\mu \mathrm{g} \cdot \mathrm{ml}^{-1}$. O AIA detectado em culturas de ICB375 aumentou acentuadamente até $24 \mathrm{~h}$, e ligeiramente até $200 \mathrm{~h}$, chegando a $9,75 \mu \mathrm{g} \cdot \mathrm{ml}^{-1}$.

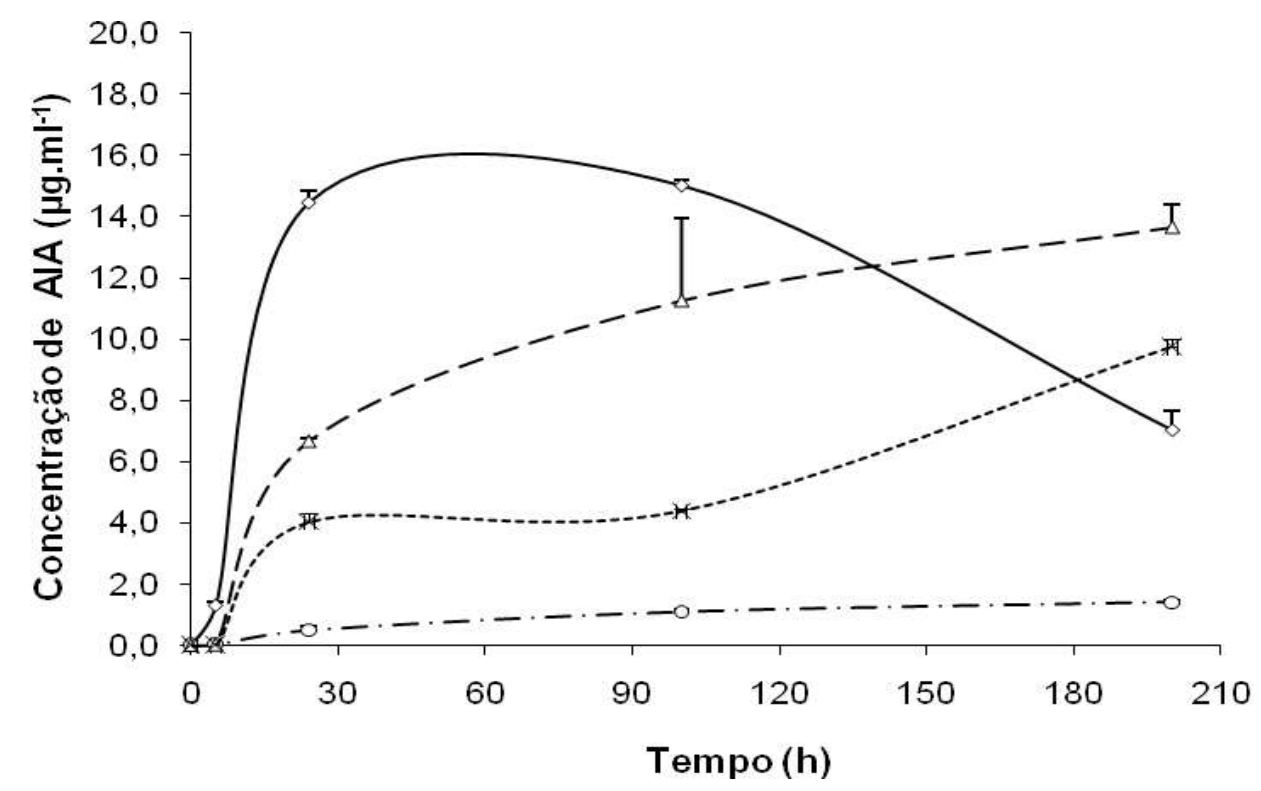

Figura 60 - Concentração de AIA livre detectada em meio MMS em função do tempo em culturas de Klebsiella sp.: ICB115 ( - - -), ICB365 ( - - ), ICB369 (- ) e ICB375 (-- - ) 
As curvas de liberação de AIA dos isolados ICB439, ICB553, ICB565 e ICB572 estão demonstradas na figura 61. ICB439 e ICB572 aumentaram a concentração até 100h. As concentrações máximas detectadas nas culturas de ICB572 foram elevadas, atingindo 8,94 $\mu \mathrm{g} \cdot \mathrm{ml}^{-1}$. ICB439 liberou apenas 1,39 $\mu \mathrm{g} \cdot \mathrm{ml}^{-1}$. ICB553 acumulou AIA até o final do experimento. A liberação do hormônio por essa bactéria foi detectada inicialmente com 24h atingindo $6,37 \mu \mathrm{g} \cdot \mathrm{ml}^{-1} \mathrm{em} \mathrm{200h}$. ICB565 liberou concentrações de até $8,94 \mu \mathrm{g} \cdot \mathrm{ml}^{-1}$ em até $100 \mathrm{~h}$, porém, caindo após esse período, para apenas 2,42 $\mu g \cdot \mathrm{ml}^{-1}$.

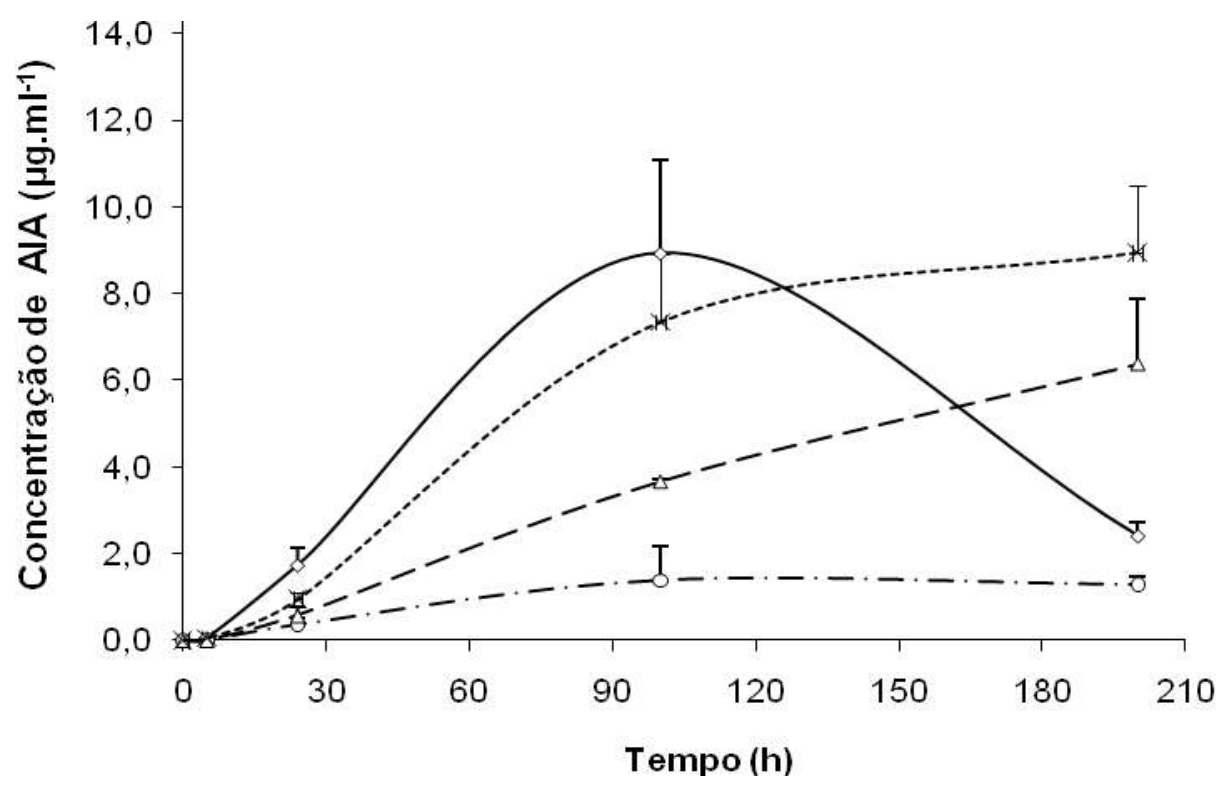

Figura 61 - Concentração de AIA livre detectada em meio MMS em função do tempo em culturas de Klebsiella sp.: ICB439 ( - - -), ICB553 ( - - ), ICB565 (-) e ICB572 (- - - )

O etileno, assim como o AIA, foi produzido pelas oito linhagens de Klebsiella sp. estudadas. Todas as linhagens apresentaram aumento da concentração entre 144 e 240h exceto ICB365, que não alterou significativamente a quantidade dessa substância nas culturas. As concentrações liberadas variaram entre 1,26 e 8,38 nmol.ml $^{-1}$ (Tabela $6)$. 


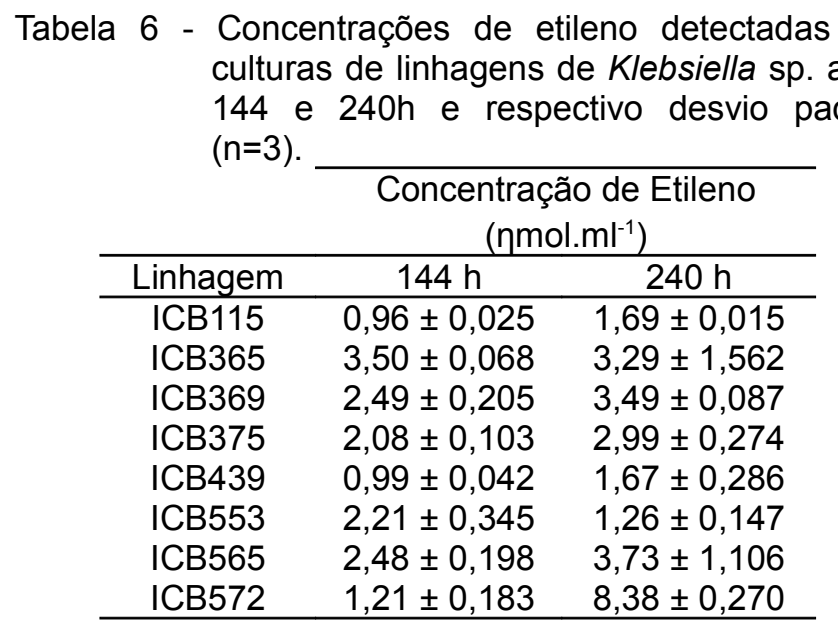

\section{d) Acinetobacter}

Apenas uma linhagem deste gênero foi estudada, (ICB117) Sua curva de crescimento (Figura 62) mostra que após o aumento populacional nas primeiras $24 \mathrm{~h}$ onde alcançou 2,8. $10^{7}$ UFC. $\mathrm{ml}^{-1}$ ocorreu uma queda no número, confirmada após 200h, quando não foram detectadas células viáveis na cultura.

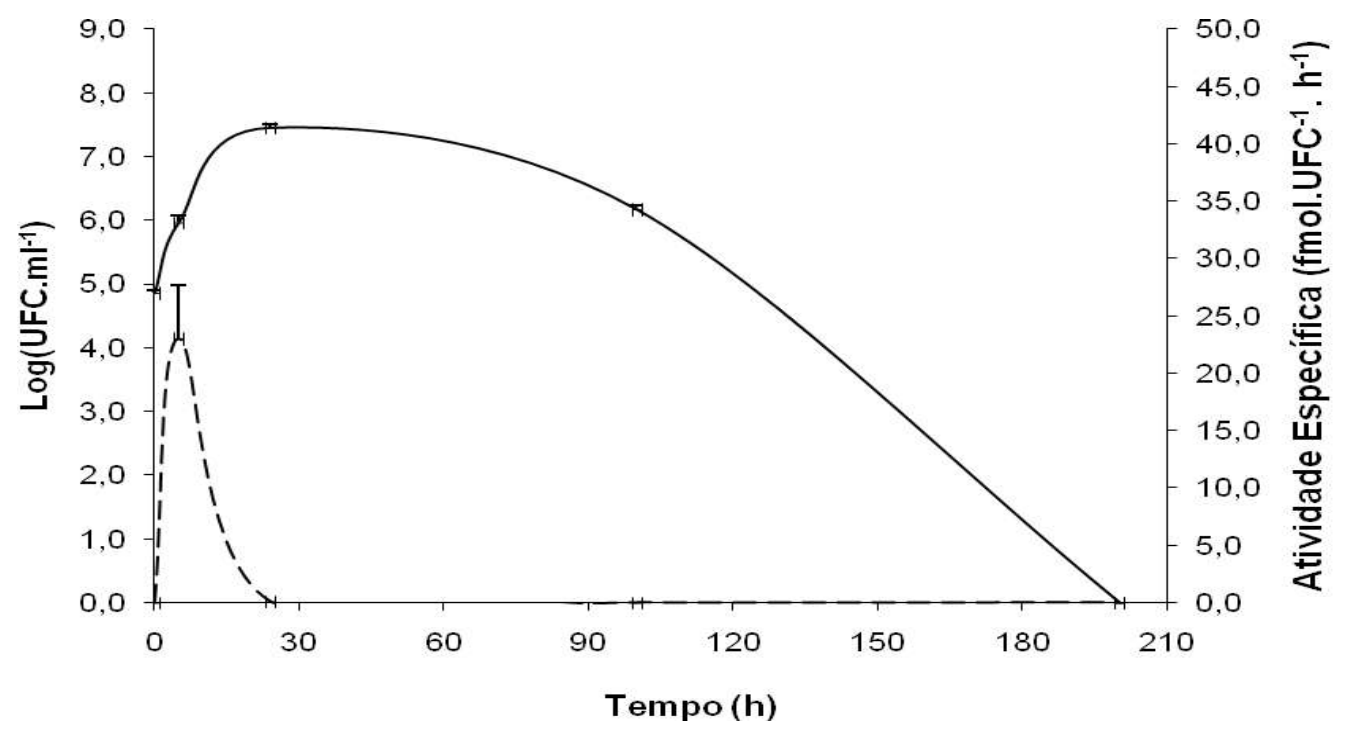

Figura 62 - Crescimento medido pelo Log (UFC) (-) e atividade específica (- - -) da enzima nitrogenase de Acinetobacter sp. (ICB117) em função do tempo em meio MMS. 
A atividade específica da nitrogenase apresentou valores de 23,02 fmol.UFC ${ }^{-1} \cdot h^{-1}$ durante a fase exponencial (cinco horas) diminuindo para 0,10 fmol.UFC${ }^{1} \cdot \mathrm{h}^{-1}$ com $24 \mathrm{~h}$. Não houve atividade após esse período (Figura 62).

Acinetobacter sp. (ICB117) liberou todos os compostos estudados no presente trabalho. Quatro aminoácidos diferentes foram excretados: Ala, Asp, Trp e Val. Sua detecção ocorreu apenas após $200 \mathrm{~h}$ e suas concentrações foram, respectivamente, $0,02,0,06,0,01$ e $0,04 \mu \mathrm{g} \cdot \mathrm{ml}^{-1}$ (Figura 63).

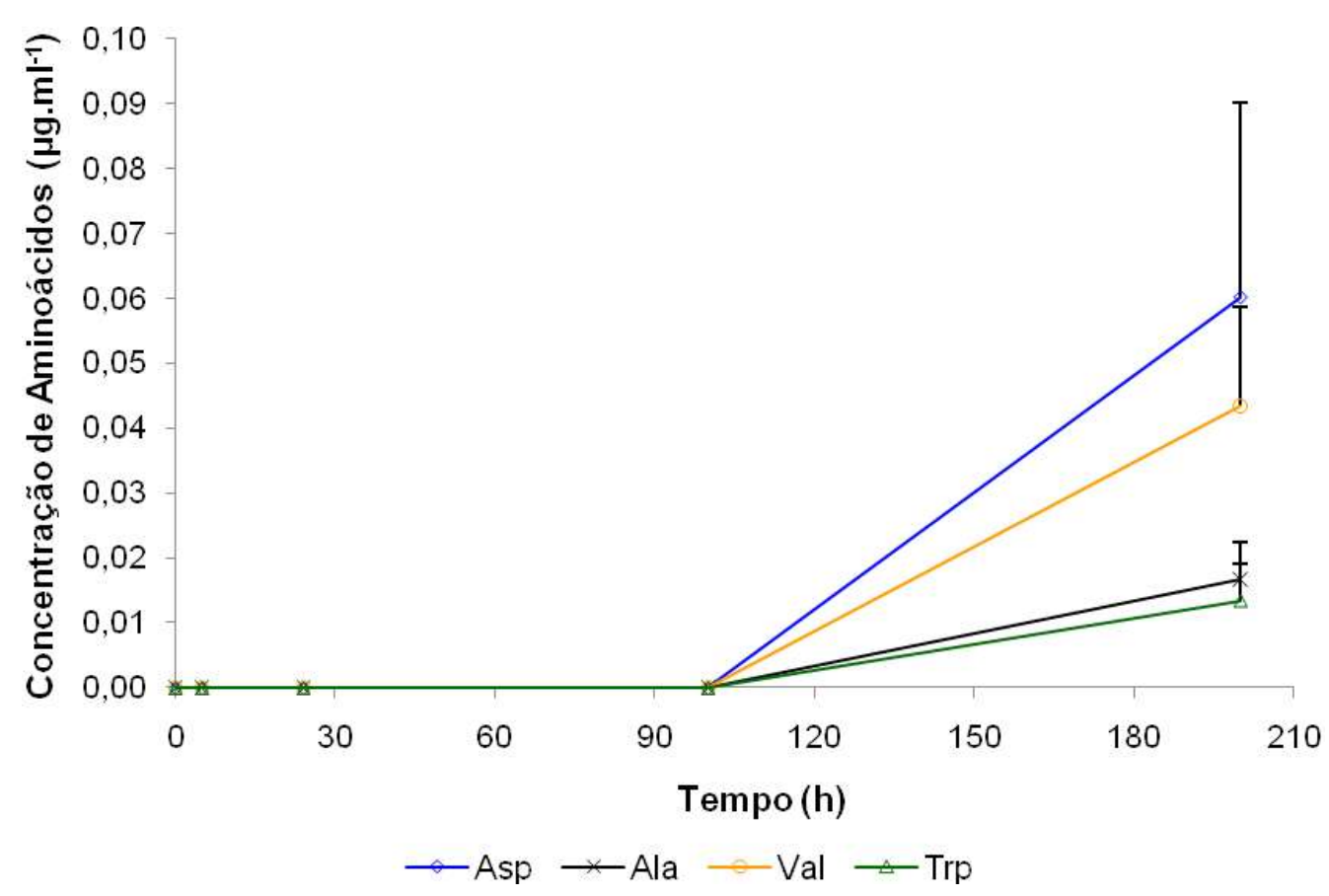

Figura 63 - Concentração de aminoácidos livres no meio ao longo do tempo em culturas de Acinetobacter sp. (ICB117) em meio MMS.

A única poliamina excretada por ICB117 foi a Put. Sua liberação ocorreu durante a fase exponencial atingindo concentrações de aproximadamente $0,6 \mu \mathrm{g} \cdot \mathrm{ml}^{-1}$. Com $100 \mathrm{~h}$ houve um aumento para $0,76 \mu \mathrm{g} \cdot \mathrm{ml}^{-1}$. Após $200 \mathrm{~h}$ essa substância não foi detectada (Figura 64). 


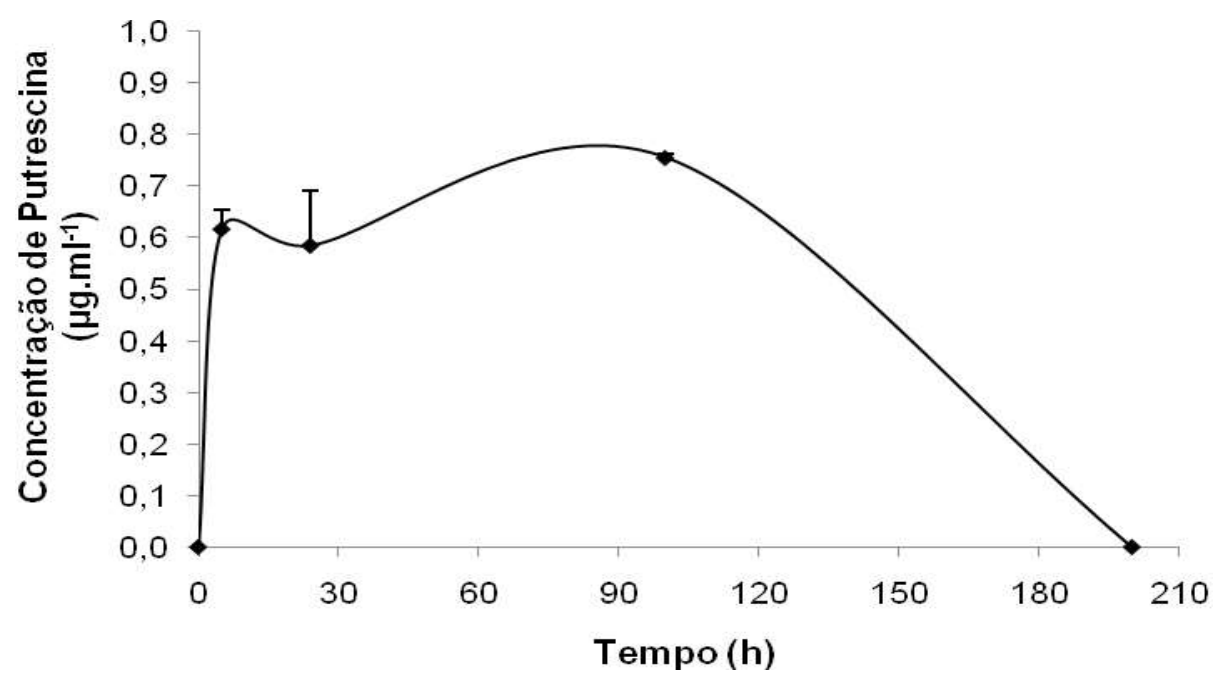

Figura 64 - Concentração da poliamina putrescina livre no meio ao longo do tempo em culturas de Acinetobacter sp. (ICB117) em meio MMS (一).

Com cinco horas de crescimento foi possível detectar a liberação de AlA pela linhagem ICB117 em quantidade que aumentou até 100h atingindo a 6,40 $\mu \mathrm{g} \cdot \mathrm{ml}^{-1}$. Com 200h a concentração média do fitormônio chegou a $7,61 \mu \mathrm{g} \cdot \mathrm{ml}^{-1}$ mas este aumento não foi significativo (Figura 65).

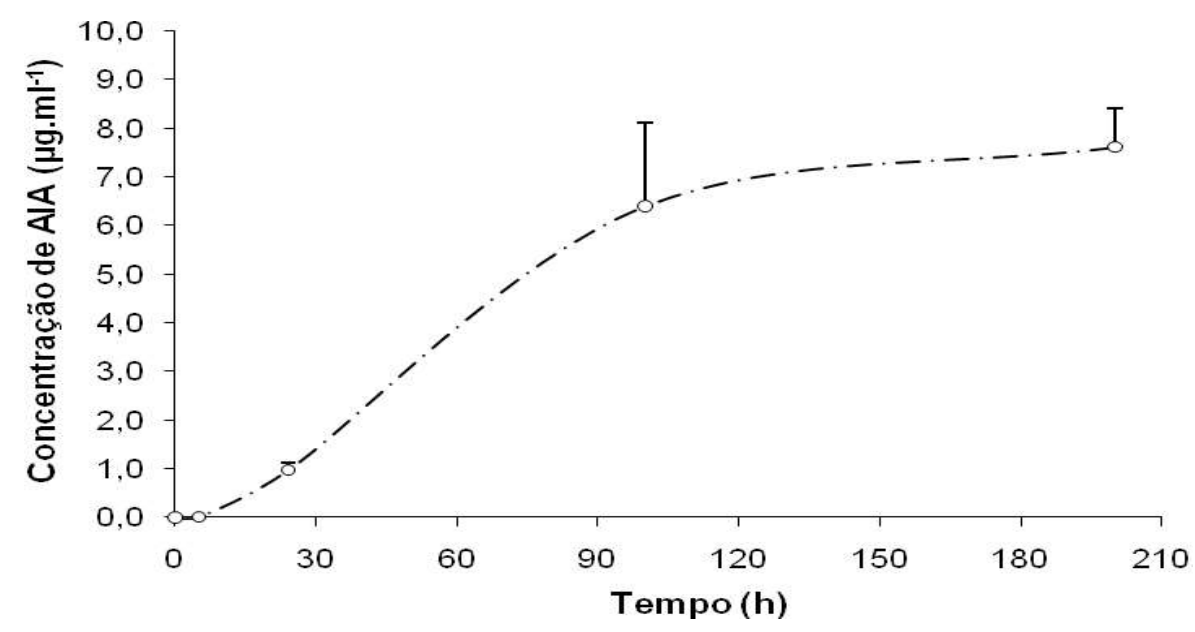

Figura 65 - Concentração de AIA livre detectada em meio MMS em função do tempo em culturas de Acinetobacter sp. ICB117 ( - - ). 
ICB117 produziu etileno em concentrações que aumentaram entre 144 e $240 \mathrm{~h}$. No primeiro ponto as concentrações do fitormônio eram de $2,87 \pm 0,16 \mathrm{nmol}^{\mathrm{ml}}{ }^{-1}$, no segundo esses valores chegaram a 4,64 $\pm 0,09$ nmol. $\mathrm{ml}^{-1}$.

\section{e) Pseudomonas}

As duas linhagens de Pseudomonas sp. estudadas mostraram-se diferentes entre si. ICB371 não foi capaz de crescer em meio MMS. Após a inoculação de cerca de $1.10^{5}$ células, a população diminuiu a $2,7.10^{3}$ UFC.ml-1 ao longo de $200 \mathrm{~h}$ (Figura 66). Não foram detectados aminoácidos, poliaminas, AIA ou etileno em culturas dessa bactéria.

Diferentemente, a linhagem ICB383 cresceu nas primeiras $24 \mathrm{~h}$ de $4,71.10^{5}$ UFC. $\mathrm{ml}^{-1} 1.10^{7}$ UFC. $\mathrm{ml}^{-1}$. Seguiu-se ligeira queda da população com estabilização em 1,5.10 ${ }^{6}$ UFC. $\mathrm{ml}^{-1}$ (Figura 67). ICB383 também não reduziu acetileno.

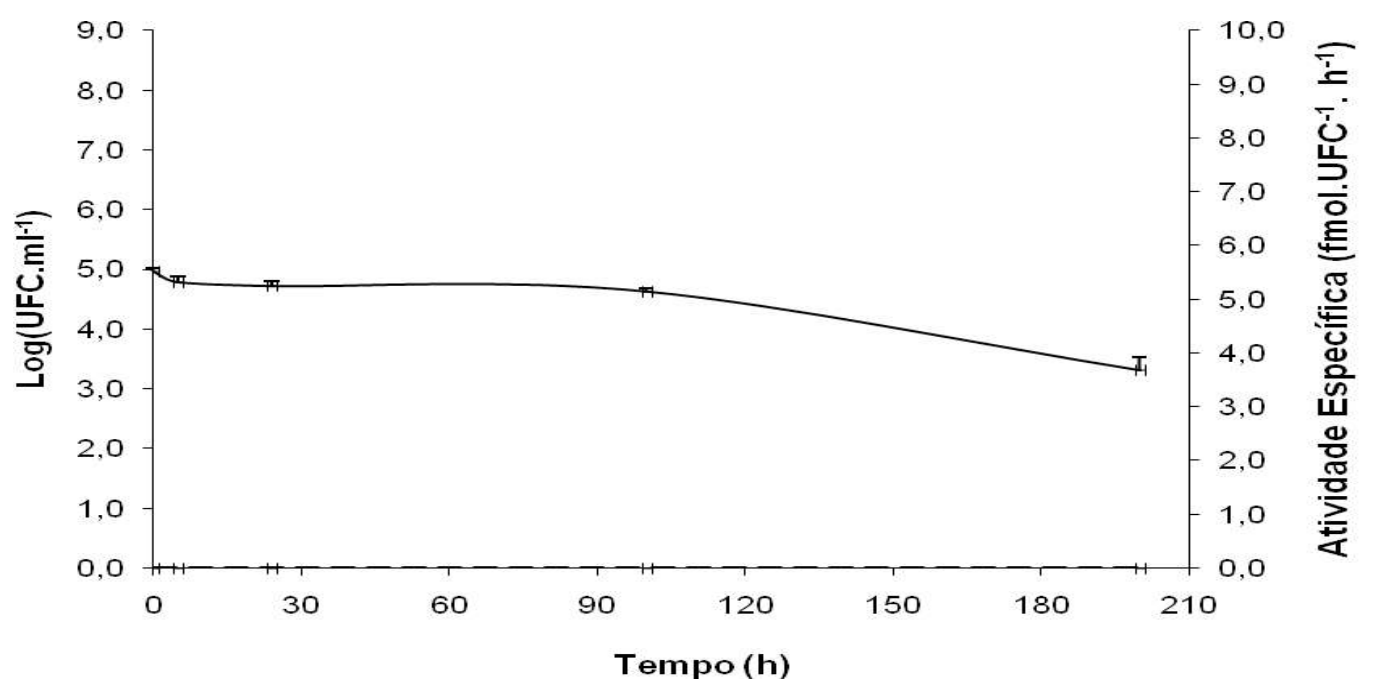

Figura 66 - Crescimento medido pelo Log (UFC) (-) e atividade específica (- - -) da enzima nitrogenase de Pseudomonas sp. (ICB371) em função do tempo em meio MMS. 


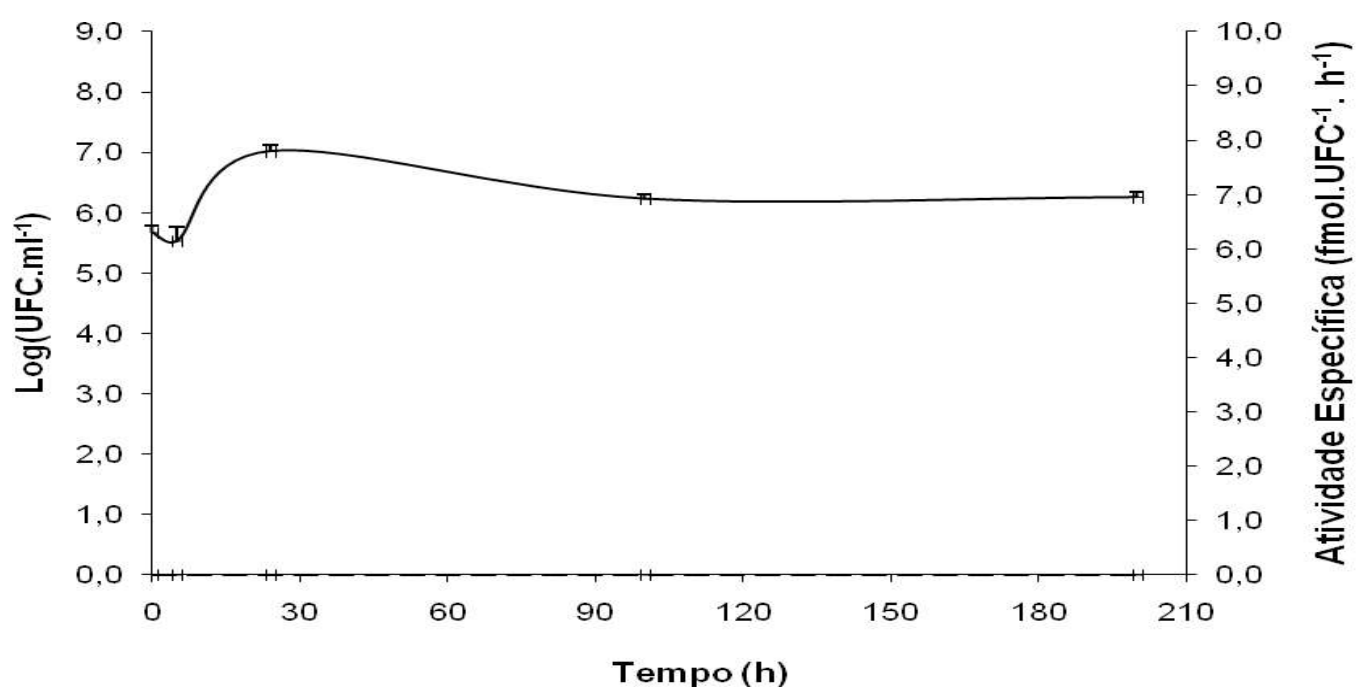

Figura 67 - Crescimento medido pelo Log (UFC) (-) e atividade específica (- - -) da enzima nitrogenase de Pseudomonas sp. (ICB383) em função do tempo em meio MMS.

Das quatro substâncias estudadas, relacionadas ao crescimento vegetal, ICB383 liberou poliaminas e AIA ao meio. A poliamina liberada foi a putrescina (Figura 68). A excreção ocorreu entre cinco e 24h, com $0,46 \mu g \cdot \mathrm{ml}^{-1}$. Com 100 e $200 \mathrm{~h}$ os valores detectados não apresentaram alteração significativa.

A liberação de AIA pela linhagem ICB383 foi detectada a partir de cinco horas de cultura e aumentou ao longo de todo o experimento. Seus valores subiram de 0,03 $\mu \mathrm{g} \cdot \mathrm{ml}^{-1}$ na fase exponencial para $1,69 \mu \mathrm{g} \cdot \mathrm{ml}^{-1} \mathrm{com} 200 \mathrm{~h}$ (Figura 69).

ICB383 não liberou aminoácidos e etileno. 


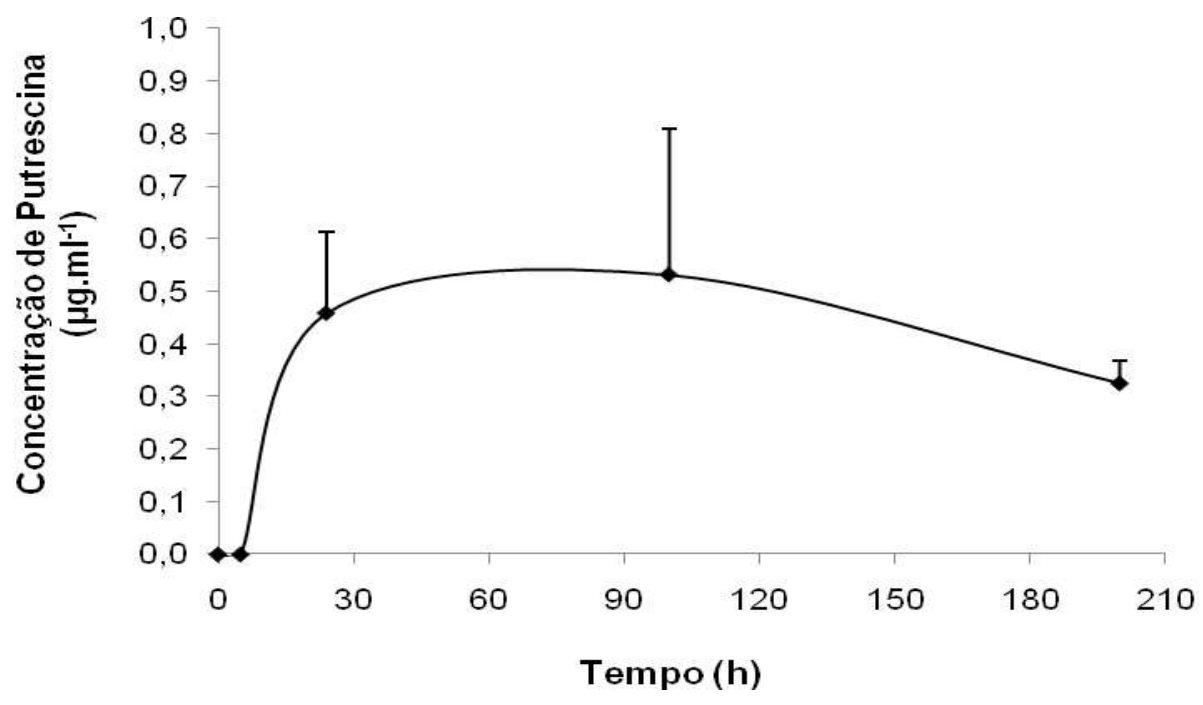

Figura 68 - Concentração da poliamina putrescina livre no meio ao longo do tempo em culturas de Pseudomonas sp. (ICB383) em meio MMS (-).

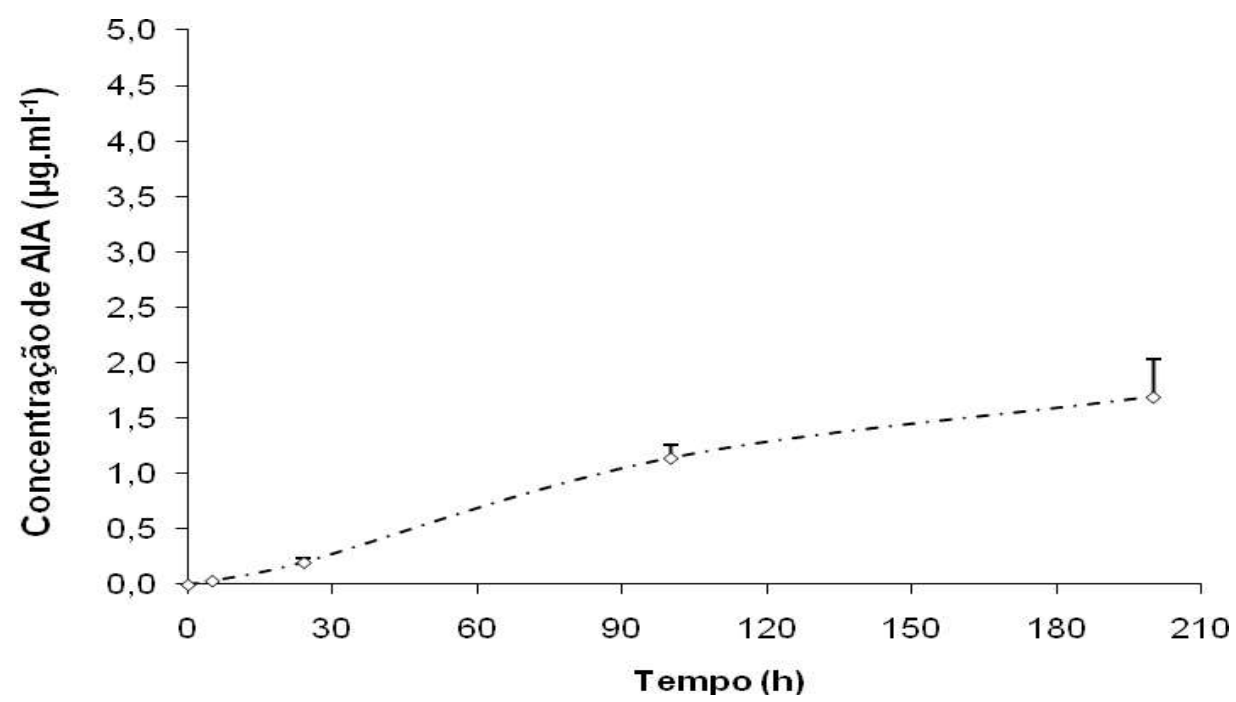

Figura 69 - Concentração de AIA livre detectada em meio MMS, em função do tempo, em culturas de Pseudomonas sp. ICB383 ( - ) - .

\section{f) Chryseobacterium}

Uma única linhagem de Chryseobacterium sp. foi aqui estudada. A população de ICB379, aumentou até o valor de 3,0.10 $\mathrm{UFC} \cdot \mathrm{ml}^{-1}$. A partir desse ponto, houve uma 
diminuição gradual do número de células na cultura atingindo $4,5.10^{5}$ UFC.ml-1. A nitrogenase esteve ativa apenas na fase exponencial com valores de atividade específica de 13,13 fmol.UFC f $^{-1} \cdot \mathrm{h}^{-1}$ em cinco horas de crescimento (Figura 70 ).

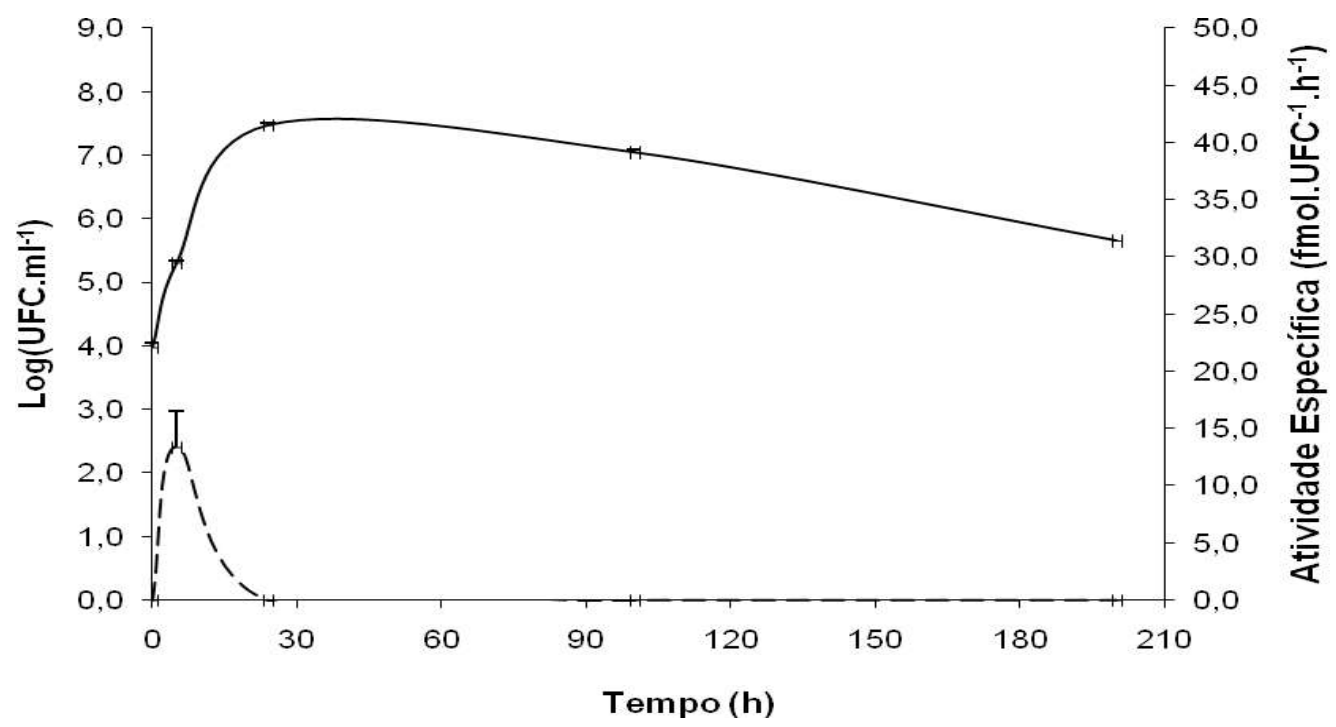

Figura 70 - Crescimento medido pelo Log (UFC) (-) e atividade específica (- - -) da enzima nitrogenase de Chryseobacterium sp. (ICB379) em função do tempo em meio MMS.

A Put, foi detectada apenas com $100 \mathrm{~h}$ de crescimento. $\left(0,90 \mu \mathrm{g} \cdot \mathrm{ml}^{-1}\right)$ (Figura 71).

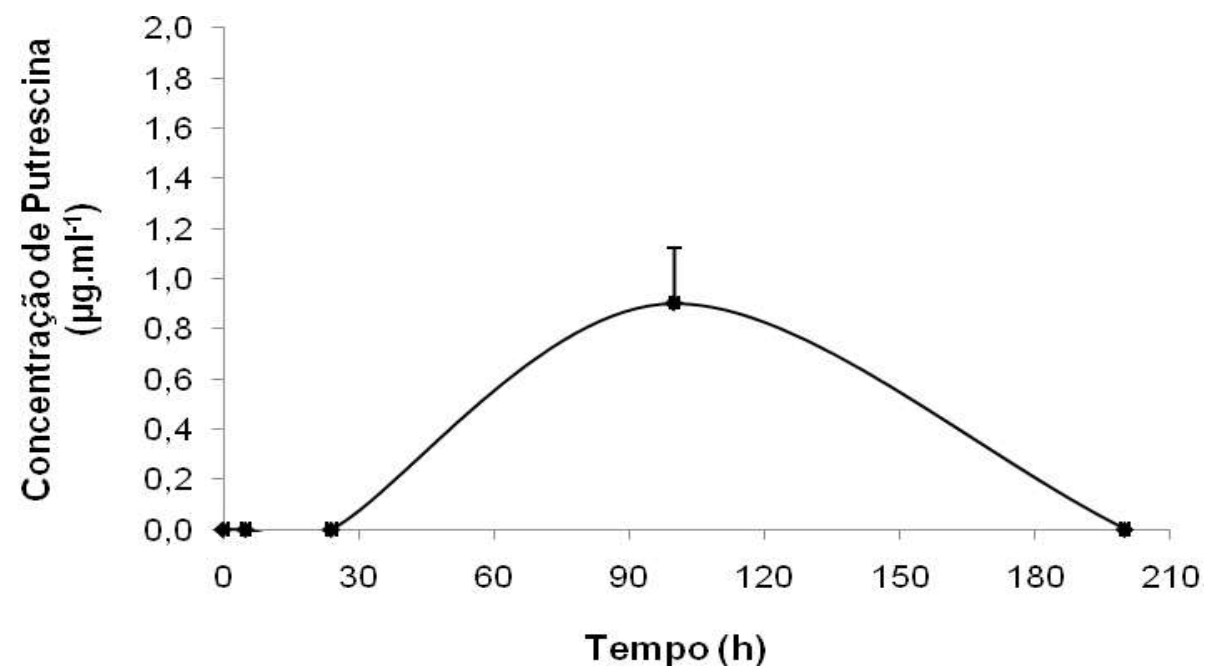

Figura 71 - Concentração da poliamina putrescina livre no meio ao longo do tempo em culturas de Chryseobacterium sp. (ICB379) em meio MMS ) (一). 
Não foram detectadas liberações de aminoácidos, AIA e etileno por Chryseobacterium sp. (ICB379).

\section{g) Rhizobium}

A linhagem ICB386 pertencente ao gênero Rhizobium apresentou alta velocidade de crescimento, elevando seu número de células de cultura de $1.10^{5}$ UFC. $\mathrm{ml}^{-1}$ para $3.10^{6} \mathrm{UFC} \cdot \mathrm{ml}^{-1} \mathrm{em}$ cinco horas; $1,13.10^{8} \mathrm{UFC} \cdot \mathrm{ml}^{-1}$ foi a maior população encontrada. Com 200h a quantidade de células havia declinado para $1,9.10^{6} \mathrm{UFC} \cdot \mathrm{ml}^{-1}$. A atividade da nitrogenase foi detectada apenas nas primeiras cinco horas de experimento. Os valores médios de atividade específica nesse tempo foram de 4,95 fmol.UFC ${ }^{-1} \cdot h^{-1}$ (Figura 72 ).

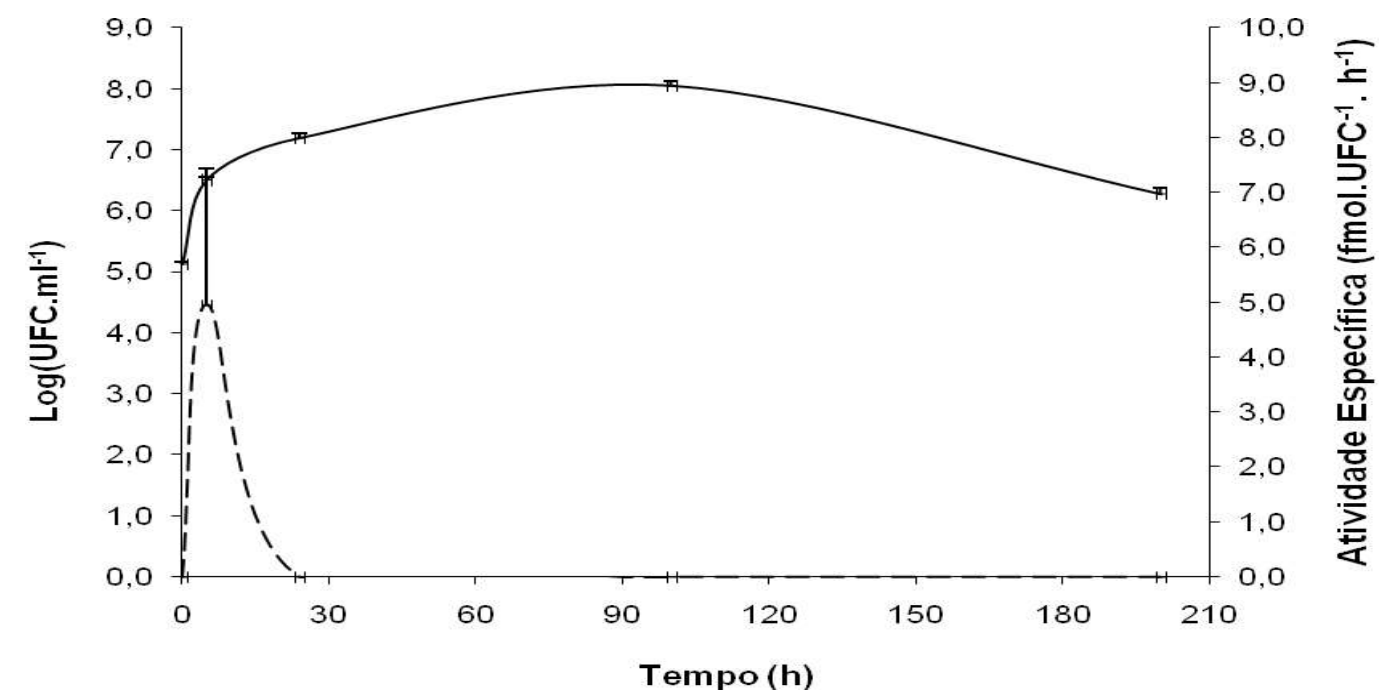

Figura 72 - Crescimento medido pelo Log (UFC) (-) e atividade específica (- - -) da enzima nitrogenase de Rhizobium sp. (ICB386) em função do tempo em meio MMS.

ICB386 liberou Put, detectada após 100h de crescimento em concentrações de $0,26 \mu \mathrm{g} \cdot \mathrm{ml}^{-1}$, tendo, então estabilizado (Figura 73). 
Esta linhagem de Rhizobium liberou AIA durante todo o experimento. Com cinco horas foi observada pequena quantidade do hormônio no meio $\left(0,01 \mu \mathrm{g} \cdot \mathrm{ml}^{-1}\right)$. A partir dai foi verificado um aumento linear da concentração de AIA até 200h quando a concentração do fitormônio atingiu 8,53 $\mu \mathrm{g} \cdot \mathrm{ml}^{-1}$ (Figura 74).

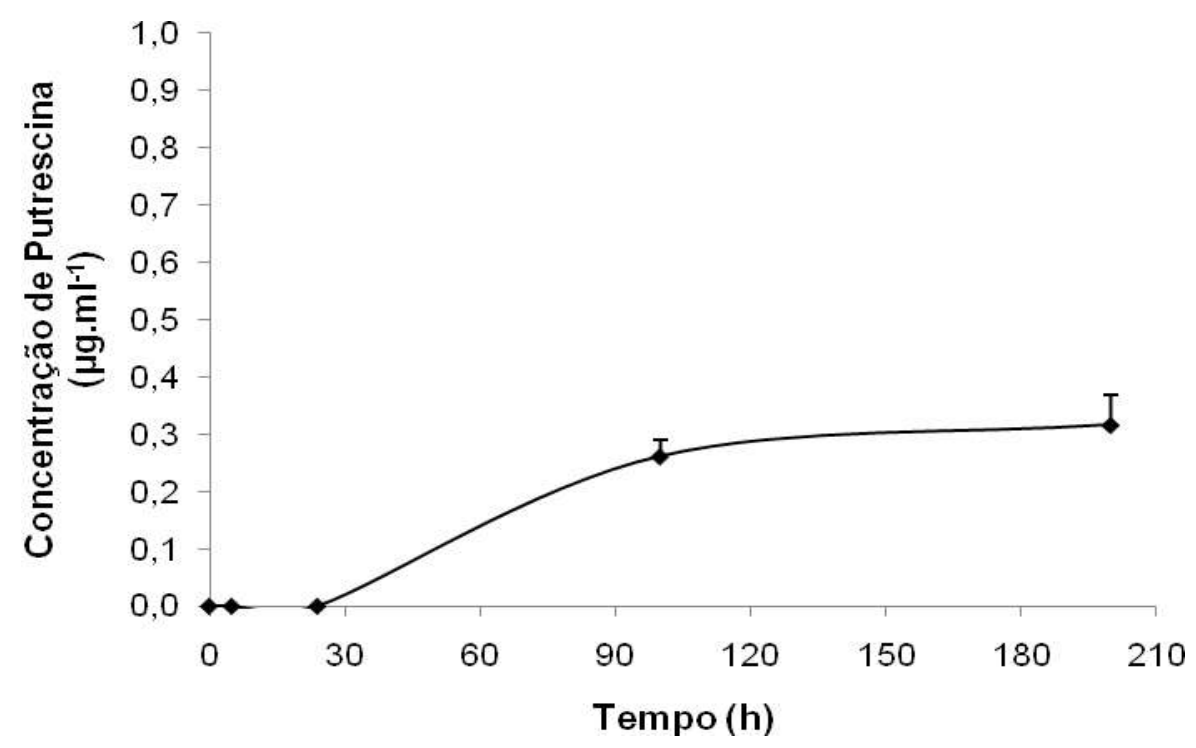

Figura 73 - Concentração da poliamina putrescina livre no meio ao longo do tempo em culturas de Rhizobium sp. (ICB386) em meio MMS (一).

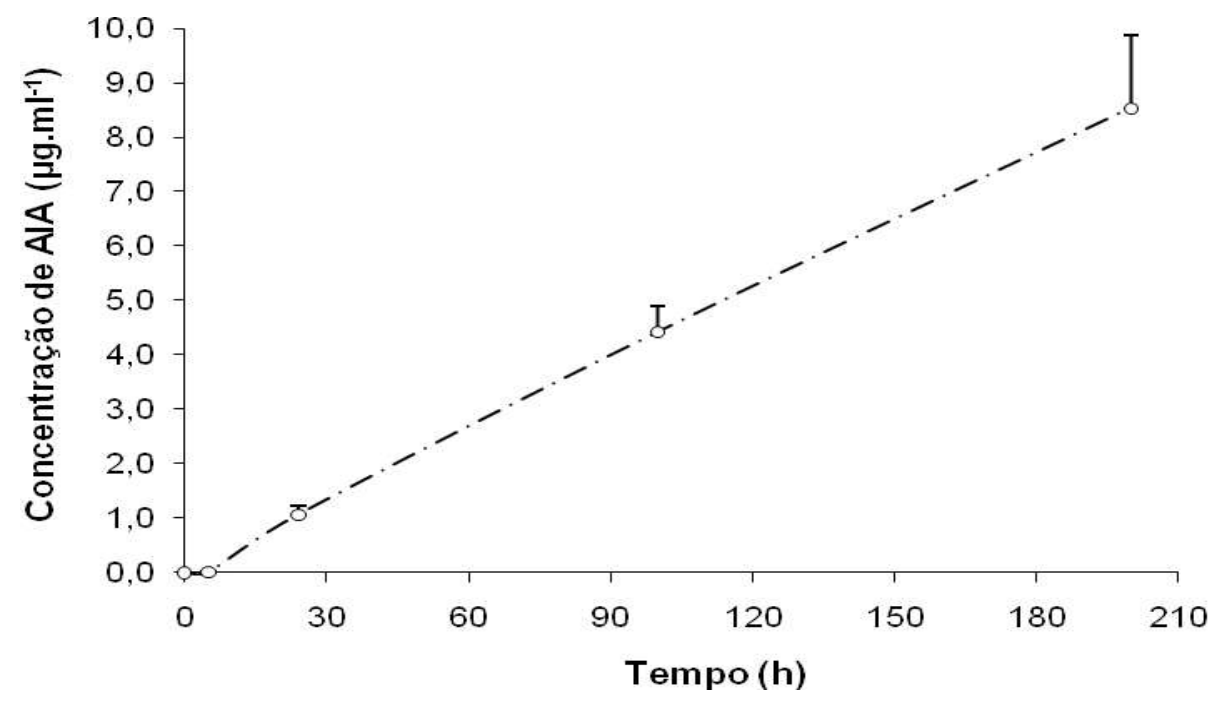

Figura 74 - Concentração de AIA livre detectada em meio MMS em função do tempo em culturas de Rhizobium sp. ICB386 $(-\cdot)$ 
O Isolado ICB386 liberou etileno em concentrações crescentes, de 3,97 $\pm 0,17$ nmol.ml ${ }^{-1}$ em 144 para $5,63 \pm 0,07 \mathrm{nmol} \mathrm{ml}^{-1}$ após $240 \mathrm{~h}$ de crescimento.

\section{h) Grimontella}

A linhagen de Grimontella sp. (ICB397) apresentou crescimento populacional atingindo aproximadamente $1,5.10^{7} \mathrm{UFC} \cdot \mathrm{ml}^{-1}$. Assim se manteve até $100 \mathrm{~h}$ e caiu para

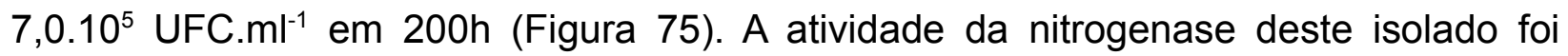
detectada apenas na fase exponencial. Os valores obtidos foram altos, com média de 122,95 fmol.UFC ${ }^{-1} \cdot \mathrm{h}^{-1}$ (Figura 75). Esta linhagem não foi capaz de liberar aminoácidos ou poliaminas.

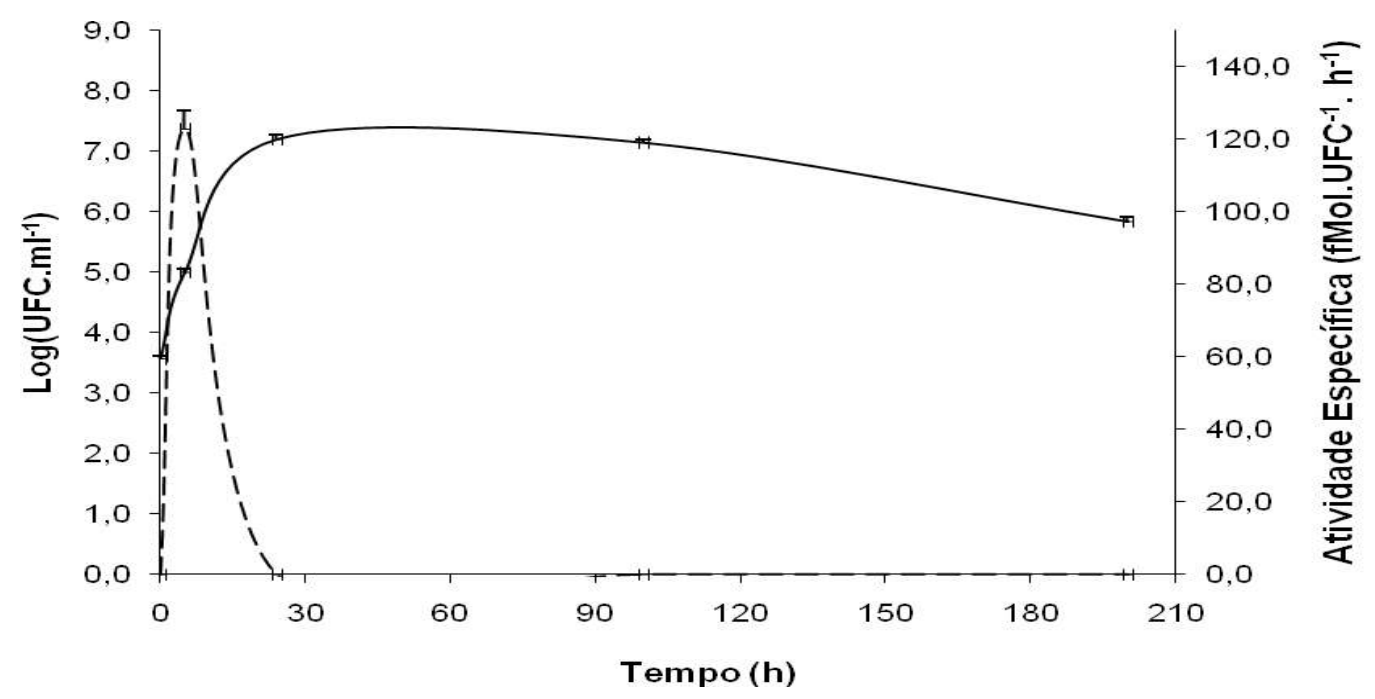

Figura 75 - Crescimento medido pelo Log (UFC) (-) e atividade específica (- - -) da enzima nitrogenase de Grimontella sp. (ICB397) em função do tempo em meio MMS.

Foram detectadas concentrações de até $2,84 \mu \mathrm{g} \cdot \mathrm{ml}^{-1}$ de AIA na cultura da linhagem ICB397. A excreção iniciou-se durante a fase exponencial, aumentou até 100h e se manteve constante (Figura 76). 


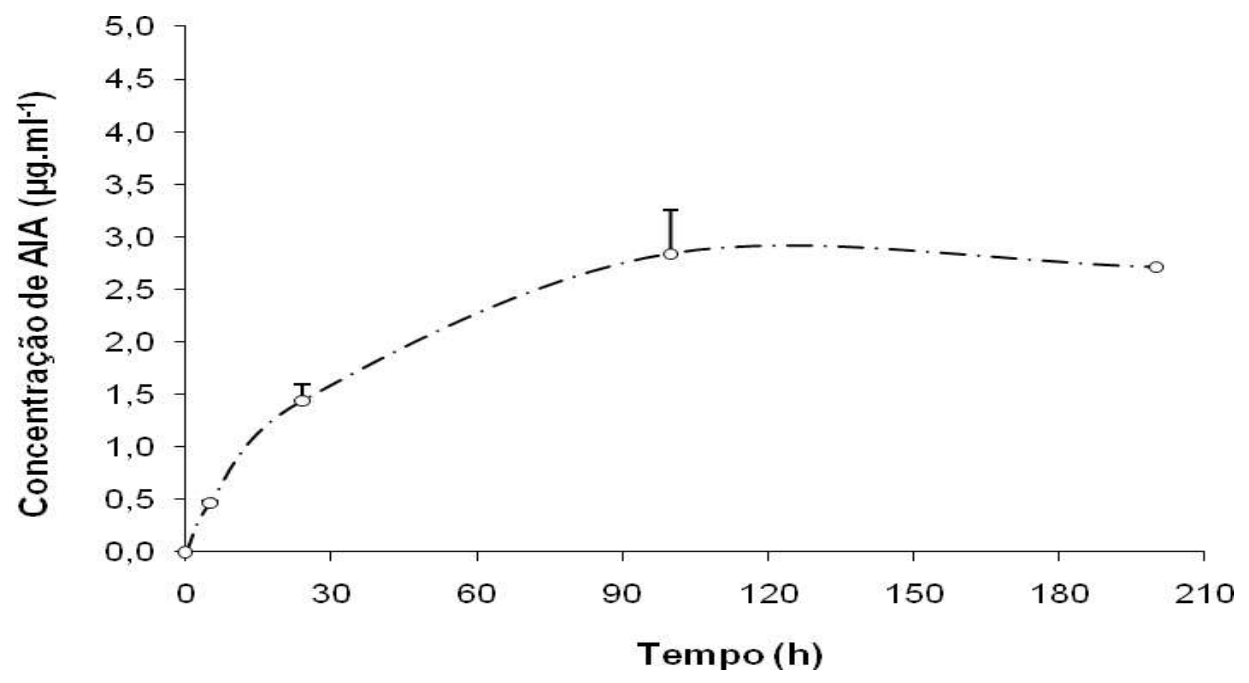

Figura 76 - Concentração de AIA livre detectada em meio MMS em função do tempo em culturas de Grimontella sp. ICB397 ( - - ):

ICB397 também foi capaz de produzir etileno. Com 144h foram detectadas concentrações de 2,05 \pm 0,06 nmol.ml ${ }^{-1}$ nas culturas. Esse valor aumentou para 2,91 \pm $0,24 \mathrm{nmol}^{\mathrm{ml}} \mathrm{-}^{-1}$ após $240 \mathrm{~h}$.

\section{i) Erwinia}

A única linhagem de Erwinia sp. estudada, ICB409, teve crescimento e atividade específica da nitrogenase baixos. Sua população aumentou pouco: de 1,2.10 para $2,12 \cdot 10^{6}$ UFC. $\mathrm{ml}^{-1}$. Com $24 \mathrm{~h}$ houve uma diminuição acentuada da quantidade de UFC, seguida de leve declínio (Figura. 77). A redução de acetileno ocorreu apenas nas primeiras cinco horas do experimento. Foi detectada uma atividade específica da nitrogenase baixa: $2,23 \mathrm{fmol} . \mathrm{UFC}^{-1} \cdot \mathrm{h}^{-1}$ (Figura 77 ). 


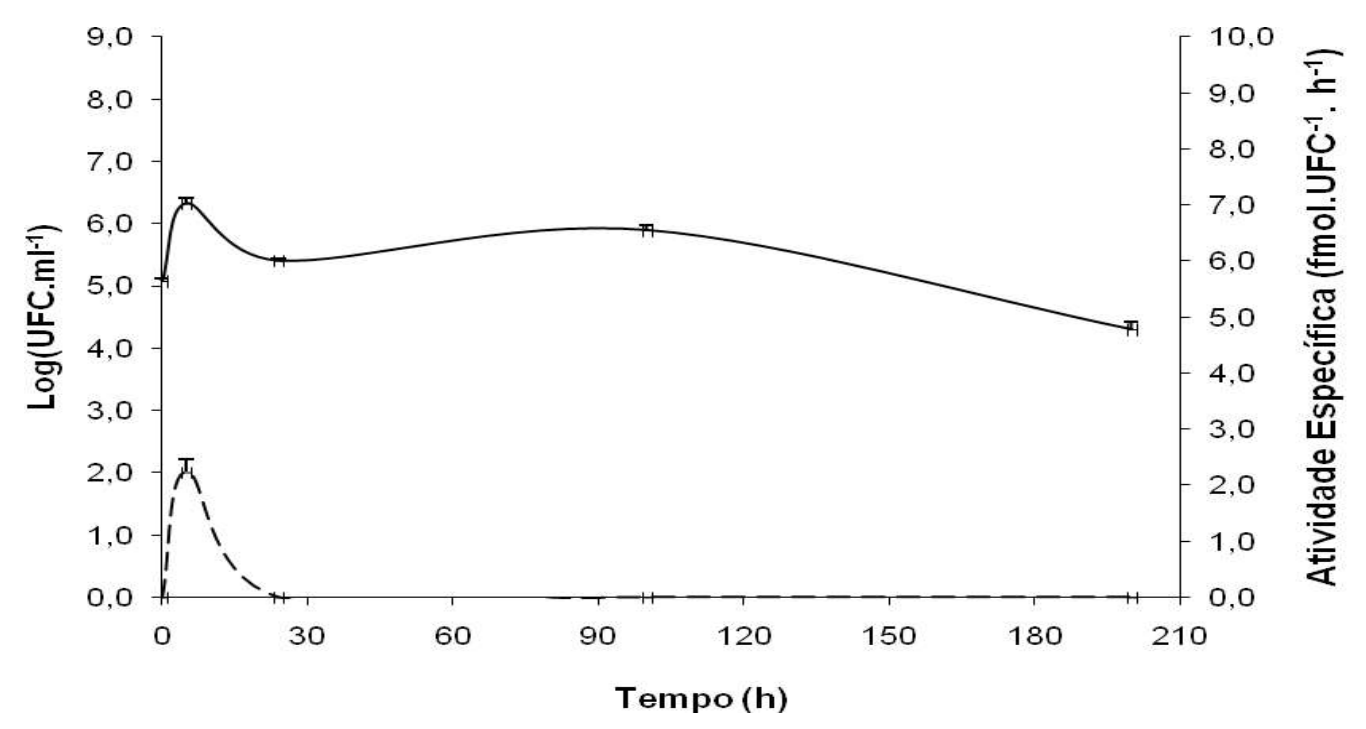

Figura 77 - Crescimento medido pelo Log (UFC) (-) e atividade específica (- - -) da enzima nitrogenase de Erwinia sp. (ICB409) em função do tempo em meio MMS.

A presença de AIA no meio de cultura da linhagem ICB409 foi detectada a partir de cinco horas de crescimento. Houve acúmulo dessa substância até 100h de cultura, quando a concentração atingiu seu máximo valor de 2,93 $\mu \mathrm{g} \cdot \mathrm{ml}^{-1}$, detectando-se, a seguir, uma diminuição da quantidade de AIA livre no meio para 1,24 $\mu \mathrm{g} \cdot \mathrm{ml}^{-1}$ (Figura 78).

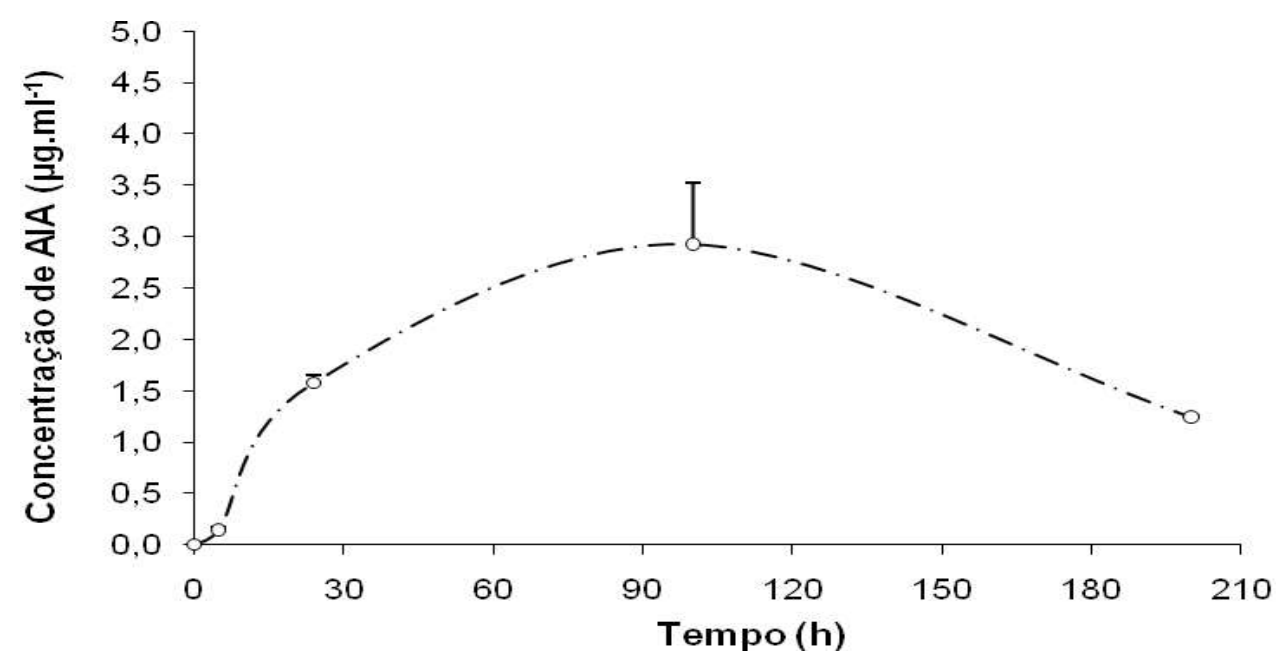

Figura 78 - Concentração de AIA livre detectada em meio MMS em função do tempo em culturas de Erwinia sp. ICB409 ( - - ) 
Não houve liberação de aminoácidos, poliaminas e etileno por ICB409.

\section{j) Gluconoacetobacter}

A curva de crescimento de Gluconoacetbacter sp., ICB557 mostrou que essa bactéria cresceu até 6,7.10 UFC.ml-1. Este valor não se alterou significativamente após 100 h de cultura. Com 200h, no entanto, não foram mais encontradas células viáveis (Figura 79). A atividade da nitrogenase foi detectada após cinco e $24 \mathrm{~h}$ com valores de 16,21 e 0,12 fmol.UFC ${ }^{-1} \cdot h^{-1}$. Não houve redução de acetileno após esse período (Figura 79).

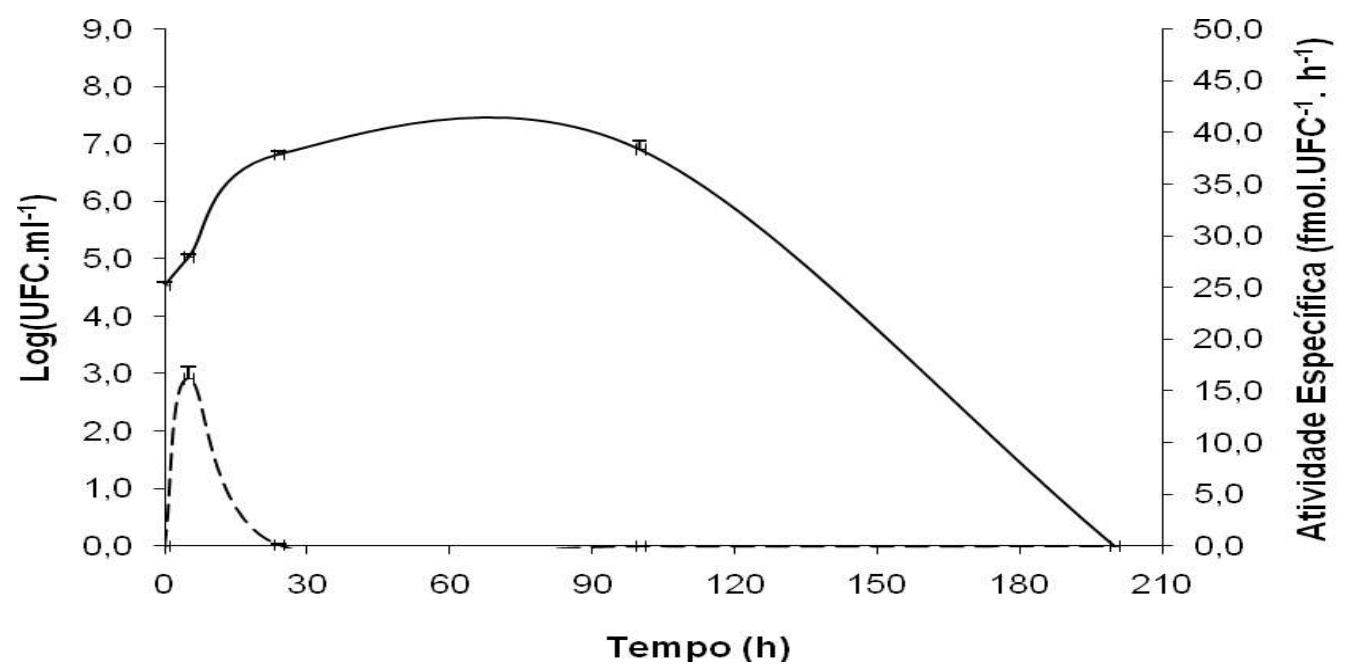

Figura 79 - Crescimento medido pelo Log (UFC) (-) e atividade específica (- - -) da enzima nitrogenase de Gluconoacetobacter sp. (ICB557) em função do tempo em meio MMS.

ICB557 foi capaz de liberar AIA. As concentrações dessa substância aumentaram até o fim do experimento com um período de estabilização compreendido entre 24 e 100h. A maior concentração foi de 1,66 $\mu \mathrm{g} \cdot \mathrm{ml}^{-1}$ (Figura 80). 
A liberação de etileno por ICB577 foi detectada após 144 e $240 \mathrm{~h}$ de cultivo bacteriano. As concentração obtidas aumentaram de $0,99 \pm 0,22 \mathrm{fmol}^{\mathrm{ml}}{ }^{-1}$ para 1,47 \pm $0,13 \mathrm{fmol} \cdot \mathrm{ml}^{-1}$, respectivamente.

Gluconacetobacter sp. (ICB557) não foi capaz de liberar aminoácidos ou poliaminas.

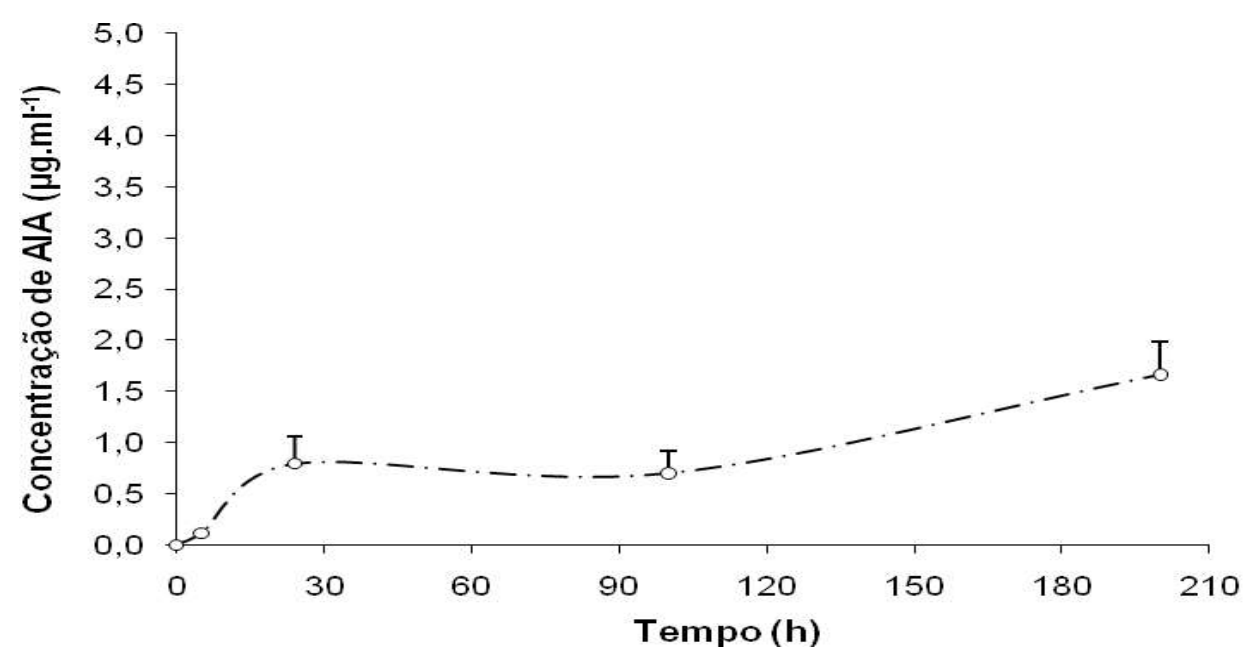

Figura 80 - Concentração de AIA livre detectada em meio MMS em função do tempo em culturas de Gluconoacetobacter sp. ICB409 ( - $\rightarrow$ ·

\subsection{INFLUÊNCIA DA ADUBAÇÃO NAS CARACTERÍSTICAS FISIOLÓGICAS DOS} ISOLADOS

Não houve diferença significativa no crescimento e atividade específica dos isolados de cana-de-açúcar submetidos aos diferentes tratamentos (Figuras 81 e 82). No entanto, foi possível observar que a maioria das bactérias isoladas de cana-deaçúcar adubada organicamente manteve a nitrogenase ativa por pelo menos $100 \mathrm{~h}$, enquanto a maior parte dos isolados de cana-de-açúcar adubada convencionalmente 
ou não adubada perdeu a atividade da enzima mais cedo (Tabela 7).

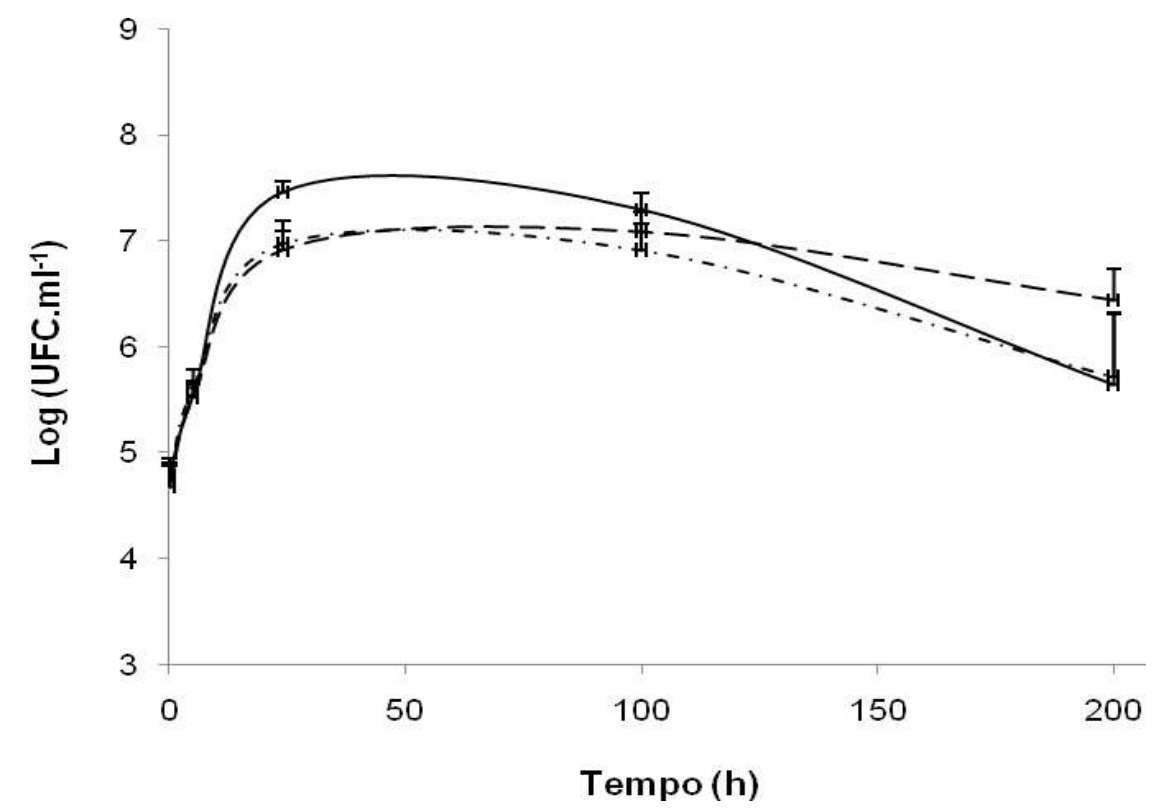

Figura 81 - Crescimento médio, medido pelo Log (UFC.ml-1), e respectivo erro padrão, ao longo do tempo, em culturas de bactérias isoladas de cana-de-açúcar adubada organicamente (-), convencionalmente (- - ) ou não fertilizada (- - -)

Tabela 7 - Porcentagem de bactérias isoladas de cana-de-açúcar, submetida aos diferentes tratamentos, que apresentaram a nitrogenase ativa em cada um dos pontos da curva de crescimento. Letras diferentes indicam diferença significativa entre os tratamentos.

\begin{tabular}{ccccc}
\hline Tratamento & $5 \mathrm{~h} \mathrm{( \% )}$ & $24 \mathrm{~h}(\%)$ & $100 \mathrm{~h} \mathrm{( \% )}$ & $200 \mathrm{~h}(\%)$ \\
\hline Orgânico & $91,7(\mathrm{a})$ & $83,3(\mathrm{a})$ & $58,3(\mathrm{a})$ & $0,0(\mathrm{a})$ \\
Convencional & $83,3(\mathrm{a})$ & $58,3(\mathrm{~b})$ & $25,0(\mathrm{~b})$ & $0,0(\mathrm{a})$ \\
Controle & $100,0(\mathrm{a})$ & $33,3(\mathrm{~b})$ & $16,7(\mathrm{~b})$ & $0,0(\mathrm{a})$ \\
\hline
\end{tabular}




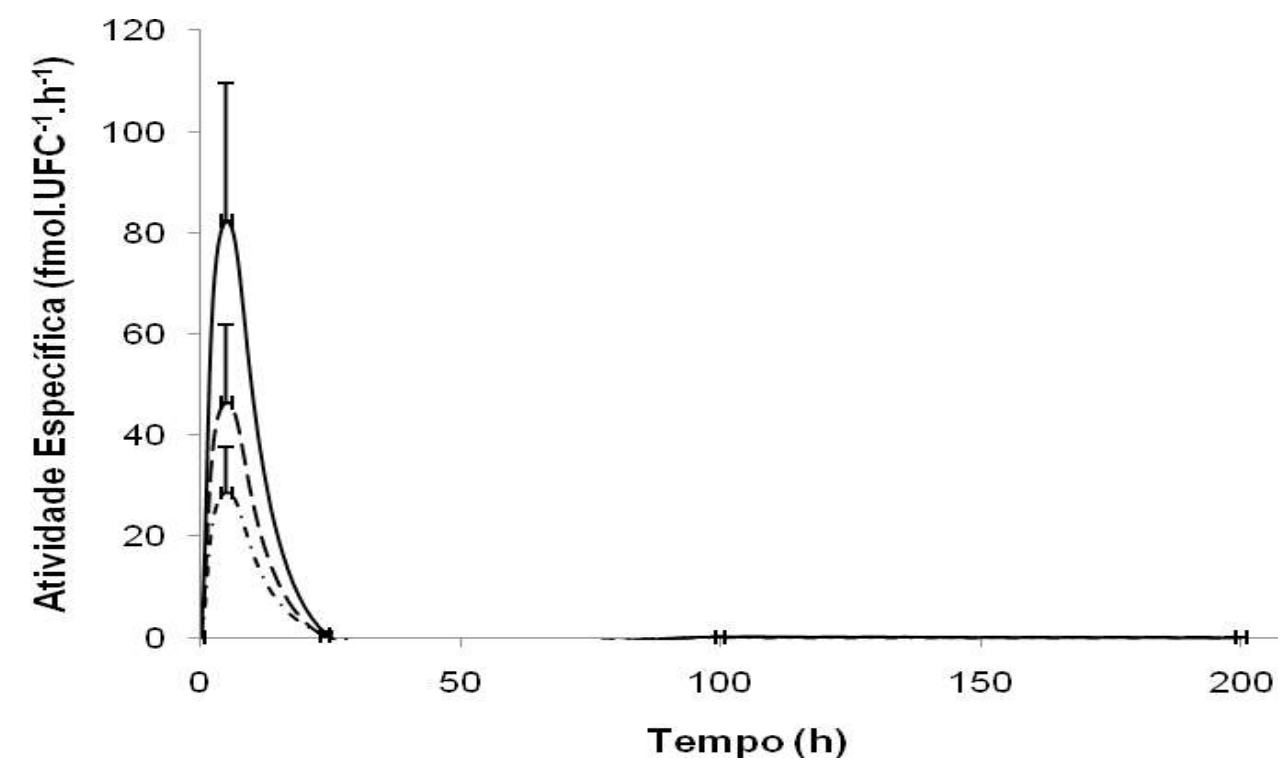

Figura 82 - Atividade específica média (levando-se em conta todos os isolados) da enzima nitrogenase e respectivo erro padrão, ao longo do tempo, em culturas de bactérias isoladas de cana-de-açúcar adubada organicamente (-), convencionalmente (- - ) ou controle (- - -).

A tabela 8 mostra que houve diferença significativa na proporção de linhagens capazes de liberar aminoácidos e etileno dependendo do tipo de tratamento aplicado à cana-de-açúcar de onde foram isolados. A cana-de-açúcar tratada organicamente possuía maior número de linhagens capazes de liberar aminoácidos que a cana-deaçúcar adubada convencionalmente. A cana-de-açúcar do grupo controle foi a que apresentou menor número de bactérias aptas a excretar aminoácidos. De maneira contrária, a proporção de bactérias capazes de liberar etileno foi maior na cana-deaçúcar não adubada que naquela submetida à adubação convencional. Nenhuma destas duas apresentou diferença significativa em relação ao número de isolados capazes de liberar etileno obtido de cana-de-açúcar tratada organicamente. 
Tabela 8 - Porcentagem de bactérias capazes de liberar SPCV em meio de cultura de acordo com o tratamento dado à cana-de-açúcar de onde foram isolados. Letras diferentes indicam diferença significativa entre os tratamentos pelo teste de comparação de proporções $(P=0,05)$.

\begin{tabular}{ccccc}
\hline Tratamento & Aminoácidos (\%) & Poliaminas (\%) & AIA (\%) & Etileno (\%) \\
\hline Orgânico & $75,0(\mathrm{a})$ & $33,3(\mathrm{a})$ & $100,0(\mathrm{a})$ & $83,3(\mathrm{ab})$ \\
Convencional & $33,3(\mathrm{~b})$ & $41,7(\mathrm{a})$ & $83,3(\mathrm{a})$ & $75,0(\mathrm{~b})$ \\
Controle & $8,3(\mathrm{c})$ & $16,7(\mathrm{a})$ & $91,7(\mathrm{a})$ & $100,0(\mathrm{a})$ \\
\hline
\end{tabular}

Houve diferença significativa na quantidade média de aminoácidos liberados por bactérias isoladas de cana-de-açúcar submetida aos diferentes tratamentos. Considerando a liberação ao longo do tempo (Figura 83), isolados de plantas adubadas organicamente liberaram maiores quantidades de aminoácidos que bactérias obtidas de cana-de-açúcar tratada convencionalmente ou controle após 200 h. Da mesma forma, quando são consideradas apenas as máximas concentrações de aminoácidos liberadas por cada bactéria, a excreção desses compostos por bactérias de cana adubada organicamente foi maior (Tabela 9).

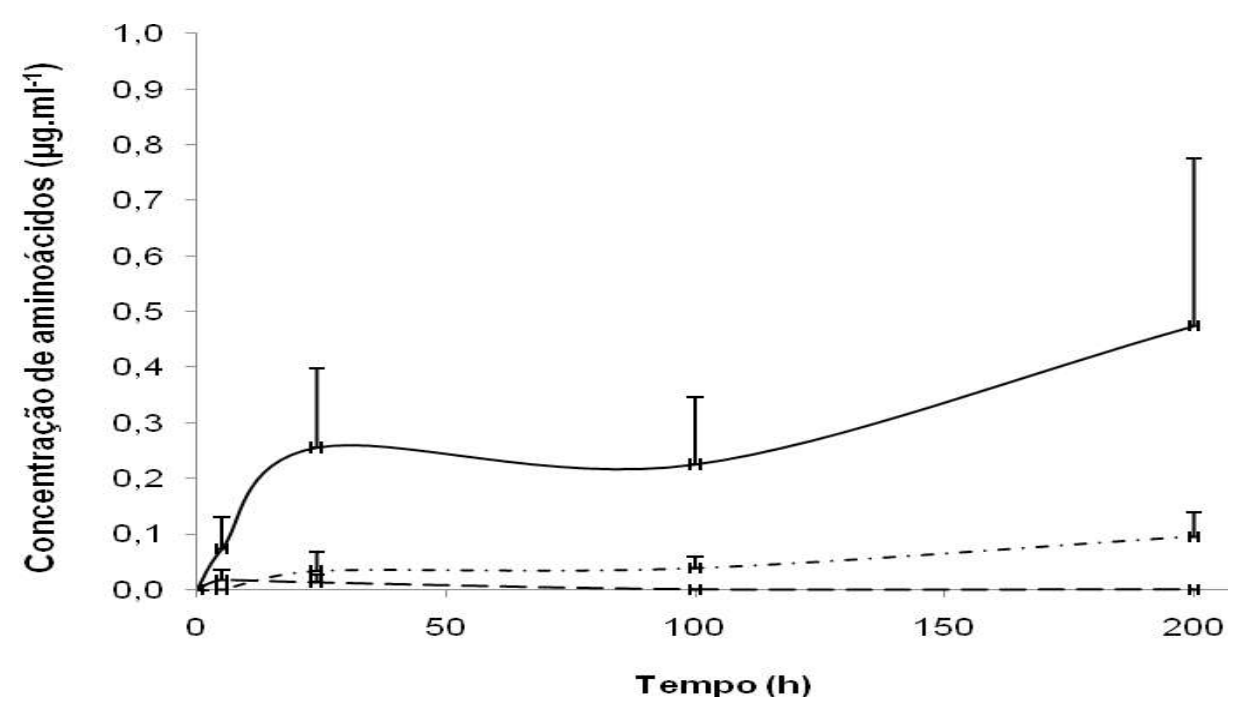

Figura 83 - Liberação média de aminoácidos (levando-se em conta todos os isolados) e respectivo erro padrão, ao longo do tempo, em culturas de bactérias isoladas de cana-de-açúcar adubada organicamente (-), convencionalmente ( - ) ou controle (- - -). 
Não houve diferença significativa nas quantidades de poliaminas e AIA liberadas por bactérias isoladas de cana-de-açúcar adubadas pelos diferentes métodos, tanto ao longo do tempo quanto levando em consideração apenas à máxima liberação de cada uma das substâncias (Figuras 84 e 85; Tabela 9).

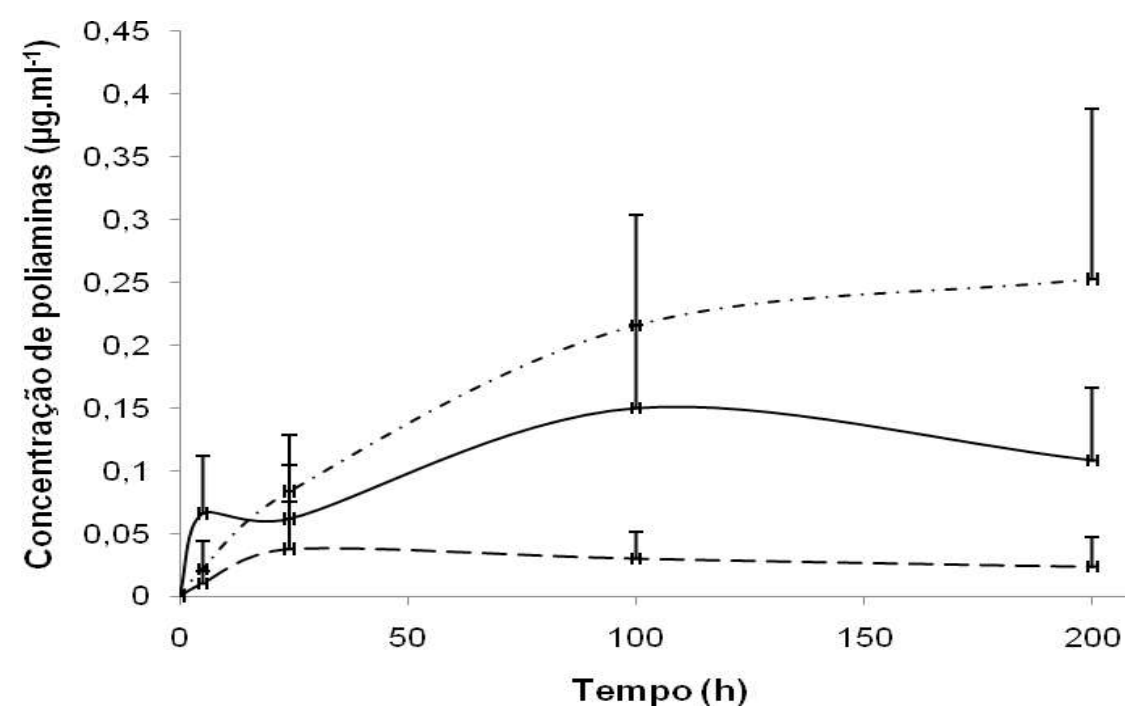

Figura 84 - Liberação média de poliaminas (levando-se em conta todos os isolados) e respectivo erro padrão, ao longo do tempo, em culturas de bactérias isoladas de cana-de-açúcar adubada organicamente (-), convencionalmente (- $\rightarrow$ ou controle (- - -).

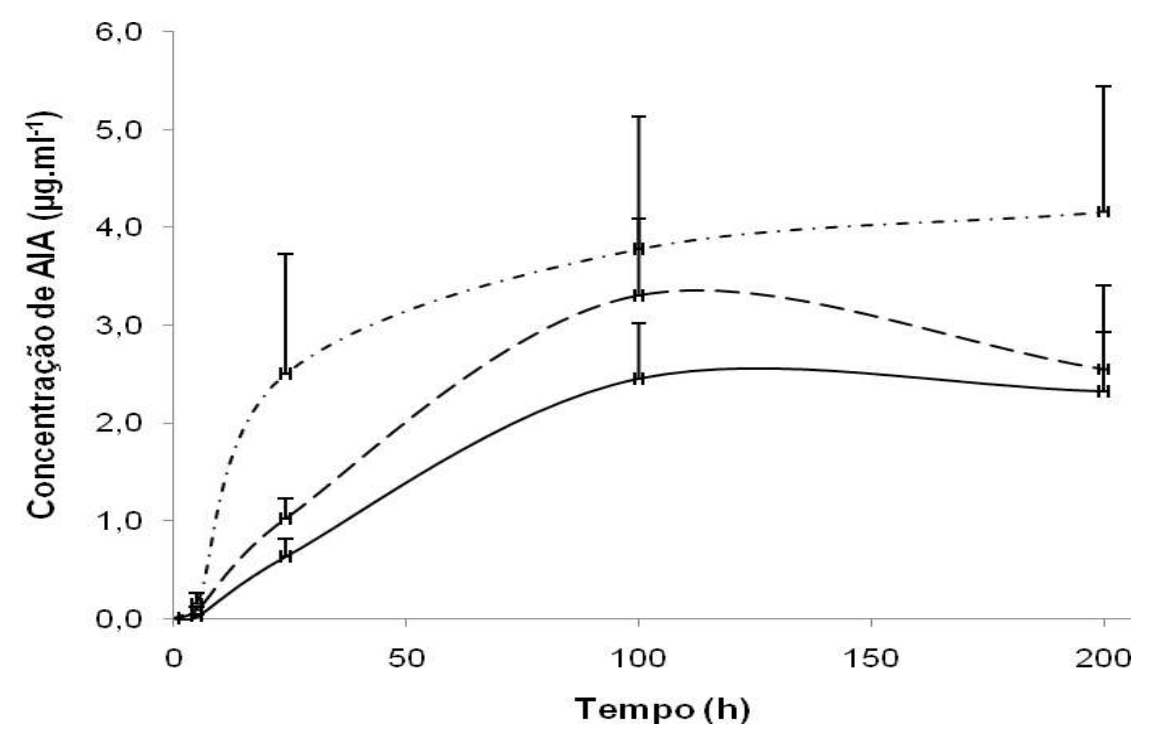

Figura 85 - Liberação média de AIA (levando-se em conta todos os isolados) e respectivo erro padrão, ao longo do tempo, em culturas de bactérias isoladas de cana-de-açúcar adubada organicamente $(-)$, convencionalmente ( - ) ou controle (- - ). 
A liberação de etileno foi maior em culturas de isolados de cana-de-açúcar sem adubação que nas linhagens obtidas de plantas tratadas com algum tipo de fertilizante após $200 \mathrm{~h}$ (Tabela 9).

Tabela 9 - Concentrações médias de substâncias liberadas por bactérias isoladas de cana-de-
açúcar submetida ao tratamento orgânico, convencional ou controle e respectivos
erros padrão, levando em conta apenas o pico de liberação de cada substância.
Diferentes letras indicam diferenças significativas entre os tratamentos pelo teste de
ANOVA $(P=0,05)$




\section{DISCUSSÃO}

As bactérias utilizadas para estudo do presente trabalho foram escolhidas aleatoriamente dentre cerca das 150 isoladas em nosso laboratório. A escolha foi feita com base apenas nas diferenças morfológicas das colônias, na competência de crescer em meio isento de $\mathrm{N}$-combinado e na capacidade de redução de acetileno. Essas bactérias foram identificadas pelo sequenciamento do gene 16S rRNA em outro projeto, desenvolvido em nosso laboratório, por outro aluno. O sequenciamento do gene $16 \mathrm{~S}$ rRNA, que compõe parte da subunidade $30 \mathrm{~S}$ do RNA ribossômico, é um método amplamente utilizado para se identificar gêneros bacterianos isolados dos mais diferentes ambientes (ZHANG; XU, 2008; MONTAÑEZ et al., 2009). A parte $16 S$ do ribossomo consiste em 1542 bases e contém os sítios A-, P- e E- de ligação do tRNA (WIMBERLEY et al., 2000). Este gene se manteve conservado durante a evolução sendo por isso utilizado para inferência taxonômica com bastante segurança. As informações fornecidas pelo sequenciamento foram utilizadas neste trabalho para se obter a identificação no nível de gênero, justamente pelo gene 16S ser preservado, não sendo informativo o suficiente para alcançar o nível de espécie.

Os dados de identificação fornecidos pelo outro projeto apontavam um número elevado de enterobactérias, sendo a maioria pertencente ao gênero Klebsiella. Assim, foi incluído, no projeto, outro objetivo que visava identificar, no nível de espécie, bactérias pertencentes a esse gênero. $O$ intuito era de avaliar se as liberações de SPCV variavam dentro da mesma espécie. O método utilizado para a identificação no nível de espécie foi o sequenciamento de genes "housekeeping". Estes consistem em genes essenciais para a manutenção celular, codificando proteínas indispensáveis para 
a célula. Genes "housekeeping" apresentam maior variabilidade que o $16 \mathrm{~S}$ rRNA sendo assim mais informativos. Apenas o seqüenciamento de um desses genes não é suficiente para se identificar uma bactéria em nível de espécie. Naser et al. (2005) aplicaram a metodologia de MLSA utilizando seqüências parciais de dois desses genes aliados ao seqüenciamento do gene $16 \mathrm{~S}$ rRNA para identificar linhagens de Enterococcus em nível de espécie.

Durante a tentativa de amplificação desses genes, houve certa dificuldade técnica, pois alguns DNAs de bactérias não eram reconhecidos pelos iniciadores desenhados para o gênero Klebsiella. Assim, buscou-se verificar possíveis problemas na identificação inicial feita nos 36 isolados estudados. Observou-se que os fragmentos amplificados, purificados e sequenciados do gene $16 \mathrm{~S}$ rRNA possuiam um tamanho sempre inferior a 600 pares de base sendo assim, pouco confiáveis.

Com o objetivo de se obter melhores resultados, foram feitos sequenciamentos de fragmentos sempre maiores que 1300 pares de base. Os novos dados obtidos (Tabela 10) comprovaram a pouca confiabilidade da utilização de um fragmento curto do gene 16S rRNA para a identificação bacteriana, pois observaram-se mudanças inclusive no nível de família. Por exemplo, as bactérias que foram anteriormente identificadas como Azoarcus, Rhizobium e Burkholderia foram todas identificadas como Enterobacter, devido à melhor adequação da técnica. Concluídas as identificações com o uso de fragmentos maiores do gene 16S rRNA, os dados evidenciaram o predomínio das enterobactérias. Devido às alterações das identificações os estudos propostos para o gênero Klebsiella tiveram que ser postergados. É provável que futuramente estes 
sejam desenvolvidos com o gênero Enterobacter.

Tabela 10 - Linhagens bacterianas identificadas por sequenciamento do gene 16S rRNA. Diferenças encontradas entre as identificações obtidas com fragmentos menores que $600 \mathrm{pb}$ e maiores que $1300 \mathrm{pb}$. ND - Não determinada.

\begin{tabular}{|c|c|c|}
\hline Linhagem & $<600 \mathrm{pb}$ & $>1300 \mathrm{pb}$ \\
\hline ICB21 & Herbaspirillum sp. & Herbaspirillum sp. \\
\hline ICB22 & Enterobacter sp. & Enterobacter sp. \\
\hline ICB101 & Klebsiella sp. & Enterobacter sp. \\
\hline ICB105 & Klebsiella sp. & Enterobacter sp. \\
\hline ICB115 & Klebsiella sp. & Klebsiella sp. \\
\hline ICB117 & Acinetobacter sp. & $N D$ \\
\hline ICB118 & Rhizobium sp. & Enterobacter sp. \\
\hline ICB508 & Herbaspirillum sp. & Herbaspirillum sp. \\
\hline ICB522 & Burkholderia sp. & Enterobacter sp. \\
\hline ICB525 & $N D$ & Enterobacter sp. \\
\hline ICB528 & $N D$ & Enterobacter sp. \\
\hline ICB532 & $N D$ & Enterobacter sp. \\
\hline ICB365 & Klebsiella sp. & Klebsiella sp. \\
\hline ICB369 & Klebsiella sp. & Klebsiella sp. \\
\hline ICB371 & Pseudomonas sp. & Pseudomonas sp. \\
\hline ICB375 & Klebsiella sp. & Klebsiella sp. \\
\hline ICB379 & Chryseobacterium sp. & Chryseobacterium sp. \\
\hline ICB383 & Pseudomonas sp. & Pseudomonas sp. \\
\hline ICB479 & Burkholderia sp. & Enterobacter sp. \\
\hline ICB481 & Klebsiella sp. & Enterobacter sp. \\
\hline ICB551 & Enterobacter sp. & Enterobacter sp. \\
\hline ICB553 & Klebsiella sp. & Klebsiella sp. \\
\hline ICB557 & Gluconoacetobactersp. & Gluconoacetobacter sp. \\
\hline ICB561 & Enterobacter sp. & Enterobacter sp. \\
\hline ICB386 & Pantoea sp. & Rhizobium sp. \\
\hline ICB397 & Pantoea sp. & Grimontella sp. \\
\hline ICB405 & Pantoea sp. & Enterobacter sp. \\
\hline ICB409 & Erwinia sp. & Erwinia sp. \\
\hline
\end{tabular}

Continua 


\begin{tabular}{ccc} 
Conclusão & & \\
\hline Linhagem & $<600 p b$ & $>$ 1300pb \\
\hline ICB439 & Rhizobium sp. & Klebsiella $s p$. \\
ICB464 & Azoarcus sp. & Enterobacter $s p$. \\
ICB565 & $N D$ & Klebsiella $s p$. \\
ICB567 & $N D$ & Enterobacter $s p$. \\
ICB568 & Herbaspirillum sp. & Herbaspirillum $s p$. \\
ICB569 & Enterobacter sp. & Enterobacter $s p$. \\
ICB572 & $N D$ & Enterobacter $s p$. \\
ICB573 & $N D$ & Klebsiella $s p$. \\
\hline
\end{tabular}

O gênero mais abundante passou a ser Enterobacter, com 17 isolados. Foram ainda Identificadas oito linhagens de Klebsiella, três de Herbaspirillum, duas de Pseudomonas, e uma de cada um dos gêneros Rhizobium, Grimontella, Chryseobacterium, Gluconacetobacter, Erwinia e Acinetobacter. Pela primeira vez são descritos o isolamento e identificação de Rhizobium, Chryseobacterium e Grimontella em cana-de-açúcar.

A grande quantidade de enterobactérias obtidas está de acordo com trabalho de Magnani et al. (2010) que demonstraram alta porcentagem desses microrganismos em amostras de cana-de-açúcar obtidas no estado do Paraná. Herbaspirillum e Gluconacetobacter são bactérias extensamente estudadas em associação com esse vegetal. Em virtude deste fato, a EMBRAPA desenvolveu, nos últimos anos, um inoculante para cana-de-açúcar que inclui diferentes linhagens de Gluconacetobacter, Herbaspirillum, Burkholderia e Azospirillum. A inoculação de misturas de linhagens desses gêneros em cana-de-açúcar mostrou resultados positivos de acúmulo de 
biomassa (OLIVEIRA et al., 2002)

Os gêneros Klebsiella e Enterobacter podem ser encontrados em uma grande variedade de ambientes. Foram primeiramente descritos como enterobactérias por habitarem o trato intestinal humano podendo inclusive se instalar no hospedeiro com relativa facilidade e adquirir resistência a antibióticos (WIENER et al., 1999; SOGE; ADENIYI; ROBERTS, 2006; PAAW et al., 2009). Posteriormente foi descrita sua presença no solo, a competência de fixar nitrogênio e o endofitismo (IÑIGUEZ; DONG; TRIPLETT, 2004; SUN et al., 2007; ROESCH et al., 2008). Muitos trabalhos que visaram estudar aspectos fisiológicos da nitrogenase, como a inativação pelo $\mathrm{O}_{2}$, foram realizados com linhagens de Klebsiella (KAVANAGH; HILL, 1993). Aparentemente, os dois gêneros se caracterizam por sua versatilidade, podendo se adaptar e adquirir características que permitem seu estabelecimento em ambientes específicos. Neste estudo, mais da metade dos isolados identificados eram de enterobactérias (Klebsiella, Enterobacter, Grimontella e Erwinia) e diversos foram capazes de liberar SPCV. Podese propor que essas características consistam em uma vantagem que alguns isolados desses gêneros podem ter adquirido ao se associarem a vegetais. A filogenia das linhagens confirmou a proximidade das enterobactérias, bem como dos isolados de Herbaspirillum e Pseudomonas.

A identificação parcial do gene $16 \mathrm{~S}$ rRNA, feita inicialmente para as 150 linhagens diazotróficas isoladas de cana-de-açúcar que tiveram sua superfície desinfetada, apontou a presença de 12 linhagens de Rhizobium. Devido às dúvidas geradas pelo pequeno tamanho do fragmento amplificado, assim como aconteceu com 
o gênero Klebsiella, foi acrescentado ao presente trabalho o objetivo de identificar essas linhagens no nível de espécie. Para isso utilizou-se a o método do MLSA aliado ao seqüenciamento do gene $16 \mathrm{~S}$ rRNA. Os genes utilizados foram o recA e o gapA. $O$ gene $\operatorname{rec} A$ codifica a proteína recombinase A que é essencial para o reparo do DNA, recombinação homóloga e estabilidade genômica, o que evita mutações danosas para o microrganismo (LIN et al., 2006). O gene gapA codifica a subunidade A da enzima gliceraldeido-3-fosfato desidrogenase, que cataliza a transformação do glicereldeido-3fosfato a 1,3-bifosfoglicerato e é essencial para as vias de degradação de açúcares ou síntese de glicose (TOYODA et al., 2008).

No presente trabalho foram construídas duas árvores filogenéticas, pelos métodos da máxima parcimônia e de neighbour-joining a partir dos fragmentos concatenados dos genes recA (360pb), gapA (480pb) e 16S rRNA (1400pb) e ambas demonstraram a mesma topologia. Segundo Steckbrandt e Ebers (2006) índices maiores que $98,7 \%$ de similaridade do gene $16 \mathrm{~S}$ rRNA (ao invés de $97 \%$, limite adotado anteriormente) indicam que as linhagens estudadas pertencem à mesma espécie. No presente trabalho a matriz de similaridade apontou índices maiores que $98,7 \%$ entre os genes concatenados de: ICB506 e a linhagem tipo de Rhizobium tropici; ICB494 e a linhagem tipo de Rhizobium hainanense indicando que ICB506 e ICB494 são, respectivamente, $R$. tropici e $R$. hainanense. Por outro lado, a elevada porcentagem de similaridade entre ICB456, ICB503 e ICB504, sugere que estes isolados sejam da mesma espécie. Ensaios como de hibridização DNA/DNA devem ser realizados para confirmar esses dados. A posição de ICB493 e da linhagem tipo de $R$. etli na árvore filogenética indica grande proximidade $(97,2 \%)$, porém não o suficiente 
para serem consideradas da mesma espécie pelo limite estipulado por Stackbrandt e Ebers(2006). As posições de ICB456, ICB500, ICB503 e ICB504, distantes das linhagens tipo, sugerem que possam pertencer a novas espécies ainda não descritas. Novos testes são importantes para se determinar quais espécies de Rhizobium colonizam cana-de-açúcar, uma vez que, o isolamento de Rhizobium sp. endofítico de cana-de-açúcar foi aqui descrito pela primeira vez. Esse gênero, extremamente estudado e aplicado em campo em culturas de leguminosas, já foi isolado de plantas outras famílias tendo demonstrado sua capacidade de promover o crescimento dessas plantas. Mehboob, Naveed e Zahir (2009), em sua revisão, listam inúmeras linhagens de Rhizobium isoladas de não-leguminosas e efeitos positivos das inoculações dessas bactérias.

Conforme proposto em objetivos, o presente trabalho descreve a liberação de aminoácidos, poliaminas, AIA e etileno em diversos gêneros bacterianos diazotróficos endofíticos isolados de cana-de-açúcar.

De todas as bactérias estudadas, $61 \%, 22 \%$ e $17 \%$ produziram, respectivamente, dois, três e quatro diferentes SPCV. Apenas a linhagem ICB371, que incapaz de crescer em meio MS líquido, não pode ser avaliada quanto à liberação desses compostos.

Das substâncias analisadas, os aminoácidos, as poliaminas e o AIA são nitrogenados. Nos experimentos relativos à excreção de aminoácidos e poliaminas, a única fonte de nitrogênio no meio de cultura era o $\mathrm{N}_{2}$ atmosférico. Para avaliar se havia 
uma relação direta entre atividade enzimática e liberação dos compostos nitrogenados, medidos nesse trabalho, a atividade da nitrogenase foi determinada concomitantemente à produção dessas substâncias. Paralelamente, o crescimento bacteriano foi avaliado para relacionar liberações das SPCV às fases do crescimento.

Inicialmente foi possível observar isolados do mesmo gênero com diferentes taxas de redução de acetileno indicando que as nitrogenases dessas bactérias apresentavam atividades bastante diferentes. As concentrações dos produtos nitrogenados liberados, além de variarem muito entre si, não foram correspondentes à atividade enzimática detectada, temporal e quantitativamente. Da mesma forma, não foi possível observar relação entre quantidades de acetileno reduzido e do número máximo de células atingido pela população. Por exemplo, Herbaspirillum (ICB21) foi o isolado que apresentou atividade enzimática mais baixa, $0,04 \mathrm{fmol} \cdot \mathrm{ufc}^{-1} \cdot \mathrm{h}^{-1}$ durante $24 \mathrm{~h}$,

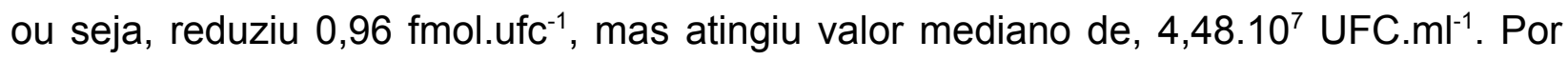
outro lado, o pico de atividade específica da nitrogenase da linhagem ICB508 foi de 6,49 fmol.ufc $\mathrm{f}^{-1} \cdot \mathrm{h}^{-1} \mathrm{em}$ cinco horas totalizando $32,45 \mathrm{fmol} \cdot \mathrm{ufc}^{-1}$. Sua população atingiu $3,00.10^{8}$ UFC. $\mathrm{ml}^{-1}$ e essa bactéria liberou maior quantidade de nitrogênio incorporado em aminoácidos $\left(457,69 \mathrm{ng}^{\mathrm{ml}} \mathrm{l}^{-1}\right)$. Estes dados indicam que o controle da multiplicação derivou a atividade celular para um caminho que favorece a interação bacteriana com outros seres, pela produção de SPCV. No entanto, nem sempre os resultados mostraram este direcionamento, pois outras bactérias que apresentaram elevada atividade da enzima, por um tempo grande, não atingiram esses valores, seja de população, ou de compostos nitrogenados. Este é o caso de Klebsiella (ICB105) cujo pico de atividade foi de 297,75 fmol. ufc $^{-1} \cdot \mathrm{h}^{-1} \mathrm{com}$ a enzima mantendo-se ativa por $100 \mathrm{~h}$. 
Esta bactéria não liberou nem aminoácidos nem poliaminas e o crescimento foi baixo, atingindo $2,01 \cdot 10^{7}$. A correlação da produção de AIA não foi considerada. A justificativa do porquê será dada mais adiante. Em Azotobacter vinelandii foi demonstrado que a taxa de redução de acetileno pela nitrogenase não é equivalente à de redução de $N_{2}$, (BERGERSEN, 1970). De fato, a diferença entre a capacidade de redução de acetileno e de fixação de $\mathrm{N}_{2}$ depende da linhagem bacteriana. Em algumas linhagens de $A$. chroococcum, a redução de acetileno é superior à fixação de nitrogênio, enquanto em outras da mesma espécie, ocorre o contrário (NIKOGOSIAN, 1983). Trabalhos mais recentes não relacionam fixação de nitrogênio com redução de acetileno, não tendo sido encontrada nenhuma explicação para essas diferenças.

Diversos autores consideram que, durante a evolução, a nitrogenase se manteve altamente conservada. No entanto, pequenas alterações estruturais que influenciariam muito sua capacidade de catálise podem ter ocorrido. Por exemplo, alterações na estrutura primária da nitrogenase, artificialmente induzidas, demonstraram que a substituição de um único aminoácido altera a afinidade pelo acetileno bem como a redução de prótons que ocorre simultaneamente (KIM; NEWTON; DEAN, 1995). Se modificações como estas aconteceram em grupos específicos, podem-se esperar respostas variadas dependendo do grupo avaliado, de acordo com a mudança ocorrida na enzima, levando a distintas quantidades de produto formado. Estas variações poderiam justificar diferentes taxas de redução de acetileno encontradas entre as linhagens. Dessa forma, é possível que a taxa de fixação de $N_{2}$ não seja refletida exatamente pelos valores de redução de acetileno, o que explica o elevado crescimento e produção de compostos nitrogenados liberados ao meio por bactérias 
com baixa capacidade de redução de acetileno. Outras possíveis justificativas para baixos valores de UFC em bactérias com alta taxa de redução de acetileno seriam: a eliminação de compostos nitrogenados diferentes daqueles medidos nesse trabalho como HCN e amônia (SELVAKUMAR et al., 2007) ou o armazenamento desse nitrogênio em reservas protéicas como as encontradas em Beijerinckia e Acinetobacter (MIYASAKA et al., 2003; ELBAHLOUL et al., 2005).

Os isolados de Klebsiella sp. (ICB115) e Pseudomonas sp. (ICB383) apresentaram uma característica particularmente interessante no caso do crescimento em meio isento de fonte de nitrogênio. Apesar das populações se multiplicarem por 7,53 e 4,44 gerações, respectivamente, em nenhum momento foi detectada atividade da nitrogenase via redução de acetileno. Uma possível explicação para esses resultados é a utilização de nitrogenases alternativas. Sabe-se que existem quatro tipos de nitrogenases: a clássica Molibdo-nitrogenase (Mo-Nase), a Vanadio-nitrogenase (VNase) a Ferro-nitrogenase (Fe-Nase) e a ainda pouco estudada nitrogenase superóxido dependente (sdn) (DILWORTH, 2004; GADKARI, 2004). A Fe-Nase e a Va-Nase têm menor afinidade pelo acetileno (HALES et al., 2004) enquanto a sdn não reduz esse substrato. Para evitar que as bactérias sintetizassem a Fe-Nase, no caso de

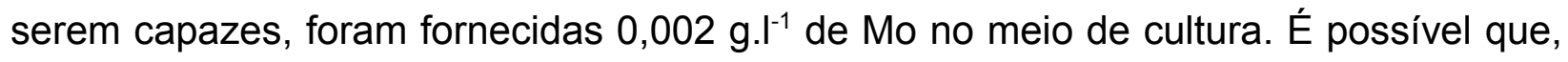
por possuírem diferentes rendimentos da nitrogenase clássica, algumas linhagens tenham esgotado o Mo do meio. Tanto a V-Nase como a Fe-Nase são enzimas que podem não só reduzir o acetileno a etileno, como também transformar o etileno em etano em taxas de até $7,4 \%$ (HALES, 2004). A Mo-Nase não cataliza a segunda reação, entretanto mutações em determinados aminoácidos, como a substituição da 
histidina por asparagina na subunidade alfa, posição 195 pode fazer com que a enzima clássica também reduza o etileno a etano (SCOTT; DEAN; NEWTON, 1992). No caso destas mutações terem ocorrido, as enzimas poderiam reduzir etileno a etano que não seria detectado pela técnica. Da mesma maneira, no caso inativação dos genes nif, resposáveis pela síntese e regulação da nitrogenase, o Fe contido no meio de cultura poderia ser usado na produção da enzima alternativa, Fe-Nase. Em qualquer caso, se a redução de acetileno não fosse muito elevada e a enzima sintetizada pela bactéria catalisasse a redução do etileno em porcentagens relativamente altas (próximas a 7\%), poderia ocorrer uma diminuição da concentração desse composto a níveis não detectáveis pela metodologia e aparelho utilizados, tornando muito difícil a compreensão e interpretação de como o nitrogênio estaria sendo incorporado pela bactéria, naquelas circunstâncias.

Uma explicação pouco provável seria a síntese da sdn, uma enzima que necessita de ions $\mathrm{O}_{2}^{-}$para reduzir o nitrogênio. Foi isolada de Streptomyces termoautotrophicus e possui estrutura totalmente diferente das outras. Essa enzima não é capaz de reduzir acetileno (RIBBE; GADKARI; MEYER, 1997) e caso uma bactéria possuísse esse sistema, a detecção da atividade pelo método utilizado nesse estudo não seria possível. Não há trabalhos na literatura que demonstrem que linhagens bacterianas, incapazes de reduzir acetileno, tenham grande aumento populacional ao serem cultivadas em meio isento de $\mathrm{N}$-combinado. Assim, era impossível prever os resultados aqui obtidos. Nossos dados mostram que esta técnica pode conduzir a interpretações incorretas, mas, até o momento é o método mais rápido e não há descrição de outro capaz de substituí-lo. 
A linhagem de Pseudomonas sp. ICB371 não foi capaz de crescer em meio MS líquido. O oxigênio é tóxico para a enzima nitrogenase e uma concentração inadequada desse elemento pode inibir a atividade dessa enzima. Bactérias diazotróficas possuem mecanismos protetores que impedem a inativação da enzima ao $\mathrm{O}_{2}$ (BECANA; RODRÍGUEZ-BARRUECO, 1989), ou, para se desenvolver, devem estar em condições adequadas de baixa tensão de $\mathrm{O}_{2}$. No presente estudo as bactérias foram mantidas em meios semi-sólidos, preparados com baixa concentração de ágar que promove menor difusão de oxigênio no meio pelo aumento da tensão superficial. Devido à necessidade de dosar substâncias livres no meio, os experimentos foram realizados em meio líquido. É possível que a nitrogenase da linhagem ICB371 seja mais sensível e que a concentração de $\mathrm{O}_{2}$ presente no meio líquido tenha inativado a nitrogenase clássica, sem que outra enzima alternativa tenha sido ativada.

Não se observou correlação entre os tempos em que as substâncias nitrogenadas foram excretadas e o período em que a redução de acetileno foi observada. Em alguns isolados as liberações de aminoácidos, poliaminas e AIA ocorreram simultaneamente ao período de atividade da enzima detectado, porém, em outros, não se observou essa simultaneidade. A literatura não apresenta trabalhos que relacionem a atividade específica da nitrogenase ao longo do tempo com a produção de promotores de crescimento.

Até o momento, poucos trabalhos foram feitos com o intuito de analisar a liberação de aminoácidos por bactérias diazotróficas. No presente estudo, $36 \%$ dos 
isolados demonstraram essa característica. Os gêneros excretores foram Herbaspirillum, Enterobacter, Klebsiella e Acinetobacter. Não há registros, na literatura, de liberação de aminoácidos por bactérias desses gêneros, exceção feita a Acinetobacter descrita por Liba et al. (2006). Neste trabalho, nem todas as bactérias do mesmo gênero foram capazes desta excreção. Considerando os quatro gêneros, $67 \%$ das linhagens de Herbaspirillum, $41 \%$ das de Enterobacter e $50 \%$ das de Klebsiella excretaram essas substâncias. Pseudomonas, Gluconacetobacter, Chryseobacterium, Grimontella e Rhizobium não liberaram aminoácidos, no entanto, Liba et al. (2006) detectaram esses compostos em culturas de Pseudomonas, isoladas de líquens. Isto indica que essa característica depende da linhagem estudada. A inoculação de canade-açúcar com Pantoea aumentou a quantidade de diversos aminoácidos no xilema da planta, provavelmente resultado da liberação desses compostos pelas bactérias ou pela resposta da planta à colonização (LOIRET et al., 2009).

Pela primeira vez, são demonstradas as capacidades de excreção ativa de aminoácidos por linhagens de Klebsiella sp., Enterobacter sp. e Herbaspirillum sp. As maiores diversidades de aminoácidos foram excretadas pelos isolados de Herbaspirillum, ICB21 (10 diferentes) e ICB508 (7). ICB508 foi também a linhagem que liberou esses compostos em maior quantidade, evidenciando o grande potencial deste gênero em suprir a planta com doses de nitrogênio combinado o que the conferiria uma vantagem na colonização do vegetal. Existem diferentes mecanismos pelos quais bactérias promotoras de crescimento vegetal contribuem com a nutrição do hospedeiro. Dentre eles está a FBN que aumenta a disponibilidade de nutrientes nitrogenados. Trabalhos com cana-de-açúcar e arroz (PIMENTEL et al., 1991; JAMES et al., 2002) 
evidenciam que linhagens de Herbaspirillum promovem o crescimento vegetal baseado na capacidade de fixar nitrogênio in situ. Apesar desse fato, até hoje, não se descreveu o mecanismo pelo qual do nitrogênio fixado é transferido da bactéria endofítica diazotrófica para a planta. Uma das formas em que esta poderia ocorrer seria pela liberação de compostos nitrogenados, como os aminoácidos.

$\mathrm{Na}$ planta, logo que absorvidos, os aminoácidos são transformados principalmente em glutamato, glutamina e asparagina. Nessas formas, podem ser transportados das raízes para as partes aéreas da planta ou ainda serem usados como precursores de diferentes aminoácidos que darão origem a outras biomoléculas (BUCHANAN; GRUISSEM; JONES, 2002). Diversos trabalhos mostram que bactérias endofíticas colonizam o interior do xilema e espaços intercelulares do vegetal (JAMES et al., 1994; JAMES; OLIVARES, 1997; GYANESHWAR et al., 2001). Liberados no xilema, os aminoácidos não passariam pelo processo de absorção pelas células das raízes e seriam liberados diretamente na seiva ascendente, podendo chegar à parte aérea sem necessidade de transformações em aminoácidos intermediários. Por exemplo, a Gly, que é precursora da clorofila (PORRA, 1986), foi liberada por algumas bactérias nesse estudo. Quando na planta, a liberação direta no xilema permitiria que a Gly atingisse as folhas, já na forma de ser convertida no pigmento, tornando a produção da clorofila mais rápida e eficiente. Tyr e Phe são precursores de lignina, compostos fenólicos, como os ácidos cinâmico e cumárico, e flavonas que estão envolvidos em defesas do vegetal e dormência das sementes (SINHA, 2004). O glutamato é um aminoácido chave para o crescimento, biossíntese de clorofila, funcionamento de meristemas e processos de frutificação (TAIZ; ZEIGER, 2002). 
A excreção ativa de aminoácidos foi descrita em Corynebacterium glutamicum e Escherichia coli cultivadas em meio rico em peptídeos. A degradação desses peptídeos gera altas concentrações de determinados aminoácidos, tornando necessária sua excreção para diminuir seus níveis intracelulares (EGGELING; SAHM, 2003). No presente estudo, as bactérias foram cultivadas em meio carente de $\mathrm{N}$-combinado. Se a nitrogenase fixar $\mathrm{N}_{2}$ em taxas maiores do que as necessárias para a manutenção da cultura pode ocorrer acúmulo de determinados aminoácidos no citoplasma e a excreção regularia os níveis intracelulares desses compostos, impedindo a inibição da enzima (PATI et al., 1994).

Em relação aos tipos de adubação, os dados do presente trabalho mostram uma influência positiva da adubação orgânica sobre a liberação de aminoácidos por bactérias endofíticas. O maior número de bactérias capazes de liberar aminoácidos, as maiores concentrações e diversidade desses compostos foram obtidos de isolados de plantas submetidas a esse tratamento. Leita et al. (1999) mostraram que a fertilização orgânica pode aumentar a biomassa e o metabolismo microbiano nos solos. Por outro lado, a adubação convencional pode influenciar negativamente no número de bactérias endofíticas, dependendo do gênero. Gluconacetobacter diazotrophicus foi eliminado quando submetido à adubação convencional, entretanto o mesmo efeito não foi detectado em Herbaspirillum spp (MUTHUKUMARASAMY; REVATHI; LAKSHMINARASIMHAN, 1999).

Apesar dos experimentos deste estudo terem sido realizados "in vitro", os resultados mostram que as bactérias apresentam potencial que poderá beneficiar 
grandemente as plantas, caso liberem aminoácidos quando endofíticas. Essas bactérias possuem a capacidade de produzir todos os aminoácidos de que necessitam para seu crescimento, usando nitrogênio molecular como única fonte desse elemento. Plantas como a cana-de-açúcar possuem uma relação $\mathrm{C} / \mathrm{N}$ muito alta, necessitando assim de pouca quantidade de aminoácidos para acumular sensíveis quantidades de açúcar. Quando liberados ativamente dentro do vegetal, mesmo que em baixa quantidade, porém constantemente, esse suprimento poderá render quantidades consideráveis de $\mathrm{N}$-combinado à planta ao longo do tempo. Plantas como a cana-deaçúcar possuem uma relação $\mathrm{C} / \mathrm{N}$ muito alta, necessitando assim de pouca quantidade de aminoácidos para acumular sensíveis quantidades de açúcar. Assim, mesmo os valores excretados aquiUma vez liberados no xilema, os aminoácidos seriam logo transportados para outros tecidos do hospedeiro impedindo sua reabsorção pela bactéria.

A liberação de poliaminas por microrganismos endofíticos é outra característica pouquíssimo estudada. Pela primeira vez é descrita a capacidade de isolados de Klebsiella sp., Enterobacter sp., Erwinia sp., Acinetobacter sp., Grimontella sp., Chryseobacterium sp., Rhizobium sp. e Pseudomonas sp. liberarem esses compostos. O presente trabalho mostra que $33 \%$ de bactérias isoladas de cana-de-açúcar podem liberar poliaminas. As quantidades excretadas variaram entre $0,28 \mu \mathrm{g} \cdot \mathrm{ml}^{-1} \mathrm{e} 1,91 \mu \mathrm{g} \cdot \mathrm{ml}^{-1}$

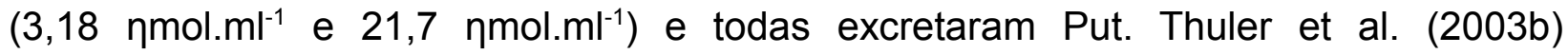
obtiveram concentrações de Put entre 0,70 e 5,67 $\mu \mathrm{g} \cdot \mathrm{ml}^{-1}$ em culturas de Beijerinckia derxii, enquanto Azospirillum sp. liberou 0,19 $\mu \mathrm{g} \cdot \mathrm{ml}^{-1}$ (THULER et al., 2003a). As poliaminas a Put, a Spd e a Spm são universais; derivados da Arg e da Lys (HOPKINS, 
2008) são sintetisadas pela mesma via (TAIZ; ZIEGER, 2002). Os aminoácidos precursores são transformados em Orn, depois em Put, em seguida em Spd e por fim em Spm. Segundo Galston e Kaur-Sawhney (1995), é provável que todas as células sejam reguladas por interferência de Put e Spd, enquanto a Spm deve ser funcional apenas em células eucarióticas. Este trabalho mostra que Spm pode ser sintetizada por Enterobacter sp. (ICB101). Thuler et al. (2003a) descreveram a liberação de Spm por uma linhagem endofítica de Azospirillum sp. A liberação de poliaminas dentro da planta, por ação bacteriana, pode contribuir para o crescimento dos frutos, a senescência das folhas, o desenvolvimento de órgãos reprodutores, a diferenciação da raiz, a prevenção contra radiação UV-C e degradação protéica por desequilíbrio osmótico, entre outros (TAIZ; ZIEGER, 2002), uma vez que as poliaminas regulam todos esses processos. No presente estudo, houve liberação de Spm por uma linhagem de Enterobacter (ICB101) em concentrações de $0,11 \mu \mathrm{g} \cdot \mathrm{ml}^{-1}$. A excreção de Spm por Azospirillum sp. em cultura pura foi descrita por Thuler et al. (2003a) em concentrações de 1,5 $\mu \mathrm{g} \cdot \mathrm{ml}^{-1}$. Em consequência do escasso estudo sobre liberação de poliaminas por bactérias, não se conhece ainda o nível de contribuição, para a planta, desses reguladores produzidos pelos microrganismos. As concentrações de poliaminas livres em caules de plântulas podem variar dependendo do vegetal. As maiores concentrações de Put encontradas foram de 59.5 nmol.g ${ }^{-1}$ de peso fresco, em pimenta (Capsicum annum) e as menores ocorreram em espinafre (Spinacia oleracea) e beterraba (Beta vulgaris) que apresentaram 12,8 e 7,4 nmol.g $^{-1}$ de peso fresco, respectivamente (ZAPATA et al., 2008). As concentrações liberadas por bactérias aqui estudadas, cujos picos variaram

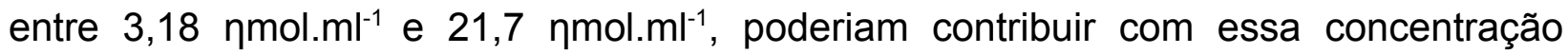
endógena se essa excreção ocorresse nas plantas. 
Diferentemente da liberação dos outros compostos estudados neste trabalho, a excreção de AIA por bactérias endofíticas é bastante conhecida (SPAEPEN; VANDERLEYDEN; REMANS, 2007). A excreção de AIA não havia sido descrita anteriormente em linhagens de Chryseobacterium sp. e Grimontella sp. É relevante que a liberação desse fitormônio tenha ocorrido em alta porcentagem nas bactérias endofíticas de cana-de-açúcar $(91,3 \%)$ e que todas as bactérias excretoras de aminoácidos ou poliaminas também produziram AIA. Como esse fitormônio é essencial, pois os vegetais dependem dele para crescer, deve estar presente em todas as plantas, sem exceção (TAIZ; ZIEGER, 2002). Acredita-se que esta característica, quando presente em bactérias, tenha sido adquirida ao longo do tempo, a partir de suas associações com plantas, provavelmente por transferência de genes do vegetal para o microrganismo. Em bactérias, foram encontradas duas vias de síntese principais presentes na grande maioria dos isolados, a da indol-acetamida (IAM) e a do ácido indol-pirúvico (IPA). Ambas possuem o Trp como precursor. Em plantas existe maior número de vias de síntese. Algumas usam o Trp como precursor, enquanto outras usam o indol. No entanto, a via do IPA é semelhante àquela encontrada nas bactérias (PATTEN; GLICK, 1996; SPAEPEN; VANDERLEYDEN; REMANS, 2007) o que reforça a possibilidade da característica ter sido adquirida por transmissão horizontal. Bactérias patogênicas tendem a sintetizar o AIA por via da IAM, enquanto microrganismos benéficos produzem este fitormônio principalmente por via do IPA (SPAEPEN; VANDERLEYDEN; REMANS, 2007).

Raramente estão descritas grandes porcentagens de bactérias com essa 
característica isoladas de um mesmo ambiente. Resultados similares aos aqui apresentados revelaram que $88 \%$ de 16 linhagens bacterianas provenientes de sementes de cevada excretaram o fitormônio (TUOMI; LAAKSO; ROSENQVIST, 1994). À semelhança desse trabalho, Bastian et al. (1998) detectaram o hormônio em culturas de linhagens endofíticas de Gluconacetobacter e Herbaspirillum. Linhagens de Pantoea, isoladas do interior de plantas ou liquens, mostraram capacidade de excretar AIA (VERMA; LAHDA; TRIPATH, 2001; HALDA-ALIJA, 2003; LIBA et al., 2006). Elkhawas e Adachi (1999) isolaram sete linhagens de Klebsiella capazes de excretar cinco diferentes auxinas. Acinetobacter, isolado de liquens e rizosfera de trigo, liberou AIA (LIBA et al., 2006; SARODE et al., 2009) assim como diversas linhagens de Burkholderia (TABACCHIONI et al., 1993; HALDA-ALIJA, 2003; KUKLINSKI-SOBRAL, 2004). Mirza et al. (2001) descreveram quatro isolados de Enterobacter produtores de AIA. Torres-Rubio et al. (2000) detectaram AIA em culturas de Pseudomonas sp. em meio TSB suplementado com $0,2 \%$ de triptofano após $54 \mathrm{~h}$ de crescimento. Um isolado epifítico de Erwinia herbicola foi estudado como produtor de AIA e teve sua via de síntese caracterizada (BRANDL; LINDOW, 1996). Além das demonstrações in vitro da potencialidade de excreção de AIA, há evidências de sua liberação in vivo. Rhizobium é um gênero extremamente estudado em associações com plantas, principalmente por promover efetiva contribuição para o crescimento de plantas leguminosas. Além da liberação de $\mathrm{N}$-combinado, também foram encontrados altos índices de AIA em nódulos, sugerindo que a bactéria libera o fitormônio nesse local (DULIAART et al., 1970; HUNTER, 1986). Hoje se sabe que o gênero Rhizobium é capaz de liberar AIA também em cultura pura (BISWAS; LADHA; DAZZO, 2000). Outros gêneros produtores são Azospirillum (THULER et al., 2003a), Beijerinckia (THULER et al., 2003b), 
Agrobacterium e Bradyrhizobium (COSTACURTA; VANDERLEYDEN, 1995).

As concentrações de AIA obtidas neste trabalho variaram de 0,30 a 15,02 $\mu \mathrm{g} \cdot \mathrm{ml}^{-1}$. Alguns trabalhos mostram concentrações semelhantes do hormônio obtidas em culturas bacterianas. Azospirillum produziu aproximadamente $12 \mu \mathrm{g} \cdot \mathrm{ml}^{-1}$ de AIA (THULER et al., 2003a). Entretanto há registros de linhagens que produziram até 67 $\mu \mathrm{g} \cdot \mathrm{ml}^{-1}$ (HALDA-ALIJA, 2003).

O nitrogênio combinado, proveniente da fixação não deve ter sido utilizado pela bactéria para produção de AIA, pois, as quantidades de triptofano fornecidas no meio, $0,5 \mathrm{~g} \cdot \mathrm{I}^{-1}$, contêm um total de aproximadamente $72 \mu \mathrm{g} \cdot \mathrm{ml}^{-1}$ do elemento N. Klebsiella sp. (ICB369) foi a bactéria que liberou maior quantidade de AIA, 15,02 $\mu \mathrm{g} \cdot \mathrm{ml}^{-1}$. O total de $\mathrm{N}$ utilizado na produção do fitormônio, por esta bactéria, foi de aproximadamente 1 $\mu \mathrm{g} \cdot \mathrm{ml}^{-1}$. B.derxii excretou maior quantidade de AIA em presença de sulfato de amônio que em meio com $\mathrm{N}_{2}$ (THULER et al., 2003b) indicando que a presença de $\mathrm{N}$ combinado favorece a produção desse fitormônio. Alguns trabalhos mostram que o AIA pode ser produzido por bactérias mesmo sem adição de triptofano, porém concentrações muito maiores são obtidas fornecendo-se o precursor (PEDRAZA et al., 2006). Na planta, o AIA é produzido principalmente no meristema apical e daí é transportado para as outras partes do vegetal (TAIZ; ZIEGER, 2002). Caso haja a liberação de AIA pelas bactérias endofíticas que colonizam xilema, esse fitormônio poderá ser transportado diretamente pela seiva bruta para as regiões superiores da planta, aumentando a concentação de AIA nesses locais. O AIA produzido pelas bactérias poderá auxiliar na promoção de crescimento, extensão da parede celular, aumento das raízes laterais e adventícias, desenvolvimento de frutos, entre outros 
(TAIZ; ZIEGER, 2002). No entanto, a quantidade de AIA no interior da planta deve ser controlada. Dependendo do fenótipo do vegetal, variações nas concentrações do hormônio podem alterar seu crescimento (SPAEPEN; VANDERLEYDEN; REMANS, 2007). Por exemplo, linhagens de Pseudomonas superprodutoras de AIA causaram inibição do crescimento de Arabidopsis (PERSELLO-CARTIEAUX; NUSSAUME; ROBAGLIA, 2003).

Não foram encontradas diferenças significativas entre as curvas de liberação de poliaminas e AIA dos isolados dos diferentes tipos de adubação. Isso se deve ao fato de que muitas bactérias apresentaram resultados negativos para poliaminas, o que ampliou muito o intervalo de confiança dos pontos de cada curva. Mesmo aplicando-se um método não paramétrico e transformando os dados por aplicação do logarítmo de cada valor, não houve possibilidade de homogeneizar as amostras. Assim, tornou-se impossível verificar as diferenças, embora os gráficos de liberação de AIA e poliaminas, ao longo do tempo, indiquem que bactérias isoladas de plantas tratadas convencionalmente têm maior capacidade de liberar essas substâncias.

O etileno foi produzido por 31 das 36 bactérias estudadas (86\%). As concentrações variaram entre 1,07 e 12,96 nmol.ml ${ }^{-1}$. Aproximadamente $30 \%$ dos microrganismos dos solos produzem etileno a uma taxa de $100 \eta \mathrm{\eta l.}^{-1} \cdot \mathrm{h}^{-1}$. Porém, baixa concentração fica ai retida, pois a maior quantidade se dispersa para o ar (GRICHKO; GLICK, 2001). Dentre os gêneros estudados nesse trabalho a liberação de etileno nunca havia sido descrita em bactérias pertencentes aos gêneros Acinetobacter sp., Grimontella sp., Chryseobacterium sp., e Herbaspirillum sp. Por outro lado, Erwinia, 
Enterobacter, Klebsiella, Pseudomonas e Rhizobium foram previamente descritos como produtores de etileno (FUKUDA; OGAWA; TANASE, 1993).

Como o etileno possui várias funções nos vegetais, a presença de bactérias endofíticas produtoras, poderia contribuir de diversas formas, dependendo de sua localização e do estágio de desenvolvimento da planta. Dentre essas funções, pode-se destacar a quebra de dormência de sementes, epinastia foliar, formação dos ganchos plumulares em ausência de luz, formação de raízes e pelos, indução de floração e defesa contra infecções e ferimentos. Em determinadas plantas, como a cana-deaçúcar, outros efeitos do etileno são importantes por promoverem diminuição do alongamento celular e crescimento lateral das células que promovem aumento do conteúdo de açúcares. Em cana-de-açúcar o elevado acúmulo de sacarose valoriza sua cultura. A presença das bactérias que produzam etileno endoficamente também poderia contribuir para a regulação do crescimento vegetal e aumento da concentração de açúcar num processo que atualmente é induzido por produtos industrializados chamado maturação (LI; SOLOMON, 2003). Este hormônio é também produzido em resposta a patógenos, causando reação de necrose do tecido vegetal, para isolar o foco da doença. O etileno mostrou-se fundamental para a defesa da planta em casos de doenças causadas por fungos necrotróficos e fungos do solo, que normalmente não são patogênicos, mas se tornam por razões desconhecidas (HAMOND-KOSACK; JONES, 2000). O etileno é funcional na planta em concentrações de até $4,4 \mathrm{ng}^{-\mathrm{l}^{-1}}$, menores que as encontradas neste trabalho. Entretanto, aqui, devido às condições experimentais, o etileno acumulou-se no frasco de ensaio, não refletindo o que ocorre in vivo. Na planta, caso este fosse produzido, se dispersaria pelos tecidos. Diversas 
espécies vegetais, incluindo gramíneas como arroz e cana-de-açúcar, apresentam receptores de etileno capazes de reconhecer bactérias endofíticas (CHEN; ETHERIDGE; SCHALLER, 2005; CAVALCANTE et al., 2007). Isso indica uma atuação do etileno na colonização dessas plantas. O fato da linhagem ICB568 ser capaz de produzir etileno apenas nas primeiras $144 \mathrm{~h}$ de cultivo pode ser um fator favorável, caso ocorra da mesma maneira na natureza. Essa liberação inicial seria necessária para o reconhecimento pela planta, porém, após a colonização, caso houvesse um excesso de etileno, o fato da bactéria cessar a síntese do fitormônio evitaria possíveis prejuízos ao vegetal. A penetração de bactérias para o interior das plantas pode ocorrer de diferentes maneiras; a ativação de receptores por etileno seria um exemplo. Outro mecanismo seria a liberação de enzimas capazes de hidrolisar a parede celular vegetal, criando espaços para a entrada bacteriana. Neste caso os genes de produção de enzimas celulolíticas e pectinolíticas seriam ativados apenas durante a penetração no vegetal de modo a evitar danos no interior do hospedeiro (VERMA; LAHDA; TRIPATHI, 2001). De maneira similar, no caso do etileno, a expressão dos genes responsáveis por sua síntese seria reprimida, quando as bactérias atingissem o interior do vegetal.

O precursor direto do etileno é o 1-aminociclopropano-1-carboxilato (ACC). Este composto, quando liberado na planta, atua da mesma forma que o etileno. Diversas bactérias possuem a capacidade de produzir uma enzima que cliva o ACC (ACC deaminase) fazendo com que o etileno não seja produzido e, consequentemente, não há efeito no vegetal (GLICK, 2005). No presente trabalho a produção de etileno ocorreu em $86 \%$ dos isolados, o que indica que essas bactérias não possuem a capacidade de 
sintetizar a ACC deaminase ou suprimiram sua produção. Até há pouco tempo, o etileno era tido como um fitormônio, que, quando produzido em quantidades significativas por bactérias ou aplicado por fontes exógenas, prejudicava o crescimento vegetal. Estudos recentes mostram que, dependendo da planta, uma concentração maior de etileno faz com que o vegetal cresça mais rapidamente. Entretanto, uma superexposição a este hormônio acaba se tornando danosa (PIERIK et al., 2006). É possível supor, pela análise estatística, que a maior produção de etileno bacteriano, aliada à menor excreção de aminoácidos pelos microrganismos, contribua com a diminuição do crescimento da cana-de-açúcar já prejudicado pela falta de adubação.

A literatura mostra que a inoculação em plantas de linhagens com capacidade de solubilizar nutrientes ou liberar SPCV como AIA pode auxiliar o desenvolvimento do hospedeiro de diversas formas. A inoculação de Azospirillum em trigo resultou em diminuição do comprimento da raiz, com sensível aumento de pelos radiculares que aumentam a superfície de absorção de nutrientes (SPAEPEN et al., 2008). Coinoculações de Pseudomonas e Rhizobium galegae em Galega orientalis Lam., uma planta leguminosa, aumentou o número de nódulos nas raízes (ENGAMBERDIEVA et al., 2010) o que resulta em maior fixação de $\mathrm{N}_{2}$ e maior aporte de $\mathrm{N}$-combinado para a planta. O aumento da biomassa de Brassica juncea foi verificado após colonização por Achromobacter xylosoxidans tolerante a altas concentrações de cobre ou por misturas de Pseudomonas sp. e Bacillus megaterium resistente a níveis altos de níquel (MA; RAJKUMAR; FREITAS, 2009a,b). A presença de bactérias tolerantes aos metais protegeu a planta, impedindo o prejuízo do seu crescimento devido ao excesso desses metais no solo. 
O presente trabalho mostra que as bactérias possuem diferentes habilidades relacionadas à promoção de crescimento vegetal. A liberação dos compostos, aqui demonstrada, pode ser interpretada como um meio de estímulo de crescimento vegetal. Dependendo do microrganismo essas características podem ter evoluído de forma diferente para favorecer a interação planta-bactéria. Assim, a diversidade bacteriana encontrada em cana-de-açúcar é um importante fator que contribui para o crescimento das plantas, pois é capaz de disponibilizar maior gama de promotores de crescimento vegetal ajudando mais das necessidades da planta.

Apesar da transferência de genes entre diferentes espécies ter ocorrido entre todos os grupos de seres vivos, ela aparece mais frequentemente em procariotos. Uma alternativa para se incorporar novos genes num genoma receptor é pelo estabelecimento de associação estável e passível de transferência vertical que complemente a capacidade metabólica do organismo receptor (MORAN, 2007). Existem na natureza interações entre bactérias e plantas onde devem ter ocorrido trocas gênicas entre procariotos e eucariotos, benéficas para ambos os parceiros. Um exemplo bastante estudado é o da associação rizóbio-leguminosa, onde a bactéria possui genes próprios como os da fixação de $\mathrm{N}_{2}$, cuja expressão é extremamente vantajosa para a planta e sua regulação depende dos dois organismos envolvidos. Além destes genes, a bactéria possui genes cujo produto aparentemente é benéfico apenas para a planta. De maneira similar as bactérias endofíticas facultativas ou obrigatórias apresentam genes exclusivos, como é o caso das diazotróficas e também aqueles que provavelmente foram recebidos das plantas e que atuam favorecendo a 
ambos os organismos. Exemplo de substâncias ativas em plantas, produzidas por bactérias, foram descritas neste trabalho.

É comum, ao longo da evolução, que organismos em associação tenham perdido genes responsáveis pela síntese de compostos essenciais para a sobrevivência daquela determinada espécie. Normalmente esses genes pertencem a vias metabólicas longas e envolvem muito gasto energético. A perda dos genes que codificam estas vias, não causa impacto negativo sobre o organismo, pois a substância codificada por eles é fornecida pelo parceiro da associação que manteve os genes funcionais (MORAN, 2007). A comprovação da excreção de aminoácidos e poliaminas por bactérias endofíticas pode ser um indício de que plantas, no futuro, possam perder genes responsáveis por sua síntese sem prejuízo ao vegetal.

Os dados obtidos no presente trabalho mostram que a adubação orgânica estimulou a produção de aminoácidos pelos isolados bacterianos, não interferiu na excreção de AIA e de poliaminas. Observou-se que, assim como a adubação convencional, a orgânica diminuiu a capacidade de produção de etileno pelas plantas de cana-de-açúcar. Como conclusão, pode-se propor que, em sendo menos onerosa e não interferindo negativamente em nenhum dos parâmetros estudados, a adubação orgânica é a mais adequada. 


\section{CONCLUSÕES}

$\checkmark$ BEFN isoladas de cana-de-açúcar são capazes de liberar ativamente aminoácidos e poliaminas produzidas a partir do $\mathrm{N}_{2}$ atmosférico em meio de cultura sintético (MMS)

$\checkmark$ Grande porcentagem de BEFN de cana-de-açúcar pode liberar os fitormônios AIA e etileno em meio contendo seus respectivos precursores

$\checkmark$ As BEFN capazes de liberar aminoácidos e/ou poliaminas possuem também a capacidade de produzir AIA

$\checkmark$ A porcentagem de BEFN excretoras de aminoácidos é maior em plantas adubadas organicamente e menor em plantas não adubadas

$\checkmark$ O tipo de adubação aplicado a cana-de-açúcar não interfere na porcentagem de BEFN capazes de excretar poliaminas, AIA e etileno

$\checkmark$ BEFN isoladas de cana-de-açúcar adubada organicamente podem excretar maior quantidade de aminoácidos que BEFN isoladas de plantas tratadas convencionalmente ou sem tratamento

$\checkmark$ O etileno é produzido em maior quantidade em bactérias isoladas de cana-deaçúcar sem adubação

$\checkmark$ O tipo de adubação não interfere na quantidade de poliaminas e AIA liberadas por BEFN

$\checkmark$ A maioria de BEFN cultiváveis presentes em cana-de-açúcar pertence ao grupo das enterobactérias

$\checkmark \quad$ Pelo menos quatro espécies diferentes de Rhizobium são capazes de penetrar plantas de cana-de-açúcar e permanecer no interior do vegetal tempo suficiente para 
serem isolados após desinfecção externa da planta

\section{REFERÊNCIAS*}

AHMAD, F.; AHMAD, I.; KHAN M. S. Screening of free-living rhizospheric bacteria for their multiple plant growth promoting activities. Microbiological Research, v. 163, p. 173-181, 2008.

ALEXANDER, A. G. Sucrose-enzime relationship in immature sugarcane affected by varying levels of nitrate and potassium supplied in sand culture. Journal of Agriculture of the University of Puerto Rico, v. 47, p. 165-229. 1964.

ANDERSON, M. D. et al. Estimating $\mathrm{N}_{2}$ fixation in two species of Alnus in interior Alaska using acetylene reduction and ${ }^{15} \mathrm{~N}_{2}$ uptake. Ecoscience, v. 11, p. 102-114, 2004.

ARSHAD, M.; FRANKENBERGER, W. T. Plant growth regulating substances in the rhizosphere: microbial production and functions. Advances in Agronomy, v. 62, p. 146-151, 1998.

ASTARITA, L. V.; FLOH, E. I. S.; HANDRO, W. Free amino acids, protein and water content changes associated with seed development in Araucaria augustifolia. Biologia Plantarum, v. 47, p. 53-59, 2004.

BAIS, H.; SUDHA, G.; RAVISHANKAR, G. A. Influence of putrescine, silver nitrate and polyamine inhibitors on the morphogenetic response in untransformed and transformed tissue of Cichorium intybus and their regenerants Plant Cell Reports, v. 20, p. 547-555, 2001.

BARBIERI, P. et al. Wheat inoculation with Azospirillum brasilense Sp6 and some mutants altered in nitrogen fixation and índole-3-acetic acid production. FEMS Microbiology Letters, v. 36, p. 87-90, 1986.

BARBOSA, H. R. et al. Counting of viable cluster-forming and non cluster-forming bacteria: a comparison between the drop and the spread methods. Journal of Microbiology Methods, v. 22, p. 39-50, 1995.

BASTIÁN, F. et al. Production of indole-3-acetic and gibberellins A1 and A3 by Acetobacter diazotrophicus and Herbaspirillum seropedicae in chemically-defined culture media. Plant Growth Regulation, v. 24, p. 7-11, 1998.

BECANA, M.; RODRIGUEZ-BARRUECO, I. Protective mechanism of nitrogenase against oxygen excess and partially reduced oxygen intermediates. Physiologia Plantarum, v. 75, p. 429-438, 1989. 
DE NORMAS TÉCNICAS. NBR 6023:

Informação e documentação: referências:

elaboração. Rio de Janeiro, 2002

BERGERSEN, F. J. The quantitative relationship between nitrogen fixation and the acetylene reduction assay. Australian Journal of Biological Sciences, v. 23, p. 10151025, 1970.

BERNER, D. K.; SCHAAD, N. W.; VÖLKSCH, B. Use of ethylene-producing bacteria for stimulation of Striga spp. seed germination. Biological Control, v. 15, p. 274-282, 1999.

BISWAS, J. C.; LADHA, J. K.; DAZZO, F. B. Rhizobia inoculation improves nutrient uptake and growth of lowland rice. Soil Science Society of America Journal, v. 64, p. 1644-1650, 2000.

BITONTI, A. J.; MCCANN, P. P.; SJOERDSMA, A. Restriction of bacterialgrowth by inhibition of polyamine biosynthesis by using monofluoromethylornithine, difluoromethylarginine and dicycloexylammonium sulphate. Biochemistry Journal, v. 208, p. 435-441, 1982.

BODDEY, R. M.; DÖBEREINER, J. Nitrogen fixation associated with grasses and cereals: recent results and perspectives for future research. Plant and Soil, v. 108, p. 53-65, 1988.

BODDEY , R. M. et al. Use of the ${ }^{15} \mathrm{~N}$ natural abundance technique for the quantification of the contribution of $\mathrm{N}_{2}$ fixation to sugar cane and other grasses. Australian Journal of Plant Physiology, v. 28, p. 889-895, 2001.

BODDEY, R. M. et al. Endophytic nitrogen fixation in sugarcane: present knowledge and future applications. Plant and Soil, v. 252, p. 139-149, 2004.

BRANDL, M. T.; LINDOW, S. E. Cloning and characterization of a locus encoding an indolepyruvate decarboxylase involved in indole-3-acetic acid synthesis in Erwinia herbicola. Applied and Environmental Microbiology, v. 62, p. 4121-4128, 1996.

BUCHANAN, B.; GRUISSEM, W.; JONES, R. Biochemistry \& Molecular Biology of Plants. EUA: American Society of Plant Biologists, 2002.1408 p.

BURRIS, R. H. Nitrogenases. Journal of Biological Chemistry, v. 266; p. 9339-9342, 1991.

CAVALCANTE, J. J. et al. Members of the ethylene signalling pathway are regulated in sugarcane during the association with nitrogen-fixing endophytic bacteria. Journal of Experimental Botany, v. 58, p. 673-686, 2007.

CHEN, Y. F.; ETHERIDGE, N.; SCHALLER, G. E. Ethylene signal transduction. Annals 
of Botany, v. 95, p. 901-915, 2005.

CHIMETTO, L. A. et al. Vibrios dominate as culturable nitrogen-fixing bacteria of the Brazilian coral Mussismilia hispida. Systematic and Applied Microbiology, v. 31, p. 312-319, 2008.

CHRISTIANSEN, J.; SEEFELDT, L. C.; DEAN, D. R. Competitive substrate and inhibitor interactions at the physiologically relevant active site of nitrogenase. Journal of Biological Chemistry, v. 275, p. 36104-36107, 2000.

COMPANHIA NACIONAL DE ABASTECIMENTO. Perfil econômico do setor canavieiro nacional. Brasília: Confederação da agricultura e pecuária do Brasil, 2010. Disponível em: http://www.cna.org.br/Cana-de-acucar/TextoPrincipal.htm. Acesso em: 1 ago. 2010.

COMPANT S. et al. Endophytic colonization of Vitis vinifera L. by plant growth promoting bacterium Burkholderia sp. strain PsJN, Applied Environmental Microbiology, v. 71, p. 1685-1693, 2005.

COMPANT S. et al. Endophytic colonization of Vitis vinifera L. by Burkholderia phytofirmans strain PsJN: from the rhizosphere to inflorescence tissues, FEMS Microbiology Ecology, v. 63, p. 84-93, 2008.

CORREA, J. D.; BARRIOS, M. L.; GALDONA, R. P. Screening for plant growth-promoting rhzobacteria in Chamaecytisus proliferus (tagasaste), a forage tree-shrub legume endemic to the Canary Islands. Plant and Soil, v. 266, p. 75-84, 2004.

COSTACURTA, A.; VANDERLEYDEN, J. Synthesis of phytohormones by plantassociated bacteria. Critical Reviews in Microbiology, v. 21, p. 1-18, 1995.

CROCOMO, O. J.; SILVEIRA, J. A. G.; ALEJO, A. P. Formas nitrogenadas e metabolismo de açúcares e crescimento em cana-de-açúcar (Saccharum sp.). In: CONGRESSO NACIONAL DA SOCIEDADE DOS TÉCNICOS AÇUCAREIROS E ALCOOEIROS DO BRASIL, 1. 1981, Rio de Janeiro. Anais... Rio de Janeiro: Sociedade dos Técnicos Açucareiros e Alcooeiros do Brasil, 1981. p. 282-304.

DE SALAMONE, I. E. G.; HYNES, R. K.; NELSON, L. M. Cytokinin production by plant growth-promoting rhizobacteria and selected mutants. Canadian Journal of Microbiology, v. 47, p. 404-411, 2001.

DELÉTOILE, A. et al. Phylogeny and identification of Pantoea Species and typing of Pantoea agglomerans strains by multilocus gene sequencing. Journal of Clinical Microbiology, v. 47, p. 300-310, 2009.

DEN BOER, B. G. W.; MURRAY, J. A. H. Triggering the cell cicle in plants. Trends in Cell Biology, v. 10, p. 245-250, 2000. 
DILWORTH, M. J. Assay methods for products of nitrogenase action on substrates. In: SMITH, B. E.; RICHARDS, L. R.; NEWTON, W. E. (Eds) Catalysts for nitrogen fixation: Nitrogenases, relevant chemical models and commercial processes. Netherlands: Springer, 2004. p. 55-76.

DÖBEREINER, J.; BALDANI, V. L.; BALDANI, J. I. Como isolar e identificar e identificar bactérias diazotróficas de plantas não-leguminosas Brasília: Embrapa, 1995. $60 \mathrm{p}$.

DÖBEREINER, J. Biological Nitrogen Fixation in the tropics: social and economic contributions. Soil Biology and Biochemistry, v. 29, p. 771-774, 1997.

DOS REIS JR, F. B. Ocorrência de bactérias diazotróficas em diferentes genótipos de cana-de-açúcar. Pesquisa Agropecuaria Brasileira, v. 35, p. 985-994, 2000.

DRINKWATER, L. E. et al. Fundamental differences between conventional and organic tomato agroecosystems in California. Ecological Applications, v. 5, p. 1098-1112, 1995.

DULIAART, J. The bioproduction of indole-3-acetic acid and related compound inroot nodules and roots of Lupinus lateus L. and by its rhizobial symbiont. Acta Botanica Neerlandica, v. 19, p. 573-615, 1970.

EGGELING, L.; SAHM, H. New ubiquitous translocators: amino acid export by Corynebacterium glutamicum and Escherichia coli. Archives of Microbiology, v. 180, p. 155-160, 2003.

ELBAHLOUL, Y. et al. Physiological conditions conducive to high cyanophycin content in biomass of Acinetobacter calcoaceticus, strain ADP1. Applied and Environmental Microbiology, v. 71, p. 858-866, 2005.

ELBELTAGY, A. et al. Endophytic colonization and in planta nitrogen fixation by a Herbaspirillum sp. isolated from wild rice species. Applied and Environmental Microbiology, v. 67 p. 5285-5293, 2001.

EL-KHAWAS, H.; ADACHI, K. Identification and quantification of auxins in culture media of Azospirillum and Klebsiella and their effect on rice roots. Biology and Fertility of Soils, v. 28, p. 377-381, 1999.

ENGELHARDT, M.; HUREK, T.; REINHOLD-HUREK, B. Preferential occurrence of diazotrophic endophytes, Azoarcus spp., in wild rice species and land races of Oryza sativa in comparison with modern races. Environmental Microbiology, v. 2, p. 131$141,2000$.

FENG, Y.; SHEN, D.; SONG, W. Rice endophyte Pantoea agglomerans YS19 promotes host plant growth and affects allocations of host photosynthates. Journal of Applied Microbiology, v. 100, p. 938-945, 2006. 
FRANCHE, C.; LINDSTROM, K; ELMERICH. C. Nitrogen-fixing bacteria associated with leguminous and non-leguminous plants. Plant and Soil, v. 321, p. 35-59, 2009.

FRANKENBERGER, W. T.; ARSHAD, M. Phytohormones in Soil: Microbial Production and Function, NY: Marcel Dekker, 1995. p. 503.

FUJISHIGE N. A. et al. Rhizobium common nod genes are required for biofilm formation. Molecular Microbiology, v. 67 p. 504-515, 2008.

FUKUDA, H.; OGAWA, T.; TANASE B. Ethylene production by micro-organisms. In: Rose, A. H. (Ed) Advances in Microbial Physiology, EUA: Academic Press, 1993. p. 275-342.

GADKARI, D. Superoxide-dependent nitrogenase. In: SMITH, B. E.; RICHARDS, L. R. \& NEWTON, W. E. (Eds) Catalysts for nitrogen fixation: Nitrogenases, relevant chemical models and commercial processes. Netherlands: Springer, 2004. p. 309-332.

GALSTON, A. W.; KAUR-SAWHNETY, R. Polyamines as endogenous growth regulators. In: DAVIES, P. J. (Ed.) Plant Hormones: Physiology, Biochemistry and Molecular Biology. NY: Springer, 1995. p. 158-178.

GLICK, B. R. The enhancement of plant growth by free-living bacteria. Canadian Journal of Microbiology, v. 41, p. 109-117, 1995.

GLICK, B. R. et al. Early development of Canola seedlings in the presence of the growth-promoting rhizobacterium Pseudomonas putida GR12-2. Soil Biology and Biochemistry, v. 29, p. 1233-1239, 1997.

GLICK, B. R. Modulation of plant ethylene levels by the bacterial enzyme ACC deaminase. FEMS Microbiology Letters, v. 251, p. 1-7, 2005.

GLICK, B. R. et al. Promotion of plant growth by ACC deaminase-producing soil bacteria. European Journal of Plant Pathology, v. 119, p. 329-339, 2007.

GORIS, J.; KERSTERS, K.; DE VOS, P. Polyamine distribution among authentic Pseudomonas and Azotobacteracea. Systematic and Applied Microbiology, v. 21, p. 285-290, 1998.

GRICHKO, V. P.; GLICK, B. R. Ethylene and flooding stress in plants. Plant physiology and Biochemistry, v. 39, p. 1-9, 2001.

GUO. B. et al. Cytonic acids A and B: novel tridepside inhibitors of hCMV protease from the endophytic fungus Cytonaema species. Journal of Natural Products, v. 63, p. 602604, 2000.

GUTIERREZ-MAÑERO, F. J. et al. The plant-growth-promoting rhizobacteria Bacillus 
pumilus and Bacillus licheniformis produce high amounts of physiologically active gibberellins. Physiologia Plantarum, v. 111, p. 206-211, 2001.

GYANESHWAR, P. et al. Endophytic colonization of rice by a diazotrophic strain of Serratia marcescens. Journal of Bacteriology, v. 183, p. 2634-2645, 2001.

HALDA-ALIJA, L. identification of indole-3-acetic acid producing freshwater wetland rhizosphere bacteria associated with Juncus effusus L. Canadian Journal of Microbiology, v. 49, p. 781-787, 2003.

HALES, B. J. Vanadium nitrogenase. In: SMITH B. E.; RICHARDS R.L.; NEWTON W.E. (Ed.) Catalysis for Nitrogen Fixation: Nitrogenases, Relevant Chemical models, and Commercial Processes. Netherlands, Klewer Academic Publishers, 2004. p. 255-279.

HALLMANN, J. et al. Bacterial endophytes in agricultural crops. Canadian Journal of Microbiology, v. 43, p. 895-914, 1997.

HALSALL, D. M. Inoculation of wheat straw to enhance lignocellulose breakdown and associated nitrogenase activity. Soil Biology and Biochemistry, v. 25, p. 419-429, 1993.

HAMMOND-KOSACK, K.; JONES, J. D. G. Responses to plant pathogens. In: BUCHANAN, B.; GRUISSEM, W.; JONES R. (Ed.) Biochemistry \& Molecular Biology of Plants. NY: American Society of Plant Biologists, 2000. 1408 p.

HAN, J. Characterization of a novel plant growth-promoting bacteria strain Delftia tsuruhatensis HR4 both as a diazotroph and a potential biocontrol agent against various pathogens. Systematic and Applied Microbiology, v. 28, p. 66-76, 2005.

HOLBEN, W. E. et al. GC fractionation enhances microbial community diversity assessment and detection of minority populations of bacteria by denaturing gradient gel electrophoresis. Applie and Environmental Microbiology, v. 70, p. 2263-2270, 2004.

HOPKINS, W. G. Introduction to Plant Physiology. 4. ed. England: John Wiley \& Sons, Inc. 2008. 528p.

HUANG, J. Ultrasstructure of bacterial penetration in plants. Annual Reviews of Phytpathology, v. 24, p. 141-157, 1986.

HUMBERT, R. P. The nutrition of sugarcane. In: HUMBERT, R. P. The growing of sugarcane. Amsterdam: Elsevier, 1968. p. 133-163.

HUNTER, W. J. Free and conjugated IAA content of legume root nodules. Plant Physiology, v. 80, p. 135, 1986.

HUREK, T. et al. Root 45-55.colonization and systemic spreading of Azoarcus sp strain BH72 in grasses. Journal of Bacteriology, v. 176, p. 1913-1923, 1994. 
IGARASHI, K.; KASHIWAGI, K. Polyamines: mysterious modulators of cellular functions. Biochemical and Biophysical Research Communications, v. 271, p. 559$564,2000$.

IÑIGUEZ, L. A.; DONG, Y.; TRIPLETT, E. W. Nitrogen fixation in wheat provided by Klebsiella pneumoniae 342 . Molecular Plant Microbe Interactions, v. 17, p. 10781085, 2004.

JAMES, E. K. et al. Infection of sugar cane by the nitrogen-fixing bacterium Acetobacter diazotrophicus. Journal of Experimental Botany, v. 45, p. 757-766, 1994.

JAMES, E.K.; OLIVARES, F. L. Infection and colonization of sugar cane and other graminaceous plants by endophytic diazotrophs. Critical Reviews in Plant Sciences, v. 17, p. $77-119,1997$.

JAMES E.K. et al. Infection and colonization of rice seedlings by the plant growthpromoting bacterium Herbaspirillum seropedicae Z67. Molecular Plant Microbe Interactions, v. 15, p. 894-906, 2002.

JUCKSCH, I.; MENDONÇA, E. S.; SANTOS, R. H. S. Agricultura alternativa, além de uma opção. Boletim Informativo da Sociedade Brasileira de Ciência do Solo, v. 25, p. 9-13, 2000.

KARTHIKEYAN, M. et al. Endophytic Pseudomonas fluorescens Endo2 and Endo35 induce resistance in black gram (Vigna mungo L. Hepper) to the pathogen Macrophomina phaseolina. Journal of Plant Interactions, v. 1, p. 135-143, 2005.

KAYS, S. J.; PAULL, R. E. Postharvest Biology. EUA: Exon Press, 2004. 568 p.

KAVANAGH, E. P.; HILL, S. Oxygen inhibition of nitrogenase activity in Klebsiella pneumoniae. Journal of General Microbiology, v. 139, p. 1307-1314, 1993.

KIM, J.; REES, D. C. Nitrogenase and biological nitrogen fixation. Biochemistry, v. 33, p. 379-397, 1994.

KIM, C. H.; NEWTON, W. E.; DEAN. D. R. Role of the MoFe protein alfa-subunity histidine-195 residue in FeMo-cofactor binding and nitrogenase catalysis. Biochemistry, v. 34, p. 2798-2808, 1995.

KLOEPPER, J. W. Emergence-promoting rhizobacteria: description and implications for agriculture. In: SWINBURNE, T.R. (Ed.) Iron, Siderophores and Plant Disease, NY: CRC Press, 1986. p. 155-164.

KOGA, J.; ADACHI, T.; Hidaka, H. Molecular cloning of the gene for indolepyruvate decarboxylase from Enterobacter cloacae. Molecular and General Genetics, v. 226, p. 10-16, 1991. 
KOJIMA, K. Changes of abscisic acid, indole-3-acetic acid and giberelin-like substances in the flowers and development fruilets of citrus cultivar 'Hyuganatsu'. Science Horticulture, v. 65, p. 263-272, 1996.

KRAMER, S. B. et al. Reduced nitrate leaching and enhanced denitrifier activity and efficiency in organically fertilized soils. PNAS, v. 103, p. 4522-4527, 2006.

KREUGER, J.; PETERSON, M.; LUNGREN, E. Agricultural inputs of pesticide residues to stream and pond sediments in a small catchment in southern Sweden. Bulletin of Environmental Contamination Toxicollogy, v. 62, p. 55-62, 1999.

KUKLINSKI-SOBRAL, J. et al. Isolation and characterization of soybean-associated bacteria and their potential for plant growth promotion. Environmental Microbiology, $v$. 12, p. 1244-1251, 2004.

KUMAR, V. et al. An alternative agriculture system is defined by a distinct expression profile of selected gene transcripts and proteins. PNAS, v. 101, p. 10535-10540, 2004.

KUMAR, S.; PANDEY, P; MAHESHWARI, D.K. Reduction in dose of chemical fertilizers and growth enhancement of sesame (Sesamum indicum L.) with application of rhizospheric competent Pseudomonas aeruginosa LES4. European Journal of Soil Biology, v. 45, p. 334-340, 2009.

KUSANO, T. Polyamines: Essential factors for growth and survival. Planta, v. 228, p. 367-381, 2008.

LEITA, L. et al. Influence of inorganic and organic fertilization on soil microbial biomass, metabolic quotient and heavy metal bioavailability. Biology and Fertility of Soils, v. 28, p. 371-376, 1999.

LI, Y.; SOLOMON, S. Ethephon: A versatile growth regulator for sugar cane industry. Sugar Tech, v. 5, p. 213-223, 2003.

LIBA, C. M. et al. Nitrogen-fixing chemoorganotrophic bacteria isolated from cyanobacteria-deprived lichens and their ability to solubilise phosphate and to release amino acids and phytormones. Journal of Applied Microbiology, v. 101, p. 1076-1086, 2006.

LIN, Z. et al. Origins and evolution of the recA/RAD51 gene family: Evidence for ancient gene duplication and endosymbiotic gene transfer. PNAS, v. 103, p. 10328-10333, 2006.

LOIRET, F. G. et al. Inoculation of sugarcane with Pantoea sp. increases amino acid contents in shoot tissues; serine, alanine, glutamine and asparagine permit concomitantly ammonium excretion and nitrogenase activity of the bacterium. Journal of Plant Physiology, v. 166, p. 1152-1161, 2009. 
MA, Y.; RAJKUMAR, M.; FREITAS, H. Improvement of plant growth and nickel uptake by nickel resistant-plant-growth promoting bacteria. Journal of Hazardous Materials, v. 166, p. 1154-1161, 2009a.

MA, Y.; RAJKUMAR, M.; FREITAS, H. Inoculation of plant growth promoting bacterium Achromobacter xylosoxidans strain Ax10 for the improvement of copper phytoextraction by Brassica juncea. Journal of Environmental Manegement, v. 90, p. 831-837, 2009b.

MADER, P. et al. Soil fertility and biodiversity in organic farming, Science, v. 296 p. 1694-1697, 2002.

MAGNANI, G. S. et al. Diversity of endophytic bacteria in Brazilian sugarcane. Genetics and Molecular Research, v. 9, p. 250-258, 2010.

MARINO, R. et al. Ecological constraints on planktonic nitrogen fixation in saline estuaries. I. Nutrient and trophic controls. Marine Ecology Progress Series, v. 309, p. 25-39, 2006.

MAYAK, S.; TIROSH, T.; GLICK, B.R. Effect of wild-type and mutant plant growthpromoting rhizibacteria on the rooting of mung bean cuttings. Journal of Plant Growth Regulation, v. 18, p. 49-53, 1999.

MEHBOOB, I.; NAVEED, M; ZAHIR. Z. A. Rhizobial association with non-legumes: mechanisms and applications. Current Reviews in Plant Sciences, v. 28, p. 432-456, 2009.

MEHNAZ, S. et al. Growth promoting effects of corn (Zea mays) bacterial isolates under greenhouse and field conditions. Soil Biology and Biochemistry, doi:10.1016/j.soilbio.2010.07.003. In Press.

MENDES, R. et al. Diversity of Cultivated Endophytic Bacteria from Sugarcane: Genetic and biochemical characterization of Burkholderia cepacia complex isolates. Applied and Environmental Microbiology, v. 73, p. 7259-7267, 2007.

MILLER, C. M. et al. Ecomycins, unique antimycotics from Pseudomonas viridiflava. Journal of Applied Microbiology, v. 84, p. 937-44, 1998.

MIRZA, M. S. et al. Isolation, partial characterization, and the effect of plant growthpromoting bacteria (PGPB) on micro-propagated sugarcane in vitro. Plant and Soil, v. 237, p. 47-54, 2001.

MIYASAKA, N. R. S. et al. During stationary phase, Beijerinkia derxii shows nitrogenase activity concomitant with the release and accumulation of nitrogenated substances. Microbiological Research, v. 158, p. 309-315, 2003.

MONTAÑEZ, A. et al. Biological nitrogen fixation in maize (Zea mays L.) by $15 \mathrm{~N}$ isotope-dilution and identification of associated culturable diazotrophs Biology and 
Fertility of Soils, v. 45, p. 253-263, 2009.

MORAN, N. A. Symbiosis as an adaptive process and source of phenotypic complexity. PNAS, v. 104, p. 8627-8633, 2007

MURASHIGE, T.; SKOOG, F. A. Revised medium for rapid growth and bioassay with Tobaco tissue cultures. Physiologia Plantarum, v. 15, p. 487-497, 1962.

MUTHUKUMARASAMY, R.; REVATHI, G. Diazotrophic associations in sugar cane cultivation in South India. Tropical Agriculture, v. 76, p. 171-178, 1999.

MUTHUKUMARASAMY, R.; REVATHI, G.; LAKSHMINARASIMHAN, C. Influence of N fertilization on the isolation of Acetobacter diazotrophicus and Herbaspirillum spp. from indian sugarcane varieties. Biology and Fertility of Soils, v. 37, p. 157-164, 1999.

NASER, S. M. et al. Application of multilocus sequence analysis (MLSA) for rapid identification of Enterococcus species based on rpoA and pheS genes. Microbiology, v. 151, p. 2141-2150, 2005.

NIKOGOSIAN, V. G. Comparative evaliation of the nitrogen fixing activity of an Azotobacter using the acetylene method and on the basis of total nitrogen Mikrobiologiya, v. 52, p. 848-850, 1983.

OKON, Y.; HEYTLER, P. G.; HARDY, R. W. F. $\mathrm{N}_{2}$ fixation by Azospirillum brasilense and its incorporation into host Setaria italica. Applied Environmental Microbiology, v. 46, p. 694-697, 1983.

OLIVEIRA, A.L.M. et al. The effect of inoculating endophytic $\mathrm{N}_{2}$-fixing bacteria on micropropagated sugarcane plants. Plant and Soil, v. 242, p. 205-215, 2002.

PAAUW A., M. et al. Identification of resistance and virulence factors in an epidemic Enterobacter hormaechei outbreak strain. Microbiology, v. 155. P. 14781488, 2009.

PAL, K. K. Suppression of maize root diseases caused by Macrophomina phaseolina, Fusarium moniliforme and Fusarium graminearum by plant growth promoting rhizobacteria. Microbiological Research, v. 156, p. 209-223, 2001.

PARIONA-LLANOS, R. Isolamento de bactérias endofíticas fixadoras de nitrogênio de cana-de-açuacar submetida a adubação orgânica ou fertilizada com $\mathrm{N}$-mineral ou sem adubação: comparação quantitativa e da presença de atividade nitrato redutase assimilatória. Dissertação (Mestrado em Microbiologia) - Instituto de Ciências Biomédicas, Universidade de São Paulo, São Paulo, 2007. 93 p.

PATI, B. R. ; SENGUPTA, S. ; CHANDRA, A. K. Studies of the amino acids released by phyllosphere diazotrophic bacteria. Microbiological Research, v. 149, p. 287-290, 1994. 
PATTEN, C. L.; Glick. B. R. Bacterial biosynthesis of indole-3-acetic acid. Canadian Journal of Microbiology, v. 42, p. 207-220, 1996.

PEDRAZA, R. O. Aromatic amino acid aminotransferase activity and indole-3-acetic acid production by associative nitrogen-fixing bacteria. FEMS Microbiol Letters, v. 233, p. 15-21, 2006.

PERSELLO-CARTIEAUX, F.; NUSSAUME, L.; ROBAGLIA, C. Tales from the underground: molecular plant-rhizobacteria interactions. Plant Cell Environment, v. 26, p. 189-199, 2003.

PIERIK, R. et al. The Janus face of ethylene: growth inhibition and stimulation. TRENDS in Plant Sciences, v. 11, p. 176-183, 2006.

PIMENTEL, J. P. et al. Dinitrogen fixation and infection of grass leaves by Pseudomonas rubrisubalbicans and Herbaspirillum seropedicae. Developments in Plant and Soil Sciences, v. 48, p. 225-229, 1991.

PIRTTILA, A. M. et al. Bud endophytes of Scots pine produce adenine derivatives and other compounds that affect morphology and mitigate browning of callus cultures.

Physiologia Plantarum, v. 121, p. 305-312, 2004.

PORRA RJ. Labelling of chlorophylls and precursors by [2-14C] glycine and 2-[1-14C] oxoglutarate in Rhodopseudomonas spheroides and Zea mays. Resolution of the C5 and Shemin pathways of 5-aminolaevulinate biosynthesis by thin-layer radiochromatography. European Journal of Biochemistry, v. 156, p. 111-121, 1986.

PRAKAMHANG, J. et al. The communities of endophytic diazotrophic bacteria in cultivated rice (Oryza sativa L.). Applied Soil Ecology, v. 42, p. 141-149, 2009.

REES, D. C.; HOWARD, J. B. Nitrogenase: standing in the crossroads. Current Opinion in Chemical Biology, v. 4, p. 559-566, 2000.

REGANOLD, J. P.; Elliott, L. F.; Unger, Y. L. Long-term effects of organic and conventional farming on soil erosion. Nature, v. 330, p. 370-372, 1987.

REINHOLD-HUREK, B.; HUREK, T. Life in grasses: diazotrophic endophytes. Trends Microbiology, v. 6, p. 139-143, 1998.

REINHOLD-HUREK, B. et al. An endoglucanase is involved in infection of rice roots by the not-cellulose-metabolizing endophyte Azoarcus sp strain BH72, Molecular Plant Microbe Interactions, v. 19, p. 181-188, 2006.

RENWICK, A. R.; CAMPBELL, A.; COE, S. Assessment of in vivo screening systems for potential biocontrol agents of Gaeumannomyces graminis. Plant Physiology, v. 40, p. 524-532, 1991. 
RIBBE, M.; GADKARI, D.; MEYER O. $\mathrm{N}_{2}$ fixation by Streptomyces thermoautotrophicus involves a molybdenium-dinitrogenase and a manganese-superoxide oxidoreductase that couple $\mathrm{N}_{2}$ reduction to the oxidation of superoxide produced from $\mathrm{O}_{2}$ a molybdenium-CO dehydrogenase. Journal of Biological Chemistry, v. 272, p. 2662726633, 1997.

RIVAS, R. et al. Multilocus sequence analysis of the genus Bradyrhizobium. Systematic and Applied Microbiology, v. 32, p. 101-110, 2009.

RODRIGUEZ, H.; FRAGA, R. Phosphate solubilizing bacteria and their role in plant growth promotion. Biotechnology Advances, v. 17, p. 319-339, 1999.

ROESCH, L. F. W. et al. Biodiversity of diazotrophic bacteria within the soil, root and stem of field-grown maize. Plant and Soil, v. 302, p. 91-104, 2008.

ROSENBLUETH, M.; MARTINEZ-ROMERO E. Bacterial endophytes and their interactions with hosts. Molecular Plant Microbe Interactions, v. 19, p. 827-837, 2006.

RUSCHEL, A. P.; VOSE, P. B., Biological nitrogen fixation is sugar cane. In: SUBBARAO, N. S. (Ed.) Current developments in Biological Nitrogen Fixation. London: Edward Arnold 1984. p. 219-235.

RYAN, R. P. et al. Dowling Bacterial endophytes: recent developments and applications. FEMS Microbiology Letters, v. 278, p. 1-9, 2008.

SAIKIA, V. P.; JAIN, V. Biological nitrogen fixation in non legumes: an achievable target or a dogma? Current Science, v. 92, p. 317-322, 2007.

SANDHIYA, G. S. et al. Endophytic colonization and in planta nitrogen fixation by a diazotrophic Serratia sp. in rice. Indian Journal of Experimental Biology, v. 43, p. 802-807, 2005.

SARODE, P. D. et al. Siderophoregenic Acinetobacter calcoaceticus isolated from wheat rhizosphere with strong PGPR activity. Malaysian Journal of Microbiology, v. 5, p. 612, 2009.

SCOTT, D. J.; DEAN, D. R.; NEWTON, W. E. Nitrogenase-catalyzed ethane production and CO-sensitive hydrogen evolution from MoFe proteins having amino acid substitutions in an alpha-subunit FeMo cofactor-binding domain. Journal of Biological Chemistry, v. 267, p. 20002-20010, 1992.

SELVAKUMAR, S. et al. Isolation and characterization of nonrhizobial plant growth promoting bacteria from nodules of kudzu (Pueraria thunbergiana) and their effect on wheat seedling growth. Current Microbiology, v. 56, p. 134-139, 2007.

SHULZ, B.; BOYLE, C. What are endophytes? Microbial Root Endophytes, v. 9, p. 1- 
13, 2006.

SILVEIRA, V. et al. Effect of plant growth regulators on the cellular growth and levels of intracellular protein, starch and polyamines in embriogenic suspention cultures of Pinus taeda. Plant Cell, Tissue and Organ Culture, v. 76, p. 53-60, 2004.

SOGE, O. O.; ADENIYI, B. A.; ROBERTS, M. C. New antibiotic resistance genes associated with CTX-M plasmids from uropathogenic Nigerian Klebsiella pneumoniae. Journal Antimicrobial Chemotherapy, v. 58, p. 1048-1053, 2006.

SPAEPEN, S.; VANDERLEYDEN, J.; REMANS, R. Indole-3-acetic acid in microbial and microorganism-plant signaling. FEMS Microbiology Reviews, v. 31, p. 425-448, 2007.

SPAEPEN, S. et al. Effects of Azospirillum brasilense indole-3-acetic acid production on inoculated wheat plants. Plant and Soil, v. 312, p. 15-23, 2008.

SPRENT, J. I. ; DE FARIA, S. M. Mechanisms of infection of plants by nitrogen-fixing organisms. Plant and Soil, v. 110, p. 157-165, 1988.

STACKEBRANDT E.; EBERS, J. Taxonomic parameters revisited: tarnished gold standards Microbiology Today, v. Nov, p. 152-155, 2006.

STEENHOUDT, O.; VANDERLEYDEN, J. Azospirillum, a free-living nitrogen-fixing bacterium closely associated with grasses: genetic, biochemical and ecological aspects. FEMS Microbiolology Reviews, v. 24, p. 487-506, 2000.

STROBEL, G. A. et al. Cryptocandin, a potent antimycotic from the endophytic fungus Cryptosporiopsis cf. quercina. Microbiology, v. 145, p. 1919-26, 1999.

STROBEL, G. A. et al. Isopestacin, an isobenzofuranone from Pestalotiopsis microspora, possessing antifungal and antioxidant activities. Phytochemistry, v. 60, p. 179-83, 2002

STROBEL, G. A.; DAISY, B. Bioprospecting for microbial endophytes and their natural products. Microbiological and Molecular Biology Reviews, v. 67, p. 491-502, 2003.

STRZELCZYK, E.; KAMPERT, M.; LI, C. Y. Cytocinin-like substances and ethylene production by Azospirillum in media with different carbon sources. Microbiological Research, v. 149, p. 55-60, 1994.

STURZ, A. V. The role of endophityc bacteria during seed piece decay and potato tuberization. Plant and Soil, v. 175, p. 257-263, 1995.

SUN L. et al. Endophytic bacterial diversity in rice (Oryza sativa L.) roots estimated by 16S rDNA sequence analysis. Microbial Ecology, v. 55, p. 415-424, 2007.

TABACCHIONE, S. et al. Characteristics of two rhizosphere isolates of Pseudomonas 
cepacia and their potential plant-growth-promotion activity. Microbiological Releases, v. 2, p. 161-168, 1993.

TAIZ, L.; ZEIGER, E. Plant Physiology. 3. ed. Sunderland: Sinauer Associates, 2002. $690 \mathrm{p}$.

TAN, R. X.; ZOU, W. X. Endophytes: a rich source of functional metabolites. Natural Products Reports, v. 18, p. 448-59, 2001.

THULER, D. S. et al. Plant growth regulators and amino acids released by Azospirillum sp. in chemically defined media. Letters in Applied Microbiology, v. 37, p. 174-178, $2003 a$.

THULER, D. S. et al. Beijerinckia derxii releases plant growth regulators and amino acids in synthetic media independent of nitrogenase activity. Journal of Applied Microbiology, v. 95, p. 799-806, 2003b.

TIEN, T. M.; GASKINS, M. H.; HUBBELL, D. H. Plant growth substances produced by Azospirillum brasilense and their effect on the growth of pearl millet. Applied Environmental Microbiology, v. 37, p. 1016-1024, 1979.

TILAK, K. V. B. R. et al. Diversity of plant growth and soil health supporting bacteria. Current Science, v. 89, p. 136-150, 2005.

TORRES-RUBIO, M. G. et al. Isolation of enterobacteria, Azotobacter sp. and Pseudomonas sp., producers of indole-3-acetic acid and siderophores, from Colombian rice rhizosphere. Revista Latinoamericana de Microbiologia, v. 42, p.171-176, 2000.

TOYODA, $K$. et al. Expression of the gapA gene encoding glyceraldehyde-3-phosphate dehydrogenase of Corynebacterium glutamicum is regulated by the global regulator SugR. Applied Microbiology and Biotechnology, v. 81, p. 291-301, 2008.

TUOMI, T.; LAAKSO, S.; ROSENQVIST, H. Plant hormones in fungi and bacteria from malting barley. Journal of the Institute of Brewing, v. 101, p. 351-357, 1995.

URQUIAGA, S.; CRUZ, K. H. S.; BODDEY, R. M. Contribution of nitrogen fixation to sugar cane: Nitrogen-15 and nitrogen balance estimates. Soil Science Society of America Journal, v. 56, p. 105-114, 1992.

VAN BERKUM, P.; ELIA, P.; EARDLY B. D. Multilocus Sequence typing as an approach for population analysis of medicago-nodulating rhizobia. Journal of Bacteriology, $v$. 188, p. 5570-5577, 2006.

VERMA, S. C.; LAHDA, J. K.; TRIPATHI A. K. Evaluation of plant growth promoting and colonization ability of endophytic diazotrophs from deep water rice. Journal of Bacteriology, v. 91, p. 127-141, 2001. 
VIKRAM, A. et al. Production of plant growth promoting substances by phosphate solubilizing bacteria isolated from vertisols. Journal of Plant Sciences, v. 2, p. 326333, 2007.

VITOUSEK, P. M.et al.. Human alteration of the global nitrogen cycle: causes and consequences. Ecological Applications, v. 7, p. 737-750, 1997.

WALLACE, H. M.; FRASER, A. V.; HUGHES A. A perspective of polyamine metabolism. Biochemical Journal, v. 376, p. 1-14, 2003.

WANG, E. T. Diverse endophytic bacteria isolated from a leguminous tree Conzattia multixora grown in Mexico. Archives of Microbiology, v. 186, p. 251-259, 2006.

WEISBURG, W. G. et al. 16S ribosomal DNA amplification for phylogenetic study. Journal of Bacteriology, v. 173, p. 697-703, 1991.

WEYENS, N. et al. Exploiting plant-microbe partnerships to improve biomass production and remediation. Trends in Biotechnology, v. 27, p. 591-598, 2009.

WIENER, J. et al. Multiple Antibiotic-Resistant Klebsiella and Escherichia coli in Nursing Homes. JAMA, v. 281, p. 517-523, 1999.

WIMBERLY B. T. Structure of the $30 \mathrm{~S}$ ribosomal subunit. Nature, v. 407 , p. 327-339, 2000.

ZAPATA, P. J. et al. Changes in free polyamine concentration induced by salt stress in seedlings of different species. Plant Growth Regulation, v. 56, p. 167-177, 2008.

ZEIGLER, D. R. Gene sequences usefull for predicting relatedness of whole genomes in bacteria. International Journal of Systematic and Evolutionary Microbiology, v. 53, p. 1893-1900, 2003.

ZHANG, L.; XU, Z. Assessing bacterial diversity in soil: a brief review. Journal of Soils and Sediments, v.8, p. 379-388, 2008.

ZHIYUAN, T.; HUREK, T.; REINHOLD-HUREK, B. Effect of $\mathrm{N}$-fertilization, plant genotype and environmental conditions on nifH gene pools in roots of rice. Environmental Microbiology, v. 5p. 1009-1015, 2003.

ZIMMER, W.; BOTHE H. The phytohormonal interactions between Azospirillum and wheat. Plant and Soil, v. 110, p. 239-247, 1988. 


\section{ANEXO A \\ ARTIGO PUBLICADO}

LIBA, C. M.; FERRARA, F. I. S.; MANFIO G. P.; FANTINATTI-GARBOGGINI, F.; ALBUQUERQUE, R. C.; PAVAN, C.; RAMOS, P. L.; MOREIRA-FILHO, C. A.; BARBOSA $H$. R. Nitrogen-fixing chemoorganotrophic bacteria isolated from cyanobacteria-deprived lichens and their ability to solubilise phosphate and to release amino acids and phytormones. Journal of Applied Microbiology, v. 101, p. 1076-1086, 2006. 


\section{ANEXO B ARTIGOS ENVIADOS PARA PUBLICAÇÃO}

Artigo aceito

PARIONA-LLANOS, R.; FERRARA, F. I. S.; BARBOSA, H. R. Influence of organic fertilization on the number of culturable diazotrophic endophytic bacteria isolated from sugarcane. European Journal of Soil Biology, 2010.

Artigo em revisão

FERRARA, F. I. S.; FLOH, E. I. S.; BARBOSA, H. R. Herbaspirillum: new features related to plant growth. Archives of Microbiology.

Artigo submetido

OLIVEIRA, Z. M.; FERRARA, F. I. S.; BARBOSA, H. R. Diazotrophic bacteriaisolated from sugarcane are able to release amino acids in synthetic culture medium. Biology and Fertility of Soils. 